INEL-95/0505

\title{
Characteristics and Origin of Earth-Mounds on the Eastern Snake River Plain, Idaho
}

\author{
J. A. Tullis
}

Published September 1995

Idaho National Engineering Laboratory

Lockheed Martin Idaho Technologies

Idaho Falls, Idaho $\mathbf{8 3 4 1 5}$

Prepared for the

U.S. Department of Energy

Assistant Secretary for Environmental Management

Under DOE Idaho Operations Office

Contract DE-AC07-94ID13223 


\section{ABSTRACT}

Earth-mounds are common features on the Eastern Snake River Plain, Idaho. The mounds are typically round or oval in plan view, $<0.5 \mathrm{~m}$ in height, and from 8 to $14 \mathrm{~m}$ in diameter. They are found on flat and sloped surfaces, and appear less frequently in lowland areas. The mounds have formed on deposits of multiple sedimentary environments. Those studied included alluvial gravel terraces along the Big Lost River (late Pleistocene/early Holocene age), alluvial fan segments on the flanks of the Lost River Range (Bull Lake and Pinedale age equivalents), and loess/slopewash sediments overlying basalt flows.

Backhoe trenches were dug to allow characterization of stratigraphy and soil development. Each mound has features unique to the depositional and pedogenic history of the site; however, there are common elements to all mounds that are linked to the history of mound formation. Each mound has a "floor" of a sediment or basement rock of significantly different hydraulic conductivity than the overlying sediment. These paleosurfaces are overlain by finer-grained sediments, typically loess or flood-overbank deposits.

Mounds formed in environments where a sufficient thickness of fine-grained sediment held pore water in a system open to the migration to a freezing front. Heaving of the sediment occurred by the growth of ice lenses. Mound formation occurred at the end of the Late Pleistocene or early in the Holocene, and was followed by pedogenesis. Soils in the mounds were subsequently altered by bioturbation, buried by eolian deposition, and eroded by slopewash runoff. These secondary processes played a significant role in maintaining or increasing the mound/ intermound relief.

\section{DISCLAIMER}

\footnotetext{
This report was prepared as an account of work sponsored by an agency of the United States Government. Neither the United States Government nor any agency thereof, nor any of their employees, makes any warranty, express or implied, or assumes any legal liability or responsibility for the accuracy, completeness, or usefulness of any information, apparatus, product, or process disclosed, or represents that its use would not infringe privately owned rights. Reference herein to any specific commercial product, process, or service by trade name, trademark, manufacturer, or otherwise does not necessarily constitute or imply its endorsement, recommendation, or favoring by the United States Government or any agency thereof. The views and opinions of authors expressed herein do not necessarily state or reflect those of the United States Government or any agency thereof.
} 


\section{DISCLAIMER}

Portions of this document may be illegible in electronic image products. Images are produced from the best available original document. 


\section{CONTENTS}

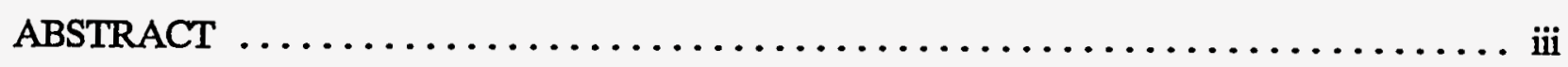

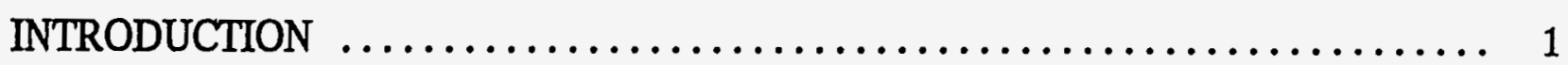

BACKGROUND $\ldots \ldots \ldots \ldots \ldots \ldots \ldots \ldots \ldots \ldots \ldots \ldots \ldots \ldots \ldots \ldots \ldots \ldots$

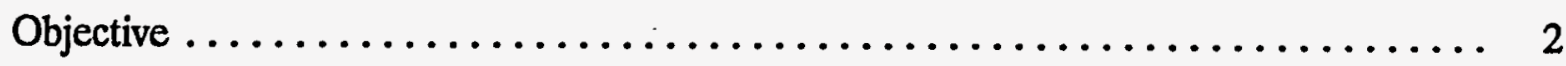

Theories of Mound Origin $\ldots \ldots \ldots \ldots \ldots \ldots \ldots \ldots \ldots \ldots \ldots \ldots, 2$

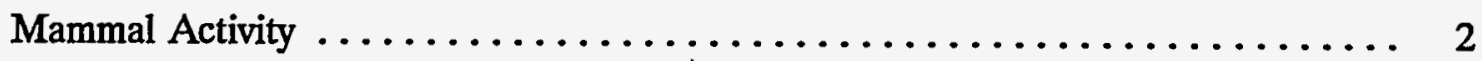

Erosional Hypotheses $\ldots \ldots \ldots \ldots \ldots \ldots \ldots \ldots \ldots \ldots \ldots \ldots \ldots \ldots \ldots \ldots \ldots, 3$

Depositional Hypotheses $\ldots \ldots \ldots \ldots \ldots \ldots \ldots \ldots \ldots \ldots \ldots \ldots \ldots \ldots, \quad 3$

Seismic Shaking $\ldots \ldots \ldots \ldots \ldots \ldots \ldots \ldots \ldots \ldots \ldots \ldots \ldots \ldots \ldots \ldots \ldots, 3$

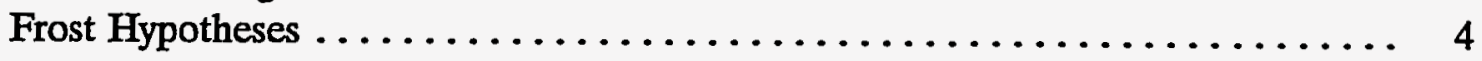

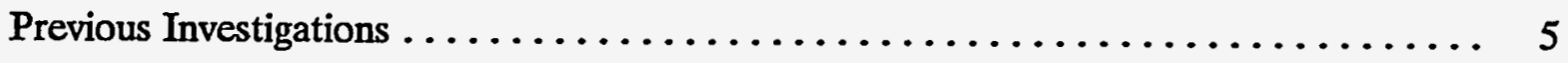

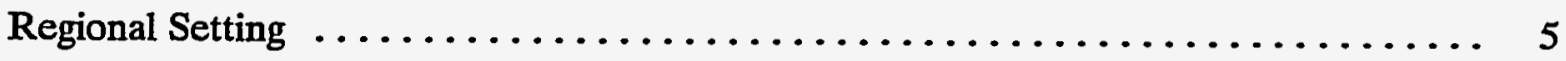

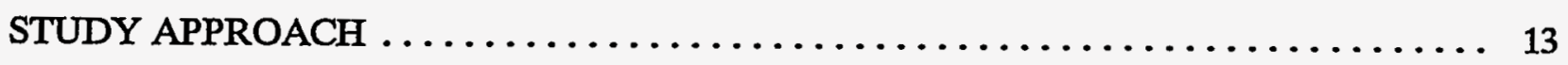

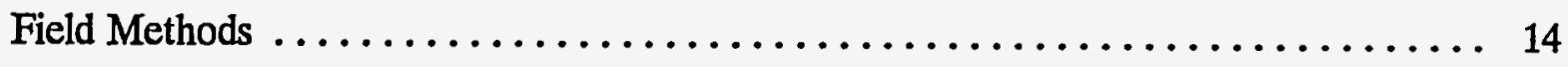

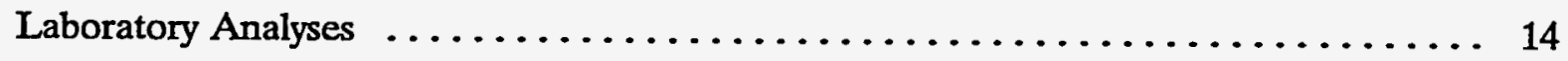

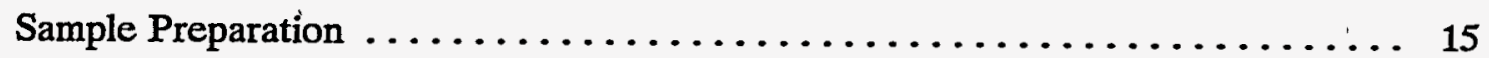

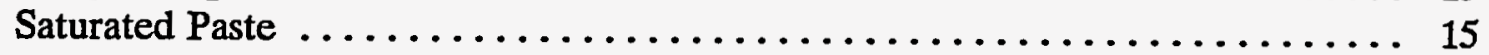

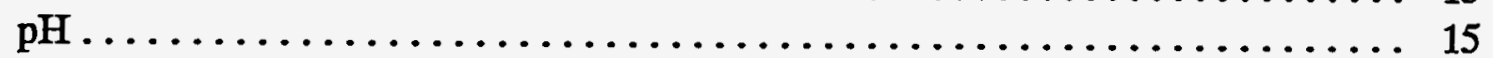

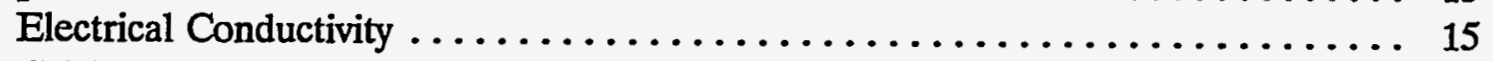

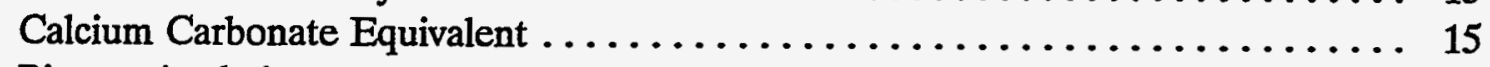

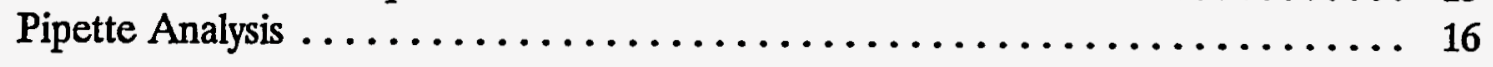

SITE AND TRENCH DESCRIPTIONS $\ldots \ldots \ldots \ldots \ldots \ldots \ldots \ldots \ldots \ldots \ldots \ldots \ldots \ldots$

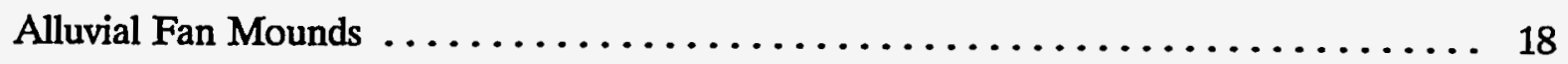

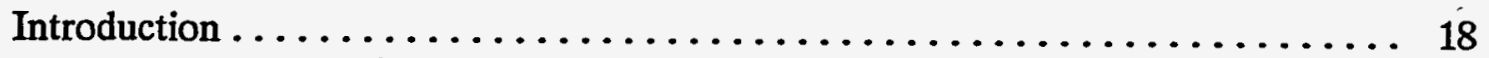

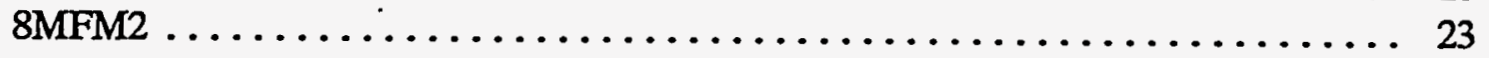

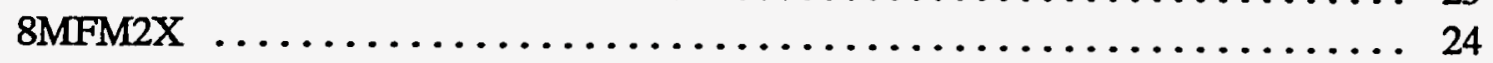

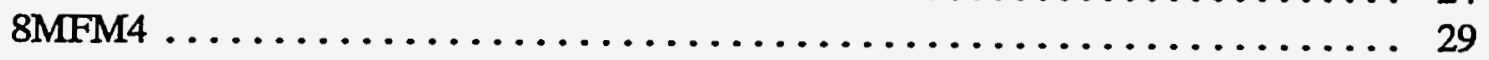

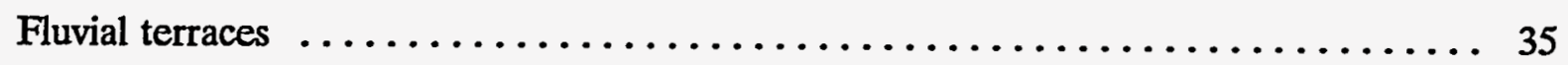

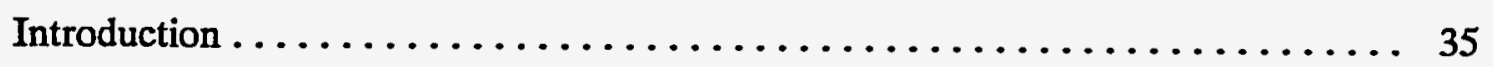




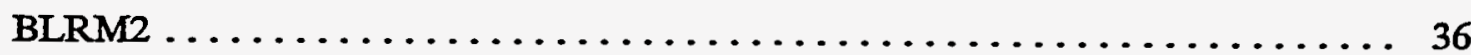

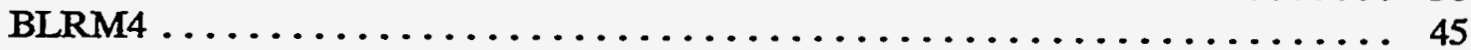

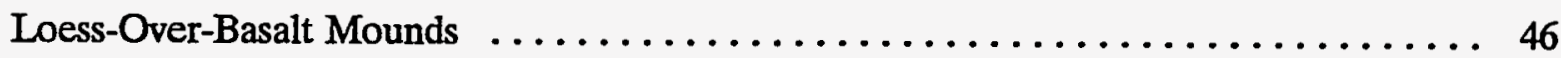

Introduction $\ldots \ldots \ldots \ldots \ldots \ldots \ldots \ldots \ldots \ldots \ldots \ldots \ldots \ldots \ldots \ldots \ldots \ldots \ldots$

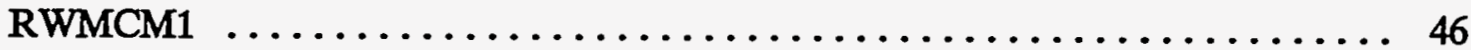

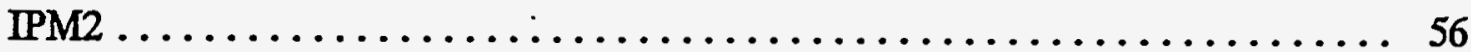

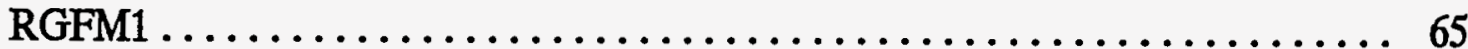

DISCUSSION $\ldots \ldots \ldots \ldots \ldots \ldots \ldots \ldots \ldots \ldots \ldots \ldots \ldots \ldots \ldots \ldots \ldots \ldots$

Regional Paleoclimate $\ldots \ldots \ldots \ldots \ldots \ldots \ldots \ldots \ldots \ldots \ldots \ldots \ldots \ldots$

Mound Physiography $\ldots \ldots \ldots \ldots \ldots \ldots \ldots \ldots \ldots \ldots \ldots \ldots \ldots \ldots \ldots \ldots$

Vegetation $\ldots \ldots \ldots \ldots \ldots \ldots \ldots \ldots \ldots \ldots \ldots \ldots \ldots \ldots \ldots \ldots \ldots \ldots \ldots \ldots$

Mound Floors $\ldots \ldots \ldots \ldots \ldots \ldots \ldots \ldots \ldots \ldots \ldots \ldots \ldots \ldots \ldots \ldots \ldots \ldots \ldots$

Stratigraphy $\ldots \ldots \ldots \ldots \ldots \ldots \ldots \ldots \ldots \ldots \ldots \ldots \ldots \ldots \ldots \ldots \ldots \ldots \ldots \ldots$

Pedogenesis $\ldots \ldots \ldots \ldots \ldots \ldots \ldots \ldots \ldots \ldots \ldots \ldots \ldots \ldots \ldots \ldots \ldots \ldots \ldots \ldots$

Mammal Activity $\ldots \ldots \ldots \ldots \ldots \ldots \ldots \ldots \ldots \ldots \ldots \ldots \ldots \ldots \ldots \ldots \ldots$

Secondary Processes $\ldots \ldots \ldots \ldots \ldots \ldots \ldots \ldots \ldots \ldots \ldots \ldots \ldots \ldots \ldots \ldots$

CONCLUSIONS $\ldots \ldots \ldots \ldots \ldots \ldots \ldots \ldots \ldots \ldots \ldots \ldots \ldots \ldots \ldots \ldots \ldots \ldots \ldots$

REFERENCES ................................. 86

Appendix A-Partial List of Mound Origin Research Since 1945 . . . . . . . . . . . . . A-1

Appendix B-Field and Laboratory Data $\ldots \ldots \ldots \ldots \ldots \ldots \ldots \ldots \ldots \ldots \ldots$ B-1

Appendix $\mathrm{C}-$ Site Location and Surficial Characteristics $\ldots \ldots \ldots \ldots \ldots \ldots \ldots \ldots \ldots$

\section{FIGURES}

1. Computer-generated, digital-topographic map showing the regional setting, and the contrast in relief between the ESRP, and the Basin and Range Mountains and Yellowstone Plateau

2. Generalized geologic map of the INEL area showing the distribution of basalt flows and thick sedimentary deposits 
3. Soil textural classes plotted on a triangular diagram. ................ 17

4. USGS 7.5 minute topographic map showing the location of 8MFM2 and 8MFM4 in relation to the Eight Mile Fan . . . . . . . . . . . . . . . . . . . . 19

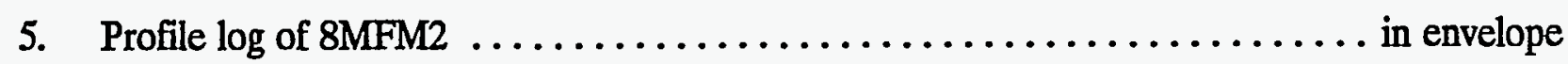

6. Profile $\log$ of $8 \mathrm{MFM} 4 \ldots \ldots \ldots \ldots \ldots \ldots \ldots \ldots \ldots \ldots \ldots \ldots$ in envelope

7. USGS 7.5 minute topographic map showing the location of BLRM2 and BLRM4 . . . 41

8. Profile $\log$ of BLRM2 $\ldots \ldots \ldots \ldots \ldots \ldots \ldots \ldots \ldots \ldots \ldots \ldots \ldots \ldots$ in envelope

9. Profile $\log$ of BLRM4 $\ldots \ldots \ldots \ldots \ldots \ldots \ldots \ldots \ldots \ldots \ldots \ldots \ldots$ in envelope

10. USGS 7.5 minute topographic map showing the location of RWMCM1 and IPM2 . . . 51

11. Profile log of $\mathrm{RWMCM} 1 \ldots \ldots \ldots \ldots \ldots \ldots \ldots \ldots \ldots \ldots \ldots \ldots \ldots \ldots$ in envelope

12. Profile $\log$ of IPM2 $\ldots \ldots \ldots \ldots \ldots \ldots \ldots \ldots \ldots \ldots \ldots \ldots \ldots \ldots \ldots \ldots \ldots$ in envelope

13. USGS 7.5 minute topographic map showing the location of RGFM1 $\ldots \ldots \ldots 7$

14. Profile $\log$ of RGFM1 $\ldots \ldots \ldots \ldots \ldots \ldots \ldots \ldots \ldots \ldots \ldots \ldots \ldots \ldots$ in envelope

\section{TABLES}

1. Late Pleistocene-Holocene climate and chronology of the ESRP and vicinity ....... 12

2. Summary of trench environment, location, and names $\ldots \ldots \ldots \ldots \ldots \ldots$

\section{PLATES}

1. Aerial photograph of Eight Mile Fan at a scale of $1: 40,000 \ldots \ldots \ldots \ldots \ldots \ldots$

2. Intermound soil on the left side of 8 MFM2 $\ldots \ldots \ldots \ldots \ldots \ldots \ldots \ldots \ldots$

3. Central disturbed section of 8 MFM2 $\ldots \ldots \ldots \ldots \ldots \ldots \ldots \ldots \ldots \ldots \ldots$

4. Soil crack in 8 MFM2 $\ldots \ldots \ldots \ldots \ldots \ldots \ldots \ldots \ldots \ldots \ldots \ldots \ldots \ldots \ldots \ldots$

5. Intermound soil position at left end of trench 8 MFM4 $\ldots \ldots \ldots \ldots \ldots \ldots \ldots$

6. Disturbed soil in the central section of 8 MFM4 $\ldots \ldots \ldots \ldots \ldots \ldots \ldots \ldots \ldots$ 
7. Soil on the right side of trench 8 MFM4, showing the basal gravels $\ldots \ldots \ldots \ldots \ldots 33$

8. Aerial photograph of the Big Lost River showing the $\mathrm{Qa}$ and $\mathrm{Qb}$ terraces and the

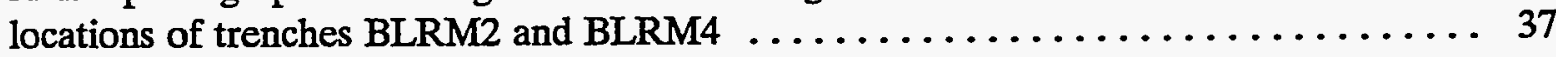

9. Photograph showing the difference in pavement between the mound and intermound

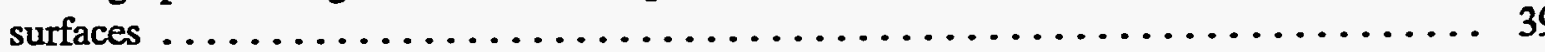

10. Intermound soils at the left side of BLRM $2 \ldots \ldots \ldots \ldots \ldots \ldots \ldots \ldots \ldots \ldots$

11. Disturbed soils in the central section of BLRM2. ................... 43

12. Intermound soil at right side of BLRM4 $\ldots \ldots \ldots \ldots \ldots \ldots \ldots \ldots \ldots \ldots \ldots$

13. Intermound soil at left side of BLRM4 $\ldots \ldots \ldots \ldots \ldots \ldots \ldots \ldots \ldots \ldots \ldots$

14. Central disturbed section in BLRM4 $\ldots \ldots \ldots \ldots \ldots \ldots \ldots \ldots \ldots \ldots \ldots \ldots \ldots$

15. Aerial photograph showing the location of RWMCM1 and IPM2 $\ldots \ldots \ldots \ldots \ldots 53$

16. Photo showing the buried rock lines and soils in RWMCM1 $\ldots \ldots \ldots \ldots \ldots \ldots$. 57

17. Soil profile near the left-center section of RWMCM1. ............... 57

18. Photograph of the disturbed soil near the center of RWMCM1 $\ldots \ldots \ldots \ldots \ldots \ldots 59$

19. Photograph showing the entire length of IPM2. $\ldots \ldots \ldots \ldots \ldots \ldots \ldots \ldots \ldots \ldots$

20. Intermound soil at right end of IPM2 $\ldots \ldots \ldots \ldots \ldots \ldots \ldots \ldots \ldots \ldots \ldots \ldots \ldots \ldots \ldots \ldots$

21. Central disturbed zone in IPM2 $\ldots \ldots \ldots \ldots \ldots \ldots \ldots \ldots \ldots \ldots \ldots \ldots \ldots \ldots \ldots \ldots \ldots \ldots \ldots$

22. Frost heaved basalts in the base of IPM2 $\ldots \ldots \ldots \ldots \ldots \ldots \ldots \ldots \ldots \ldots \ldots \ldots$

23. Air photo showing the location of RGFM1 $\ldots \ldots \ldots \ldots \ldots \ldots \ldots \ldots \ldots \ldots$

24. Photograph showing the surface of RGFM1 $\ldots \ldots \ldots \ldots \ldots \ldots \ldots \ldots \ldots \ldots \ldots$

25. Photograph showing the downslope intermound soil at the left of RGFM1 $\ldots \ldots \ldots 71$

26. Photograph showing the upslope intermound soil in RGFM1 $\ldots \ldots \ldots \ldots \ldots \ldots .73$

27. Photograph of a wedge in the intermound soil of RGFM1 remnant soils $\ldots \ldots \ldots \ldots 77$

28. Photograph showing soil fractures in the intermound soil of RGFM1. $\ldots \ldots \ldots \ldots .77$

29. Photograph showing the central disturbed zone in RGFM1 $\ldots \ldots \ldots \ldots \ldots \ldots \ldots$ 


\section{Characteristics and Origin of Earth-Mounds on the Eastern Snake River Plain, Idaho}

\section{INTRODUCTION}

This report was originally published in May 1995 as a Master of Science thesis from Idaho State University. The work was partially funded by the Department of Energy, and was published here to allow greater distribution of the results.

Earth mounds on the Eastern Snake River Plain (ESRP) are subtle landforms often overlooked by casual observation. They are generally round or oblong, with diameters ranging from 8-14 meters. Their highest point is typically less than a half-meter above the adjacent intermound area. Sloping sides and gradational margins make the mound/intermound boundaries difficult to pinpoint. However, vegetational differences between the mounds and intermounds are striking, simplifying their identification. Vegetational differences vary; e.g., areas dominated by sagebrush communities usually have more and taller sagebrush on the mound; and areas dominated by grass communities usually have increased abundance of annual species on the mound. Adjacent mounds are always separated by some distance, usually up to several times the diameter of the mounds. The observed distribution patterns vary from an apparent regular spacing, to random occurrences, to strongly linear alignment. They formed on a variety of sedimentary deposits including river terraces, alluvial fan surfaces, and loess deposits on basalt flows. The mounds occur on both flat and sloping surfaces. Essentially all mounds observed in this study are, or have been, occupied by burrowing mammals.

Similar earth mounds are found elsewhere in the world, but in the United States they generally occur west of the Mississippi River. Origins of the North American mounds puzzled early explorers and settlers, and have continued to puzzle scientists since the 19th century. North American mounds were labeled with many names including Mima mounds, mimalike mounds, patterned ground, pimple mounds, hogwallows, silt mounds, and pimple prairie. Some names are associated with specific locations, i.e., Mima mounds for mounds on the Mima Prairie in Thurston County, Washington; and patterned ground for soil features formed in periglacial environments, or areas of permafrost. Although the ESRP mounds share many characteristics of mounds in other areas, they are called "mounds" here for simplicity and not to imply any genetic connections.

The origin and age of mounds found in different geographic regions are puzzling because the environments they formed in exhibit such a wide range of variability. Their origins have been studied by researchers in the fields of geomorphology, geocryology, pedology, biology, and ecology (among others). It is possible that processes from any or all of those fields may relate to their formation. Although the morphology of mounds can be superficially similar from region to region, there is no universally accepted theory for their origin. 


\section{BACKGROUND}

\section{Objective}

The objective of this research was to determine the age and origin of earth mounds on a segment of the ESRP within the Idaho National Engineering Laboratory (INEL). The results have implications for predicting the long-term stability of the landscape.

The work was partly funded by the Department of Energy (DOE) Low-Level Radioactive Waste (LLW) Management Program. The DOE (and its predecessor Atomic Energy Commission) has operated the INEL since 1949 to conduct nuclear energy-related research. Disposal of LLW began in 1952, and DOE is responsible for the continued safe operation and closure of the LLW disposal facility. Long-term landscape stability (specifically erosion which may uncover buried waste) must be accounted for in the performance assessment of the disposal facility.

\section{Theories of Mound Origin}

Earth mounds have been studied in many geographic regions by scientists from a variety of specialties. Given the complexity of the problem, multiple mound development theories have been championed. Although some researchers feel that a single hypothesis must be applied to all mounded regions, others feel mound development may be polygenetic, and probably differs regionally. In fact, consensus has not been reached even in well-studied mound regions. Most theories of mound origin fall within one of five main categories: 1) frost action, 2) burrowing mammals, 3) depositional processes, 4) erosional processes, and 5) seismic shaking. Several detailed reviews focused on historical and recent arguments for and against different mound development hypotheses. The reviews were applied to specific mounded regions: Washburn (1988, Mima mounds of Thurston County, Washington), Tallyn (1980, Palouse country of eastern Washington), Spackman (1982, Laramie Basin, Wyoming), and Alldritt (1979, east-central Idaho). Spackman (1982) provided a table of mound origin hypotheses starting as early as 1845 . This table has been expanded with current literature and is attached as Appendix A (note: this appendix contains a separate reference list from that at the end of this document). The length of the table illustrates the wide interest mounded microtopography has generated both historically and today. The following discussion is brief; no attempt was made to describe the many nuances of these arguments, or to support or refute their applicability to the mounds on the ESRP.

\section{Mammal Activity}

The hypothesis of mound building by fossorial rodents was detailed by Dalquest and Scheffer (1942) and Scheffer, (1947), and supported by others, mainly biologists (Arkley and Brown, 1954; Cox, 1984a; Cox and Gakahu, 1984; Cox and Allen, 1987; Cox and Roig, 1986; Cox and Scheffer, 1991; Mielke, 1977; Wallace, 1991). The theory is that burrowing mammals tunnel outward from their nests, displacing the soil behind them. This soil is packed into abandoned chambers or pushed out to the surface, eventually building the mound over a period of extended use. In a region with uniform soil and substrate conditions, the territorial and foraging behavior of the mammal will result in a regular distribution of mounds (Dalquest and Scheffer, 1942; Huntley and Reichman, 1994). Mammals build nests in deep well-drained soil for protection from flooding, predation, or intense winter cold (Cox and Scheffer, 1991). By this process, mounded terrain is 
best formed in regions with shallow (less than twelve inches) silty soil overlying a basement layer such as bedrock, hardpan, densely bedded gravel, heavy clay, or a permanent water table.

Although the substrate causes the surface soil to become saturated during wet seasons of the year (Cox, 1984), the mounds provide protection for the mammals. Mounds are not formed by burrowing activities in areas of deep, well-drained soil (Washburn, 1988). Washburn (1988) provides a point-by-point discussion of the burrowing mammal hypothesis, offering alternative explanations for evidence attributed to mammals, and highlighting problems with the evidence as it applies to the Thurston County, Washington mounds.

\section{Erosional Hypotheses}

Proponents of the erosion hypothesis argue that the mounds are remnants of a more uniform thickness of soil which has subsequently been eroded off by wind, ice, or flowing water. Variants of this hypothesis include random slopewash runoff, runoff erosion with vegetation anchoring (Washburn, 1988), or preferred runoff/erosion patterns due to some type of jointing in the soil or substrate. Preferred runoff patterns may be caused by bedrock joints (Washburn, 1988), polygonal permafrost cracks (Pewe, 1948; Ritchie, 1953), desiccation cracks (Knechtel, 1952), or seasonal frost cracks, (Washburn, 1988). The higher density of coarse clasts on intermound surfaces in some regions is usually attributed to removal of fines leaving a lag of coarse rocks. The downslope alignment, and elliptical geometry of mounds formed on slopes is generally attributed to water runoff. This is the process accepted by Wilson (1977) for the Western Snake River Plain mounds near Boise, Idaho. The detailed review by Washburn (1988) includes a complete discussion of historical and present ideas concerning the role of erosion in forming mounds. He considered runoff erosion controlled by vegetation anchoring as a strong possibility for development of the Mima mounds in southwestern Washington.

\section{Depositional Hypotheses}

The depositional hypotheses for mound building invoke ice, water or wind as the primary agents for sediment transport, and vegetation or other frictional features as the primary stabilizers. Depositional theories are necessarily adapted to mound-specific regions due to the need to explain sediment source, ice and/or water source, age of transport, mechanism of deposition and stabilization, and so forth. Deposition by ice or fluvial activity is not widely accepted as a viable argument for the formation of mounds because the theories are too site-specific for general application. Deposition by wind is not widely accepted because the grain sizes found in many mounded regions are too large for wind transport (Washburn, 1988).

\section{Seismic Shaking}

The theory of mound building by seismic shaking is relatively new and has not received a great deal of attention. The seismic shaking theory (Berg, 1990, 1991) is that mounds are formed as a result of vibration of fine-grained, unconsolidated sediments on a relatively rigid planar substrate. The substrate may be comprised of bedded gravels, "stiff" sandy loam, clay layers, or any layer which comprises a reflective surface for transmitting seismic waves (Berg, 1991). Saucier (1991) objected to the application of the hypothesis to mounds in the lower Mississippi Valley on the basis that a suitable substrate did not exist and that seismically induced sand boils exist in areas not populated by mounds. 


\section{Frost Hypotheses}

The physical environment in a periglacial climate is a reflection of a multitude of complex, interrelated factors including soil characteristics, water content, air temperature, and vegetation cover. Many landforms result from freezing processes, including pingos, palsas, and earth hummocks, as well as various forms of patterned ground. Patterned ground was defined by Washburn (1956, p. 824) as "a group term for the more or less symmetrical forms, such as circles, polygons, nets, steps, and stripes, that are characteristic of, but not necessarily confined to, mantle subject to intensive frost action." Tallyn (1980) suggested that mounds fit into this classification as circular or net forms. Washburn (1956) developed a description and classification of patterned ground, and provided a review of possible explanations for the various features. His conclusion was that patterned ground is polygenetic, some forms are combination products of different processes, and their origin is uncertain.

Mounds have been attributed to several processes related to periglacial climates. Malde (1961, 1964) and Fosberg (1965) related the Western Snake River Plain mounds to solifluction of saturated sediment on a frozen substrate. Newcomb (1952) and Pewe (1948) related mounds in Washington to the formation of polygonal ice wedges. By this hypothesis, expansion of the ice wedges caused the sediment within the polygon to bulge upward. The mounds remained as remnants upon thawing of the wedge ice. Ritchie (1953) suggested erosion of the intermound areas by preferential channeling of meltwater through the polygons. Tallyn (1980) considered mounds on the Columbia Plateau in eastern Washington the product of frost sorting during a periglacial climate. Spackman (1982) attributed mounds in the Laramie Basin, Wyoming to cryostatic pressure created from water trapped between a layer of permafrost or bedrock and a downward freezing frost layer.

The role of frost action in creating the multitude of landforms observed in today's periglacial climates is complex. In general, ice begins to freeze at the land surface and progresses downward with freezing of the water held in soil pores. Given conditions necessary to develop adequate suction potential (i.e. fine grain size, adequate moisture content), pore water will migrate from deeper, unfrozen soil to the freezing front. Ice crystals will grow in a plane normal to the direction of freezing, thus forming an ice lens parallel to the ground surface. The growth of the initial ice lens stops when moisture supply is diminished or the "shut-off" pressure (the effective stress at which the flow of moisture to or from the freezing front is stopped) is reached (Washburn, 1980, James, 1971). A subsequent, deeper ice lens will form as the freezing front advances into the soil. The ice lenses are typically millimeters or less in thickness, are discontinuous, and occur in both horizontal as well as vertical planes. This process will continue as long as necessary hydraulic and thermal conditions prevail in the system.

The freezing process and formation of ice within the soil is a complex thermodynamic reaction which varies as functions of grain size and shape, moisture content, temperature, pressure, mineralogy, and the whether the system is closed or open to moisture input. Grain size affects both the freezing temperature of capillary water, and the movement of moisture to the freezing front (Washburn, 1980). Smaller grain sizes (i.e., silt and clay) cause freezing at a lower temperature due to increased area of contact between solids and water. Additionally, suction potential increases as grain size decreases. However, clay-size grains cause a decrease in permeability, thus inhibiting the growth of ice lenses. Silt-size grains are the most frostsusceptible (Washburn, 1980). 
Sufficient moisture content is critical for the formation of ice lenses, and strongly affects the physical results of the frost activity (Washburn, 1980). A closed system is one in which the volume of water available for freezing is fixed; thus, moisture does not flow into the system and the soil becomes desiccated. Heaving in a closed system is limited due to lack of water available for the continued growth of ice lenses. In an open system, water flows to the freezing front from deeper unfrozen soils and, depending on other factors, does not limit the potential for heaving.

The temperature in the system affects the rate of freezing of soil water which in turn affects the thickness of ice lenses. Rapid freezing inhibits the growth of ice lenses. Temperature of freezing is strongly dependent on grain size, pressure, and chemistry within the system. Mineralogy within the system can affect both the availability of moisture and the temperature of freezing. Clay minerals affect the mobility of water depending on the amount they hold in their

crystal lattices. Expandable clays inhibit the growth of ice lenses, while non-expandable clays are frost-susceptible (James, 1971; Washburn, 1980). The presence of salts in the soil can lower the freezing point of water, thus inhibiting growth of ice lenses. Salt additives have been experimented with to decrease frost heaving of engineered structures.

The physical effects caused by the action of freezing processes vary widely. Freezing processes account for the upward migration of stones, sorting of grain sizes, differential volume expansion of soils, prying apart or shattering of rocks, and development of multitudes of patterned ground formations. The exact processes accountable for all the observed features have been the subject of numerous studies, and are not yet fully understood.

\section{Previous Investigations}

Patterned ground was recognized on the Western Snake River Plain near Bliss and Twin Falls, Idaho by Malde $(1961,1964)$ and Fosberg (1965). Both attributed formation of the features to solifluction of soil on a frozen substrate, and assigned their age and origin to a periglacial climate associated with the last glacial episode (Pleistocene). Wilson (1977) noted the resemblance of these mounds to patterned ground of periglacial origin, but concluded the features resulted from erosion of intermound soils by alluvial processes. Nace et al. (1956) observed earth mounds on the ESRP, specifically on terraces of the Big Lost River where it crosses the INEL. He mapped mounds only on the older fluvial terraces, and suggested they were formed during a period of periglacial or related climate at the close of the Pleistocene. Alldritt (1979) studied patterned ground in the Birch Creek Valley, Idaho, north of the ESRP. His work focused on a test of the erosional hypothesis of mound formation, and concluded that erosion was not the causal agent. He suggested that processes related to aspects of biota, vegetation, microclimate, and soil texture and development may all be implicated in mound development.

\section{Regional Setting}

An understanding of the geology, soils, climate, vegetation, and biota of the ESRP is necessary to evaluate the data obtained in this study with respect to the timing and processes potentially involved in mound formation. The following information provides a basic background of the setting in which the mounds formed. 
The Snake River Plain cuts a broad, arcuate swath across southern Idaho. The ESRP is that segment which extends from south-central Idaho (near Twin Falls) northeastward to the Yellowstone Plateau. The INEL occupies the northwest segment of the ESRP (Figure 1). Elevations on the ESRP rise from $1000 \mathrm{~m}$ in the west to 2,000 m in the northeast. Except for several prominent buttes (Big Southern Butte, East Butte, and Middle Butte) the topography is subdued. Basin and Range fault block mountains border the ESRP on the north and south and provide relief of 1000 to 2,000 meters (Figure 1). The Yellowstone Plateau is a high elevation, volcanic terrane deeply dissected by rivers and glacial activity.

The ESRP is a volcanic province comprised of silicic volcanic rocks overlain by numerous basalt lava flows. All but the youngest basalts are overlain by eolian, alluvial, and lacustrine sediments which have generally smoothed the ruggedness of the surface landscape (Figure 2). The Big Lost River, Little Lost River, and Birch Creek drain the northern mountain ranges and flow south onto the INEL. The rivers terminate in closed basins and recharge the Snake River Plain Aquifer. Surface water runoff originating on the INEL consists of sheet wash, gully wash, and intermittent flow in incipient drainages. Drainages are controlled by lava flow margins and typically end in small playa basins. No surface water on the INEL reaches the Snake River which is the only drainage exiting the ESRP.

Late Quaternary glacial/interglacial climates had a large influence on the deposition and erosion of terrestrial sediments, pedogenesis, and development of the present geomorphic landscape. Multiple Pleistocene glaciations occurred on the Yellowstone Plateau and in the mountain ranges north of the ESRP (Richmond, 1965, 1986; Knoll, 1977; Butler et al., 1982; Dort, 1962; Evenson et al., 1982).

During periods of regional glaciation, loess accumulated on basalt flows in deposits up to several meters thick. Sources of the loess apparently included the aggrading river valleys, active alluvial fan surfaces, and fluctuating pluvial lake margins located adjacent to the ESRP (Scott, 1982; Pierce and Scott, 1982; Forman et al., 1993). The loess stratigraphy includes at least two distinct loess units separated by a well developed paleosol (Forman et al., 1993; Pierce et al., 1982). Thermoluminescence age dating indicates that periods of loess deposition are correlative to periods of regional glaciation. The youngest loess, Loess A, was deposited 40,000 to 10,000 years ago. The older loess, Loess B, was deposited 80,000 to 60,000 years ago. Periods of loess deposition were separated by a period of milder climate during which a well-developed soil was formed (Forman et al., 1993).

The soils developed on mounded surfaces are important in establishing the chronology of mound formation. Pedogenesis in the loess occurred between glacial episodes, or individual advances (if they were long enough). The degree of weathering results from and indicates either the length of time prior to burial by additional sediment, or the intensity of the weathering processes. Paleosols in loess deposits on the ESRP have been recognized and described by McDole (1969), McDole et al. (1973), Pierce et al., (1982), Lewis and Fosberg (1982), Lewis (1986), (Forman et al., 1993; and Dechert et al. (1994). Generally paleosols are recognizable by a higher degree of soil development relative to the surficial soils. They have a thicker calcic horizon with higher calcium carbonate equivalent, higher clay contents, stronger chroma, and thicker B horizons (Lewis, 1986). Paleosols typically lack the A horizon, and leaching of calcium carbonate from overlying sediments may mask the buried soil horizons. 


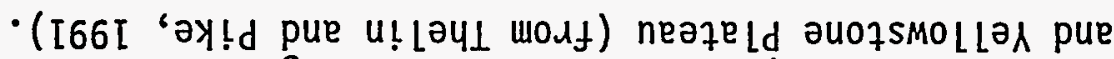
su!equnow әБuey pue u!

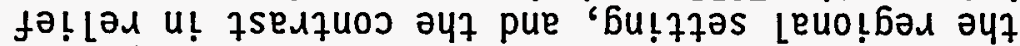

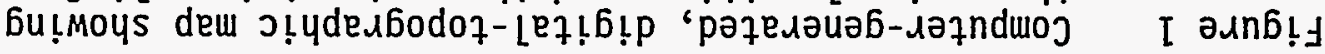

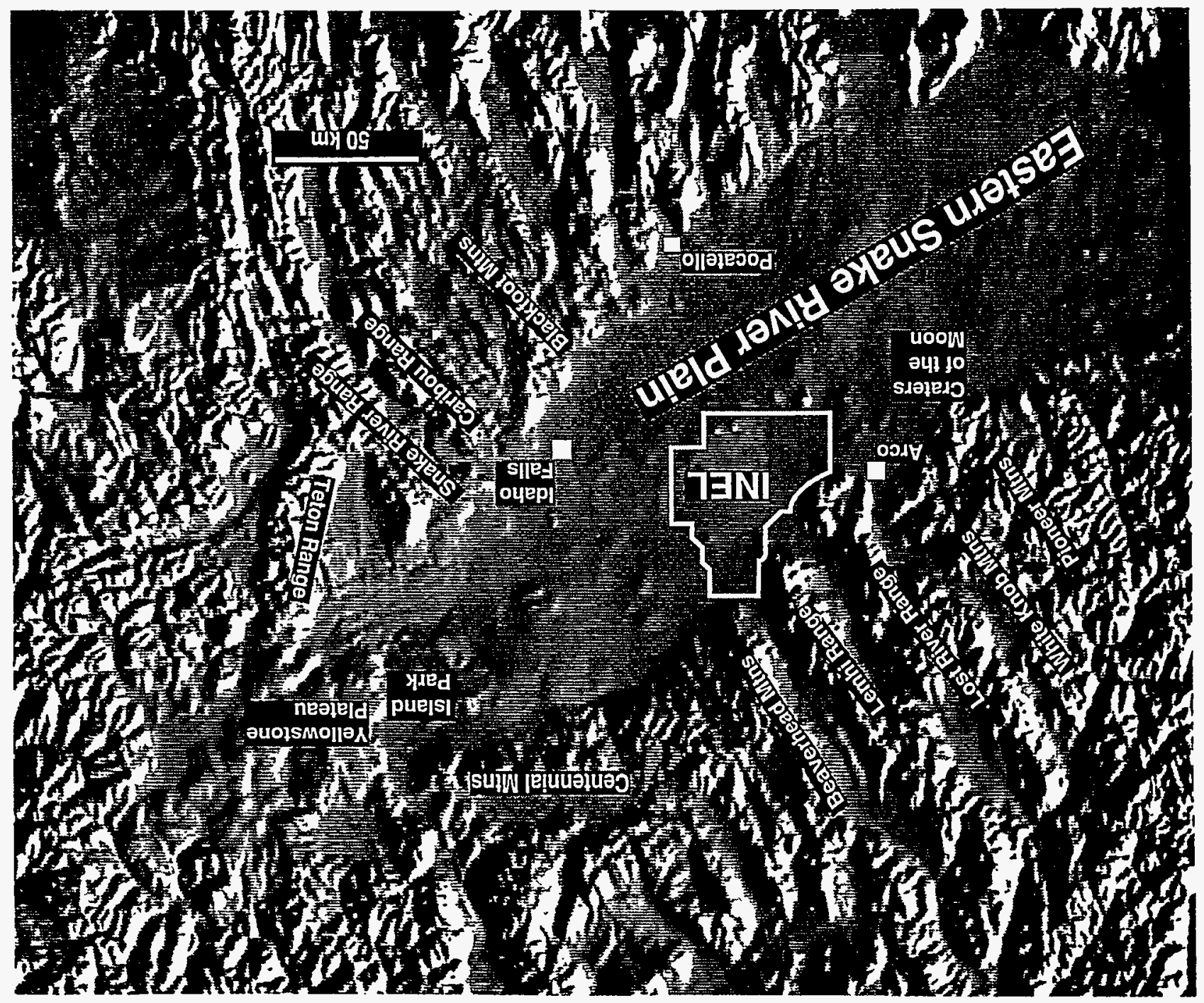




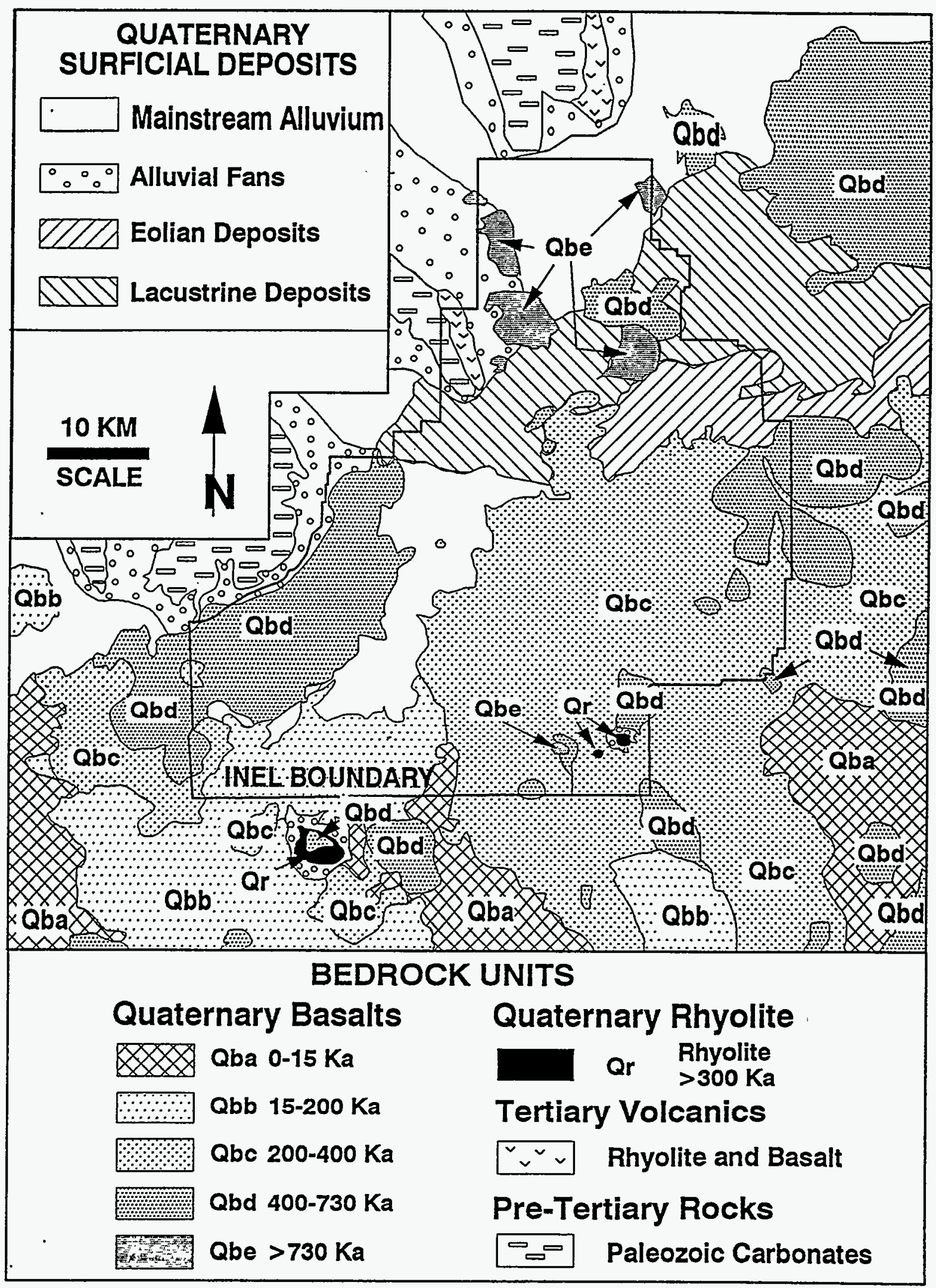

Figure 2 Generalized geologic map of the INEL area showing the distribution of basalt flows and thick sedimentary deposits. (adapted from Kuntz and others, 1990 and Scott, 1982) 
Multiple buried soils have been identified in thick loess units of the ESRP. Although the number of paleosols generally indicate increasing age (Lewis, 1986), absolute age dates are not available. The prominent paleosol which separates Loess A and B is thought to have developed over several tens of thousands of years (Pierce et al., 1982). Multiple paleosols within loess units indicate that loess was deposited in a series of pulses during each period of regional glaciation (Forman et al., 1993).

The Holocene soil developed in Loess $\mathrm{A}$ generally exhibits an $\mathrm{A}, \mathrm{Bw}, \mathrm{Bk}, \mathrm{C}$ horizon sequence (Dechert et al., 1994). Textures are mainly silt loams, with slightly sticky, slightly plastic moist consistence, moderately to strongly calcareous, and platy or subangular blocky structures. This level of soil development is thought to have developed since the end of Pinedale time, 10-15 ka (Pierce et al., 1982; Lewis and Fosberg, 1982).

Holocene erosion of the loess on the INEL is largely confined to redistribution of the upper decimeter of surface sediments on the uneven topography of the lava flows (Hackett et al., 1995). Hillslope processes of creep and slopewash have resulted in movement of fine-grained particles downslope and redeposition in playas on the basalts. Entrainment and removal of sediments by eolian processes has resulted in the redistribution and perhaps removal of the upper sediments in areas where stabilizing vegetation has been disturbed by wildfires or anthropogenic activity. An analysis of Late Pleistocene-Holocene erosion at a small basin within the INEL indicated up to $50 \mathrm{~cm}$ of surficial sediments have been removed from slopes now occupied by mounds (Dechert et al., 1994). However, the presence of correlative loess units and the distinctive paleosol separating them, indicates the lack of general, widespread erosion on the scale of meters.

As with the timing of loess deposition, the deposition of alluvial gravels on the ESRP was concentrated during periods of regional glaciation (Scott, 1982). On the INEL, alluvial deposition occurred on the floodplain of the Big Lost River (Figure 2) during periods of increased discharge of glacial meltwater and during at least one catastrophic glacial-outburst flood. (Alluvial deposits from the Little Lost River and Birch Creek are mapped at the north end of the INEL, but were not investigated for mounds.) Decreases in river discharge during interglacial periods resulted in incision of fills and erosion of terraces (Scott, 1982).

Catastrophic outburst flooding removed a significant portion of surficial sediment from alluvial terraces now occupied by mounds. The age of the flooding therefore provides a maximum age for development of the mounds. Glacial-outburst floods originated from Glacial Lake East Fork which was formed by the impoundment of meltwater from the Copper Basin glaciers by an ice lobe extending from Wildhorse Creek into the East Fork of the Big Lost River drainage. Multiple glacial-outburst floods resulted from minor fluctuations of the ice margin position (Evenson et al., 1982). Floodwaters flowed north and east to the area of Chilly Buttes and turned south along the present channel of the Big Lost River. The floods entered the ESRP at Arco and entered the INEL at its western boundary. The flood waters were not confined to the river channel once they reached the ESRP. At and downstream of Box Canyon (between Arco and the INEL), the floodwaters eroded multiple cataracts in basalt outcrops, streamlined basalt ridges, removed the loess cover and scoured a broad plain of bedrock, and transported huge basalt boulders which were then deposited in large trains. Rathburn $(1989,1991,1993)$ mapped these erosional and depositional features of the flooding and used step-backwater techniques to model 
peak discharge ( 2 - 4 million cfs). Dating of the flood event using cosmogenic ${ }^{3} \mathrm{He}$ and ${ }^{21} \mathrm{Ne}$ indicates a late Pinedale age of 16,900 years BP (Cerling et al., 1994).

Climate is an important element in evaluating hypotheses for mound development. Details on Quaternary climates for the ESRP are sketchy; however, proxy data (e.g., pollen, lake-level data, packrat middens) have been used to infer climate patterns. During full glacial conditions of $18 \mathrm{ka}$, pollen records from Grays Lake indicate a cold and dry climate (Beiswenger, J.M., 1991). Although precipitation in the western USA was low at this time, the effective moisture was higher than at present due to reduced evaporation. Summer temperatures may have been depressed by as much as $10^{\circ} \mathrm{C}$ (Thompson et al., 1993).

By $13 \mathrm{ka}$, the transition from full- to late-glacial conditions had begun adjacent to the ESRP. Alpine glaciers and the Cordilleran ice sheet had retreated from their full glacial maxima. Temperatures were warmer than before, but cooler by $3-4.5^{\circ} \mathrm{C}$ than today, and winter precipitation had increased (Thompson et al., 1993).

Starting at $10 \mathrm{ka}$, the climate on the ESRP became relatively warmer and drier, culminating in the xeric maximum (Altithermal) around $7 \mathrm{ka}$ (Table 1) (Hackett et al., 1995). The last shift occurred around $5 \mathrm{ka}$ (depending on the location, as shown on Table 1), when the climate shifted back to a cooler and wetter period called the Neoglacial. This change was accompanied by advances of alpine glaciers, and increased alpine periglacial activity.

The present climate of the ESRP reflects its elevation, latitude, and intermountain geographic setting (Clawson et al., 1989). Mountain ranges bordering the ESRP channel the prevailing westerly winds so they usually come from the southwest with secondary flow from the northeast. Air masses moving inland from the coast lose moisture on the west side of mountain barriers so that air masses moving onto the ESRP are generally drier. The region is classified as arid to semi-arid (Clawson et al., 1989). Intense daytime solar heating and rapid nighttime cooling result in a large diurnal range of temperature near the ground. At the INEL, the annual average temperature over a 38 -year period of record is $5.6^{\circ} \mathrm{C}$. Average annual precipitation is $22 \mathrm{~cm}$. The average depth of freezing temperatures in a bare sandy soil at the INEL was measured at $1 \mathrm{~m}$ (Clawson et al., 1989).

Vegetation on the ESRP is classified as sagebrush steppe with plant communities typical of the Wyoming sagebrush and bluebunch wheatgrass (Moody and Dort, Jr., 1990). Common shrubs in the mounded areas studied include sagebrush, rabbitbrush, and winterfat. Common grasses include bottlebrush squirreltail, needle-and-thread grass, Great Basin wildrye, and bluebunch wheatgrass. Common forbs include milkvetch, phlox, hawksbeard, yellow salsify, mustard, and halogeton.

Fourteen species of rodents are found on the INEL, most of which are burrowers. The most common burrowing mammals include the deer mouse, montane vole, Townsend's ground squirrel, Ord's kangaroo rat, least chipmunk, Great Basin pocket mouse, and western harvest mouse. 
Table 1 Late Pleistocene-Holocene climate and chronology of the ESRP and vicinity. These studies are based primarily on analysis of pollen from lake, bog, and cave deposits, supplemented by ecologic information from plant macrofossils, tree rings, vertebrate and invertebrate fossils, charcoal from wildfires, and characteristics of sediments. Chronologies were established by radiocarbon dating and tuffs. Environmental conditions are relative from past to present (from Hackett et al.. 1995).

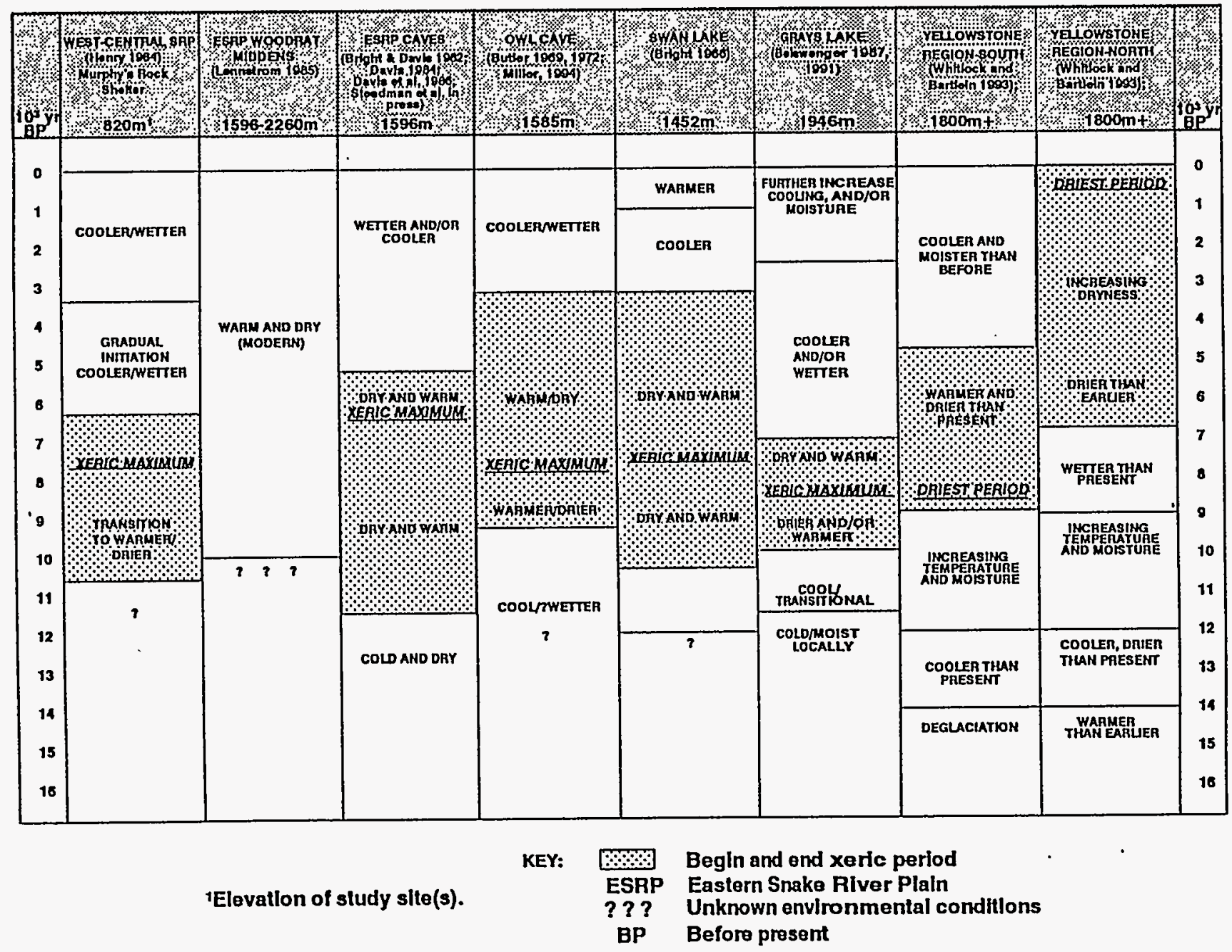




\section{STUDY APPROACH}

This study was designed to take advantage of the presence of mounds developed on a variety of sedimentary deposits within a single geographic region (ESRP). This setting limited the scale of differences in vegetation, mammal activity, and soil formation so that the variability associated with comparing mounds formed in different regions is reduced. Two main assumptions were used in designing the study: 1) mounds were initially formed by the same process, and 2) the effects of regional climate (i.e., glacial/interglacial temperature and precipitation regimes) and regional geologic events (i.e., seismicity, volcanism, glaciers) were essentially uniform at all mound sites.

A detailed description of all field and laboratory methods is provided in the following sections. In brief, several neighboring mounds in seven separate locations on the NEL were trenched using a backhoe. The trenches extended across the entire mound and into the intermound on either end. All mounds were visually inspected, and seven were selected for detailed logging. Trench selection was based on working convenience, best exposure for lighting, and least backhoe disturbance, rather than on the mound characteristics. Table 2 provides a summary of the sedimentary deposit, the location, and the name for each trench logged in this study.

A detailed log was made for each trench to characterize the stratigraphy, soils, structures (e.g., wedges, cracks, etc.), and mammal activity. Samples were collected for laboratory analyses to assist in identifying soil horizons, paleosols, and stratigraphic units. Determination of mound origin was based on identification and interpretation of features unique to individual mounds, and features common to all mounds. Determination of mound age was based on the age of the youngest sedimentary deposit on which mounds formed (maximum mound age) and the relationship of mound formation to pedogenesis (minimum mound age).

Table 2 Summary of trench environment, location, and names.

\begin{tabular}{llc}
\hline \multicolumn{1}{c}{ Environment } & \multicolumn{1}{c}{ Location } & Trench name \\
\hline Loess/slopewash over basalt & Ryegrass Flats & RGFM1 \\
Loess over basalt & Infiltration Pond & IPM1 \\
Loess over basalt & Radioactive Waste & RWMCM1 \\
Bull Lake-age alluvial fan & Management Complex & \\
Pinedale-age alluvial fan & Eight-mile Fan & 8MFM2 \\
Late Pleistocene fluvial terrace & Eight-mile Fan & 8MFM4 \\
Late Pleistocene - Holocene age fluvial terrace & Big Lost River & BLRM2 \\
\hline
\end{tabular}




\section{Field Methods}

Mound diameter was measured using a fiberglass tape stretched across the untrenched surface, or along the trench wall. Either way, the measurements are typically accurate only to within a half meter because the mound edges are diffuse and difficult to pinpoint. Mound heights were estimated at the highest part relative to the nearest intermound surface. Cross sectional shape of the mound complicates determination of the height because mounds on slopes tend to have surfaces coplanar with the intermound area on the up-slope side, but steeper on the downslope side. Mound height and cross sectional shape are best exhibited on the trench logs.

Each mound was trenched using a tractor-mounted backhoe. Safety standards established by OSHA and DOE limited the maximum depth to $3 \mathrm{ft}$. 11 inches. The study face remained vertical, while the opposite wall and both ends were laid back at $45^{\circ}$ for egress. Basalt-floored trenches were cleaned with a broom. Sediment-floored trenches were cleaned of sloughed soils, and shovel pits were dug where necessary to characterize the deeper stratigraphy.

A horizontal reference line was established with string and nails on the vertical wall in each trench. Soil profiles were described at intervals sufficient for stratigraphic and pedogenic characterization. The profile positions were measured from the left end of the horizontal control (set at $0 \mathrm{~cm}$.) and the top and bottom of the profile were measured in reference to the horizontal string. Detailed descriptions were made of each profile using the method outlined in Birkeland. (1984) and the Soil Conservation Service Staff (1974). Abbreviated descriptions were made for profiles that did not show significant changes from the previous location. Horizon descriptions generally included thickness, texture, percent gravel, structure, dry and wet consistence, wet color (Munsell color chart), pores, roots, lime, and boundary. All soil profile descriptions are included in Appendix B. Typical profiles were sampled for laboratory analyses. Samples were taken using a trowel, and each was stored in a separate Ziplock bag. Samples were then stored in a dry, cool environment.

Each trench was photographed at $\approx 2 \mathrm{~m}$ intervals using a $35 \mathrm{~mm}$ camera, 100 ISO print film, and a $28 \mathrm{~mm}$ lens. Film was processed at the EG\&G Idaho, Inc. Photographic Laboratory as a contact sheet for archive storage (required by DOE regulations). Requested frames were then printed as color $8 \times 10$ s. A continuous montage of each trench was made by taping together the $8 \times 10$ prints. Overlays were drawn on frosted mylar. Slight scale changes and camera angle distortion make measurements from these logs inaccurate.

\section{Laboratory Analyses}

Physical and chemical characteristics were determined for some mound samples to assist in analysis of stratigraphic and pedogenic relationships. Samples that were representative of the intermound and mound soil profiles in each trench were analyzed for $\mathrm{pH}$ and electrical conductivity to assist in identifying soil horizons. A limited number of samples were analyzed for grain size and calcium carbonate content. Laboratory data were used only for qualitative confirmation of field interpretations, and not for quantitative analysis. Laboratory analyses were conducted at the Idaho Research Center, Geoscience Laboratory during the winter of 1994. Unless specifically referenced in the following descriptions, all analytical procedures were taken 
from the Soil Characterization Laboratory Procedures Manual (Falen and Fosberg, 1989). Results for the samples analyzed are reported in Appendix B. Methods for determining each parameter are given below.

\section{Sample Preparation}

All samples were air dried overnight in brown paper bags in the drying oven at $40^{\circ} \mathrm{C}$, then mixed and disaggregated using a large mortar and pestle. Care was taken to prevent crushing individual grains. The disaggregated soil was passed through a $2 \mathrm{~mm}$ sieve using hand shaking to remove gravels. Soil and gravels were weighed separately and the gravels were discarded.

\section{Saturated Paste}

A saturated paste was prepared by placing 500-1000 grams of prepared soil into a beaker, adding a known amount of distilled water, and stirring with a spatula. After allowing four hours to equilibrate, the sample was tested for proper saturation, and adjusted if necessary. At saturation, the sample glistens with reflected light, flows slightly when the beaker is tipped, and slides off the spatula. There should be no standing water on the sample surface, but the sample should not stiffen or become dull after standing. A known amount of water or soil was added to adjust the sample for proper saturation, and the sample allowed to reequilibrate for four hours. The weight of soil, and volume of water added was recorded, and percent water at saturation calculated according to the following formula:

Soil:water ratio $=\mathrm{g} \mathrm{soil} / \mathrm{mls}$ water

$\%$ water at saturation $=(\mathrm{mls}$ water/g soil $) \times 100$

pH

$\mathrm{pH}$ was determined using a Corning $350 \mathrm{pH}$ meter and a glass combination electrode. The electrode was inserted into the saturated paste and the $\mathrm{pH}$ read to the nearest tenth.

\section{Electrical Conductivity}

After $\mathrm{pH}$ measurement the liquid was extracted from the saturated paste using a filter candle apparatus as shown in Black (1965). Electrical conductivity (EC) on the first batch of samples were measured in millivolts using a Corning 350 combination meter. Erratic readings prompted a change to a Fisher Scientific Accumet meter which measured electrical conductivity in microseimens/cm. (Results reported in millivolts in Appendix B were obtained by the Corning meter and are suspect.)

\section{Calcium Carbonate Equivalent}

Calcium carbonate equivalent was determined using the approximate gravimetric method of Goh et al. (1993). A 1-10 gm sample of soil was added to a weighed, $50 \mathrm{ml}$ Erlenmeyer flask containing $10 \mathrm{ml}$ of a $\mathrm{HCl}-\mathrm{FeCl}_{2}$ reagent. $\mathrm{FeCl}_{2}$ is an antioxidant which eliminates errors caused by oxidizing interferences due to $\mathrm{MnO}_{2}$ in the soil. (Manganese nodules have been observed in some loess deposits on the INEL.) Carbonate was allowed to decompose at room temperature 
over a period of several hours, while monitoring the weight to the nearest $\mathrm{mg}$ at $\approx 30$-minute intervals. The reaction was considered complete after the weight of the flask with contents changed by no more than $2-3 \mathrm{mg}$. The calcium carbonate content was determined using the following calculation:

Weight of $\mathrm{CO}_{2}$ lost from carbonates = difference in initial and final weights of flask, stopper, and contents

$$
\% \mathrm{CaCO}_{3} \text { equivalent }=\left(\mathrm{g} \mathrm{CO}_{2} \text { lost/g soil }\right) \times 227.3 .
$$

Upon completion of the reaction, each sample was washed and filtered through the filter candle apparatus until $\mathrm{pH}$ paper indicated excess acid was removed. This method yielded approximate calcium carbonate equivalent only. For some samples with high soil carbonate content, the reaction went to completion with insufficient reagent to completely remove the carbonate. This was not discovered until the oven dried samples were dispersed for grain size analyses. In these cases, particles of calcium carbonate were observed under the microscope. The samples were reacidified for complete dispersion, but no effort was made to quantify the amount of calcium carbonate remaining in the sample. This was typical for Bk horizon samples from the trench at Ryegrass Flats (RGFM1). Therefore, calcium carbonate equivalent results should be taken as minimums.

\section{Pipette Analysis}

Particle size analyses for silt and clay were conducted by pipette. Oven dried samples were deflocculated using $10 \mathrm{ml}$ of a $5 \%$ sodium hexametaphosphate solution and an ultrasonic probe, then washed through a 230-mesh sieve into a 1000-ml graduated cylinder. Sediment left on the sieve was dried and weighed as the sand fraction. The cylinder was filled to the $1000-\mathrm{ml}$ mark with distilled water and placed into a constant temperature chamber. One minute after homogenization with a plunger/stirrer, a 25-ml sample was pipetted from the 10-cm mark and expelled into a labeled 50-ml sample beaker. Subsequent settling/sampling times and depths were determined using a table provided by the Soil Survey Laboratory Staff (1992). All samples were dried, cooled to room temperature, and weighed. Calculations were determined as follows:

Aliquot sample weight $=($ dry weight of sediment in aliquot - wt. of dispersant in aliquot) $\times 40$

Fraction weight is determined by successively subtracting individual dry sediment weight in each fraction from the next coarser.

After grain size analysis, soil textures were determined using the SCS triangle in Figure 3, and the name for that combination of clay, silt, and sand is reported in Appendix B. 


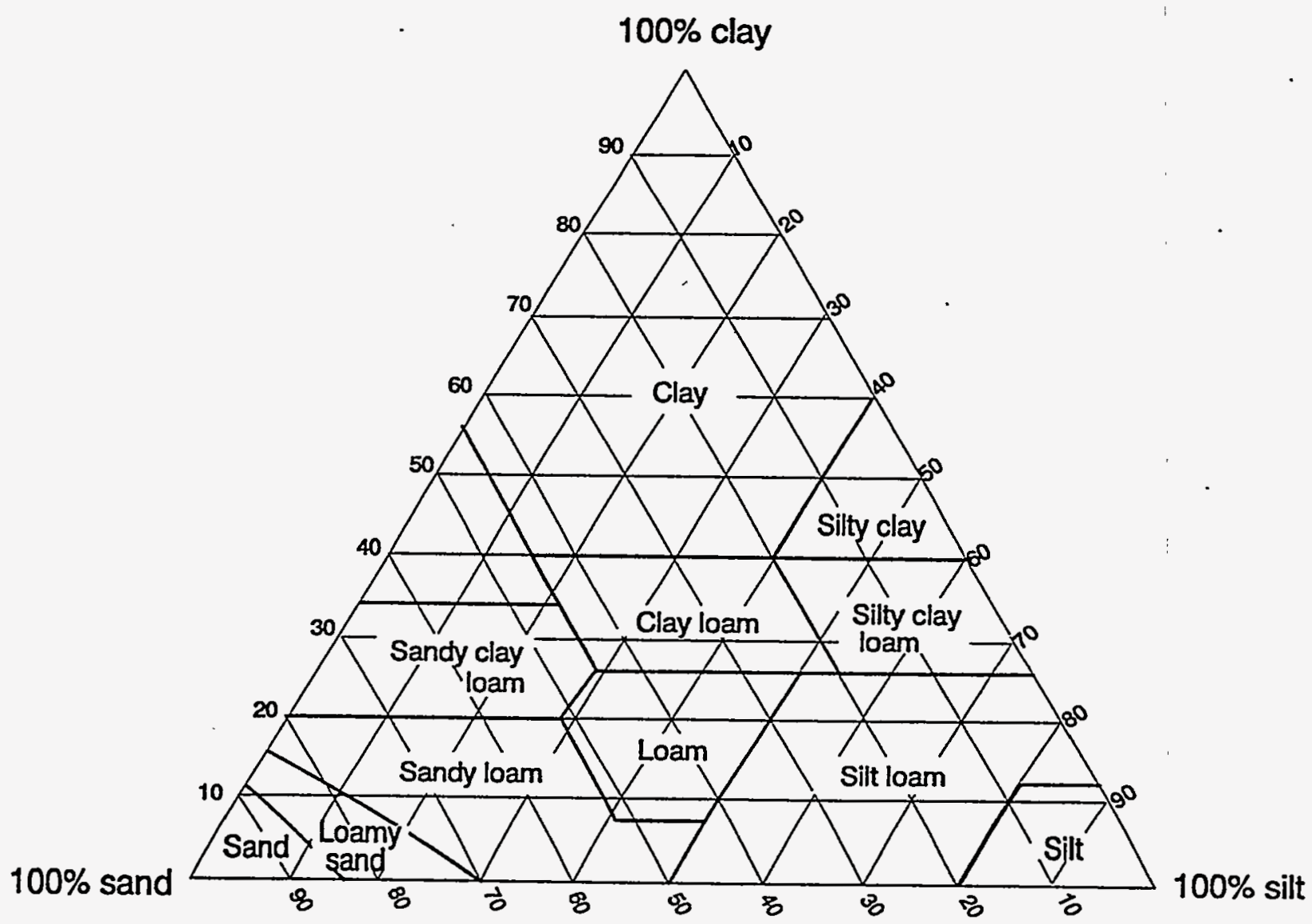

Figure 3 Soil textural classes plotted on a triangular diagram. (after Birkland, 1984) 


\section{SITE AND TRENCH DESCRIPTIONS}

Descriptions of the mounds become cumbersome with too much detail. To simplify the descriptions, most of the detailed field and laboratory data are included in two appendices. Appendix B contains soil profile descriptions recorded during field investigations and the laboratory data for soil samples. Appendix $\mathrm{C}$ contains details about the location and surface features of the study sites. The trench descriptions in this section highlight the stratigraphy, soils, structural features, and mammal activity used to interpret mound formation. Each trench description is accompanied by a cross-sectional log produced from field logs drawn over the photo-montages. These figures should be referenced for enhanced visual understanding of the trench descriptions.

\section{Alluvial Fan Mounds}

\section{Introduction}

Mounded microtopography is a prominent feature on alluvial fans developed at the base of the Lost River Range between Howe, Idaho and the intersection of US Highways $20^{\circ}$ and 26. Mounds occur on two distinct stratigraphic deposits mapped as af2 (younger) and af3 (older) by Scott (1982). These fan sediments were deposited during periods of high water discharge from mountain glaciers or thick snowpacks. The fans today are largely relict, with discharge occurring only during periods of intense rainfall or rapid snowmelt. Fan building has not occurred in the last 10,000 years (Scott, 1982),

Mounds on Eight-Mile Fan (eight miles west of Howe, Idaho) occur on both the af 2 and af 3 surfaces (Figure 4 and Plate 1). The af2 surface occupies lower topographic positions on both flanks of the fan. Af3 occupies the topographically higher, central segment of the fan extending from the apex to the toe. Both af 2 and af3 generally comprise pebble to cobble gravel, locally bouldery near fan heads, clast supported with sand and silty sand as matrix and distally as small lenses. Gravels are subangular to round, and exhibit medium to thick parallel beds and large-scale cross bedding (Scott, 1982).

Af2 is Upper Pleistocene (Pinedale) age (Scott, 1982) and is blanketed by a thin deposit of silty sediment with minor gravel in which a weak soil has developed. The soil is characterized by a cambic $\mathrm{B}$ horizon (20-50 cm thick) overlying a Bk horizon developed in bedded gravels (30$80 \mathrm{~cm}$ thick). Calcium carbonate on the bottoms of gravel in the Bk ranges from discontinuous coats to $1 \mathrm{~mm}$ thick continuous coats (Scott, 1982). Mounds on this surface have consistent morphology: circular in plan view, $<0.5$ meter in height, and $10-12 \mathrm{~m}$ in diameter. Mound edges are diffuse, grading into the surrounding intermound area. The mounds are recognized mainly by the increased height of sagebrush on the mound relative to the intermound.

Af3 is Middle to lower? Pleistocene age (Scott, 1982) [greater than 100,000 years old in most locations (Kuntz et al., 1990)], lithologically similar to af2, but with a greater thickness of silty sediments overlying the gravels. These sediments were deposited in multiple episodes and have stronger soil development with 2-10 mm thick calcium carbonate coats on clasts and a strongly cemented Bk horizon (Scott, 1982). Mounds developed on af 3 surfaces are strongly 


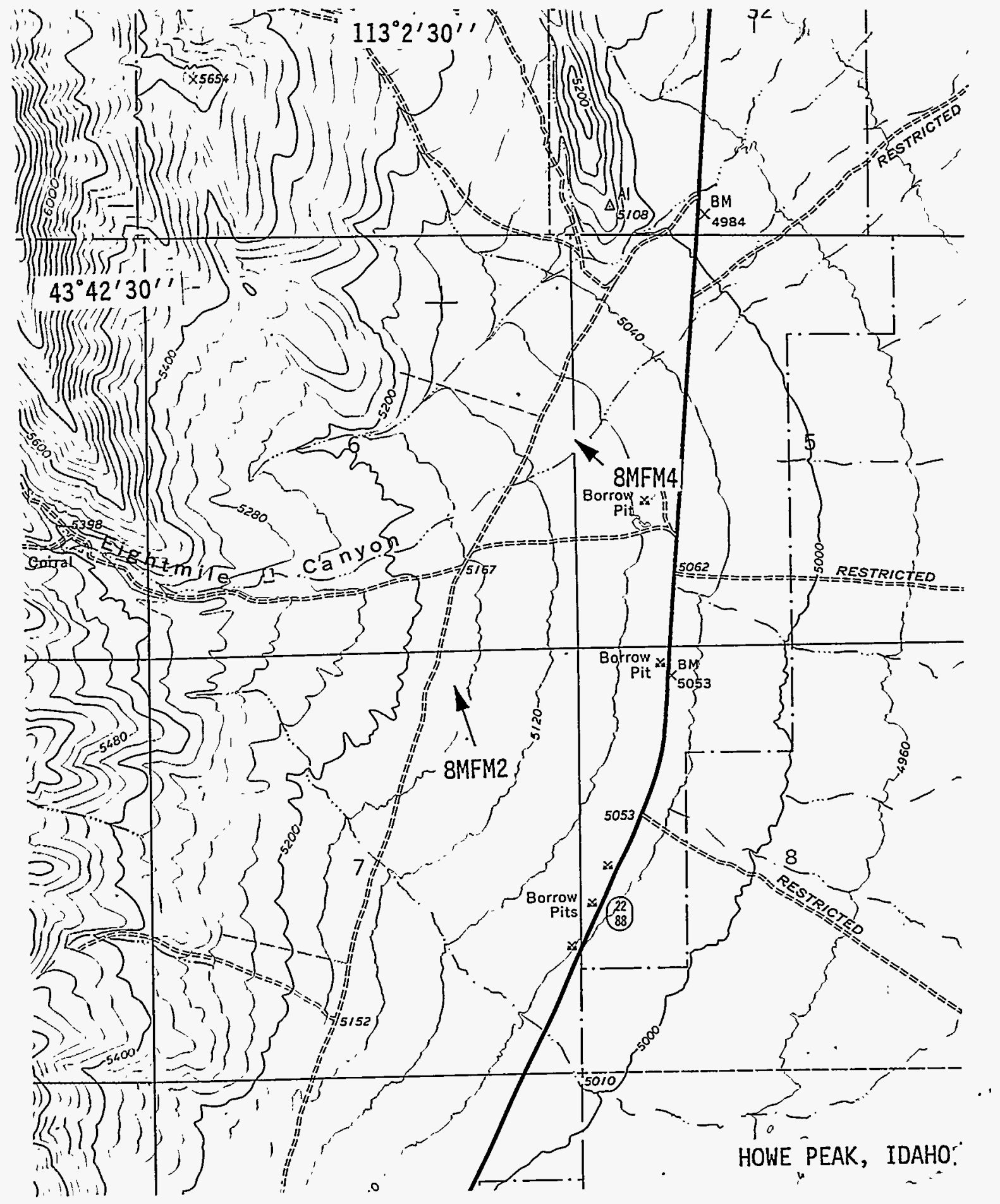

Figure 4 USGS 7.5 minute topographic map showing the location of 8MFM2 and 8MFM4 in relation to the Eight Mile Fan. 


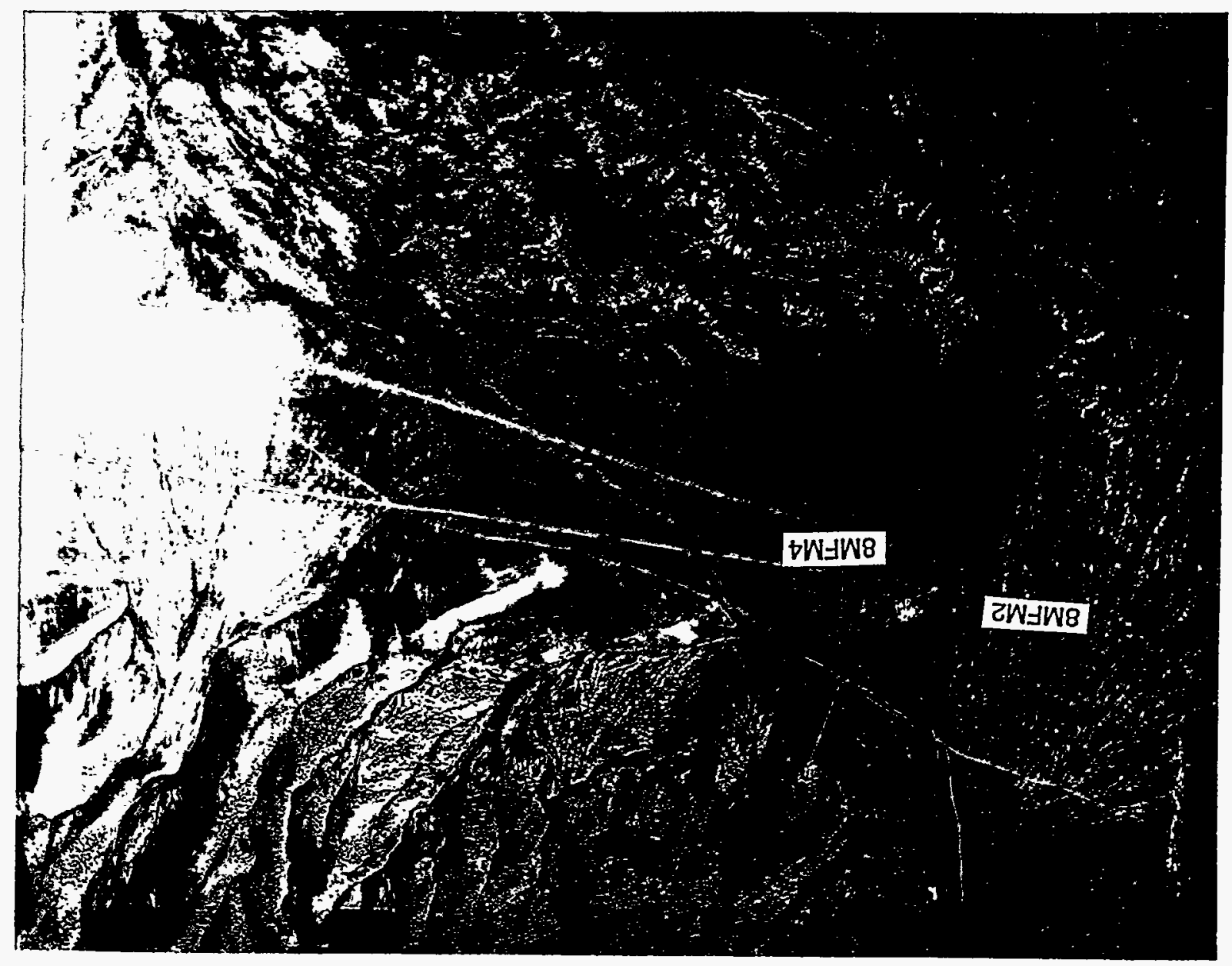




- .

1.

. 
aligned parallel to slope, occupying high areas between incipient drainage channels (Plate 1). The mounds tend toward a downslope oval shape in plan view, are up to $1 \mathrm{~m}$ in height, and $\approx 12 \mathrm{~m}$ in diameter. Mound edges are diffuse on the upslope side, but may be slightly more pronounced on the downslope edge.

\section{MFM2}

8MFM2 is located on the af3 deposit on Eight-mile fan (Figure 4 and Plate 1). It is part of a linear group aligned parallel to slope. The mound edges are indistinct, especially on the . upslope side where it grades imperceptibly into the intermound. The mound vegetation is dominated by sagebrush and winterfat. The intermound vegetation includes sagebrush, winterfat, prickly pear cactus, and other native plants. Mound/intermound vegetation is similar in spacing, however the amount of sagebrush and winterfat versus other plant species is increased on the mound, and the sagebrush is taller on the mound. Figure 5 (foldout in envelope) is a log of the $8 \mathrm{MFM} 2$ trench wall. The trench was oriented downslope with the left end of the trench on the upslope side $(0 \mathrm{~cm}$ trench position), and the vertical wall facing south.

The intermound soil on the left (upslope) side of the trench ( $40 \mathrm{~cm}$ profile) consists of an $\mathrm{A}, \mathrm{Bk} 1, \mathrm{Bk} 2,2 \mathrm{BC}, 3 \mathrm{BCb}$, and $4 \mathrm{BCb}$ profile (Plate 2). The parent material is gravelly silt, probably reworked loess, which overlies bedded alluvial fanglomerate. The gravel beds $(3 \mathrm{BCb}$ and $4 \mathrm{BCb}$ ) consist of limestone clasts up to $10 \mathrm{~cm}$ diameter (clast-supported), with pore fillings of silt. The 4BCb horizon contains discontinuous pods of weathered volcanic ash and limestone clasts that disintegrate upon disturbance. The bedding follows the slope of the present intermound land surface for about two meters from the upslope end of the trench, at which point the $3 \mathrm{BCb}$ horizon pinches out. The $4 \mathrm{BCb}$ gravel bed forms the floor of the trench and is continuous for the entire length. A weak soil (indicated by color) developed in each of the gravel beds prior to burial.

Loess mixed with underlying gravels comprises the $2 \mathrm{BC}$ soil horizon. This unit dips at a steeper angle in the segment where the $3 \mathrm{BCb}$ pinches out, and disappears at about $800 \mathrm{~cm}$. Surficial soils have silt loam textures, typically $<5 \%$ gravels, and subangular blocky structure. Clay content increases to $\approx 30 \%$ at $10 \mathrm{~cm}$ depth (Bk1 and $\mathrm{Bk} 2$ ), and structure changes from massive in the A horizon to subangular blocky in the $\mathrm{Bk} 1$ and $\mathrm{Bk} 2$. Soil horizons described above are laterally continuous to $350 \mathrm{~cm}$, at which point they are disrupted. From $300-350 \mathrm{~cm}$, the substrate is a gravelly silt loam with no distinct horizonation or continuity with the profiles on either side. The disturbance does not appear to be recent; the soil is not loose and boundaries are not distinct as in most krotovina observed during the study. A weak structure in the upper part is either a disturbed continuation of the $\mathrm{Bk} 1$ horizon or a more recent accumulation of calcium carbonate. The origin of this disrupted segment is unclear.

The soil between $350-800 \mathrm{~cm}$ is bioturbated, but soil horizons are recognizable and can be followed laterally. The $\mathrm{A}, \mathrm{Bk} 1$, and $\mathrm{Bk} 2$ units are fairly continuous to $500 \mathrm{~cm}$, at which point the structure (sbk) in the $\mathrm{Bk} 1$ changes from moderate to very strong development. Underlying the $\mathrm{Bk} 2$ is a $\mathrm{BC}$ horizon developed in the reworked loess. The loess thickness is increased at this point due to the pinching out of the $3 \mathrm{BCb}$ gravel bed. Thus, the top of the $\mathrm{BC}$ parallels the ground surface, and the bottom parallels the dipping surface of the gravels (Figure 5). Gravel content in the $\mathrm{BC}$ is $\approx 5 \%$, and $\approx 10 \%$ in the underlying $2 \mathrm{BC}$. 
From 800-1170 cm, well within the surficial expression of the mound, the soils reflect significant bioturbation. The $\mathrm{A}, \mathrm{Bk} 1, \mathrm{Bk} 2$ and $\mathrm{BC}$ units are largely destroyed and mixed, disrupting lateral correlation with soil profiles on either side of the zone. Many remnants of the $\mathrm{Bk} 2$ are recognized, but have slumped to deeper positions within the mixed soils. This slumping is observed on both sides of the bioturbated zone (Plate 3). The BC unit is highly bioturbated, powdery, and loose, with numerous pockets of organic matter and scat. Gravels within the disturbed zone are at various orientations with respect to shape and position of calcium carbonate coatings, indicating reorientation of the gravels since deposition and soil formation. An incipient soil has developed within this bioturbated zone. A discontinuous $A$ horizon can be traced laterally to about $900 \mathrm{~cm}$ (close to the mound center). Bw and Bw2 horizons are recognizable within the mixed soils above the $\mathrm{Bk} 2$ remnants. The $\mathrm{Bw}$ is massive with a loose dry consistence, and the Bw2 has a weak, coarse-to-very coarse subangular blocky structure and slightly hard dry consistence. Color changes indicate movement and accumulation of calcium carbonate in the Bw2 horizon.

The mound soil on the downslope side of the central disturbed area, $(1170-1400 \mathrm{~cm})$ has the same horizon sequence as the mound soil on the upslope side of the central disturbed area. The surface layer is largely disturbed, probably by mammal activity, with an intermittent granular A horizon in șome locations. The Bk1 and $\mathrm{Bk} 2$ horizons have a strongly developed subangular blocky structure near the disturbed zone. Starting at $1350 \mathrm{~cm}$ (within the mound), the $\mathrm{Bk}$ is subdivided into three units by differences in soil structure. This strong structural development . weakens toward the downslope intermound soil, so that a single Bk with uniform structure is identified starting at about $1700 \mathrm{~cm}$. The $\mathrm{Bk}$ there is overlain by a $\mathrm{Bw}$ and the intermittent $\mathrm{A}$ horizon. The $\mathrm{BC}$ horizon in the downslope mound and intermound position is very similar to that on the upslope side. The structure is massive, dry consistence is loose to slightly hard, and the sediment is only weakly altered by pedogenesis. A short segment in the BC from $1230-1250 \mathrm{~cm}$ developed a distinct fabric after the trench had been open for several weeks. The fabric is expressed as a series of open cracks oriented N30W. A similar fabric was observed in the Bk2. horizon at $1210 \mathrm{~cm}$.

Three prominent cracks were observed in the soils at $710 \mathrm{~cm}, 1210 \mathrm{~cm}$, and $1380 \mathrm{~cm}$ (Plate 4). All three cracks dip off vertical with the top end further downslope. The cracks at 1210 and $1380 \mathrm{~cm}$ extend from the surface to the top of the gravels. A distinct soil fabric with ped faces parallel to the orientation of the crack was observed in the $\mathrm{Bk} 2$ horizon proximal to the crack at $1210 \mathrm{~cm}$. Limestone clasts were rotated into the cracks, and for a narrow (several $\mathrm{cm}$ ) zone in the soil proximal to the cracks. The origin of the cracks is' unclear, and there is no specific evidence to relate them to mound forming processes. A visiting researcher noted their similarity to soil cracks developed as a result of ground motion during seismic events (M.J. Bartholomew, personal communication, 1994):

\section{MFM2X}

8MFM2X was trenched at right angles to 8MFM2, oriented across the slope. The trench intersected $8 \mathrm{MFM} 2$ at the $1200 \mathrm{~cm}$ position (within the central disturbed zone). At the $1300 \mathrm{~cm}$ position within 8MFM2X (the end closest to 8MFM2) the surface soils reflect the mixing and weak soil development (mixed, discontinuous $\mathrm{A}$ and $\mathrm{Bw}$ ) seen in the central disturbed zone of the main trench. 


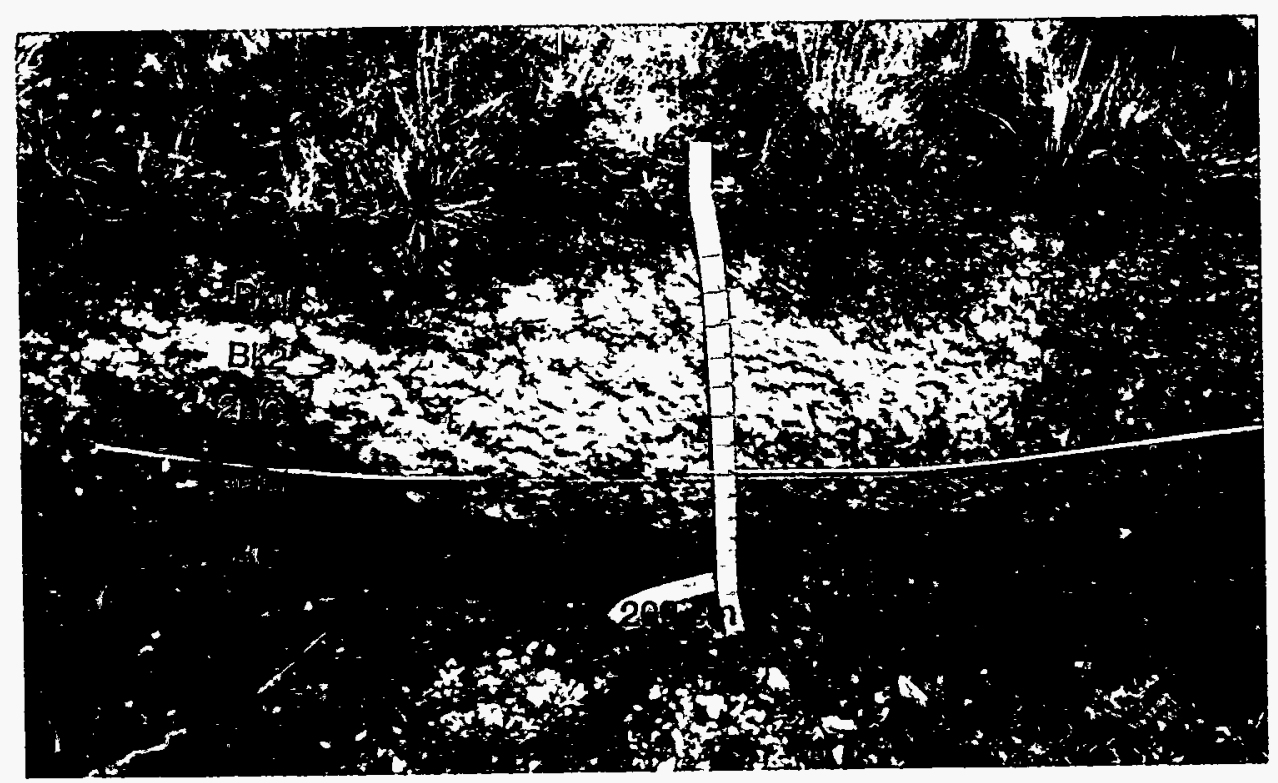

Plate 2 Intermound soil on the left side of 8MFM2

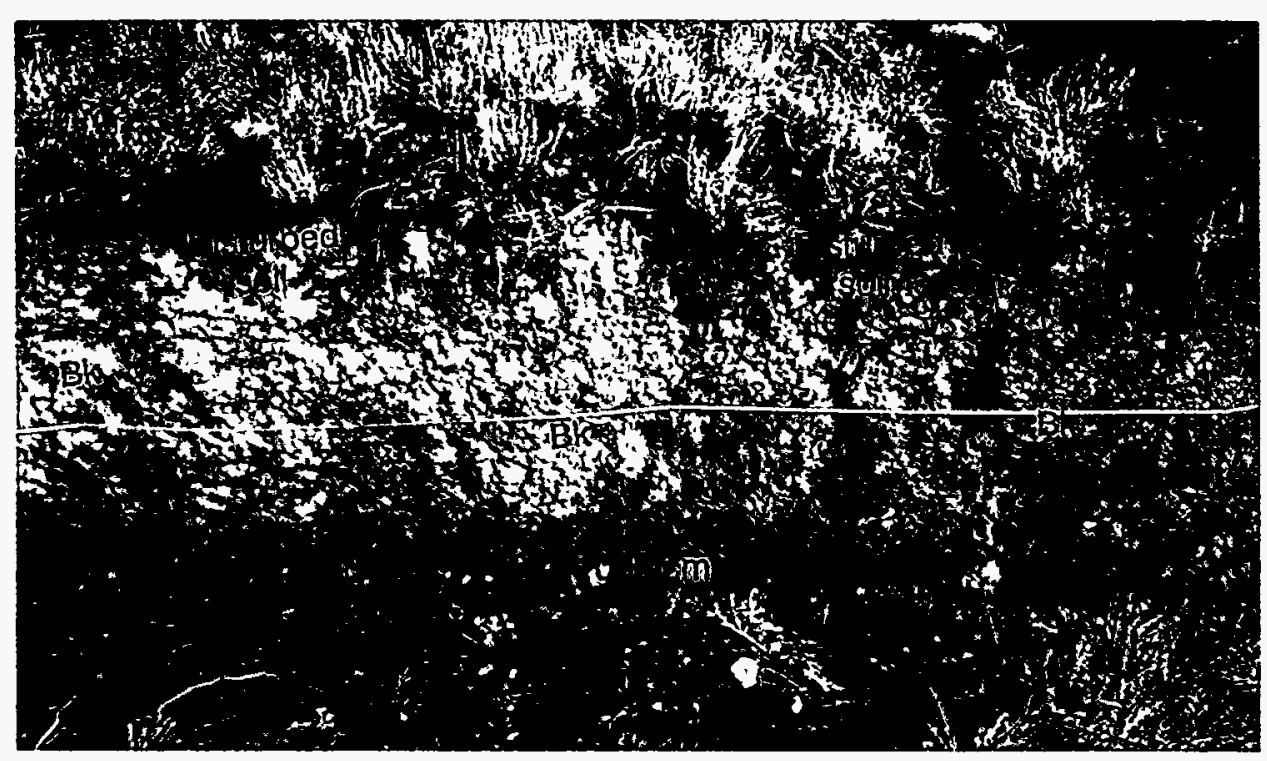

Plate 3 Central disturbed section of 8 MFM2. 


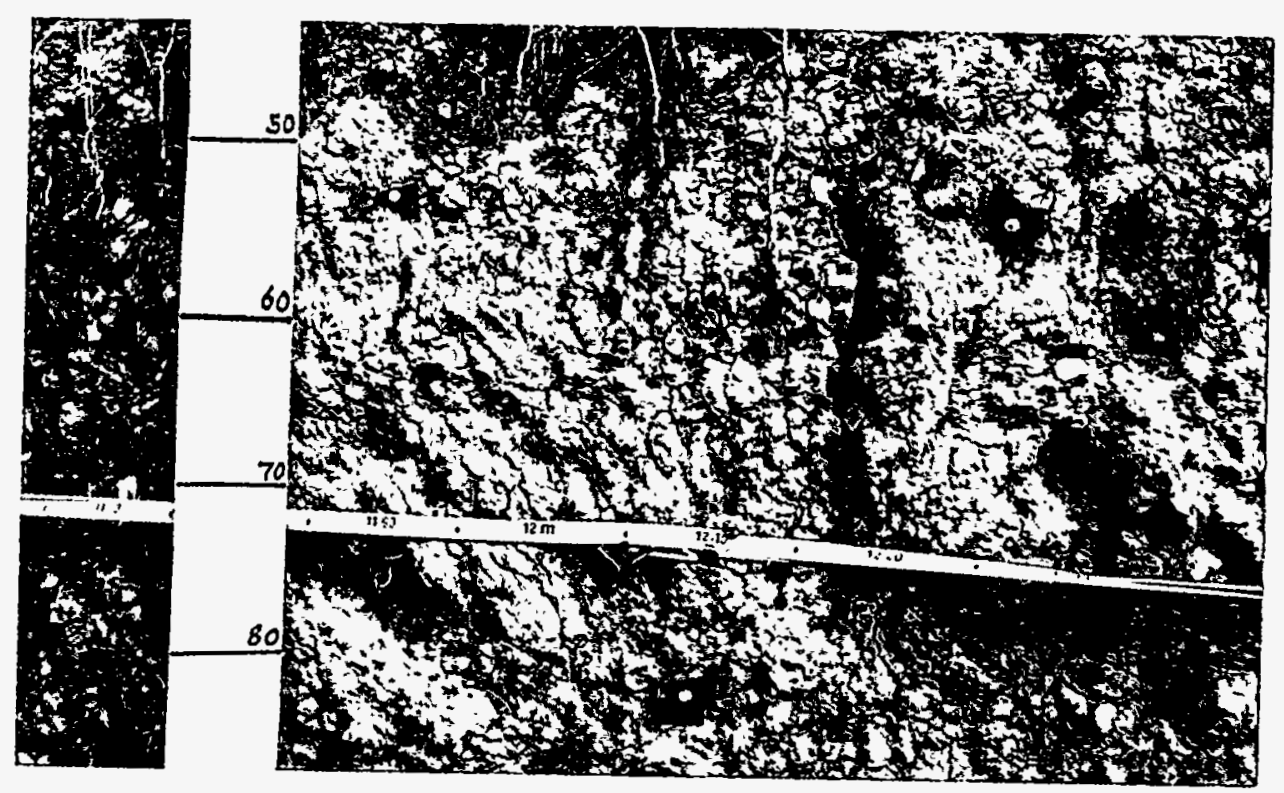

Plate 4 Soil crack in 8MFM2. 
The Bk units of the older soil are present, although greatly disturbed by bioturbation. The $\mathrm{BC}$ is correlative with the $\mathrm{BC}$ in the main trench, as is the basal gravel (4BC). As with the downslope side of the main trench, the soil development outside the disturbed zone begins to weaken outward from the mound. The two Bk units become one BK of uniform structure, eventually weakening to a Bw horizon. The silty sediments overlying the gravels thin considerably toward the intermound, probably due to erosion within a drainage channel.

Interpretation. The mound trenched as 8MFM2 and 8MFM2X formed in reworked loess deposited on an undulating paleosurface of alluvial fan gravels. Loess was deposited in pulses during the Bull Lake glaciation (mapped as af3 by Scott, 1982), was subsequently altered by slopewash processes and pedogenesis, and was deeply incised by erosion. A thin layer of Pinedale age loess was then deposited over the surface. At 8MFM2, gravel beds near the top of the paleosurface thin and pinch out downslope, forming a one-sided "bowl" shape.

The gravel/silt contact impedes the downward migration of water by forming a capillary barrier at the point where the hydraulic conductivity $(K)$ changes (silt = low $K$, gravel = high $K$ ). Water entering the system from the surface spreads both laterally and vertically in the silt. The water percolates into the underlying gravel after the silt is saturated and the capillary pull between the silt and gravel is equal. During mound formation, the overlying loess was probably at or near saturation. This water was available to migrate to the downward moving freezing front and form a series of rhythmic ice lenses. The growth of these ice lenses resulted in the heaving of surficial sediments.

Pedogenesis in the surficial sediment is similar to that observed in Pinedale age loess which required $10,000-15,000$ years to develop. The surficial soil in 8MFM2 is continuous across the mound/intermound boundaries with no apparent segregations or disruptions caused by growth of ice lenses. Horizons generally follow the present land surface. Structure development in the Bk horizons is stronger in the mound compared to the intermound. This is possibly due to enhanced eluviation of clays through loose surficial sediments, but it is not known if it was caused by the freezing process.

The prominent cracks developed at three locations within the mound are not diagnostic of frost activity and may relate to disruption by seismic shaking. The disturbed section in the intermound between $300-375 \mathrm{~cm}$ is puzzling, but there is no evidence (such as shape or orientation of soil fabrics) to suggest formation of an ice wedge or other frost related structure. It is most likely an older krotovina, similar to, but much less extensive than the disturbance in the central part of the trench. The soils in the interior of the mound have been strongly disrupted by bioturbation. Development of a weak soil in the bioturbated sediment (Bw1 and Bw2) suggests this activity has probably been ongoing for hundreds of years or more.

\section{MFM4}

8MFM4 is located on the northern flank of Eight-Mile Fan (mapped as af2 by Scott, 1982) in a topographically lower position than 8MFM2 (Figure 4 and Plate 1). The mound is less than $30 \mathrm{~cm}$ in height with indistinct edges grading imperceptibly into the intermound. The mound is easily recognized by the increased density and height of sagebrush species. Evidence of mammal activity is visible on the surface in the form of unconsolidated spoils. Figure 6 (foldout in 
envelope) is a cross section of the 8MFM4 trench wall. The mound was trenched in a northerly, downslope direction, with the vertical wall facing east. All profile positions were measured from the left (upslope) end of the trench.

The upslope intermound soil profile $(0-220 \mathrm{~cm})$, is expressed as an $\mathrm{A}, \mathrm{Bw}, \mathrm{Bwk}$, and $2 \mathrm{Bk}$ horizon sequence (Plate 5). The soil is developed in reworked loess overlying alluvial fan gravels (2Bk). The gravels are composed of limestone pebbles and cobbles. Interstitial pores are filled with silt. The gravels are firmly cemented by calcium carbonate, and have $<1 \mathrm{~mm}$ thick caliche rinds. Rinds at the base of the trench have a faint red color similar to that observed in the Bkqmb horizon (buried soil) in RWMCM1 (described below). The gravel beds dip 24-28 degrees in the upslope direction, but the paleosurface formed by erosion of the gravels follows the contour of the present land surface.

The reworked loess overlying the gravels has silt loam textures and up to $10 \%$ gravel content in the intermound increasing to $20 \%$ in the mound. Gravels in the loess are randomly oriented with respect to shape, but caliche coats are mainly on the bottom of clasts. Dry consistence ranges from loose to slightly hard, and subangular blocky structure is weak to moderately developed. All horizons effervesce, with reaction increasing below the A horizon. The basal gravel beds extend to the $370 \mathrm{~cm}$ position, with disturbed zones from $220-250 \mathrm{~cm}$ and again from $280-370 \mathrm{~cm}$. In the disturbed zones, the gravels lose the strong calcium carbonate cement, but still strongly effervesce. The interstitial silt is loose, and sloughs easily from the trench wall. These disturbed zones begin just outside the surficial expression of the mound/intermound boundary and extend into the mound. At $370 \mathrm{~cm}$, the basal gravels are truncated and are replaced by a thickened gravelly silt unit in which a Bk horizon has formed.

The Bk and overlying $\mathrm{Bw}$ horizons continue laterally to the $600 \mathrm{~cm}$ position. The units have weak horizon development and slight variations in effervescence, structure, and gravel content. The surface horizons, $\mathrm{A}$ and $\mathrm{AB}$, are laterally discontinuous, disturbed by active surficial processes.

From $600-830 \mathrm{~cm}$, the soil profile is largely obliterated by bioturbation (Plate 6). The gravelly silts are loose and soil horizons (as described previously) destroyed. Gravel content is $20 \%$ throughout. Orientation of gravels is random with respect to both shape and position of caliche rinds, indicating rotation from their original depositional positions. Many recent krotovina occupy the zone, and nests, open tunnels, and concentrations of scat are present. Slight changes in consistence and effervescence indicate continued leaching of calcium carbonate and weak soil development in the disturbed sediments. A distinct segment of bedded gravels occurs within this disturbed zone from $725-745 \mathrm{~cm}$. These gravels are interpreted to be a remnant of the $2 \mathrm{Bk}$ gravels which may have extended to this position prior to disturbance by mammals.

At $830 \mathrm{~cm}$, the basal gravel unit (2Bk) is in-place and undisturbed (Plate 7). The gravels are strongly cemented, still dipping upslope as do those on the left side of the trench. A gravelly silt, with weakly developed (and bioturbated) Bw and Bk horizon overlies the gravels. These sediments thin in the downslope direction to a thickness of about $40 \mathrm{~cm}$ at the right end of the trench. The bioturbation in the Bw horizon decreases with distance away from the zone of prominent mammal activity. The underlying $\mathrm{Bk}$ horizon is less disturbed, and as the sediments thin toward the downslope intermound, the $\mathrm{Bw}$ and $\mathrm{Bk}$ horizons are difficult to delineate. The surface A horizon is discontinuous probably reflecting mammal activity. 


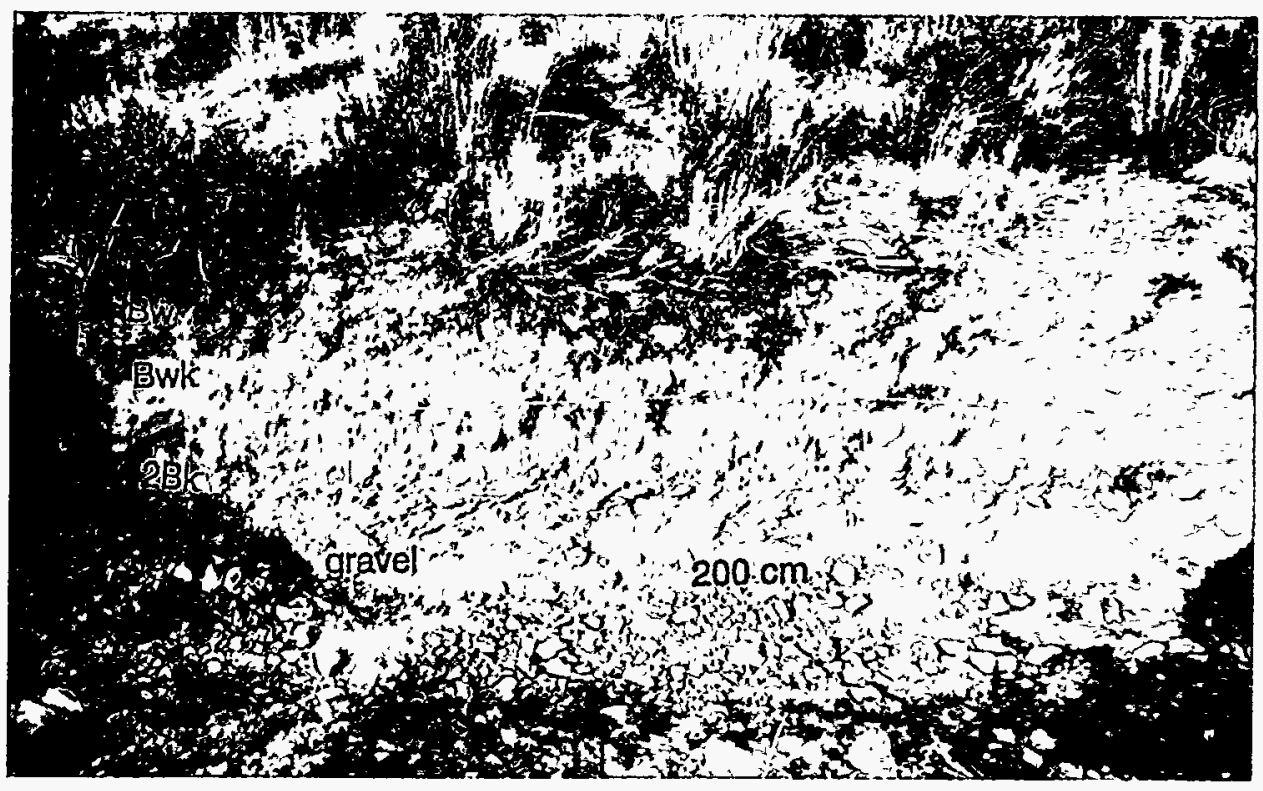

Plate 5 Intermound soil position at left end of trench 8MFM4.

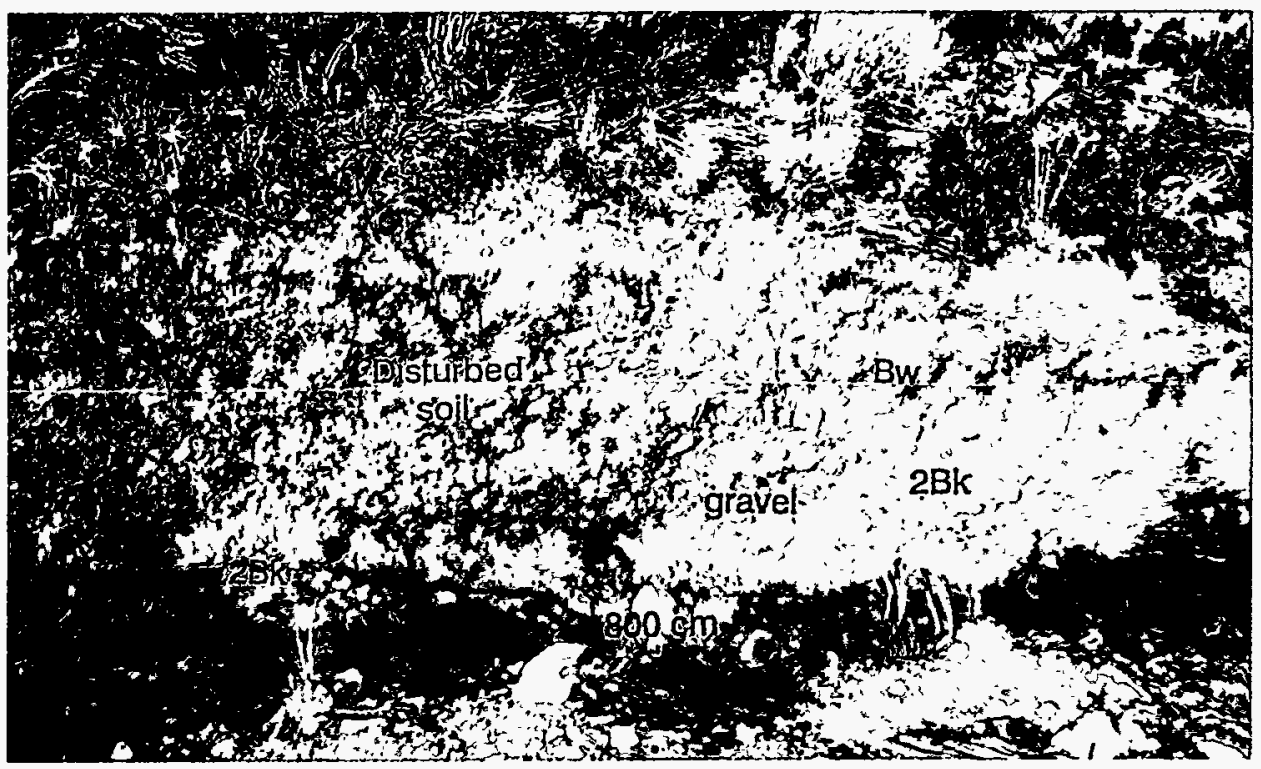

P1ate 6 Disturbed soil in the central section of 8MFM4. 
- 


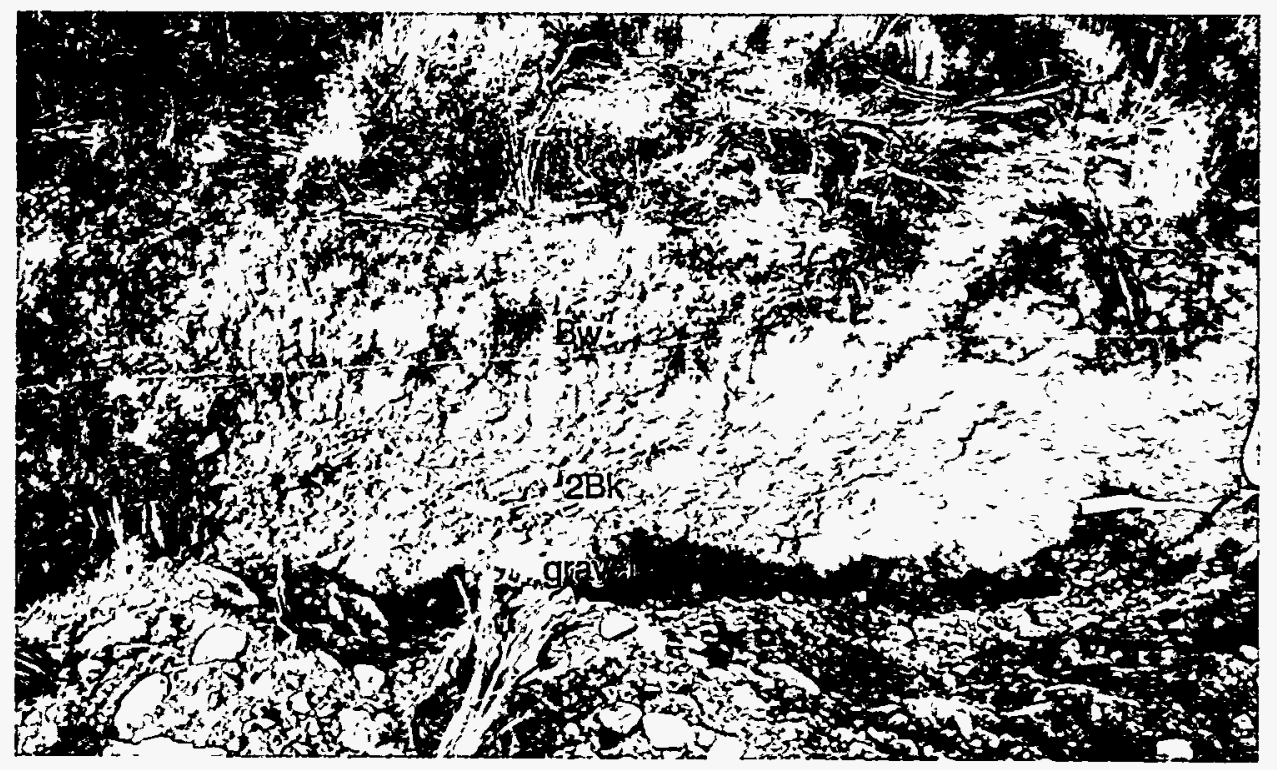

Plate 7 Soil on the right side of trench 8MFM4, showing the basal gravels. 
-

- 
Interpretation. The history of mound development at this site is similar to that at 8MFM2, although 8MFM4 is smaller, has lower relief, and is less stratigraphically complex. The sediments are thinner, and the surface on which the mound formed is covered only with Pinedale age loess. The mound floor is comprised of alluvial gravels (2Bk) on which formed a channelized paleosurface. This surface was buried by loess, reworked by slope processes. Differences in hydraulic conductivity between the gravels and overlying silty soils acted as a barrier to infiltration of water to the deeper substrate. The silty sediments were susceptible to heaving by the growth of ice lenses in a system open to the migration of water to the freezing front. Gravels from the lower gravel beds were heaved into the surficial sediments during the mound forming process. The position of caliche coats on the bottoms of these rotated gravels indicates that heaving occurred prior to pedogenesis of the Holocene soil. Later activity by burrowing mammals largely destroyed the central section of the mound. This mammal activity is ongoing.

\section{Fluvial terraces}

\section{Introduction}

Rathburn (1991) identified four distinct alluvial deposits of the Big Lost River (Plate 8). The two oldest deposits, $\mathrm{Qa}$ and $\mathrm{Qb}$, both support mounded microtopography. The oldest deposit, Qa, forms a distinct surface four to five meters above the present river channel. The Qa sediments farthest from the south side of the river thin against an underlying basalt flow which outcrops as a low ridge. The Qa sediments closest to the river were eroded to form a distinct bench. Deposition of younger sediments $(\mathrm{Qb})$ formed a second terrace inset to the $\mathrm{Qa}$ surface. The elevation difference between these two terraces is one to two meters. The Qa is composed of gravel with matrix support of sand and silt. Rathburn (1991) interprets clast-supported lenses as the result of rapid deposition from a turbulent flood flow. Faint meander scars are visible on the surface, especially on aerial photographs. Rathburn (1991) interprets the Qa deposit and its surface as a flood delta or fan deposited during the lateral expansion of glacial-outburst floodwaters leaving the constriction of Box Canyon. Scott (1982) mapped the unit as part of the Upper Pleistocene age deposits of mainstreams, however at that time (1982) evidence of the glacial-outburst flooding was not recognized. Mound distribution on the Qa surface in the trench locations appears strongly curvilinear along meander scars (Plate 8).

The $\mathrm{Qb}$ deposit is composed of sand and silt flood overbank deposits underlain by interstratified gravels similar to the $\mathrm{Qa}$ gravels. The $\mathrm{Qb}$ surface is generally lower than the $\mathrm{Qa}$ surface, from 2.5 - 5 meters above the present river channel. Gravels were deposited on migrating point bars after incision into the older Qa deposit. Mounds on this surface are indistinct and sparse, occurring primarily in curvilinear patterns overprinting the faint meander scars (Plate 8). They were not mentioned by Nace et al. (1956).

Mounds on both the $\mathrm{Qa}$ and $\mathrm{Qb}$ surfaces are largely circular in plan view, $<0.5 \mathrm{~m}$ in height, and generally uniform in diameter. Mounds are never found touching and are generally separated by several mound diameters. Mound edges are gradational with intermound areas, but can be identified by changes in the surface and vegetational differences. The intermound surface has developed a gravel pavement (in areas between vegetation clumps) up to 90\% gravel in a single layer over a sandy substrate (Plate 9). The mound surface has only 30 - 
$50 \%$ gravel resting on a sandy substrate. Sagebrush on the mounds is both taller and denser than on the intermound. The amount of dead sagebrush on the mounds is notable, but the reason for that was not investigated. The mounds also support more annual species, and on the $\mathrm{Qb}$ surface, more false globe mallow. Nace et al. (1956) mapped mounds on the Qa surface and suggested the landforms were related to permafrost during the Upper Pleistocene.

\section{BLRM2}

BLRM2 is located on the Qa surface $0.2 \mathrm{~km}$ south of the river channel and $0.6 \mathrm{~km}$ east of the nearest basalt outcrop (Figure 7 and Plate 8). The mound is circular in plan view and $13 \mathrm{~m}$ in diameter. The mound is vegetated with big sage, rabbitbrush, false globe mallow, prickly pear cactus, and annual mustards. The intermound is vegetated with big sage, rabbitbrush, needle-andthread grass, Indian paintbrush, basin wildrye, Indian ricegrass, and other wildflower species. The density and size of big sage, mustard, and rabbitbrush on the mound is greater than that in the intermound; however, the number of species is greater in the intermounds. A large $(\approx 80 \mathrm{~cm}$ diameter), rounded basalt boulder, a glacial-outburst flood erratic, sits on the intermound surface close to the trench.

Figure 8 (foldout in envelope) is a log of the BLRM2 trench wall. The trench was oriented NE-SW, parallel to the predominant wind direction, and with a southeast vertical exposure. The trench floor was bedded alluvial gravels of mixed lithologies, pinching out toward the center of the trench, creating a concave upward surface.

The soils in this trench formed in flood overbank deposits overlying bedded alluvial gravels. The gravel content in the overbank deposits ranges from 5-20\%. Many of the gravels have caliche coats $1 \mathrm{~mm}$ or less in thickness. The intermound soils at the left end of the trench $(0 \mathrm{~cm}$ on profile) have an $\mathrm{A}, \mathrm{AB}, 2 \mathrm{Bw}, 2 \mathrm{Bk} 1,2 \mathrm{Bk} 2$, and $3 \mathrm{C}$ horizon profile (Plate 10). The $\mathrm{A}$ horizon is generally granular, loose, and discontinuous. The $\mathrm{AB}$ is loose, with a weak medium-to-coarse, subangular blocky structure. These two horizons formed in eolian sand, likely Holocene age. The $2 \mathrm{Bw}$ is slightly hard, with moderate, medium-to-coarse, subangular blocky structure. Both the $\mathrm{AB}$ and $2 \mathrm{Bw}$ horizons units exhibit depositional bedding. The 2Bk units are well developed, ranging from hard to very hard and with moderate to strong, medium-to-coarse, subangular blocky structure. The lowermost $3-4 \mathrm{~cm}$ of the $2 \mathrm{Bk} 2$ is very hard and white.

From $600-1150 \mathrm{~cm}$, the soil horizons are disrupted and strongly mixed by bioturbation (Plate 11). The sediments are loamy sand with 5-20\% gravel content which apparently increases with depth. Remnants of the Bk horizon are present across the zone. Fresh krotovina with abundant scat and other organic matter are common. Incipient pedogenesis has resulted in minor leaching of calcium carbonate forming two weak soil horizons in the mixed sediment. $\mathrm{A} \mathrm{Bw}$ has developed with weak, coarse subangular blocky structure. Below this, the Bwk has stronger effervescence and higher Munsell color value, indicating translocation and accumulation of calcium carbonate. Pedogenesis in the bioturbated zone has not progressed to the point where remnant $\mathrm{Bk}$ units have been affected. 


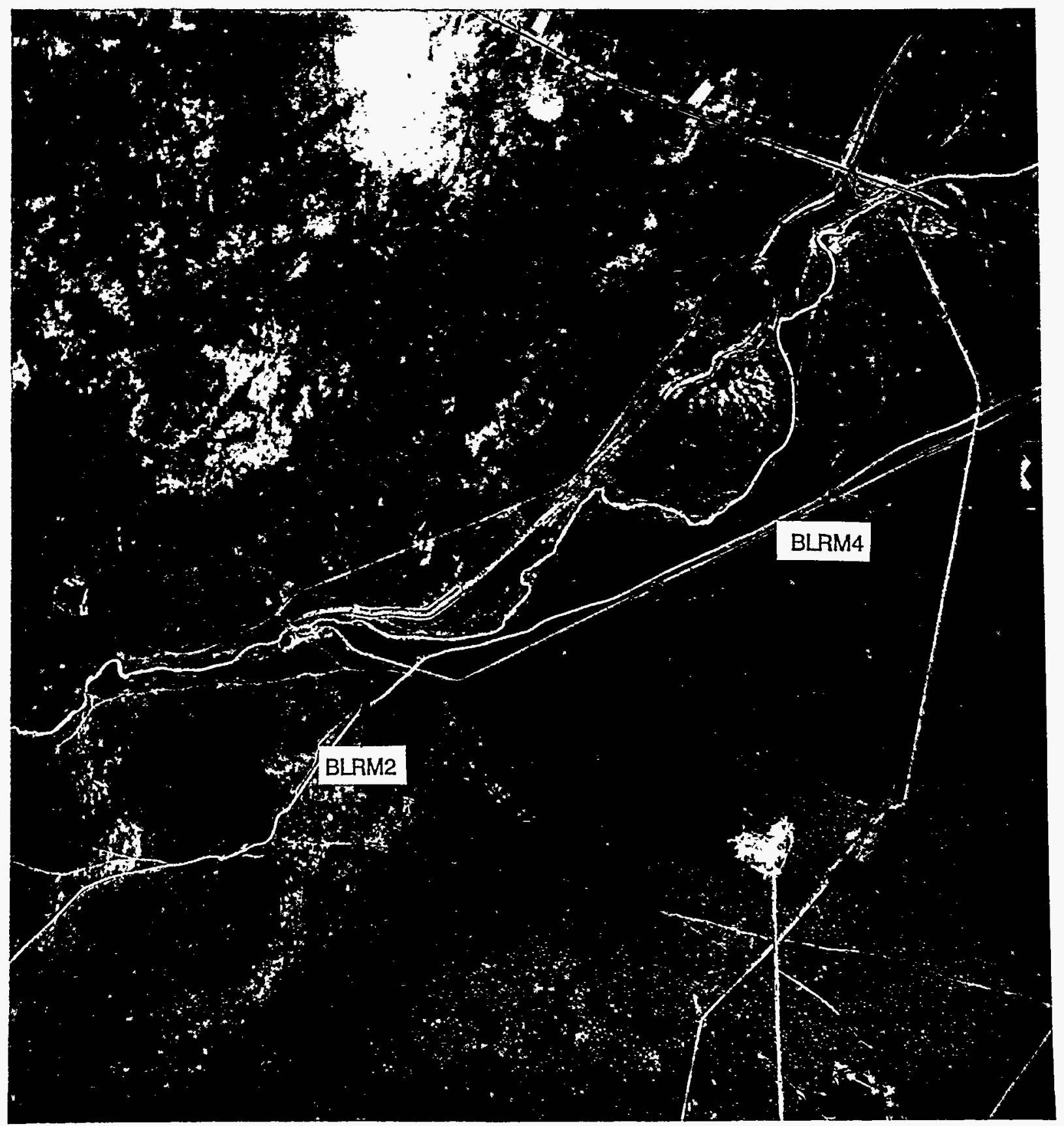

Plate 8 Aerial photograph of the Big Lost River showing the Qa and $Q \mathrm{~b}$ terraces and the locations of trenches BLRM2 and BLRM4. 


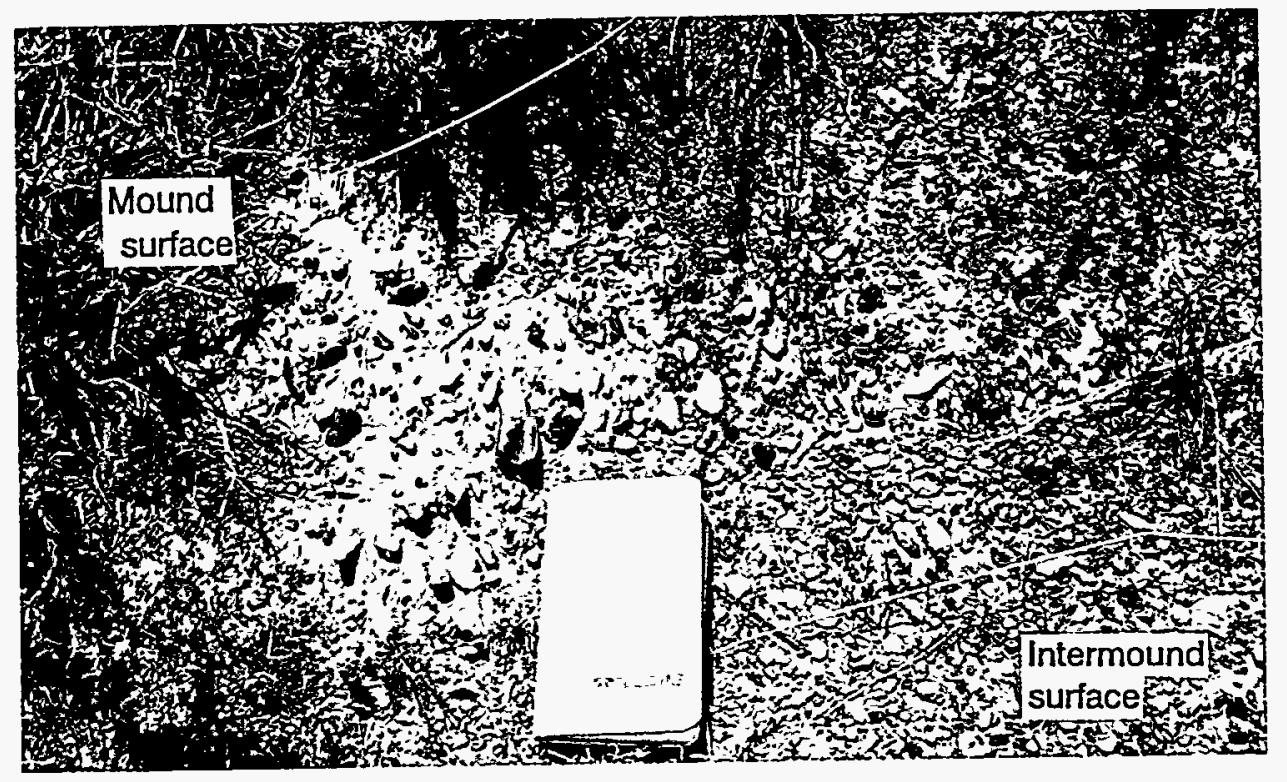

Plate 9 Photograph showing the difference in pavement between the mound and intermound surfaces. 


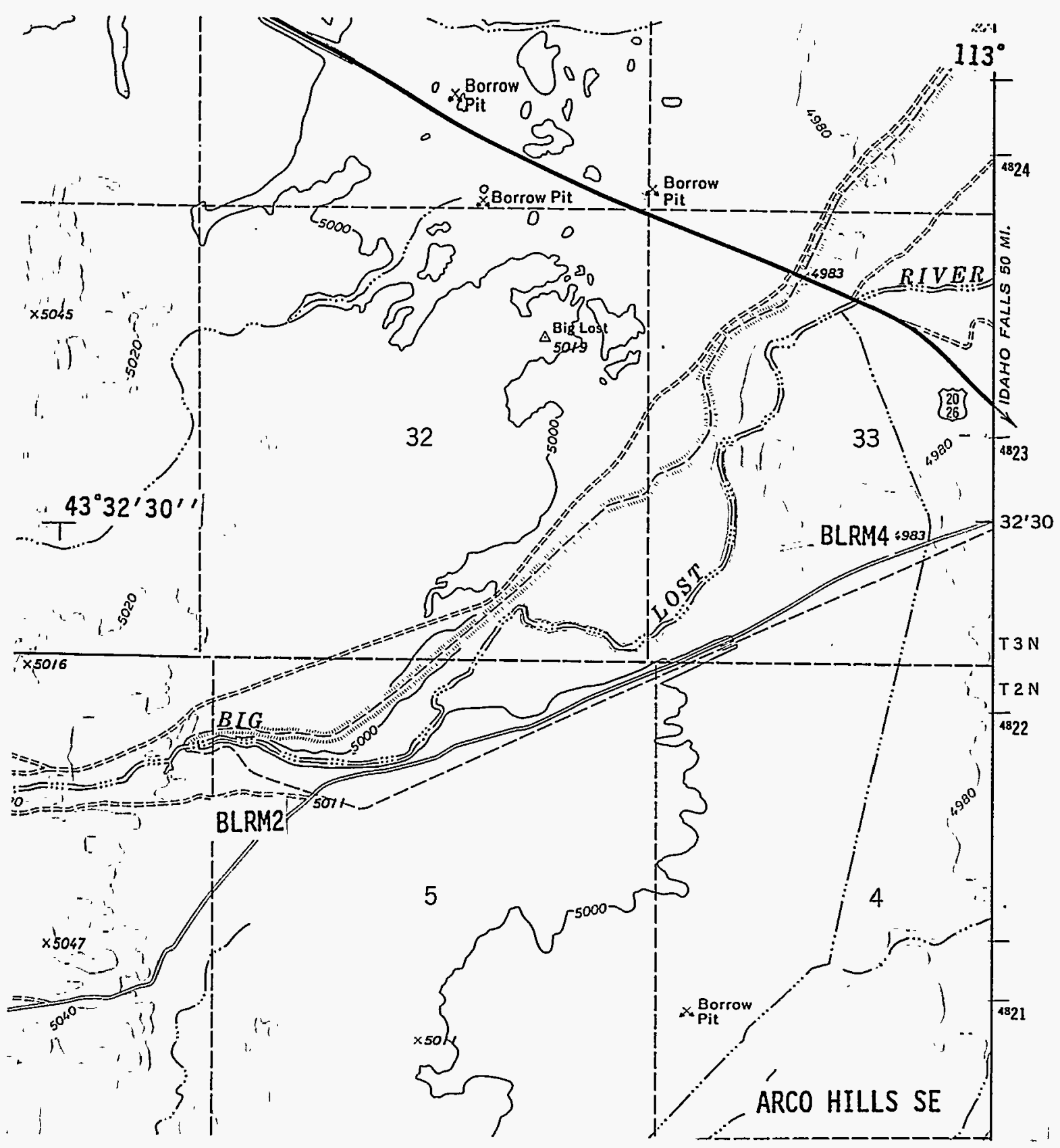

Figure 7 USGS 7.5 minute topographic map showing the location of BLRM2 and BLRM4. 


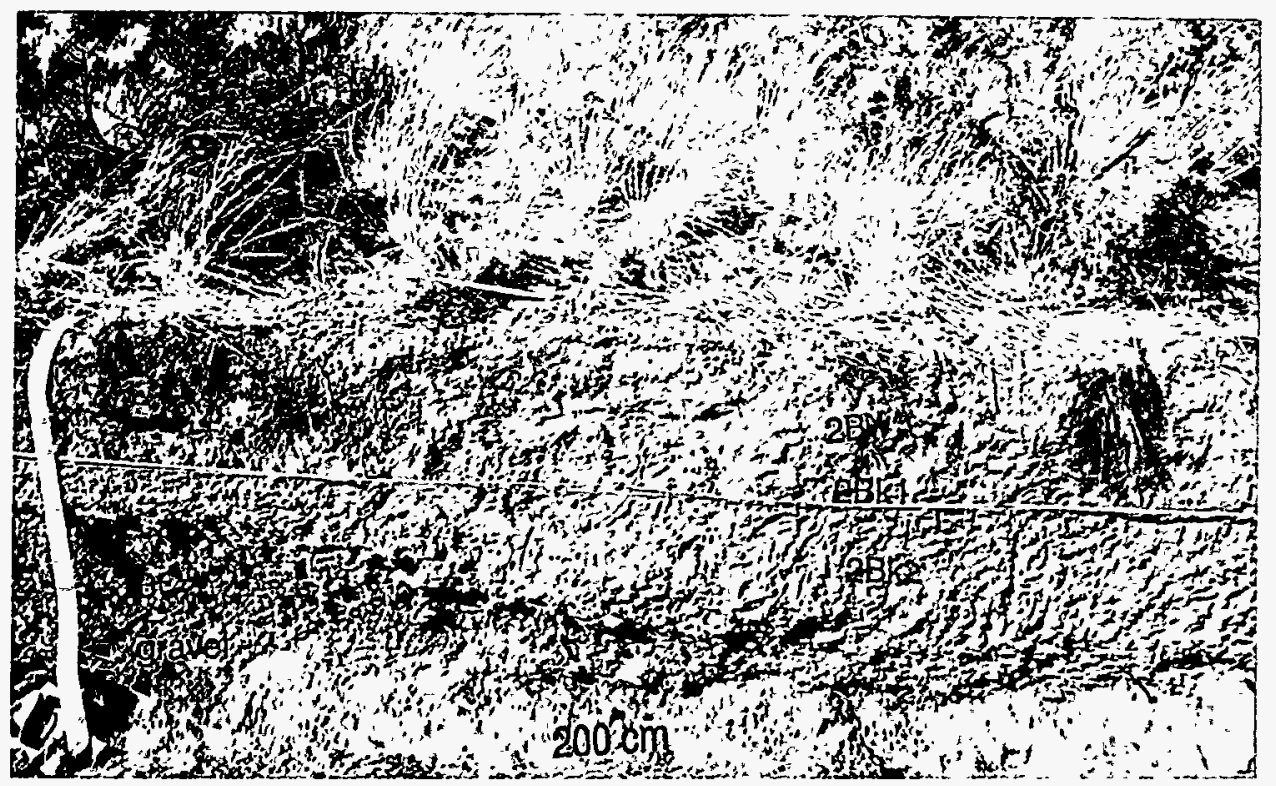

Plate 10 Intermound soils at the left side of BLRM2.

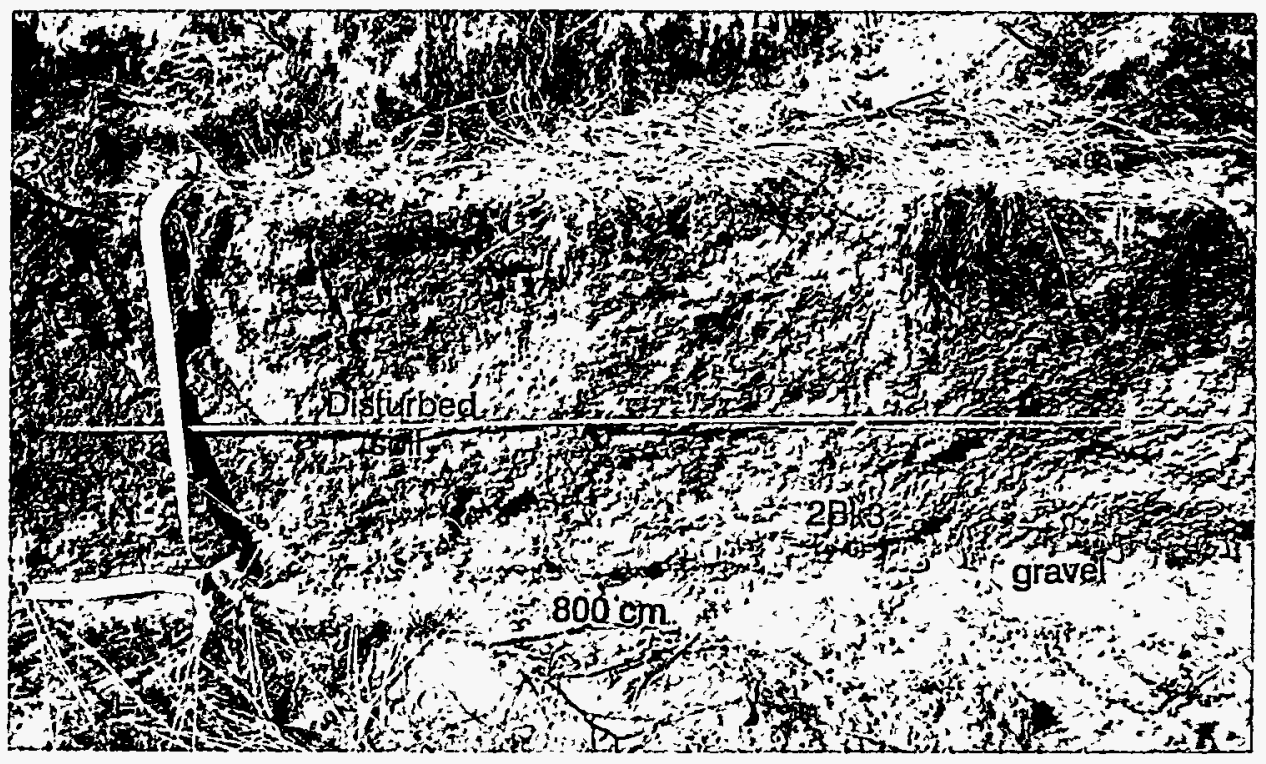

Plate 11 Disturbed soils in the central section of BLRM2. 
To the right of $1120 \mathrm{~cm}$, the soil is essentially the same as that on the opposite side of the disturbed zone. The soil parent material (overbank deposits) of the intermound soil is thinner on this end of the trench, such that carbonate accumulation occurred in the uppermost bedded gravels (3Bk2 and 3Bk3 horizons). Distinct vertical deposits of $\mathrm{CaCO}_{3}$ in the gravels result from the piping of moisture downward as it penetrates the capillary barrier formed by the difference in grain size between the two stratigraphic layers.

Interpretation. Abandoned meander scrolls on the Qa surface were filled with fine-grained sediments during flooding of the Big Lost River. Hydraulic conductivity differences between the basal gravels and the overlying fine-grained sediments resulted in sufficient moisture availability for the growth of ice lenses at a downward moving freezing front, and the subsequent heaving of surficial sediments. Pedogenesis occurred after heaving, as evidenced by the lateral continuity, with no disruptions, of soil across the mound/intermound boundaries. Additionally, the top of soil horizons laterally parallel the present ground surface, including the shape of the mound.

Fossorial rodents largely destroyed soil horizons in a central portion of the mound, leaving only . remnants of the original soil. Continued leaching of calcium carbonate in this zone has created a weak soil, which in turn contains younger krotovina. Eolian sands are continually transported across the area resulting in deposition and mixing of loose sand on and into the surficial horizons creating the weak and discontinuous $\mathrm{A}$ horizon and buildup of the $\mathrm{AB}$.

\section{BLRM4}

BLRM4 is located on the younger, lower $\mathrm{Qb}$ surface (Figure 7). The few mounds that are apparent on this surface appear to follow old meander channels (Plate 8). The mounds are low, and are distinguished by changes in density and height of sagebrush species, increased density of false globemallow, and change in the surface gravel density as described previously. The trench was dug in a northerly direction with the vertical wall facing west. The trench log is shown in Figure 9 (foldout in pocket).

The soil in this trench formed in a sandy loam or loamy sand, underlain by bedded alluvial gravels. The intermound profiles shown on Plates 12 and 13 are characterized by an $\mathrm{A}, \mathrm{Bw}, 2 \mathrm{C}$ profile with the $\mathrm{A}$ horizon discontinuous and formed mainly around vegetation. In nonvegetated areas, the surface horizon is a loose sand, capped with a gravel pavement. The Bw is a loamy sand with up to $35 \%$ gravel. It is up to $30 \mathrm{~cm}$ thick, exhibits a weakly developed subangular blocky structure, and generally does not effervesce with dilute hydrochloric acid. The $2 \mathrm{C}$ is crossbedded alluvial gravels with interstitial sand.

The soil in mound positions formed in thicker sediments than the intermound soil. The soil consists of an $\mathrm{A}, \mathrm{Bw}, 2 \mathrm{Bw}, 2 \mathrm{Bk} 1,3 \mathrm{C}$ horizon sequence (e.g., at $770 \mathrm{~cm}$ ). The $\mathrm{Bw}$ is formed in eolian sands deposited mainly on the upwind side of the mound. The A horizon has a moderate fine-to-medium grained granular structure. The $\mathrm{Bw}$ has a massive structure, parting to a weak medium-to-coarse subangular blocky structure. The $\mathrm{A}$ and $\mathrm{Bw}$ horizons do not effervesce. The $2 \mathrm{BW}$ and $2 \mathrm{Bk} 1$ horizons are comprised of sandy loam or silt loam with gravel content ranging from $5-20 \%$.

The gravels in the overbank deposits do not have caliche coats. The 2Bk1 unit has accumulated calcium carbonate and formed a moderate, medium subangular blocky structure. On 
the left side of the trench ( $260 \mathrm{~cm}$ profile), the $\mathrm{Bk}$ unit is divided into $2 \mathrm{Bk} 1$ and $2 \mathrm{Bk} 2$ horizons. The $2 \mathrm{Bk} 2$ has a harder dry consistence and more calcium carbonate accumulation than the overlying horizon. This unit pinches out at about $350 \mathrm{~cm}$. The $3 \mathrm{C}$ horizon is comprised of bedded alluvial gravels (designated $2 \mathrm{C}$ in the intermound). The gravels pinch out into the center of the mound forming the concave upward floor.

The central zone of the mound is disrupted by bioturbation (Plate 14), but to a lesser degree than observed in other trenches. Many large remnants of the $2 \mathrm{Bw}$ and $2 \mathrm{Bk} 1$ remain in place within the zone. Additionally, the surface sediments, which are completely mixed in most trenches, contain many peds of the $2 \mathrm{Bw}$. Most krotovina within this zone are fresh, and contain very loose sediment and abundant organic matter.

Interpretation. This mound formed where an abandoned meander channel was filled with finer-grained flood deposits from the Big Lost River. The surficial sediments heaved in response to the growth of ice lenses as in BLRM2. Pedogenesis resulted in a soil laterally continuous across the mound/intermound boundary, and following the contour of the mound. Eolian sand derived from local alluvial sources have been redistributed over the surface, burying the overbank deposits. Weak pedogenesis has continued in the eolian sand. Mammal activity has resulted in mixing of soil horizons within a narrow zone near the center.

\section{Loess-Over-Basalt Mounds}

\section{Introduction}

Much of the ESRP is blanketed by widespread loess deposited during periods of regional glaciation (Pierce et al., 1982; Forman et al., 1993). Loess thickness varies with geographic position, the number of discrete loess units present (older basalt flows are covered with more loess), and postdepositional erosional processes. Mounds formed in loess in many areas, but are not observed in very thin loess units over the youngest lava flows (e.g., Hell's Half Acre, or North and South Robbers flows), or in areas with numerous bedrock outcrops. Loess thickness data are sparse for most areas on the ESRP. The trenched sites were mapped by Scott (1982) as Upper to Middle Pleistocene silt and sandy silt (el2), with 30-75\% basalt outcrops, and maximum thickness to $3 \mathrm{~m}$ (1.5-2 $\mathrm{m}$ thickness common). The loess is nonbedded, or crudely bedded where reworked by slope processes.

\section{RWMCM1}

RWMCM1 is located near the base of a west-facing slope, which forms one margin of a shallow basin partially filled with loess, alluvium, and slopewash sediments (Figure 10 and Plate 15). Basalt outcrops approximately ten meters upslope of the mound. The mound grades imperceptibly into the upslope intermound, but forms a toe $\approx 0.5 \mathrm{~m}$ high on the downslope side. The mound and intermound vegetation both include sagebrush, rabbitbrush, grass, and cactus, however sagebrush on the mound is distinctly denser and taller (and a noticeable number are dead). Basalt clasts $<10 \mathrm{~cm}$ diameter are found on the mound and intermound surfaces. The RWMCM1 trench was oriented parallel to the maximum slope direction with the vertical wall facing south. Figure 11 (foldout in envelope) is a log of the RWMCM1 trench wall. The log was drawn using measured points of reference rather than photographic overlays. 


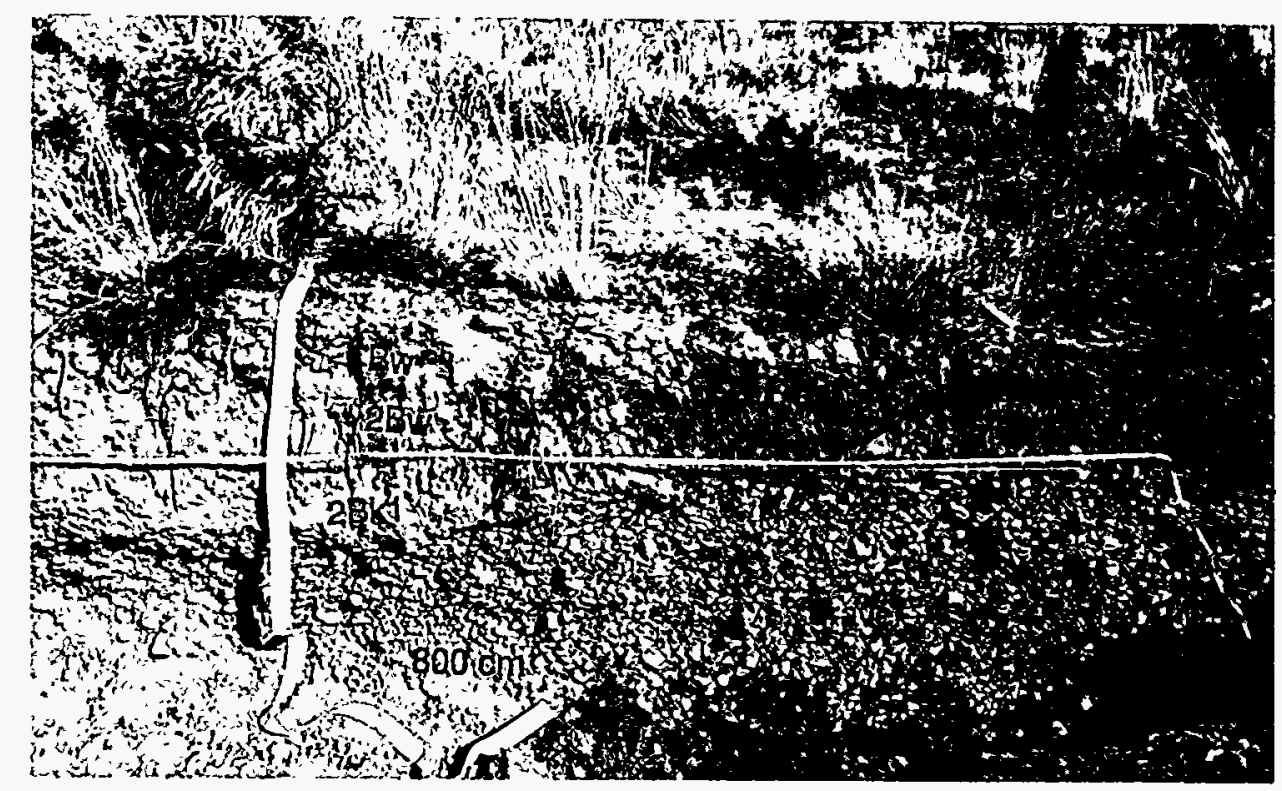

Plate 12 Intermound soil at right side of BLRM4.

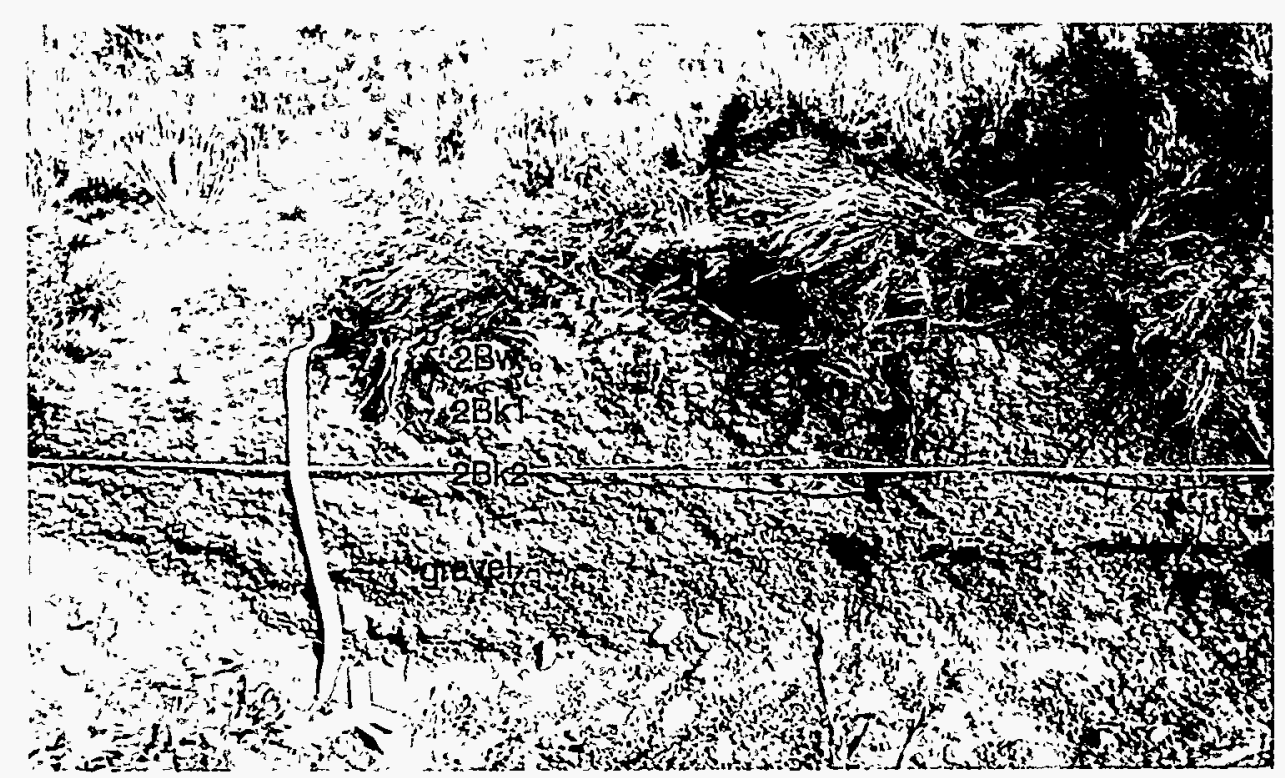

P1ate 13 Intermound soil at left side of BLRM4. 


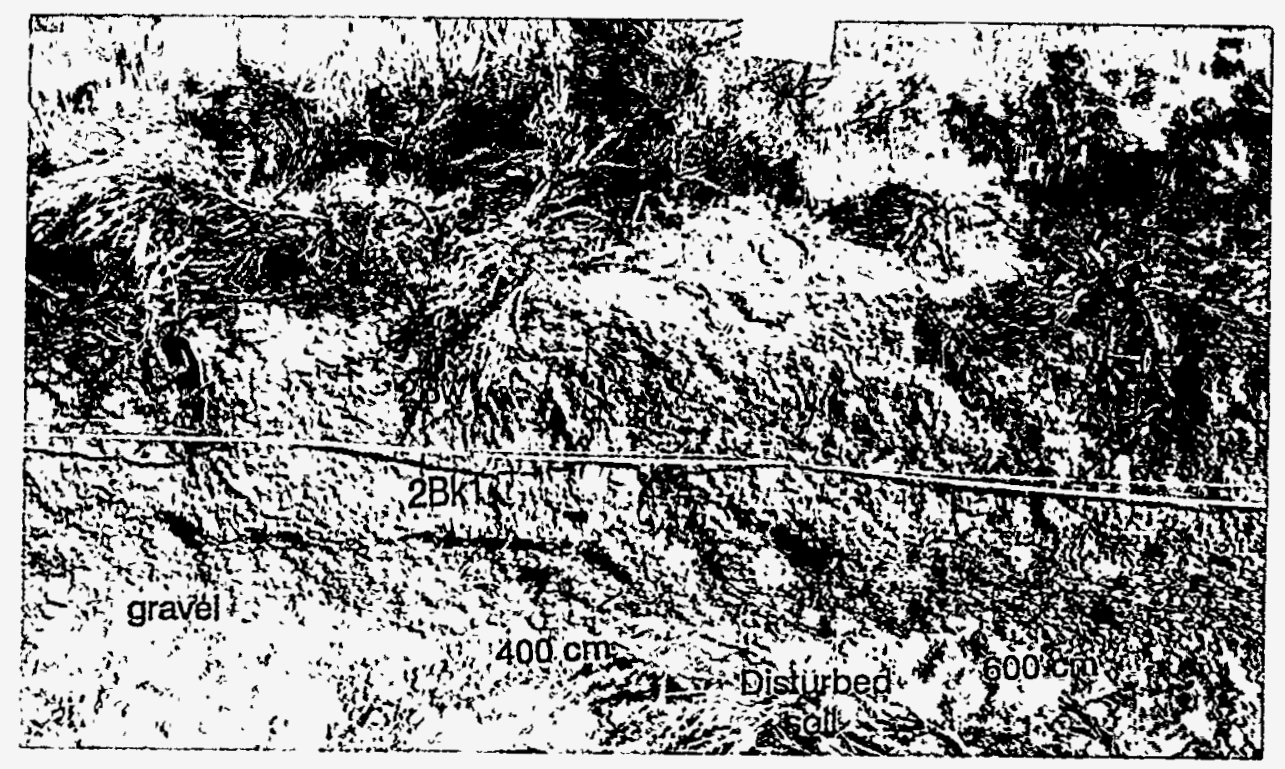

Plate 14 Central disturbed section in BLRM4. 


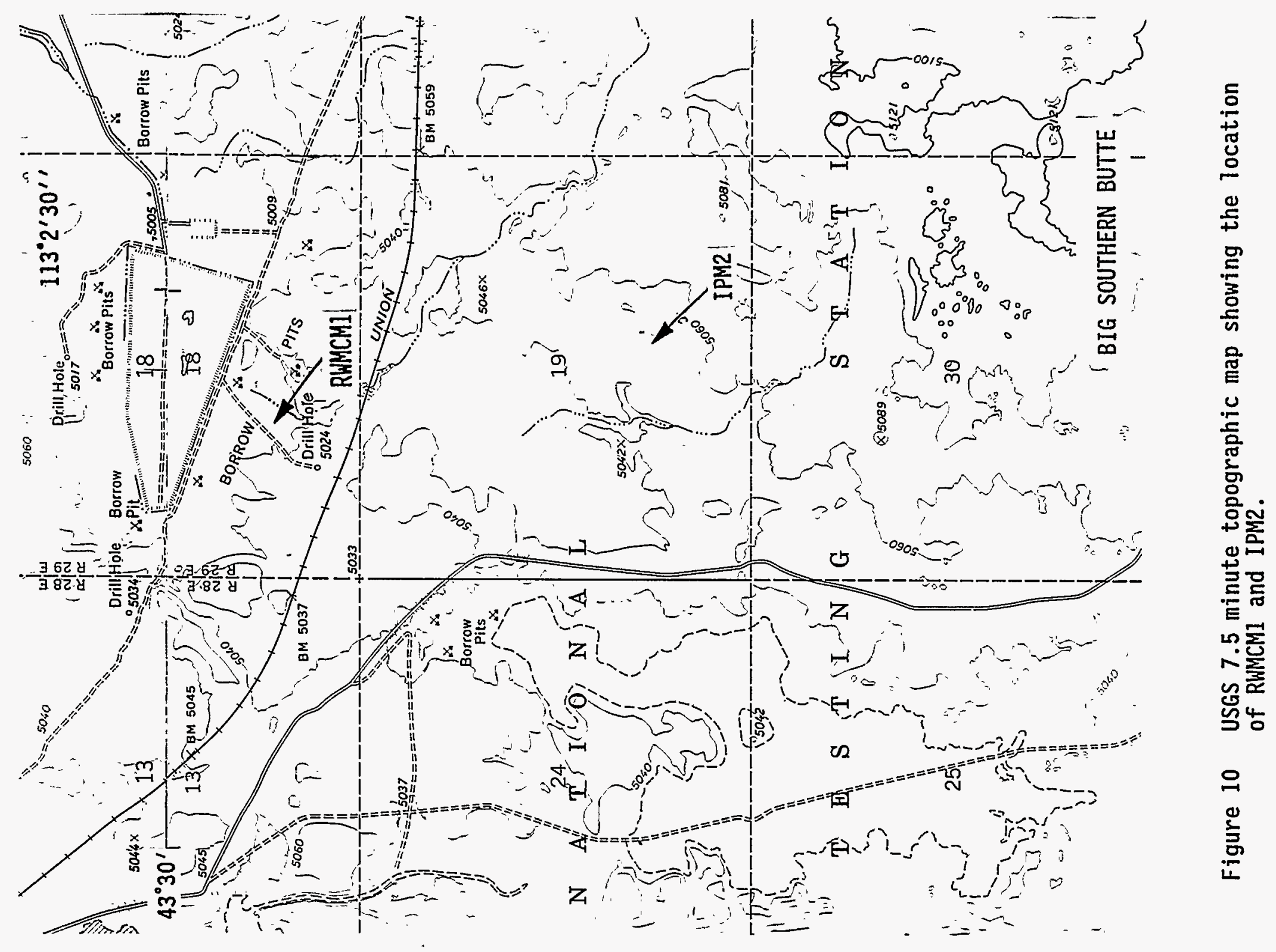




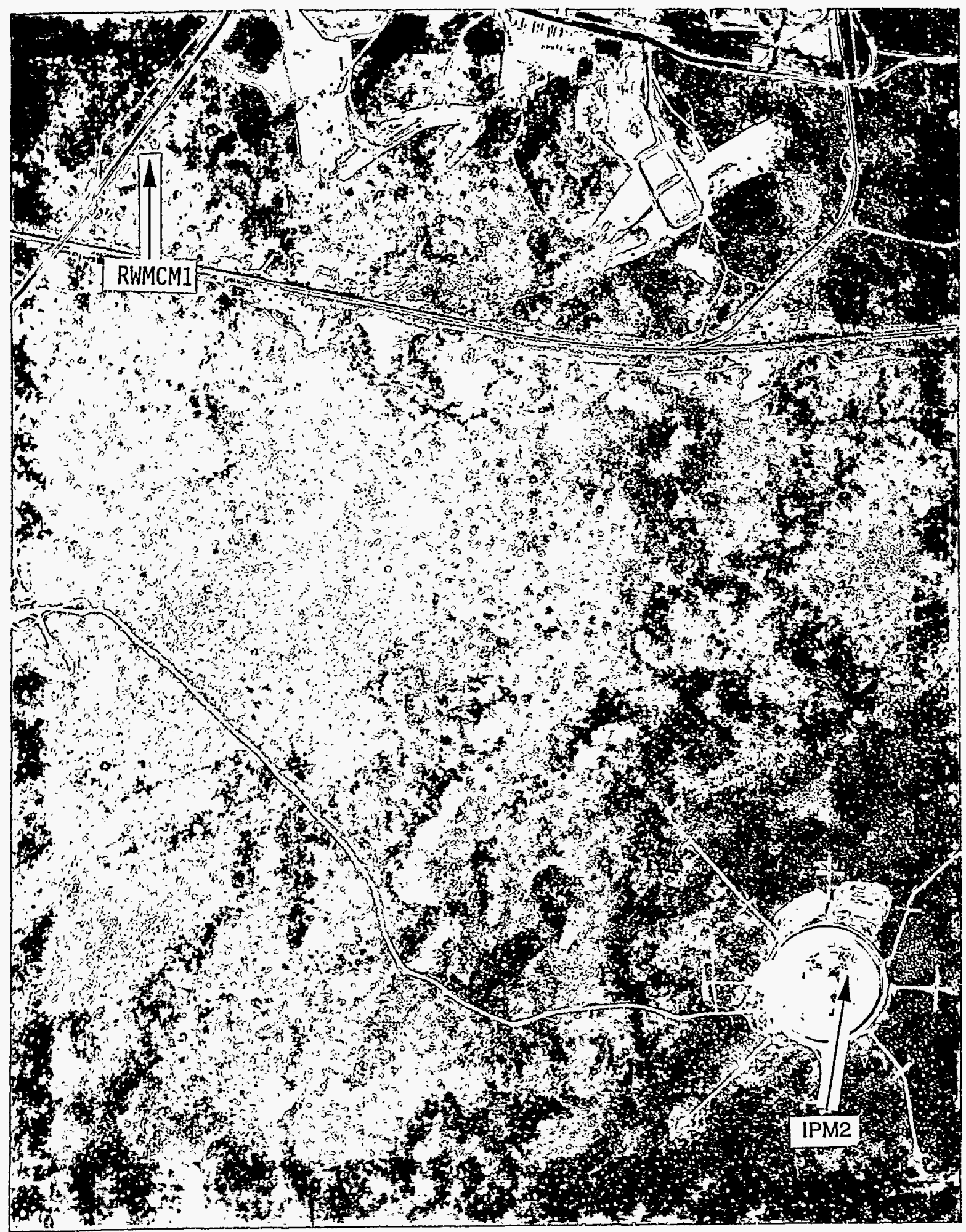

Plate 15 Aerial photograph showing the Tocation of RWMCM1 and IPM2. (Scale 1:10,000) 
The soils on the upslope end of the mound $(1120 \mathrm{~cm}$ profile) are separated from the mound interior by a distinct basalt rock line (rock line 1 on Plate 16) dipping approximately thirty degrees toward the mound. The boulders comprising the rock line are up to $40 \mathrm{~cm}$ in diameter, subangular, and completely engulfed in calcium carbonate. These boulders represent a paleosurface buried by subsequent loess deposition. Two soils formed in loess under the buried rock line. The upper part of the profile consists of an $\mathrm{A}, \mathrm{AB}, \mathrm{Bk} 1$ and $\mathrm{Bk} 2$ sequence similar to the downslope intermound soil (100 cm profile), although thinner. These horizons are of uniform thickness and appear to follow the general trend of the present slope. Bioturbation has disturbed the soils, and a large krotovina has obliterated the contact between the $\mathrm{Bk} 2$ and underlying buried soil.

The buried soil below the Bk2 consists of two horizons, Bkqmb and Bkqb. These horizons have a platy structure with very thin red crusts on ped faces. The Bkqb developed in a basalt rubble zone with clasts up to $\approx 10 \mathrm{~cm}$ diameter (rock line 2 on Plate 16). Both buried soil horizons and the basalt rubble dip at $\approx 10$ degrees. Older soil horizons overlying the Bkqmb are missing, possibly stripped by slopewash processes. The basalts forming the overlying rock line may have been deposited on this eroded soil surface.

Near the center of the trench (515 m), the upper soil horizons ( $\mathrm{A}, \mathrm{Bw}, \mathrm{Bk} 1$ ) are strongly mixed by bioturbation. The upper contact of the $\mathrm{Bk} 1$ is irregular, and peds of the $\mathrm{Bk} 1$ are easily recognized within the mixed surface sediment. The remainder of the horizon sequence, Bk1 (lower part), Bk2, Bk3, and Btk horizons, are undisturbed. The undisturbed Bk units are distinctly light-colored on Plate 17, and distinguishable from each other by differences in soil structure, color and dry consistence. They are riddled with krotovina $3-7 \mathrm{~cm}$ in diameter, which are more numerous toward the center of the trench. Soil textures are primarily silt loams, with increasing small gravel content in the $\mathrm{Bk} 2(5-10 \%)$ and $\mathrm{Bk} 3(30 \%)$. The top of the Btk unit was exposed in a hand-dug pit at the bottom of the trench. The contact between the Bk3 and Btk units was destroyed by a large, active mammal burrow.

A position representative of the intermound soil at the left (downslope) side of the trench (100 cm profile) exposes an undisturbed $\mathrm{A}, \mathrm{AB}, \mathrm{Bk} 1, \mathrm{Bk} 2$, and $\mathrm{BC}$ sequence. Silt loam textures dominate the profile, except at the base, where the $\mathrm{BC}$ is a loam. The intermound soil has only two Bk units as opposed to three in the mound soil. The lowest horizon, BC, exhibits only slight pedogenic alteration. This intermound position, close to the base of the mound and at the toe of a slope, has been buried slightly by slope processes moving loose, bioturbated soil downhill.

Soil horizons from the center of the mound upslope to the upper rock line (rock line 1) have been thoroughly bioturbated. The contact between undisturbed soil and bioturbated soil is smooth and abrupt (Plate 18). A large remnant of $\mathrm{Bk} 2$ is in place within the mixed soil. This remnant indicates disturbance by burrowing mammals and not by an erosional event. Many small $(1-2 \mathrm{~cm})$ peds from the Bk units are easily identified within the bioturbated soil in the center of the trench. Zones within the bioturbated soil are harder and contain increased calcium carbonate indicating development of a very weak soil. Small mammal bones are found throughout.

Interpretation. An eroded paleosurface covered with basalt boulders was buried by the loess, significantly smoothing the landscape. Soil moisture held in the fine-grained sediments was 
sufficient to form ice lenses during periods of intense seasonal freezing. Growth of ice lenses led to heaving of sediment and (possibly) frost jacking of basalts off the paleosurface. Pedogenesis occurred after the period of frost heaving creating a soil which is continuous across the mound/intermound boundaries, and not disrupted by cryogenic structures or fabrics. Intense mammal activity over long periods largely destroyed the soil structure in the interior of the mound.

\section{IPM2}

IPM2 is located $1 \mathrm{~km}$ south of RWMCM1 in a similar environment (Plate 15 and Figure 10). The mound/intermound boundaries are indistinct, and the height is $<0.5 \mathrm{~m}$, but the mound is easily identified by abundant annual mustard which is sparse in the intermound area. The mound is near the base of a gradual ( $<5 \%)$ slope. There are no basalt outcrops nearby. IPM2 was trenched as part of a separate project during the summer of 1993, and due to time constraints logging was not completed to the level of detail as other trenches. However, the stratigraphy and soils in this trench are of interest to this study. The trench was oriented downslope with a southeast facing vertical exposure. The trench log is shown in Figure 12 (foldout in envelope) and a long view of the trench is shown in Plate 19.

The soil in IPM2 formed in loess and slopewash sediments overlying a fractured, but solid basalt floor. The downslope, intermound soil is represented by the profile at $1300 \mathrm{~cm}$ (Plate 20). It is characterized by an $\mathrm{A}, \mathrm{AB}, \mathrm{Bk} 1, \mathrm{Bk} 2,2 \mathrm{Bk} 1 \mathrm{~b}, 2 \mathrm{Bk} 2 \mathrm{~b}$ and $2 \mathrm{Bk} 3 \mathrm{~b}$ horizon sequence. The $\mathrm{A}$ horizon has a loamy texture, moderate fine to medium granular structure, and a vesicular pore structure. The A horizon is discontinuous due to deposition of fresh spoils by burrowing mammals. The $A B$ is a silt loam, with moderate development of a medium to coarse subangular blocky structure. The Bk1 is a silt loam, with moderate development of a fine to medium subangular blocky structure. The $\mathrm{Bk} 2$ has even more calcium carbonate relative to the $\mathrm{Bk} 1$ and strongly developed medium to coarse subangular blocky structure. The buried soil, $2 \mathrm{Bk} 1 \mathrm{~b}, 2 \mathrm{Bk} 2 \mathrm{~b}$, $2 \mathrm{Bk} 3 \mathrm{~b}$ has a very fine, sandy loam texture with abundant basalt sand. The structure is generally massive, parting to a moderate fine to medium angular blocky structure. The peds are difficult to break and disaggregate for field texturing. With addition of water and continued working, the calcium carbonate breaks down, and the texture becomes heavier. The $2 \mathrm{Bk} 2 \mathrm{~b}$ and $2 \mathrm{Bk} 3 \mathrm{~b}$ contain many basalt boulders $(15-40 \mathrm{~cm}$ diameter).

The stratigraphy and soil development is continuous across the entire length of the trench, except for a zone of complete mixing by bioturbation. Many remnants of the lowermost soil horizons are in place within the bioturbated zone (Plate 21). Many small mammal bones and scat were discovered in the mixed sediments. The mound surface above the mixed section is subtly lower than the surface outside the mixed zone, possibly due to settling of disturbed soils. The floor in IPM2 is a massive, solid basalt, with the exception of a segment roughly coincident with the bioturbated zone. In this section, the floor is of fractured basalt boulders (20-45 cm diameter) some of which are stacked vertically in the overlying soil. These boulders are separated by, and therefore supported by fine-grained sediment. Additionally, basalt boulders (up to $45 \mathrm{~cm}$ diameter) found in the sediment above the floor were oriented with their broad (most stable) sides perpendicular to the basalt floor (Plate 22). These rotated and stacked boulders are interpreted as frost heaves from the basalt floor. 


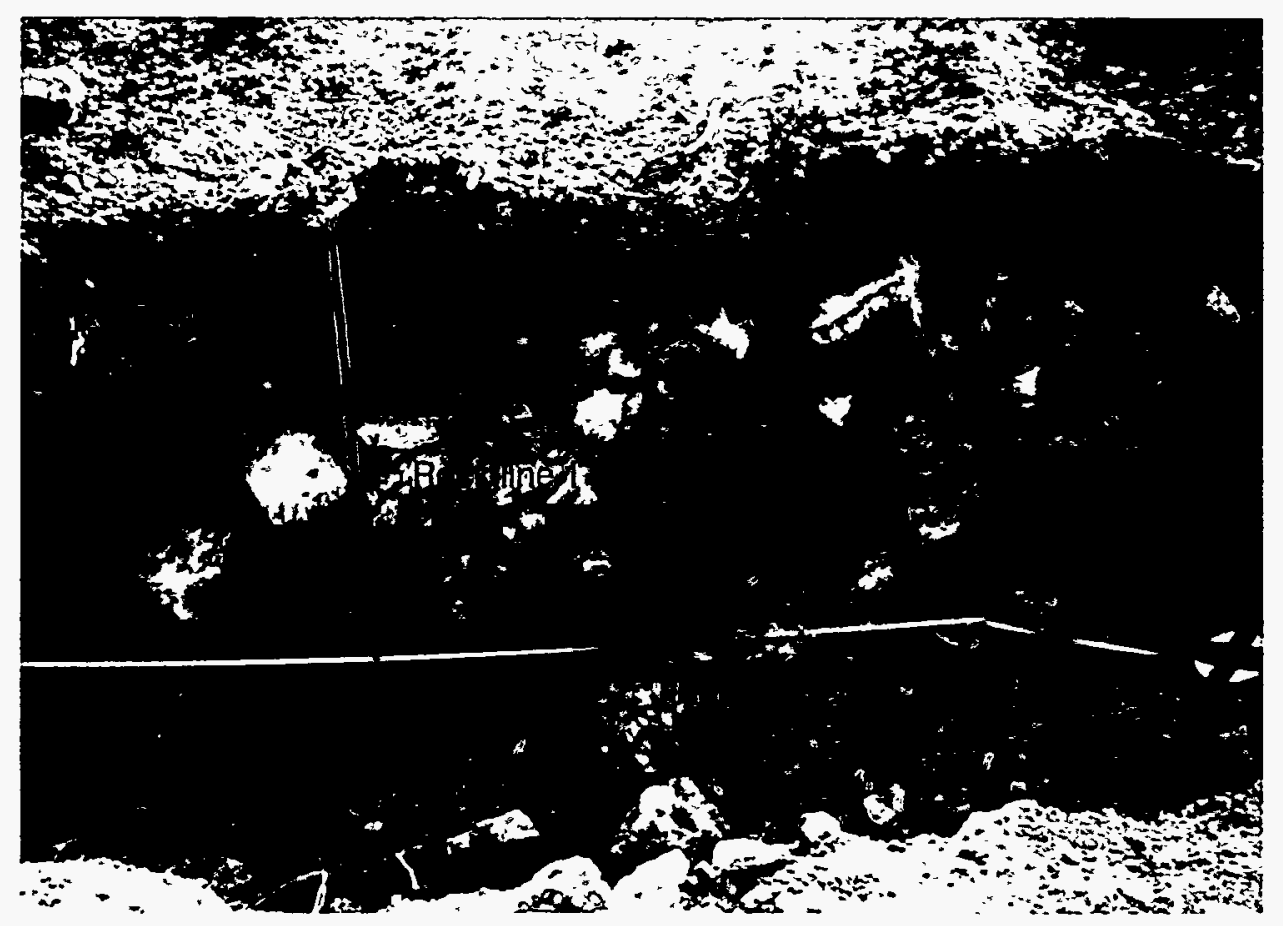

Plate 16 Photo showing the buried rock lines and soils in RWMCM1.

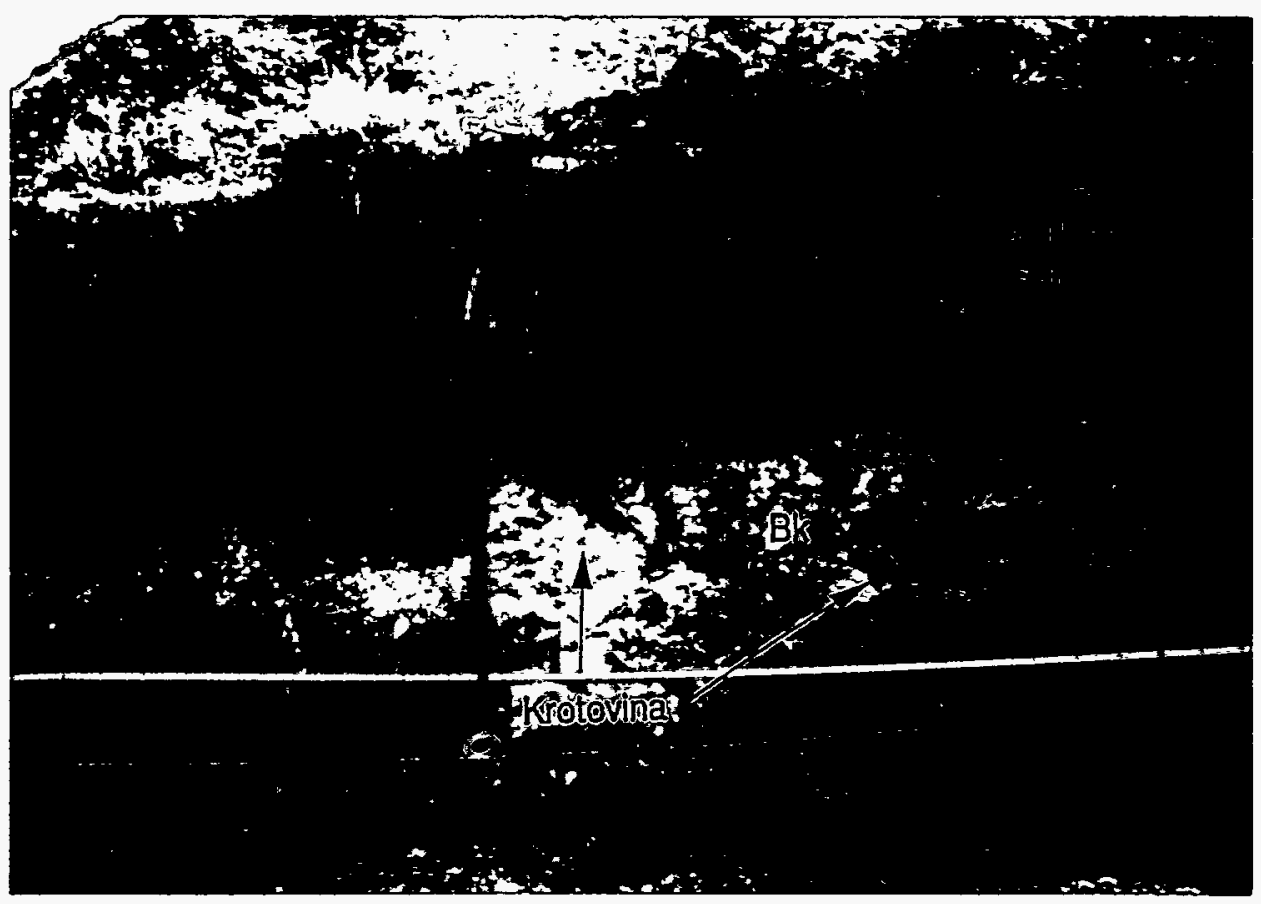

Plate 17 Soil profile near the left-center section of RWMCM1. 


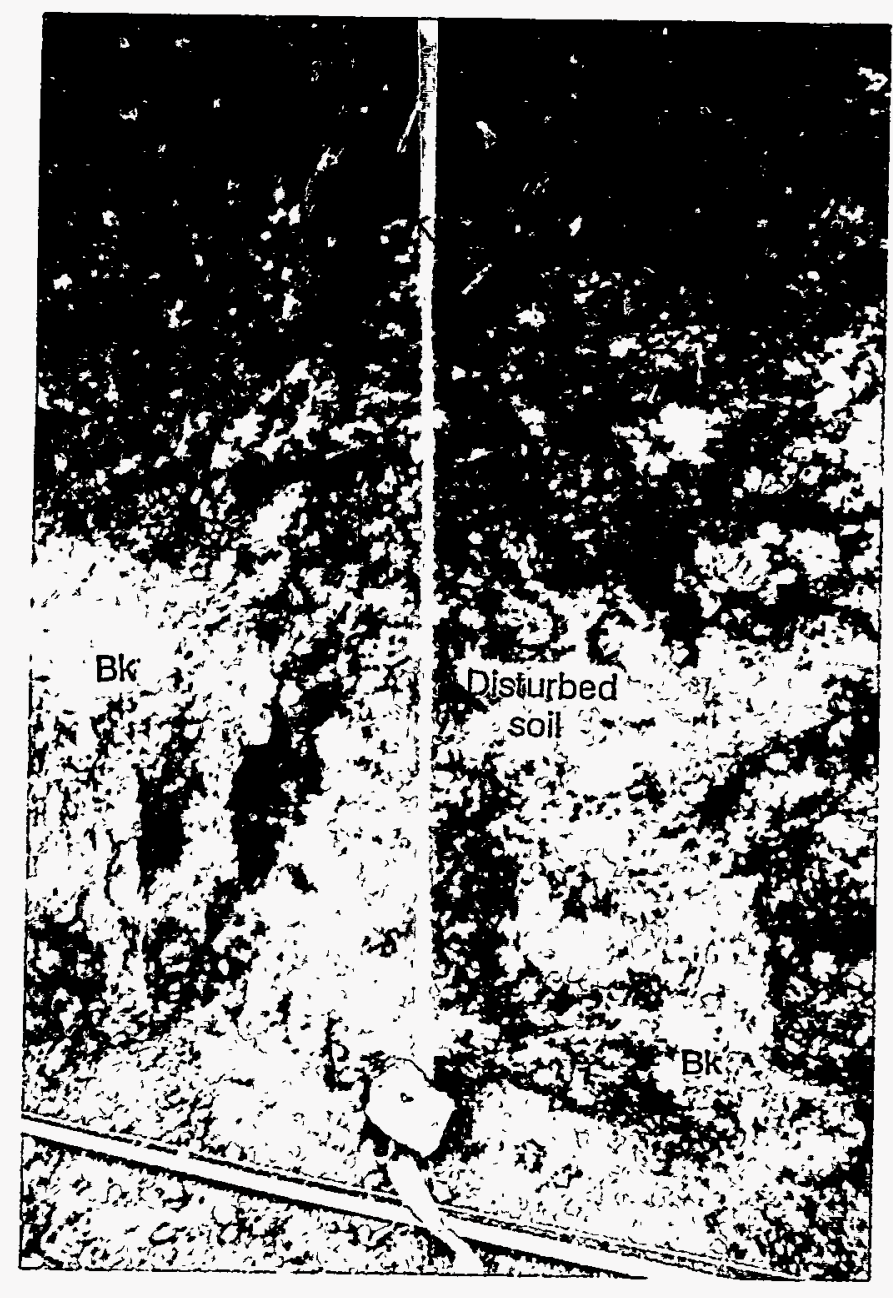

Plate 18 Photograph of the disturbed soil near the center of RWMCMI. 


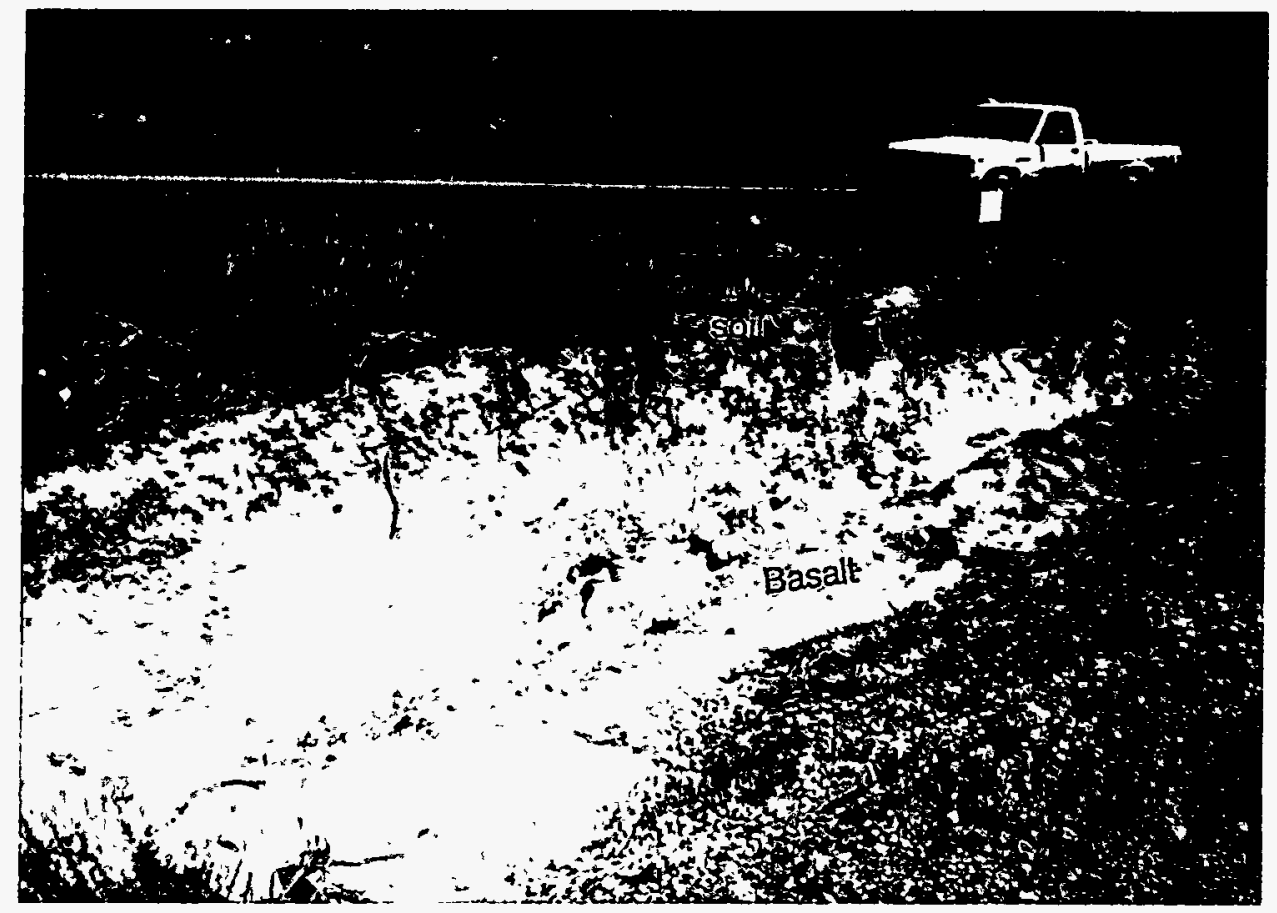

Plate 19 Photograph showing the entire 1ength of IPM2.

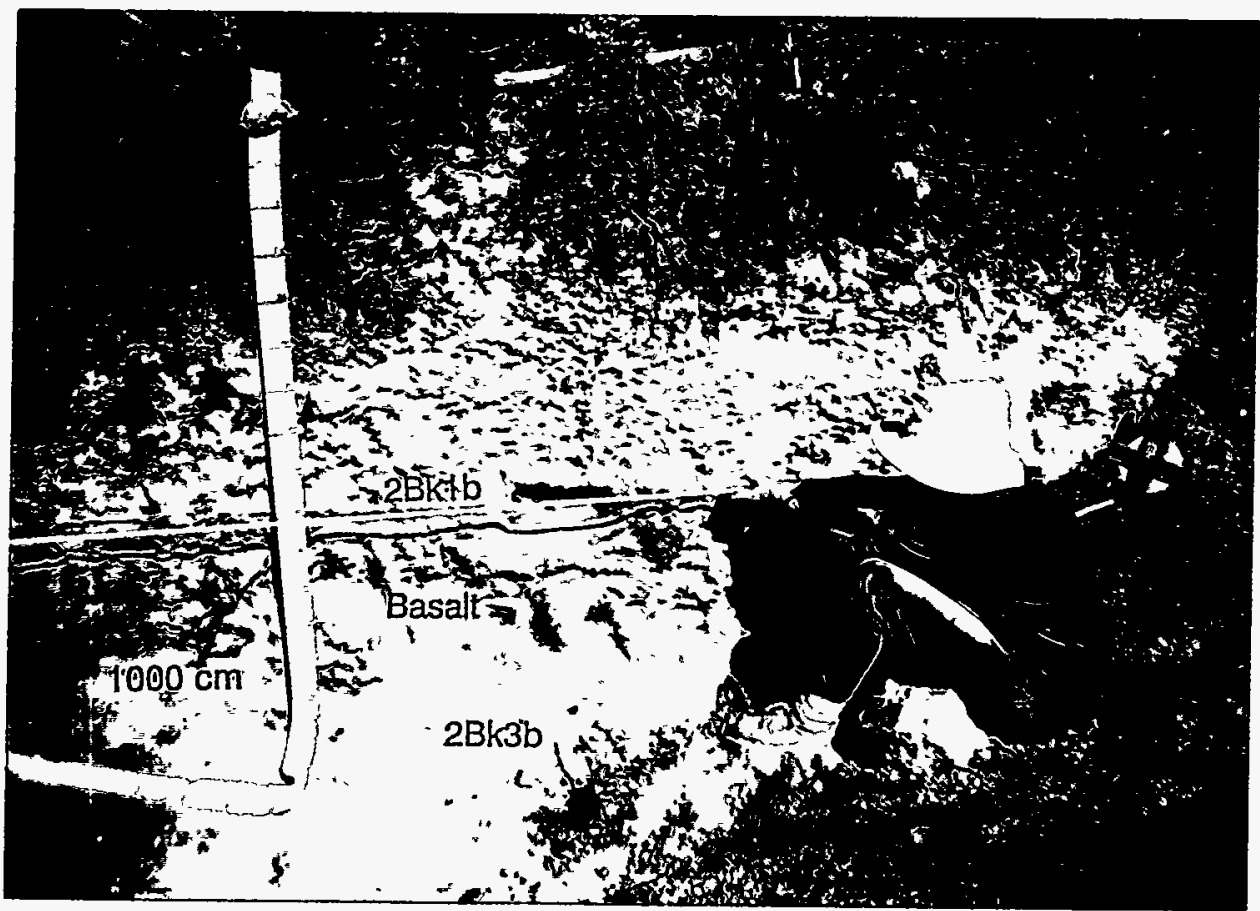

Plate 20 Intermound soil at right end of IPM2. 


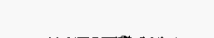

- 


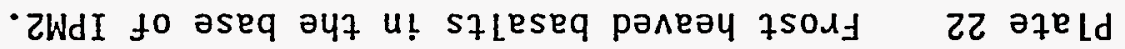

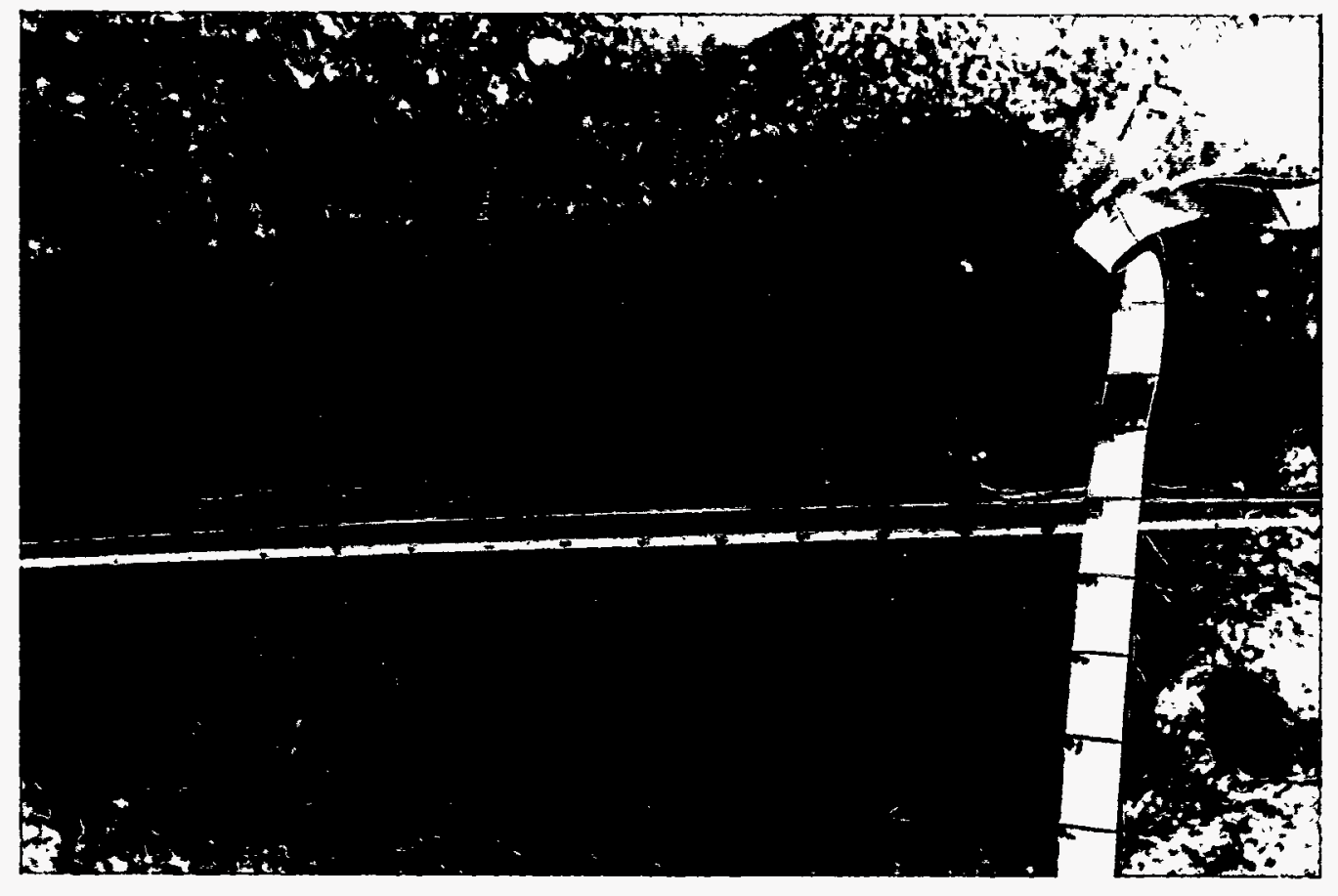

- ZWdI u! әUoz paqunzs!p [eлquәJ IZ әqeld

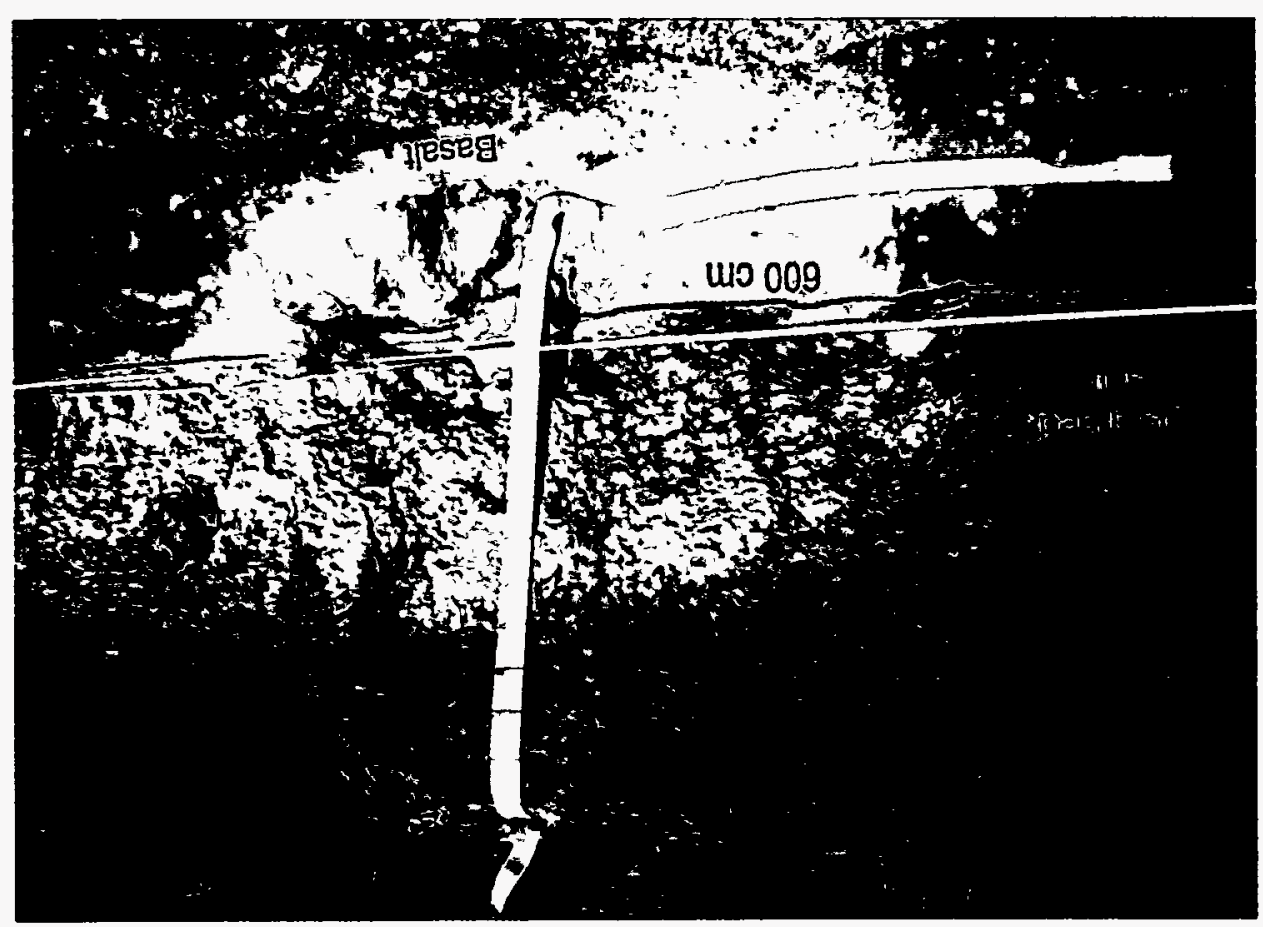


Interpretation. The basalt surface was buried by sandy loam containing abundant basalt sand of local origin. Big Southern Butte was a source of surface runoff transporting sediment to basins in this area (Dechert et al., 1994), and may have contributed sediment to this location as well. Pedogenic processes developed a thick zone of carbonate accumulation (the $3 \mathrm{BK} 1 \mathrm{~b}, 3 \mathrm{Bk} 2 \mathrm{~b}$, and $3 \mathrm{Bk} 3 \mathrm{~b}$ horizons).

The surficial horizons of this buried soil were either eroded off or engulfed by later translocation of calcium carbonate from overlying sediment. The paleosurface was subsequently buried by loess. Heaving was caused by the growth of ice lenses in the fine-grained loess. It is not known why the mound developed at this particular location. It is possible that environments with uniformly thick sediments will develop mounds wherever ice lenses are nucleated. The thick package of sediment provides sufficient moisture migration to the freezing front, and perhaps mounds in these environments form at regularly spaced intervals. This aspect was not part of this investigation, but would be important for follow-up work. The fractured basalt surface was disturbed by the freezing process, such that boulders were rotated and heaved upward into the overlying sediment. Soil horizons in the loess follow the contour of the present land surface (including the mound shape), and are continuous across the mound/intermound boundary, indicating that formation of the younger soil occurred after heaving of the sediment. Bioturbation followed pedogenesis, largely mixing the soil horizons in a large section in the interior of the mound.

\section{RGFM1}

RGFM1 is located south of Ryegrass flats on the north flank of the Axial Volcanic Zone (Figure 13 and Plate 23). The area is within the el2 loess as mapped by Scott (1982), and described in the introduction to loess-over-basalt trenches. Sediment thickness (as mapped) in the location of the trench ranges from 0.5 to $1.5 \mathrm{~m}$. The trench is on the southwest-facing slope of a large bowl. Bedrock outcrops on the east, northwest, and south of the bowl. The trench is within an old wildfire burn which was revegetated with crested wheatgrass in the early 1950's. Mounds in this area are only a few tens of centimeters high, but are readily identified by their characteristic vegetation. Mounds are vegetated almost exclusively by halogeton, and intermounds with crested wheatgrass and sparse occurrences of sagebrush, winterfat, and milkvetch (Plate 24). Numerous large (up to $60 \mathrm{~cm}$ diameter) basalt boulders occupying intermound surfaces have been overturned, and display thick caliche rinds on their present upper surfaces. Lichen colonies have grown on the caliche-covered, exposed sides. A plausible, but unconfirmed hypothesis for the present state of these boulders, is mechanical discing done prior to reseeding. Some mounds have basalt cobbles on their surfaces, but not as concentrated as on the intermounds.

The RGFM1 trench was oriented N-S with the downslope end at the south, and the vertical wall facing east. The trench profile is shown in Figure 14 (foldout in pocket). The stratigraphy and soils in this trench are complicated by numerous soil structures and bioturbated zones. The floor of the trench is formed by basalt bedrock which dips in the upslope direction at about three degrees. The basalt was exposed by the trenching between 0 and $600 \mathrm{~cm}$, but was not exposed upslope because it extended below the allowed trenching depth. Soil textures, bedding, and the presence of basalt sand throughout indicate the deeper sediments were deposited by slopewash processes, at once reworking loess and incorporating sand from weathering basalt outcrops. The upper sediments are largely loess. 
The downslope intermound soil $(0-600 \mathrm{~cm})$ is characterized by an A,Bw, Btkb, 2Btk1b, and $2 \mathrm{Btk} 2 \mathrm{~b}$ profile sequence (Plate 25 ). The upslope intermound soil is characterized by an $\mathrm{A}, \mathrm{Bw}$, $2 \mathrm{Bk} 1,3 \mathrm{Bk} 1 \mathrm{~b}, 3 \mathrm{Bk} 2 \mathrm{~b}$, and $3 \mathrm{Bk} 3 \mathrm{~b}$ profile (Plate 26 ). The surface soils are weakly developed in loess overlying the buried soil. Plant pedestals (up to $9 \mathrm{~cm}$ ) and the high position of buried soil horizons indicate that erosional processes have removed a significant thickness of younger soil. Irregular erosion of the surface soil and position on the slope may account for differences in development of the surface soil noted between the upslope and downslope intermound positions.

The buried soil formed in multiple layers of slopewash sediment which differ in thickness and depositional structure. The $3 \mathrm{Bk} 2 \mathrm{~b}$ horizon is the thickest slopewash unit which can be traced laterally across the trench. These sediments dip downslope from the right end of the trench. On the left side of the trench (downslope) the surface of the deposit dips into the mound center, but this is probably an artifact of later disturbance. The slopewash sediments get progressively finergrained in the downslope direction. The clays in the downslope intermound paleosol are attributed to primary deposition and not illuviation. The buried soil effervesces strongly and has high value colors.

The intermound areas are complicated by numerous structures: old krotovina, frost involutions, wedges, and heaved basalt cobbles. The krotovina are round, up to $20 \mathrm{~cm}$ in diameter (i.e., at the contact between the $2 \mathrm{Btk} 1 \mathrm{~b}$ and $2 \mathrm{Btk} 2 \mathrm{~b}$ at $180 \mathrm{~cm}$ ), and have accumulated calcium carbonate. They are labeled as $\mathrm{K} 2$ on the $\log$ to indicate very old mammal activity.

The involutions occur in the trench segment from $0-85 \mathrm{~cm}$ (Plate 25). Soils are contorted with higher value color patches surrounding remnants of the Btkb and $2 \mathrm{Btkb}$ horizons. This distortion gives an overall mottled appearance to the soil. Although it is possible the features were caused by mammal burrowing, typical evidence of bioturbation such as organic matter, bones, loose soil consistence, and abrupt boundaries are not present. Involutions are caused by freezing and thawing of the soil, either seasonally or associated with permafrost. The deformation is caused by volume changes of the soil during freezing of pore water.

Several large basalt rocks $(10 \times 15 \mathrm{~cm})$ are found in the Btkb horizon in the downslope intermound area. They are oriented flat-side down, with caliche coats on the bottom. A similar size rock sits on the intermound surface close to the end of the trench. Two large basalt boulders protrude upward into the soil from the bedrock floor at $320 \mathrm{~cm}$, and several small rocks (up to $10 \mathrm{~cm}$ ) are supported within the soil matrix of the 2Btk2 horizon. Although they may be relics of the paleosurface, it is also possible that they have been heaved into their present position by freeze/thaw processes.

Wedge structures occur in several locations $(225-255 \mathrm{~cm}, 350-360 \mathrm{~cm}, 470-475 \mathrm{~cm}$, and 1910 1920), extending from the top of the Btkb to the floor of the trench (Plate 27). The wedges are wide at the top, but narrow at the bottom to as little as $1 \mathrm{~cm}$. The 1-cm wide wedge point of one such structure was traced across the floor to the opposite trench wall indicating the wedge was at least a meter long. The wedges are filled with silt loam (25\% clay), and have a distinctly lower (darker) color value. These wedges are very similar to those described by Black (1976) as seasonal frost cracks developed where snow cover is shallow and sharp cold spells occur. They may also be attributed to drying contraction or other processes. 


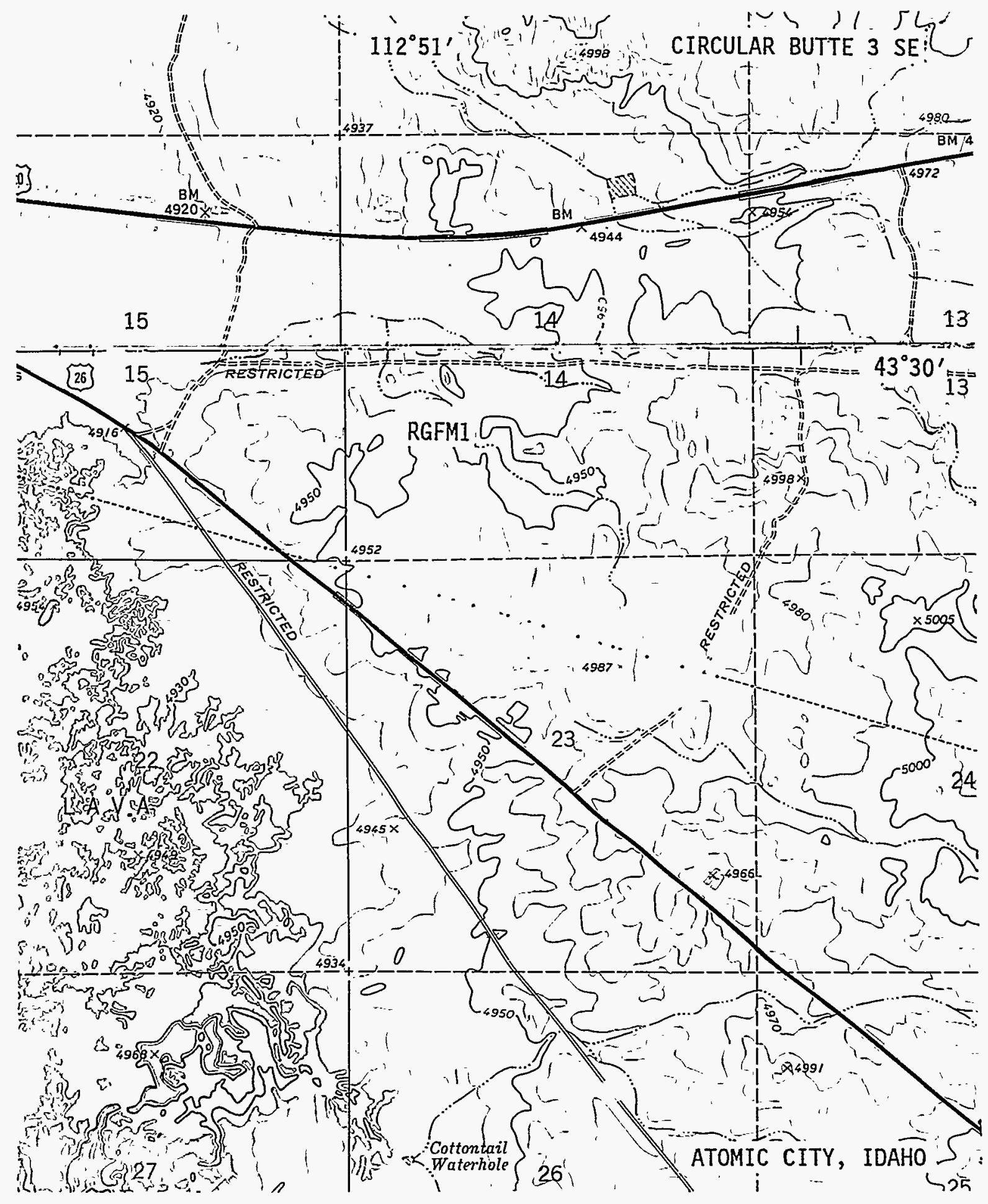

Figure 13 USGS 7.5 minute topographic map showing the location of RGFM1. 


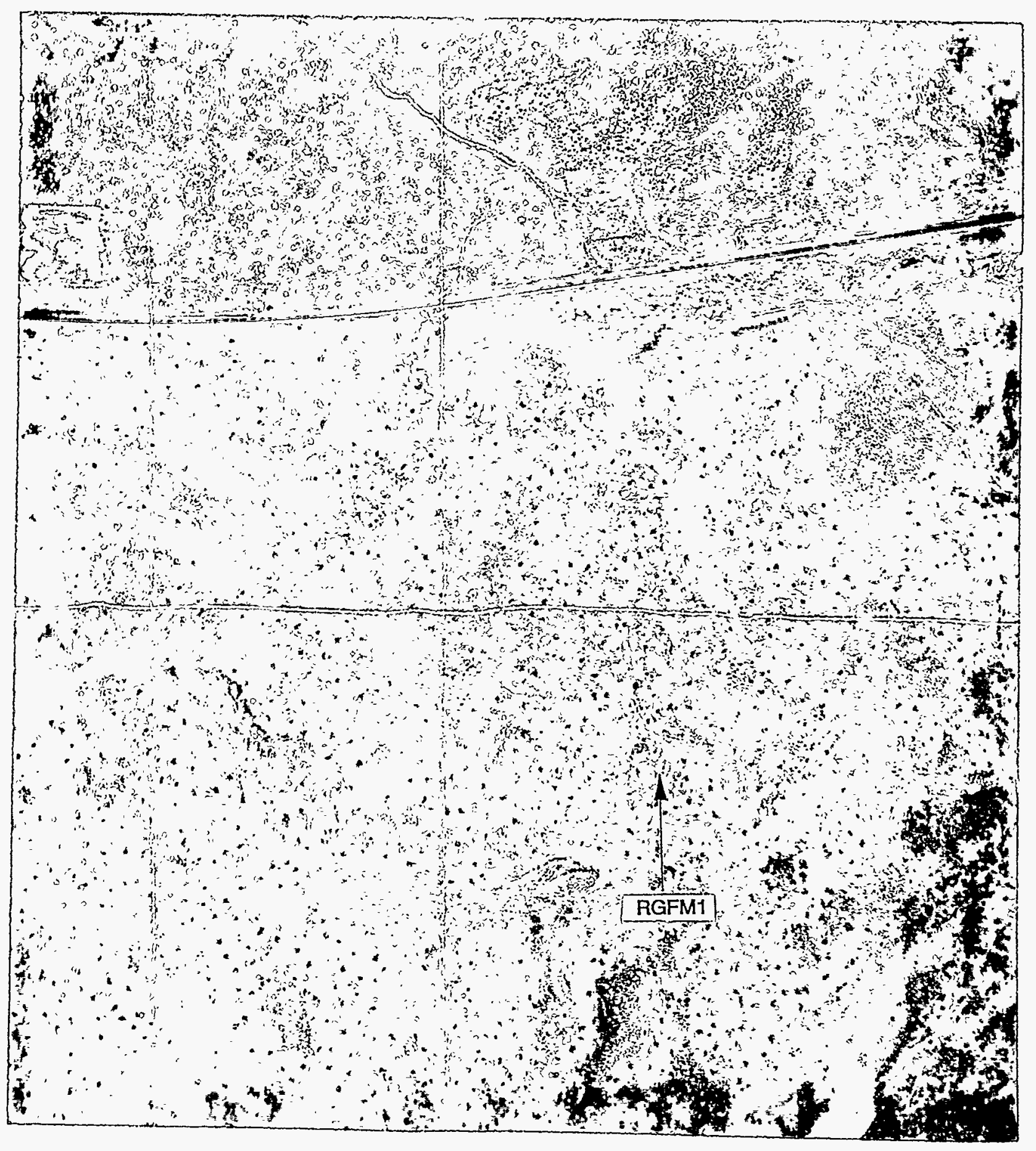

Plate 23 Air photo showing the location of RGFMI $(1: 10,000$ scale). 


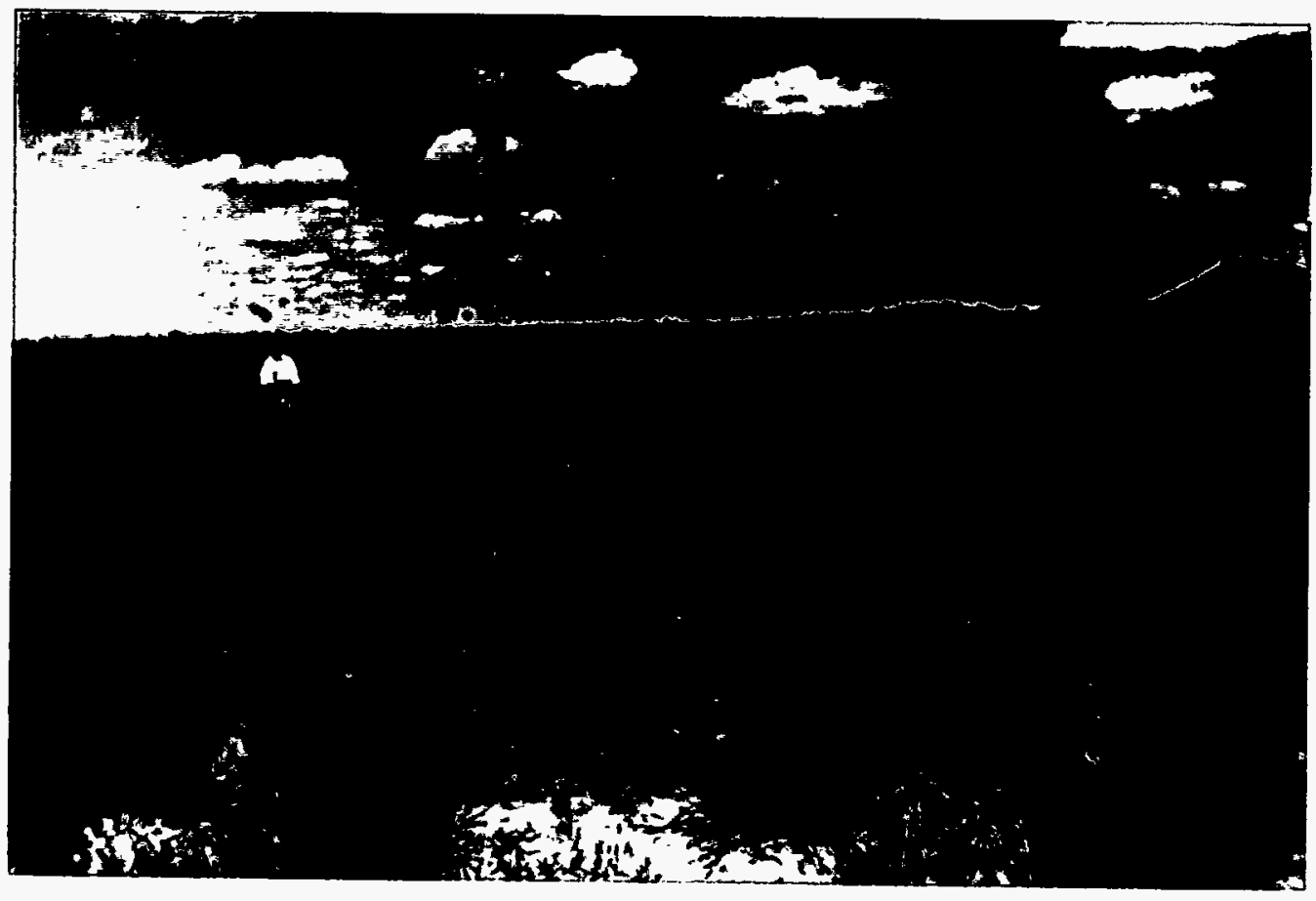

P1ate 24 Photograph showing the surface of RGFM1.

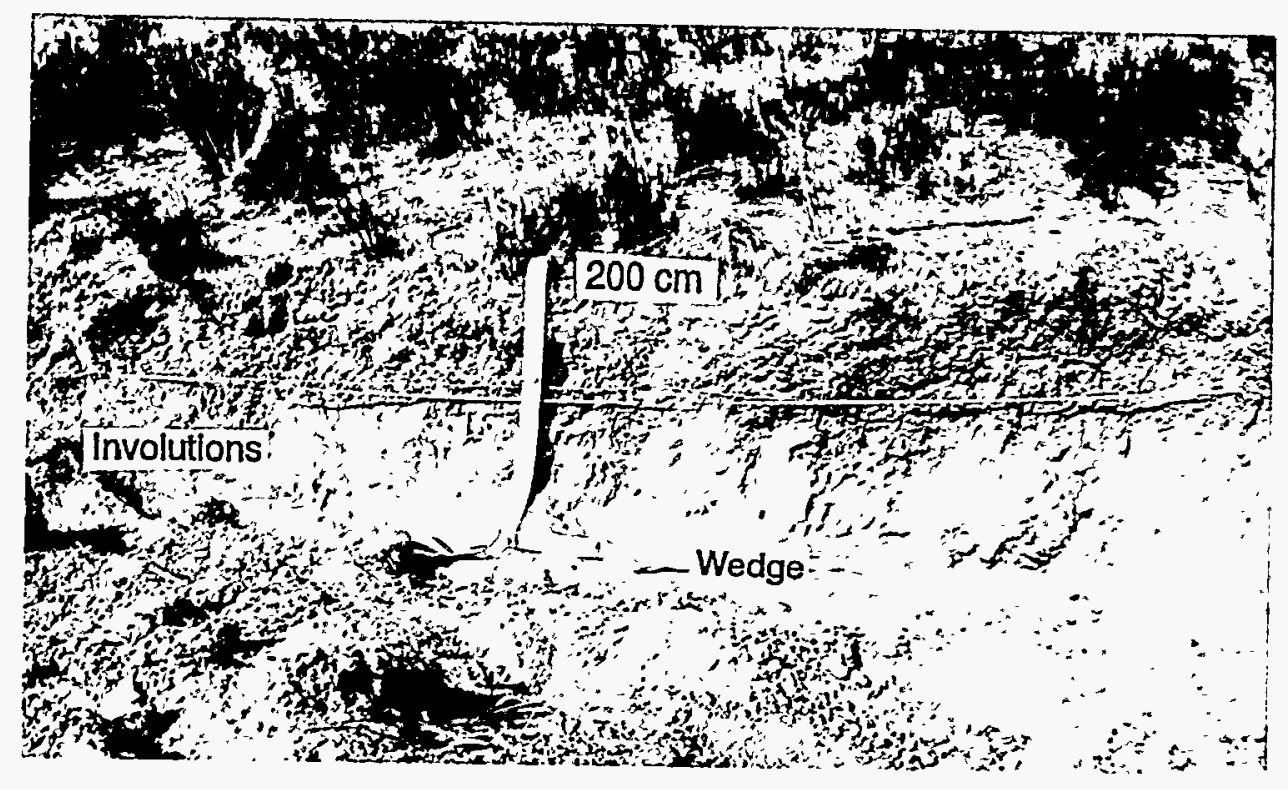

Plate 25 Photograph showing the downslope intermound soil at the left of RGFMI. 


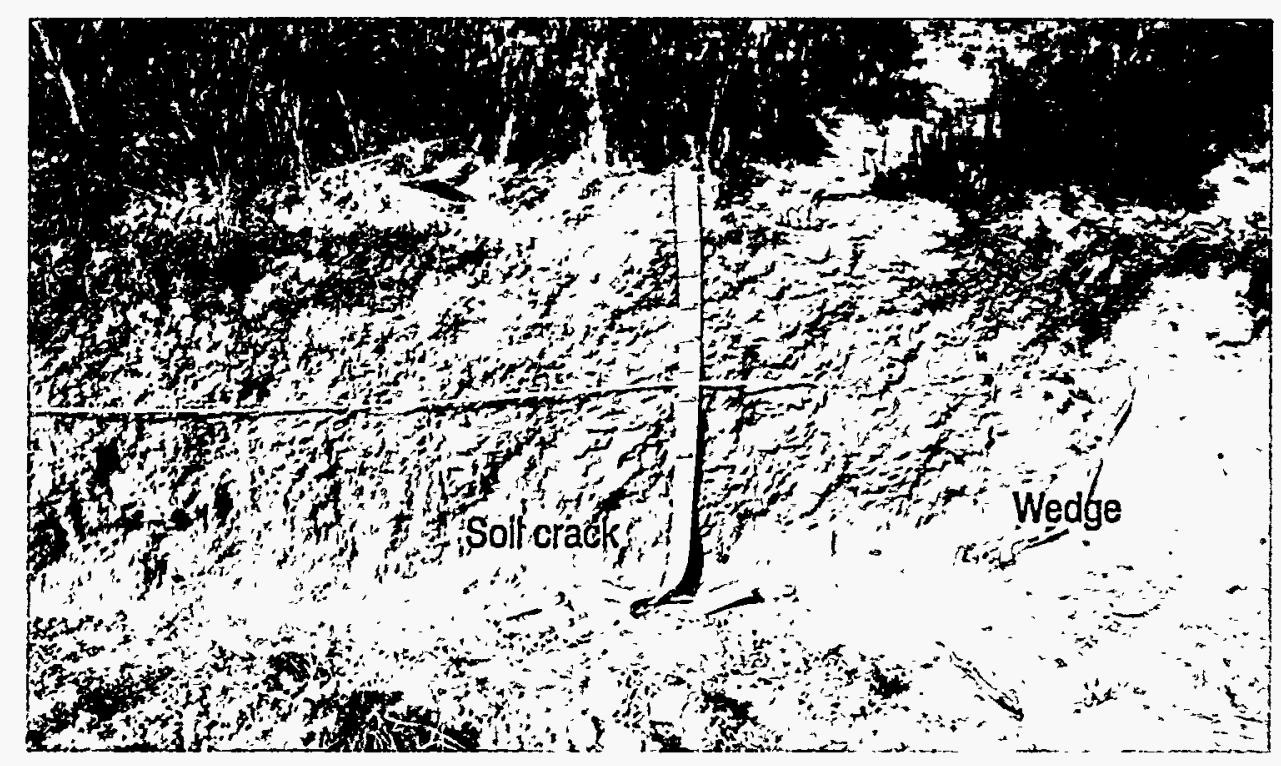

Plate 26 Photograph showing the upslope intermound soil in RGFMI. 
Several vertical or near vertical fractures formed in the upslope intermound paleosol (Plate 28). The fractures have very fine coatings of darker colored dust which makes them clearly visible.

No fabrics or rotated peds or rocks were associated with these fractures as in the ones observed in 8MFM2. Although not readily apparent, they form the faces of a large prismatic structure overprinting the structure in individual soil horizons. These cracks are very similar to those resulting from freezing and thawing of soils in a test chamber (Chamberlin and Gow, 1979). Between 400 and $1500 \mathrm{~cm}$, the trench soils are significantly disrupted by numerous krotovina ranging from small burrows to large (up to $1 \mathrm{~m}$ wide) mixed soil zones (Plate 29). Numerous bones, scat, and organic debris were found in the krotovina. The soil profiles exist mainly as remnants between disturbed zones. A weak surface soil has formed in completely bioturbated sediments. The A horizon typically has a very coarse prismatic structure underlain by a massive or weakly subangular blocky zone. Clasts of the underlying soil horizons are recognized within the mixed sediment.

Interpretation. Interpretation of the stratigraphic, pedogenic, and mound-forming history of this trench is complicated by significant mammal disturbance. The buried soil apparently formed in a series of slopewash deposits over a basalt bedrock floor. Sediments with varying amounts of clay, silt, and basalt sands were likely transported and deposited during multiple erosional episodes. The paleosol was buried by loess in which the Holocene age soil formed. Ongoing slopewash erosion has thinned the surface soil, causing pedogenic alteration of the buried soil horizons, especially with respect to additions of calcium carbonate.

Active and extensive mammal activity, and continued erosion of the surface soils complicate the interpretation with respect to mound development. Given the fact that the present sediments forming the actual mounded surface are largely mixed, bioturbated soil horizons from below, it is apparent that the activities of burrowing mammals have resulted in the presently elevated surface of the mound. However, the subsurface characteristics that are common to other mounds in this study, (i.e., basalt/silt capillary barrier, $1.5 \mathrm{~m}$ of fine-grained sediment thickness) and the presence of frost-related structures in the buried soil support the conclusion that the mound was originally formed by freezing processes. The present surface of the mound resulted from postmound modification by slopewash processes and mammal activities. 


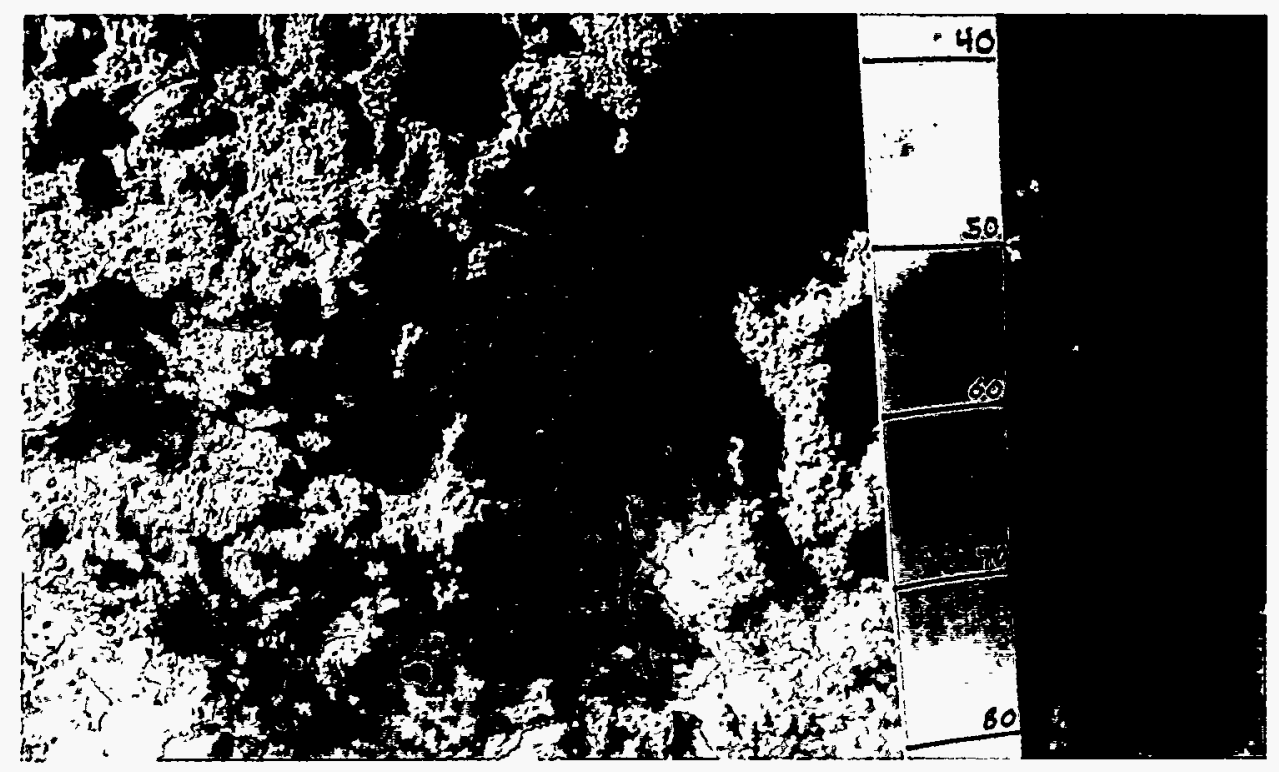

Plate 27 Photograph of a wedge in the intermound soil of RGFM1 remnant soils.

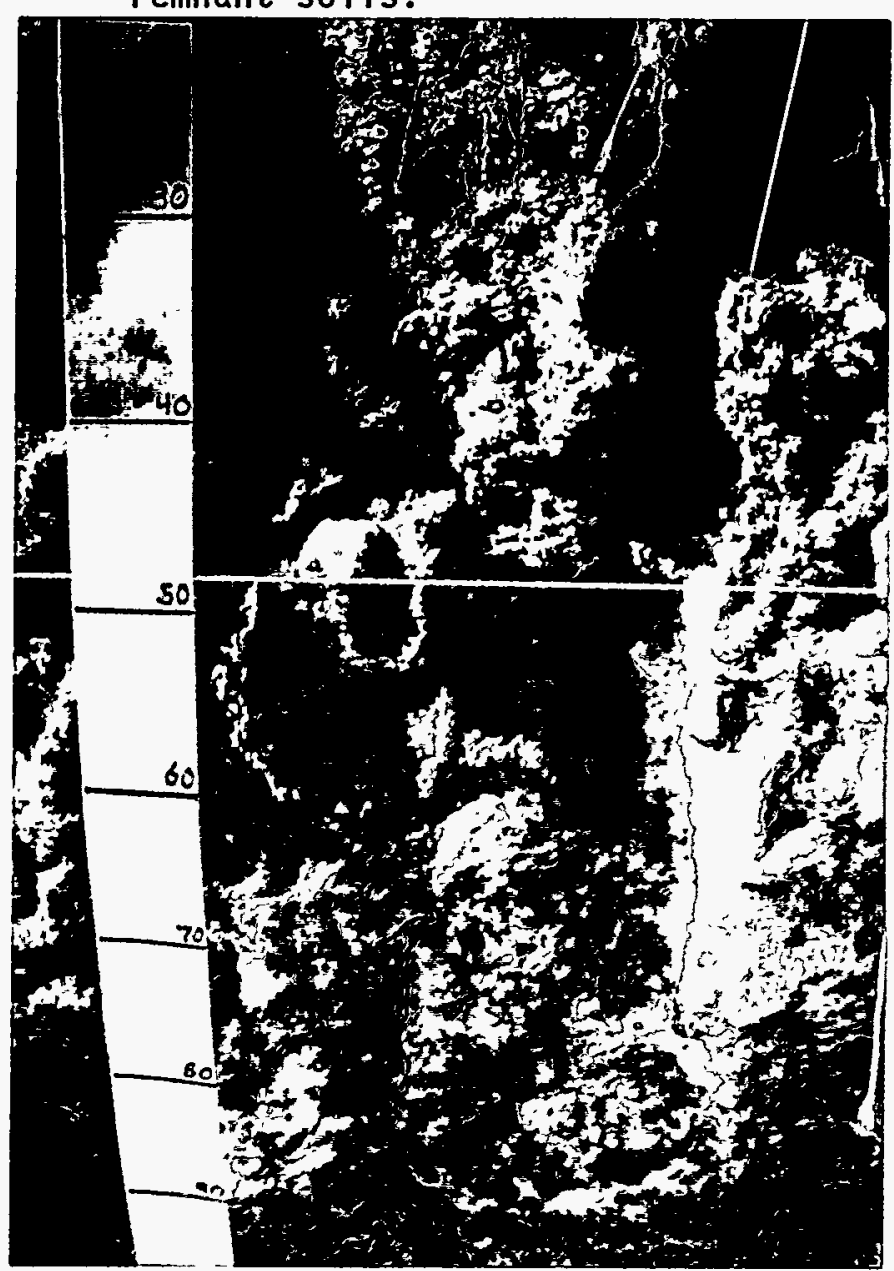

Plate 28 Photograph showing soil fractures in the intermound soil of RGFMI. 


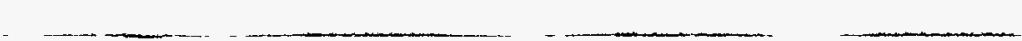




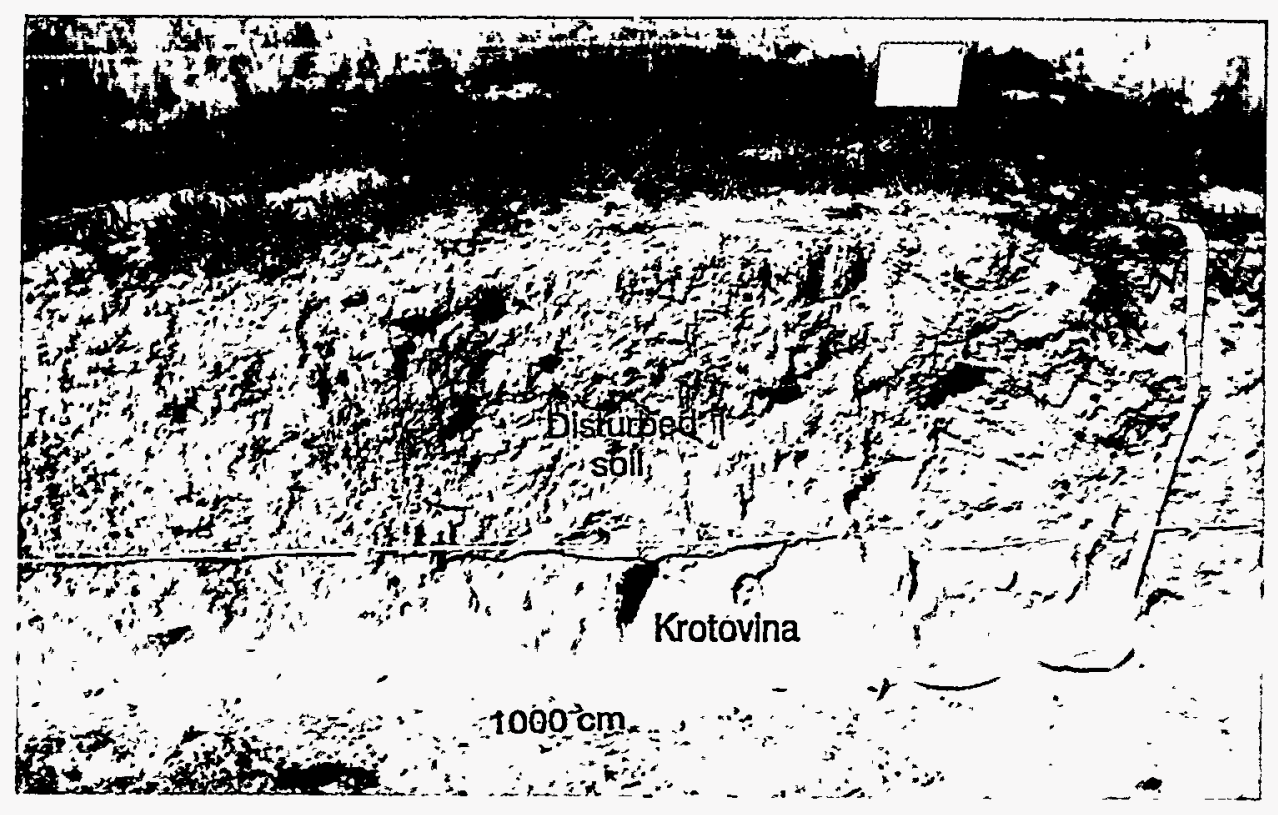

P1ate 29 Photograph showing the central disturbed zone in RGFM1. 


\section{DISCUSSION}

The origin of the mounds can be determined by examining the regional climate history, surface distribution of mounds, and mound stratigraphy, pedogenesis, structural features, and biological features. Each trench revealed some features unique to that site, and some features common to most (or all) sites. The features of individual mounds may not, when taken alone, support a hypothesis for mound formation, however when the data for multiple sites are compared an understanding of the mound-forming process emerges. The following discussion compares and contrasts the data within the context of frost heaving as the primary process by which the mounds were formed.

\section{Regional Paleoclimate}

The mounds examined in this study formed within the confines of the ESRP. Although microclimate conditions at individual sites may have varied, it is assumed that the regional climate during the time of mound formation was consistent for all locations. Absolute temperatures on the ESRP during the Late Pleistocene and Holocene are uncertain; however, during the last glaciation, alpine glaciers formed in the ranges north of the ESRP and alpine permafrost developed in parts of Idaho (Dawson, 1992). Summer temperatures $18 \mathrm{ka}$ may have been $10^{\circ} \mathrm{C}$ lower than today, and $13 \mathrm{ka}$ temperatures may have been $3-4.5^{\circ} \mathrm{C}$ lower than today (Thompson et al., 1993). No specific evidence of permafrost has been identified on the ESRP, however the involutions, wedge structures, and soil cracks identified in RGFM1 are similar to those described by Black (1976) which are indicative of a climate with shallow snow cover and sharp cold spells. Additionally, ice wedge casts have been identified in soils at the Wasden cave site (Dort, 1968). Currently, the depth of ground freezing on the ESRP is between 46 and $137 \mathrm{~cm}$ (Washburn, 1980). This depth of freezing would increase as the freezing index increases, a condition likely to have occurred during the Late Pleistocene.

Temperatures after about 10,000 years ago were generally warmer and drier than those during the late Pleistocene, leading to the thermal maximum around 7,000 years ago. Temperatures cooled after the Altithermal, leading to advances of some alpine glaciers during the Neoglacial (Richmond, 1986).

\section{Mound Physiography}

Although no statistical analyses were completed on mound size and shape, the measurements of mounds used for trenching, and the numerous mounds observed over the course of several years of field work, indicate that variations in diameter, height, and shape are minimal. This is apparent on the aerial photos (Plates 1,8,15,23) although they are at a small scale. Differences in these parameters can often be explained by such factors as slope, intermound erosion, and biotic disturbances.

\section{Vegetation}

All mounded areas are similar in that there are distinct differences in the vegetation communities and growth patterns between the mound and intermound areas. Typically, the plants 
on the mounds are denser, taller, and may include more annual species. There is also a noticeable increase in dead plants (mostly sagebrush species) on the mounds. Although the plant communities vary from one site to the next, these vegetation differences help identify the field location of mounds, and are typically what make the mounds readily identifiable on aerial photos. It is highly likely that the observed vegetational differences between mounds and intermounds are due to the activity of fossorial rodents. Rodent activities can change parameters such as soil chemistry, structure, density, and water-holding capacity (Mielke, 1977; Huntley and Reichman, 1994). Populations of some plant species may be decreased due to foraging or sensitivity to disturbance, or conversely may be increased because they are avoided as forage, or benefit from disturbance (Huntley and Reichman, 1994). The simple explanation of mammal activity as the cause for vegetational differences should be further investigated because the subsurface bioturbated zones did not directly correlate with surficial vegetational differences. This occurred especially near mound/intermound boundaries outside the centralized zones of bioturbation. Although vegetation was not specifically addressed in this study, it could be possible that vegetation is responding to other mound-related factors.

\section{Mound Floors}

The floor or basement of the mounds is formed by a distinct change in stratigraphy, e.g., basalt bedrock, alluvial fan gravels, braided stream gravels, and buried soil surfaces. The mound floors are paleosurfaces buried by up to $1.5 \mathrm{~m}$ of fine-grained sediments. The paleosurfaces formed by sedimentary deposits were typically lower than their immediate surroundings (due to erosional processes), so that subsequent deposition resulted in greater thickness of fine-grained soil at future mound sites. Examples are the buried paleomeanders and erosional channels on the Big Lost River terraces and Eight-Mile Fan. Basalt bedrock basements (i.e., IPM2) do not reflect any specific shape, but apparently must be buried by a sufficient thickness of sediment before mounds are likely to form. There is evidence that basalt rocks and alluvial gravels were heaved off the basement into the overlying sediments, thus enhancing the concave shape observed in the trenches.

The basement stratigraphy is a critical element to the formation of earth mounds at these locations. Increased hydraulic conductivity in coarser grain sizes and basalts (relative to the overlying sediments) resulted in formation of a capillary barrier to the infiltration loss of soil moisture. This capillary barrier (coupled with the greater sediment thickness at mounded sites relative to nonmounded sites) probably influenced the amount of moisture available for migration to a freezing front during periods of intense cold.

\section{Stratigraphy}

Multiple sedimentation processes, i.e., flooding, eolian deposition, or slopewash, filled depressions in the paleosurfaces, thereby smoothing the overall terrain. Although various sedimentation processes were involved, the paleosurfaces were generally buried by up to $1.5 \mathrm{~m}$ of fine-grained sediments. Soil textures range from loamy sand to clayey silt, but are largely comprised of silt loams. Gravel content in the sediment ranges from zero to $\approx 20 \%$. These gravels are largely part of the primary sediment package, however increases in gravel content toward the center of some mounds (discussed in the descriptions) may be a response to frost 
heaving processes. The overturning of gravels in the bioturbated zones (as evidenced by orientation of caliche rinds) is probably the result of burrowing.

\section{Pedogenesis}

The interpretation of the relationship between pedogenesis and mound formation is key to determining the timing of mound formation. If pedogenesis of the surface soil preceded mound formation, the mounds must be very young because these surface soils are typical of others on the ESRP which required 10,000 - 15,000 years of weathering. Conversely, if pedogenesis postdated mound formation, the mounds must be Late Pleistocene or early Holocene age. Although the relationship between mound development and pedogenesis is not completely obvious, a careful consideration of evidence from all the trenches indicates that mounds formed in unweathered sediment overlying paleosols, so that the surface soil is younger than the mounds. Several lines of evidence support this conclusion.

First, the surface and buried soils are continuous across the intermound/mound boundaries. If the mounds were younger than the soil, some form of heaving disruption should be evident. In the surface soils, there is no evidence of frost related structures, fabrics, or segregations which would likely occur with the formation of ice lenses (even those only centimeters thick). It is important to note that stronger development of soil structures were observed in the mound (versus intermound) soils in the Bk horizon in $8 \mathrm{MFM} 2$, and that changes in color and stronger structure (mound versus intermound) were observed in IPM2. Soil structures reflect a variety of environmental conditions, but stronger structure is usually associated with increased clay content and not frost action. In the buried soils, the effects of frost heaving are recorded in frost heaved boulders and gravels (i.e., IPM2, BLRM2) and in the frost-related wedges, involutions, and cracks observed in RGFM1.

Secondly, the gravel content in surficial sediments of some mounds increases in the mound relative to the intermound. These inequant gravel clasts are oriented in all directions, but the caliche coats formed only on the bottom of the clasts. The increase in gravel content in the mound versus intermound reflects heaving of basement gravels, and the position of the caliche coats indicates their presence in the sediment prior to soil formation.

Thirdly, as will be discussed in the next section, weak soils have formed in the bioturbated sediments in those trenches where the existing soils were completely mixed (i.e, RGFM1, RWMCM1, 8MFM2). These weak soils probably do not require thousands of years to develop, but enough time has passed to allow leaching and redistribution of calcium carbonates and development of weak soil structure. This may have occurred during the wetter period of the Neoglacial, and may be continuing at present. Regardless, these incipient soils have formed after development of the mounds and after development of the Holocene soil. The timing of mound formation is necessarily restricted to a period of cold climate. If mound formation postdated development of the Holocene age soil, the Neoglacial is the only time when temperatures may have been depressed enough for mounds to form. If so, the period of mound formation, active mammal disturbance, and subsequent incipient soil development would have to be compressed into the very short time interval between the Neoglacial and the present. 


\section{Mammal Activity}

Every mound observed in this study exhibited strong bioturbation which destroyed soil horizons in both the buried and surface soils and therefore postdated mound formation and pedogenesis. The bioturbation ranged from complete mixing and destruction of soil structure, to the presence of krotovina within disturbed but recognizable soil horizons. The bioturbation typically (but not always) extended to the mound floor in a narrow zone which widened upwards like a funnel. The extent and age of bioturbation varied significantly. Young krotovina contained loose soil, organic debris, and scat. Older krotovina have been engulfed by calcium carbonate, causing them to be harder and with higher value colors. The disturbed zones within RWMCM1, BLRM2, BLRM4, and IPM2 contain large remnants of recognizable Bk horizons which appear to be floating "in place." In 8MFM2, large remnants of the Bk actually settled into the underlying disturbed soil.

\section{Secondary Processes}

A number of secondary erosional and/or depositional processes have contributed to the current physiography of mounded microtopography in this region. The continual transport and deposition of sediment at tunnel openings by fossorial rodents has likely contributed to the maintenance of the mounds, i.e., RGFM1, 8MFM4, IPM2. The loose soil deposited on the mound surfaces, and the increased vegetative growth, provide increased surface roughness and a lower wind velocity site for net deposition of eolian sediment. This is evident from the thin layer of eolian sand which covers the BLRM2 and BLRM4 mounds. '

Preferential intermound runoff on slopes has contributed to the development of the continuous, smooth profiles observed between the upslope mound and intermound boundaries. Runoff around the sides of the mounds has eroded somewhat steeper sides and toes resulting in slightly exaggerated mound heights. Slopewash processes fill the intermound areas in basins which receive sediment from surrounding hillsides. Mounds in these locations may ultimately be buried. 


\section{CONCLUSIONS}

The ESRP mounds are complex features only partially characterized by this study. Nevertheless, the data suggest that the mounds were formed by differential heaving of nearsurface, silty sediments caused by the growth of ice lenses during a climatic period of intense seasonal freezing. Hydraulic conductivity differences between fill sediments and the basement stratigraphy created a capillary barrier which effectively increased soil moisture at the site of future mound development. As the freezing front progressed downward in the sediment, this moisture was available for capillary migration and the subsequent growth of ice lenses. The growth of ice lenses parallel to the ground surface increased heaving pressures, causing upwarp of the surficial sediments. Additionally, some basalt boulders or alluvial gravels (depending on the basement stratigraphy) were heaved upward into the overlying sediments. The frost activity produced wedges, near-vertical fractures, and involutions in some buried soils. Mounds formed only where the necessary conditions were met: sufficient thickness of fine-grained sediments overlying a stratigraphy with higher hydraulic conductivity such that a capillary barrier ensured adequate moisture supply to the freezing front.

Following mound formation, the surficial sediments underwent a period of weathering sufficient to form a soil similar to other Holocene age soils observed on the ESRP. Fossorial rodents then inhabited the mounds significantly disturbing buried and surface soils. Mammal activities contribute significantly to mound maintenance by encouraging stronger vegetation growth and thus deposition of eolian sediment. Erosion of intermound areas on slopes contributes to increased height of the mounds by lowering of the intermound areas. Conversely, deposition of slopewash sediment in basins increases the height of intermound areas, thus lowering mound relief. Although development of mounds by frost heaving is not currently active, continued mammal activity and erosional and depositional processes continually effect mound morphology.

The mounds are younger than the glacial-outburst floods which inundated and scoured presently-mounded surfaces 16,900 years $\mathrm{BP}$. They also postdate the $\mathrm{Qb}$ terrace along the Big Lost River which is considered Late Pleistocene to earliest Holocene in age. The mounds predate pedogenesis of the surficial soils of Holocene age. Considering the inferred paleoclimates during the Late Pleistocene/Holocene interval, the mounds were probably formed after the last glacial maximum which occurred around 18,000 years ago, and prior to general warming beginning around 12,000 years ago. 


\section{REFERENCES}

Alldritt, J.E., 1979, Earth-Mound Characteristics and Possible Origins, Birch Creek Valley, EastCentral Idaho: M.A. thesis, Wichita State University, 113 p.

Arkley R.J., and Brown, H.C., 1954, The origin of Mima mound (hogwallow) microrelief in the far western states: Soil Science Society Proceedings, v. 18, no. 2, p. 195-199.

Beiswenger, J.M., 1991, Late Quaternary vegetational history of Grays Lake, Idaho: Ecological Monographs, v. 61, p. 165-182.

Berg, A.W., 1990, Formation of Mima mounds: A seismic hypothesis: Geology, v. 18, p. 281-284.

Berg, A.W., 1991, Reply on "Formation of Mima mounds: A seismic hypothesis": Geology, v. 19, p. 284-285.

Birkeland, P.W., 1984, Soils and Geomorphology, Oxford University Press, New York.

Black, C.A., 1965, Methods of Soil Analysis, Part 2: Chemical and Microbiological Properties, American Society of Agronomy, No. 9.

Black, R.F., 1976, Periglacial features indicative of permafrost: Ice and soil wedges: Quaternary Research, v. 6, p. 3-26.

Butler, R.D., Sorenson, C.J., and Dort Jr., W., 1982, Differentiation of morainic deposits based on geomorphic, stratigraphic, palynologic, and pedologic evidence, Lemhi Mountains, Idaho, USA, in Tills and Related Deposits, Proceedings of the INQUA Symposium on the Genesis and Lithology of Quaternary Deposits, (eds), Evenson E.B., Schluchter, Ch., and Rabassa, Jorge., A.A.Balkema/Rotterdam.

Cerling, T.E., Poreda, R.J., and Rathburn, S.L., 1994, Cosmogenic ${ }^{3} \mathrm{He}$ and ${ }^{21} \mathrm{Ne}$ age of the Big Lost River Flood, Snake River Plain, Idaho: Geology, v. 22, p. 227-230.

Chamberlain, E.J., and Gow, A.J., 1979, Effect of freezing and thawing on the permeability and structure of soils: Engineering Geology, v. 13, p. 73-92.

Clawson, K.L., Start, G.E., Ricks, N.R., 1989, Climatology of the Idaho National Engineering Laboratory, 2nd Edition, DOE.ID-12118.

Cox, G.W., 1984a, Mounds of Mystery: Natural History, v. 6, p 36-45.

Cox, G.W., 1984b, The distribution and origin of mima mound grasslands in San Diego County, California: Ecology, v. 65, no. 5, p. 1397-1405.

Cox G.W., and Gakahu, C.G., 1984, The formation of Mima mounds in the Kenya highlands- A test of the Dalquest-Scheffer hypothesis: Journal of Mammalogy, v. 65, no. 1, p. 149-152. 
Cox, G.W., and Roig, V.G., 1986, Argentinean Mima mounds occupied by Ctenomyid rodents: Journal of Mammalogy, v. 67, no. 2, p. 428-432.

Cox, G.W. and Allen, D.W., 1987, Soil translocation by pocket gophers in a Mima moundfield: Oecologia (Berline) v. 72, p. 207-210.

Cox, G.W. and V.B. Scheffer, 1991, Pocket Gophers and Mima terrain in North America: Natural Areas Journal, v. 11,no. 4, p. 193-199.

Dalquest, W.W., and Scheffer, V.V., 1942, The origin of the mima mounds of western Washington: J. of Geol., v. 50, no. 1, p. 68-84.

Dawson, A.G., 1992, Ice Age Earth: Late Quaternary Geology and Climate, Routledge, London and New York.

Dechert, T.V., McDaniel, P.A., and Falen, A.L., 1994, Aggradational and erosional history of the Radioactive Waste Management Complex at the Idaho National Engineering Laboratory, EGG-WM-11049.

Dort Jr., W., 1962, Multiple Glaciation of Southern Lemhi Mountains, Idaho - Preliminary Reconnaissance Report: Tebiwa, v. 5, no. 2., The Journal of the Idaho State College Museum, Pocatello, Idaho.

Dort Jr., W., 1968, Paleoclimatic implications of soil structures at the Wasden Site (Owl Cave): Tebiwa, v. 11, no. 1, p. 31-36.

Evenson, E.B., Cotter, J.F.P, and Clinch, J.M., 1982, "Glaciation of the Pioneer Mountains: a proposed model for Idaho:, in Bill Bonnichsen and R.M. Breckenridge, (eds.), Cenozoic Geology of Idaho: Idaho Bureau of Mines and Geology Bulletin 26, p. 653-665.

Falen, A.L. and Fosberg, M.A., 1989, Soil Characterization Laboratory Procedures, University of Idaho College of Agriculture, Miscellaneous Series No. 122.

Forman, S.L., et al., 1993, Timing of the late Quaternary glaciations in the Western United States based on the age of loess on the Eastern Snake River Plain, Idaho: Quaternary Research, v. 30, p. 30-37.

Fosberg, M.A., 1965, Characteristics of Patterned Ground in Wisconsin Time in a Chestnut Soil Zone of Southern Idaho: Soil Science, v. 99, p. 30-37.

Goh, T.B., St. Arnaud, R.J., and Mermut, A.R., 1993, Carbonates, in M.R., Carter, (ed), Soil Sampling and Methods of Analysis, Canadian Society of Soil Science, Lewis Publishers.

Hackett, W.R., et al, 1995, Geologic processes in the RWMC area, Idaho National Engineering Laboratory: Implications for long term stability and soil erosion at the Radioactive Waste Management Complex, EGG-WM-11430 Draft. 
Huntley, Nancy and Reichman, O.J., 1994, Effects of subterranean mammalian herbivores on vegetation: Journal of Mammalogy, v.75, n. 4, p. 852-859.

James, P.A, 1971, The measurement of soil frost-heave in the field, Technical Publication of the British Geomorphological Research Group.

Knechtel, M.M., 1952, Pimpled plains of eastern Oklahoma: G.S.S. Bulletin., v. 63, p. 689-700.

Knoll, K.M., 1977, Chronology of Alpine Glacier Stillstands, East-Central Lemhi Range, Idaho: A special publication of the Idaho State University Museum of Natural History, Pocatello, Idaho.

Kuntz, M.A, et al., 1990, Revised Geologic Map of the Idaho National Engineering Laboratory and Adjoining Areas, Eastern Idaho: U.S. Geological Survey Open File Report 90-333.

Lewis, G.C., 1986, Distribution and character of loess deposits in southern Idaho: University of Idaho, Research Bulletin 137.

Lewis G.C. and Fosberg, M.A, 1982, Distribution and character of loess and loess soils in southeastern Idaho, in Bill Bonnichsen and R.M. Breckenridge, (eds.), Cenozoic Geology of Idaho: Idaho Bureau of Mines and Geology Bulletin 26, p. 705-716.

Malde, H.E., 1961, Patterned ground of possible solifluction origin at low altitude in the western Snake River Plain, Idaho, in Short papers in the geological and hydrologic sciences: U.S. Geological Survey Professional Paper 424-B, p. B170-B173.

Malde, H.E., 1964, Patterned Ground in the Western Snake River Plain, Idaho, and Its Possible Cold Climate Origin: Geological Society of America Bulletin, v. 75, no.3, p. 191-207.

McDole, R.E., 1969, Loess deposits adjacent to the Snake River flood plain in the vicinity of Pocatello, Idaho: Ph.D. Dissertation, University of Idaho, Moscow.

McDole, R.E., Lewis, G.C., and Fosberg, M.A., 1973, Identification of paleosols and the Fort Hall Geosol in southeastern Idaho: Soil Sci. Soc. Amer. Proc., v. 37, p. 611-616.

Mielke, H.W., 1977, Mound building by pocket gophers (Geomyidae): their impact on soils and vegetation in North America: Journal of Biogeography, v.4, p. 171-180.

Moody, U.L., and Dort Jr., Wakefield, 1990, Microstratigraphic analysis of sediments and soils; Wasden archaeological site, eastern Snake River Plain, Idaho, in Lasca, N.Pl, and Donahue, J., eds., Archaeological geology of North America: Boulder, Colorado, Geological Society of America, Centennial Special Volume 4.

Nace, R.L., Morris, Deutsch, and Voegeli, P.T., 1956, Geography, Geology, and Water Resources of the National Reactor Testing Station, Idaho, Part 2, Geography and Geology, USGS Professional Paper 725. 
Newcomb, R.C., 1952, Origin of the Mima mounds, Thurston County region, Washington: Journal of Geology, v. 60, no. 1, p. 461-472.

Pewe, T.L., 1948, Origin of the mima mounds: Sci. Mo., v. 66, no. 4, p. 293-296.

Pierce, K.L., Fosberg, M.A., Scott, W.E., Lewis, G.C., and Colman, S.M., 1982, Loess deposits of southeastern Idaho: age and correlation of the upper two loess units, in Bill Bonnichsen and R.M. Breckenridge, (eds.), Cenozoic Geology of Idaho: Bureau of Mines and Geology Bulletin 26, p. 717-725.

Pierce, KL., and W.E. Scott, 1982, Pleistocene episodes of alluvial-gravel deposition, southeastern Idaho, in Bill Bonnichsen and R.M. Breckenridge, (eds.), Cenozoic Geology of Idaho: Bureau of Mines and Geology Bulletin 26, p. 685-702.

Pierce, K.L. and L.A. Morgan, 1992, The track of the Yellowstone Hotspot: Volcanism, Faulting, and Uplift, Regional Geology of Eastern Idaho and Western Wyoming: Geological Society of America Memoir, 179, P.K. Link et al., (eds.), p. 1-54.

Rathburn, S.L., 1989, Pleistocene glacial outburst flooding along the Big Lost River, east-central Idaho: University of Arizona, M.S. thesis.

Rathburn, S.L., 1991, Quaternary channel changes and paleoflooding along the Big Lost River, Idaho National Engineering Laboratory, EGG-WM-9909.

Rathburn, S.L., 1993, Pleistocene cataclysmic flooding along the Big Lost River, East-Central Idaho: Geomorphology, v. 8, p. 305-319.

Ritchie, A.M., 1953, The erosional origin of the Mima mounds of south-western Washington: Journal of Geology, v. 61, no. 1, p. 41-50.

Richmond, G.M, 1965, Glaciation of the Rocky Mountains. in Wright, H.E., Jr. and Frey, G. D. (eds), The Quaternary of the United States, pp. 217-230. Princeton University Press, Princeton, New Jersey.

Richmond, G.M., 1986, Stratigraphy and Chronology of Glaciations in Yellowstone National Park, in V. Sibrava, D.Q. Bowen and G.M Richmond, (eds), Quaternary Glaciations in the Northern Hemisphere, Pergamon Press.

Saucier, R.T., 1991, Comment on "Formation of Mima mounds: A seismic hypothesis": Geology, v. 19, p. 284.

Scheffer, V.B., 1947, The mystery of the Mima mounds: Scientific monthly, v. 65, no. 4, p. 283294.

Scott, W.E., 1982, Surficial Geologic Map of the Eastern Snake River Plain and adjacent Areas, $111^{\circ}$ to $115^{\circ} \mathrm{W}$., Idaho and Wyoming: U.S. Geological Survey Miscellaneous Investigations Series I-1372. 
Soil Conservation Service, 1974, Definitions and abbreviations for soil descriptions, USDA-SCS, West Technical Service Center, Portland Oregon.

Soil Survey Laboratory Staff, 1992, Soil Survey laboratory methods manual, Soil Survey Investigations Report No. 42, Soil Conservation Service.

Spackman, L.K., 1982, Genesis and Morphology of soils associated with Laramie Basin (Mimalike) mounds: M.S. thesis, University of Wyoming, Laramie, Wyoming, 81 p.

Tallyn, L.K, 1980, Scabland mounds of the Cheney quadrangle Spokane County, Washington, M.S. Thesis, Eastern Washington University, Cheney, Washington.

Thelin, G.P., and Pike, R.J., 1991, Landforms of the Conterminous United States - A digital shaded-relief portrayal, U.S. Geological Survey Miscellaneous Investigations Series Map I2206.

Thompson, R.S., Whitlock, Cathy, Bartlein, P.J., Harrison, S.P., and Spaulding, W.G., 1993, Climatic changes in the Western United States since 18,000 yr B.P.: in Wright Jr., H.E., Kutzbach, J.E., Webb III, T., Ruddiman, W.F., Street-Perrott, F.A., and Bartlein, P.J. eds, Global climates since the last glacial Maximum, University of Minnesota Press, Minneapolis.

Wallace, R.E., 1991, Ground-squirrel mounds and related patterned ground along the San Andreas fault in central California, U.S. Geological Survey Open File Report 91-149.

Washburn, A.L., 1956, Classification of patterned ground and review of suggested origins, Geological Society of America Bulletin, V. 67, p. 823-865.

Washburn, AL., 1980, Geocryology: A survey of periglacial processes and environments, John. Wiley and Sons, New York.

Washburn, A.L., 1988, Mima Mounds: An evaluation of proposed origins with special reference to the Puget Lowland, Washington Division of Geology and Earth Resources, Report of Investigations 29.

Wilson, M.D., 1977, Origin of Patterned Ground near Boise, Id., Geological Society of America, Rocky Mountain Section, Abstracts with Programs, Missoula, Mt. 


\section{Appendix A}

\section{Partial List of Mound Origin Research Since 1945}




\title{
Appendix A
}

\section{Partial List of Mound Origin Research Since $1945^{*}$}

\author{
1845 - Wilkes: \\ Indian burial grounds; "Savage Labor" \\ 1855 - Gibbs: \\ Growth of giant roots \\ 1874 - Le Conte: \\ Erosion associated with recession of an ice sheet \\ - Rogers: \\ Supraglacial rock melting into ice and filling of voids with \\ sediment \\ 1904 - Upham: \\ Terminal drift accumulation (Wisconsin age) \\ - Branner: \\ Concretionary action or construction by ants \\ 1907 - Hobbs: \\ "Mud-volcano" phenomena \\ 1913 - Bretz: \\ Silt in depressions of ice sheets left mounds upon melting of \\ the ice \\ 1928 - Nickiforoff: \\ Blistering of the surface by newly freezing water trapped \\ between two frozen layers in the soil (Siberia) \\ 1940 - Newcomb: \\ Result of fissure polygons of the Vashon ground ice \\ 1941 - Nickiforoff: \\ Blistering of surface by ground water under hydrostatic \\ pressure (California) \\ 1942 - Dalquest and Scheffer: \\ 1945 - Dietz: \\ Gopher/animal hypothesis \\ Sand collection about vegetation during lagoon filling (Gulf \\ coast and Washington State) \\ 1948 - Koons: \\ Gopher refuge from rising water table \\ - Pewe: \\ Periglacial forms from ice wedges \\ - Stallings: \\ Mound growth by gophers pulling dirt into their chambers \\ 1949 - Krinetzsky: \\ Wind and water action upon fluvial materials \\ - Price: \\ Bi-convex shape means animal activity
}


1952 - Knechtel:

- Newcomb:

1953 - Ritchie:

1954 - Arkley and Brown:

1964 - Malde:

1965 - Fosberg:

1967 - Murray:

- Ross et al.

1974 - Harksen and Christensen:

- Cain

1977 - Mielke

1978 - McFaul:

1980 - Tallyn:

1980 - Washburn:

1981 - Aten and Bollich:

1982 - Spackman:

???? - Reider:

1984 - Cox:

1988 - Washburn:
Water erosion and subsidence of ground adjacent to fissure polygons (Oklahoma)

Ice wedge expansion

Melted ice wedges used as channels by flood waters

Gophers built mounds in reaction to restricted root growth

Periglacial climates (Idaho)

Solifluction related to periglacial climate (Idaho)

Response of gophers to seasonally saturated soil (Colorado)

Puffs of soil formed by animals (Minnesota)

Developed under permafrost conditions during maximum extent of late Wisconsin glaciation (South Dakota)

Pedestal tree erosion (Louisiana)

Fossorial rodents (Geomyidae)

Periglacial environments acting upon a Histosol or bog, producing ice wedge polygons

Frost heaves formed in a periglacial climate

Result of water erosion along seasonal frost or desiccation cracks

Aggradational features formed from sediments later eroded from intermound areas (Texas)

Result of cryostatic pressure released through planes of weakness created by large fossil permafrost sand wedges (Wyoming)

Salt-diapirs induced by rising groundwater

Fossorial rodents (San Diego County, California)

Runoff erosion combined with vegetation anchoring (Puget prairies) 
1990 - Berg:

- Krantz:

1991 - Cox and Scheffer:

1991 - Wallace:

1992 - Cox et al.: seismic shaking on a rigid planar substratum

Free convection of water overlying a thaw front (patterned ground:polygons, stripes, circles)

Fossorial rodents (Western North America, Africa, South America)

Ground squirrels (Central California)

Fire Ants (Argentina)

This list was amended from Spackman (1982). This author did not review all references listed. Unless noted, the hypotheses pertain to the Mima mounds of Washington State. 


\section{Bibliography of References in Appendix A}

Arkley, R.J. and Brown, H.C., 1954, Origin of the Mima Mound (hogwallow) microrelief in the far western states, Soil Sci. Soc. Am. Proc., 18, 2, pp 159-199.

Aten, L.E. and Bollich, C. N., 1981, Archeological evidence for pimple (prairie) mound genesis, Science, 213, pp. 1375-1376.

Berg, A.W., 1990, Formation of mima mounds: A seismic hypothesis, Geology, 18, pp 281-284.

Branner, J.C., 1905, Natural mounds or hog "wallows", Science, 21, pp 524-526.

Bretz, J.H., 1913, Glaciation of the Puget Sound Region, Wash. St. Geol. Survey., Olympia, Bull. No. 8, pp 1-244.

Cain, R.H., 1974, Pimple mounds: a new viewpoint, Ecology, 55, 178-182.

Cox, G.W., 1984, The distribution and origin of mima mound grasslands in San Diego County, California, Ecology, 65, 5, p. 1397-1405.

Cox, G.W. and V.B. Scheffer, 1991, Pocket Gophers and Mima terrain in North America, Natural Areas Journal, 11, 4, pl 193-199.

Cox, G.W., Mills, J.N., and Ellis, B.A., Fire ants (Hymenoptera: Formicidae) as major agents of landscape development, Environmental Entomology, 21, 2, pp 281-286.

Dalquest, W.W., and Scheffer, V.V., 1942, The origin of the mima mounds of western Washington, J. of Geol., 50, 1, pp 68-84.

Dietz, R.S., 1945, The small mounds of the Gulf coast plain, Science, 102, pp 596-597.

Fosberg, M.A, 1965, "Characteristics of Patterned Ground in Wisconsin Time in a Chestnut Soil Zone of Southern Idaho", Soil Science, 99, pp. 30-37.

Gibbs, George, 1855, Report upon the geology of the central portion of Washington territory, in reports of explorations... for a railroad from the Mississippi river to the Pacific Ocean..., in 1853-1854: United States War Department, v.1, no. 2 pp 473-486.

Harksen, J.C. and Christensen, C.M., 1974, Proglacial frost action in west-central South Dakota, Abstracts with Programs, p. 512.

Hobbs, W.H., 1907, Some topographic features formed at the time of earthquakes, and the origin of mounds on the Gulf Plain, American Journal of Science, 23, pp. 245-256.

Knechtel, M.M., 1952, Pimpled plains of eastern Oklahoma, G.S.S. Bulletin., 63, pp 689-700.

Koons, F.C., 1948, The sand mounds of Louisiana and Texas, Sci. Mo., 66, 4, pp 297-300. 
Krantz, W.B., 1990, Self-organization manifest as patterned ground in recurrently frozen soils, Earth Science Reviews, 29, pp 117-130.

Krinetzsky, E.L., 1949, Origin of pimple mounds, Am. J. Sci., 247, pp 706-714.

Le Conte, J., 1874, On the great lava flow of the northwest and on the structure and age of the Cascade Mountains, American Journal of Science, 7, pp 365-367.

Malde, H.E., 1964, "Patterned Ground in the Western Snake River Plain, Idaho, and Its Possible Cold Climate Origin", Geological Society of America Bulletin 75,3, pp. 191-207.

McFaul, M., 1979, A geomorphic and pedological interpretation of the Mima-mounded prairies, South Puget Lowland, Washington state, M.A. thesis, University of Wyoming, Laramie.

Mielke, H.W., 1977, Mound building by pocket gophers (Geomyidae): their impact on soils and vegetation in North America, Journal of Biogeography, 4, p. 171-180.

Murray, D.F., 1967, Gravel mounds at Rocky Flats, Colorado, Mountain Geology, 4, pp 99-107.

Newcomb, R.C., 1940, Hypothesis for the periglacial fissure polygon origin of Tenino mounds Thurston County Washington, Geol. Newsletter. of Geol. Soc. of Oregon County, 6, p. 182.

Newcomb, R.C., 1952, Origin of the Mima mounds, Thurston County region, Washington, Journal of Geology, 60,1, pp 461-472.

Nickiforoff, D.C., 1928, The perpetually frozen subsoil of Siberia, Soil Science, 26, pp 61-78.

Nickiforoff, D.C., 1941, Hardpan and microrelief in certain soil complexes of California, U.S.D.A., Tech. Bull. 745.

Pewe, T.L., 1948, Origin of the mima mounds, Sci. Mo., 66, 4, pp 293-296.

Price, W.A., 1949, Pocket gophers as architects of mima (pimple) mounds of the western United States, Tex. J. of Sci., 1, 1, pp 1-17.

Ritchie, A.M., 1953, The erosional origin of the Mima mounds of south-Western Washington, Journal of Geology, 61, 1, pp 41-50.

Rogers, G.O., 1893, Drift mounds near Olympia, Washington, American Geologist, v.11-12, pp 393-399.

Ross, B.A., Tester, J.R., and Breckenridge, W.J., 1968, Ecology of Mima-type mounds in northwestern Minnesota, Ecology, 49, pp. 172-177.

Spackman, L.K, 1982, Genesis and Morphology of soils associated with Laramie Basin (Mimalike) mounds, M.S. thesis, University of Wyoming, Laramie, Wyoming. 
Stallings, J.H., 1948, The mima mounds, Sci. Mo., 66, pp 269-270.

Upham, W., 1904, Glacial and modified drift in and near Seattle, Tacoma, and Olympia, American Geologist, 34, pp. 203-214.

Tallyn, L.K., 1980, Scabland mounds of the Cheney quadrangle Spokane County, Washington, M.S. Thesis, Eastern Washington University, Cheney, Washington.

Wallace, R. E., 1991, Ground-squirrel mounds and related patterned ground along the San Andreas fault in central California, U.S. Geological Survey Open-file report 91-149.

Washburn, A.L., 1980, Geocryology, A survey of Periglacial Processes and Environments, Arnold, London/Halsted Press, New York.

Washburn, A.L., 1988, Mima Mounds: An evaluation of proposed origins with special reference to the Puget lowland, Washington Division of Geology and Earth Resources, Report of Investigations 29.

Wilkes, Charles, 1845, Puget sound and Okanogan, in: Narrative of the United States exploring expedition during the years 1838-1842, v. 4, Philadelphia, Lee and Blanchard, pp. 409-440. 
Appendix B

Field and Laboratory Data

B-1 


\begin{tabular}{|c|c|c|c|c|c|c|c|c|c|c|c|c|}
\hline $\begin{array}{l}\text { Site } \\
\text { Trench } \\
\text { Elevat } \\
\% \text { slop } \\
\text { Positi } \\
\text { Aspect }\end{array}$ & $\begin{array}{l}\text { distance } \\
\text { on } \\
\text { n }\end{array}$ & $\begin{array}{l}\frac{8 M F M 2}{40 \mathrm{~cm}} \\
\frac{1575 \mathrm{~m}}{1.5} \\
\frac{\text { Middle }}{\text { east }}\end{array}$ & $\begin{array}{l}\text { County } \\
\text { Locati } \\
\text { Parent } \\
\text { Vegeta } \\
\text { Hor. } r\end{array}$ & $\begin{array}{l}\text { late } \\
\text { on } \\
\text { ? }\end{array}$ & ial $\frac{\frac{B u t}{S E}}{\frac{S a b}{S g}}$ & $\frac{\frac{\text { te }}{\frac{x_{1}}{\text { orked }}}}{\frac{\text { orked }}{\text { ebrusf }}}$ & $\frac{\frac{3}{\text { Secti }}}{\frac{\text { loess ov }}{\text { winter }}}$ & $\frac{\text { on } 6,7}{\text { ar ali }}$ & $\frac{4 \mathrm{~N}, \mathrm{R} 29 \mathrm{E}}{\text { vial gravel }}$ & species & & \\
\hline Samp. & Depth & Horizon & Text. & Con & ist. & Lime & roots & Pores & Color & Structure & Boundary & $\%$ rock \\
\hline 1 & & $A$ & & 1 & & & 208 & & 10v0 & 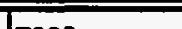 & & \\
\hline$\frac{1}{2}$ & & $\frac{A}{B k 1}$ & $\frac{1}{130}$ & $\frac{\mathrm{sh}}{\mathrm{sh}}$ & 50 & es & $\frac{m \text { m } 3 v i t}{1 v f f}$ & $=$ & LUYR $4 / 2$ & & & \\
\hline 3 & $30-66$ & Bk2 & $\mathrm{si1} / 25$ & sh & 5 & es & $\operatorname{trf}$ & $2 f$ & 10YR $5.5 / 3$ & 1or/2csbk & cs & 5 \\
\hline 4 & $66-94$ & $2 B C$ & 1 & sh & ss & es & $\operatorname{trfm}$ & $1 f$ & 10YR $5 / 3$ & massive & cs & $.5-15$ \\
\hline 5 & $94-126$ & $3 \mathrm{BCb}$ & csl & 10 & & es & - & - & 10YR $5 / 3$ & massive & as & 60 \\
\hline 6 & $126-141$ & $4 \mathrm{BCb}$ & cs ] & 10 & & & - & - & 10YR $7 / 3$ & massive & & 60 \\
\hline
\end{tabular}

Comments:

1. Intermound position

2. Units 4,5 , and 6 are clast supported with interstitial silt. The $4 B C$ horizon also has very fine ash mixed into the silt. Clasts forming the basal units are limestone. Many in the $4 B C$ are rotten and crumb le into powder when disturbed.

3. Laterally cont inuous to the $150 \mathrm{~cm}$ profile.

\begin{tabular}{|c|c|c|c|c|}
\hline $\begin{array}{c}\text { Samp. } \\
\text { No. }\end{array}$ & Depth & Horizon & $\mathrm{pH}$ & $\begin{array}{c}\mathrm{EC} \\
(\mathrm{Ms} / \mathrm{cm})\end{array}$ \\
\hline \hline 1 & $0-10$ & $\mathrm{~A}$ & 7.9 & 0.41 \\
\hline 2 & $10-30$ & $\mathrm{Bk} 1$ & 8.0 & 0.69 \\
\hline 3 & $30-66$ & $\mathrm{Bk} 2$ & 8.5 & 2.3 \\
\hline 4 & $66-94$ & $2 \mathrm{BC}$ & 8.5 & 6.6 \\
\hline 5 & $94-126$ & $3 \mathrm{BCb}$ & 8.7 & 14.2 \\
\hline 6 & $126-141$ & $4 \mathrm{BCb}$ & 8.8 & \\
\hline
\end{tabular}

\begin{tabular}{|c|c|c|c|c|c|c|c|c|c|c|c|c|}
\hline \multicolumn{2}{|c|}{$\begin{array}{l}\text { Site } \\
\text { Trench distance } \\
\text { Elevation } \\
\text { \% slope } \\
\text { Position } \\
\text { Aspect }\end{array}$} & $\begin{array}{l}\frac{8 \text { HFM2 }}{230 \mathrm{~cm}} \\
\frac{1575}{1.5} \\
\frac{\text { Middle }}{\text { east }}\end{array}$ & \multicolumn{3}{|c|}{$\begin{array}{l}\text { County } \\
\text { Location } \\
\text { Parent Materia } 1 \\
\text { Vegetation } \\
\text { Hor. ref. }\end{array}$} & \multicolumn{7}{|c|}{ 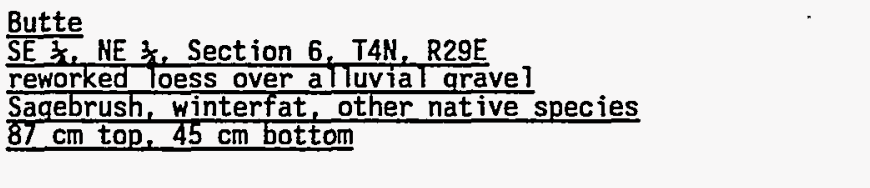 } \\
\hline \multirow{2}{*}{$\begin{array}{c}\text { Samp. } \\
\text { No. }\end{array}$} & \multirow{2}{*}{$\begin{array}{c}\text { Depth } \\
\text { (cm) }\end{array}$} & \multirow[t]{2}{*}{ Horizon } & \multirow[t]{2}{*}{ Text. } & \multicolumn{2}{|c|}{ Consist. } & \multirow[t]{2}{*}{ Lime } & \multirow[t]{2}{*}{ roots } & \multirow[t]{2}{*}{ Pores } & \multirow{2}{*}{$\begin{array}{l}\text { Color } \\
\text { (wet) }\end{array}$} & \multirow[t]{2}{*}{ Structure } & \multirow[t]{2}{*}{ Boundary } & \multirow[t]{2}{*}{$\%$ rock } \\
\hline & & & & dry & wet. & & & & & & & \\
\hline 1 & $0-10$ & $A$ & sil & 10 & & e & $2 \mathrm{vff}$ & - & & $2 \operatorname{mar}$ & Cs & \\
\hline 2 & $10-32$ & Bkl & sil/25 & h & ss Ds & es & $3 v f f$ & - & & $3 \mathrm{fmpl}$ & CS & $5-10$ \\
\hline 3 & $32-70$ & Bk? & sil $/ 20$ & $h$ & & es & $\operatorname{trf}$ & 2yff & & mass/1mcor & & $5-10$ \\
\hline 4 & $70-95$ & $2 B C$ & sil & sh & & es & $\operatorname{trf}$ & $2 v f f$ & & massive & & $5-10$ \\
\hline 5 & $95-132$ & $3 B C b$ & gravel & 10 & & es & - & - & & massive & & \\
\hline 6 & $132-$ & $4 \mathrm{BCb}$ & grave] & & & & & & & massive & & \\
\hline
\end{tabular}

Comments:

1. Intermound position

\begin{tabular}{|c|c|c|c|c|c|c|c|c|c|c|c|c|}
\hline $\begin{array}{l}\text { Site } \\
\text { Trench } \\
\text { Elevati } \\
\text { X slope } \\
\text { Positio } \\
\text { Aspect }\end{array}$ & $\begin{array}{l}\text { distance } \\
\text { on }\end{array}$ & $\begin{array}{l}\frac{8 \text { BHFM2 }}{380 \mathrm{~cm}} \\
\frac{1575}{1.5} \\
\frac{\text { Middie }}{\text { east }}\end{array}$ & $\begin{array}{l}\text { Count } \\
\text { Locat } \\
\text { Paren } \\
\text { Veget } \\
\text { Hor. }\end{array}$ & ion & ial & $\begin{array}{l}\text { Butte } \\
\frac{\text { SE 3. }}{\text { Sewior }} \\
\text { Sageb } \\
\frac{77 \mathrm{~cm}}{77}\end{array}$ & $\frac{\text { ed }}{\text { ush, }}$ & $\frac{\text { Sect }}{\frac{\text { ss ov }}{\text { inter }}}$ & 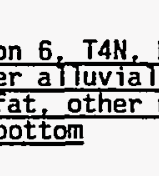 & $\frac{\frac{\mathrm{R} 29 \mathrm{E}}{\text { gravel }}}{\text { native speci }}$ & & \\
\hline $\begin{array}{c}\text { Samp. } \\
\text { No. }\end{array}$ & $\begin{array}{l}\text { Depth } \\
\text { (cm) }\end{array}$ & Horizon & Text. & $\begin{array}{l}\text { Cons } \\
\text { dry }\end{array}$ & ist. & Lime & roots & Pores & $\begin{array}{l}\text { Color } \\
\text { (wet) }\end{array}$ & Structure & Boundary & $\%$ rock \\
\hline 1 & $0-7$ & $A$ & sil & 10 & & & $2 \mathrm{fm}$ & $=$ & 10YR $3 / 3$ & $2 \mathrm{fmgr}$ & cs & \\
\hline 2 & $7-28$ & Bkl & sil/10 & sh & Ss os & & $2 \mathrm{fm}$ & - & 10YR $5 / 3$ & 3finshk & CW & 5 \\
\hline 3 & $28-60$ & Bk? & sill & h & sos & & if & $2 v f f$ & 10YR $4,5 / 3$ & mass/mcsbk & qs & 5 \\
\hline 4 & $60-73$ & $2 B C$ & sil $/ 20$ & sh & SS DS & & - & lvf & 10YR $4 / 3$ & massive & gs & \\
\hline 5 & $73-88$ & $3 \mathrm{BCb}$ & $\mathrm{sil} / 15$ & sh & SOS & & $t$ & trf & 10YR $4 / 3$ & massive & QW & \\
\hline 6 & $88-122$ & $4 \mathrm{BCb}$ & $\mathrm{si1} / 20$ & sh & sos & & - & $t f$ & 10YR $4 / 3$ & massive & & 50 \\
\hline
\end{tabular}


Comments:

1 . Intermound position

2. The section from $445-540$ is disturbed. It is not a fresh disturbance, as no nest is evident, and weak pedogenesis has created a Bwk in the upper part. The disturbance extends from the surface to the basal gravels.

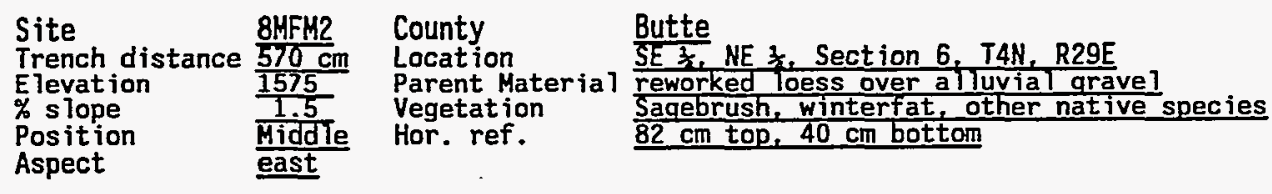

\begin{tabular}{|c|c|c|c|c|c|c|c|c|c|c|c|c|}
\hline Samp. & Depth & Horizon & Text. & Cons & ist. & Lime & roots & Pores & Color & Structure & Boundary & $\%$ rock \\
\hline & & & & dry & wet & & & & & & & \\
\hline 1 & $0-10$ & A & sil & 10 & s_ns & & & - & $10 Y R 3 / 3$ & & as & 5 \\
\hline 2 & $10-24$ & $B k 1$ & sil/15 & h & s_os & & 2fme & $=$ & 10YR $6 / 3$ & $3 \mathrm{fsbk} / 2 \mathrm{~g}]$ & as & 5 \\
\hline 3 & $24-46$ & $B k 2$ & sil/15 & sh & & & $2 \mathrm{fm}$ & $2 f$ & $10 Y R \quad 6 / 3$ & $2 m c s b k$ & gs & \\
\hline 4 & $46-78$ & $B C$ & si $/ 15$ & sh & Ss os & & trf & $2 f$. & IOYR $5 / 3$ & mass/3cor & CS & 5 \\
\hline 5 & $78-100$ & $3 \mathrm{BCb}$ & sil & 10 & & & - & & 10YR $4 / 3$ & massive & $\underline{q W}$ & 10 \\
\hline 6 & $100-122$ & $4 B C b$ & cs 1 & sh & & & - & & 10YR $4 / 3$ & massive & & 50 \\
\hline
\end{tabular}

Comments:

1. Mound/intermound boundary position

2. At $580 \mathrm{~cm}$, the upper four horizons are strongly mixed.

3. At $665 \mathrm{~cm}$, the BK1 is overla in by a mixed soil in which a weak BW has developed, and a weakly granular $A$ horizon. The bottom of the $B K 2$ is destroyed down into the $B C$. Remnant top and bottom contacts are very irregular.

4. At $690 \mathrm{~cm}$, the mixed area is larger and includes all of the BC.

5. The mixed soil above the BK1 thickens and there is more disturbance in the BK. At $790 \mathrm{~cm}$, the BK units dive to a lower position. Remnants of the BK are found at this deeper position to about 1100 un which is the opposite side of the disturbed zone

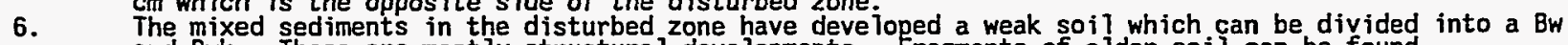
and Bwk. These are mostly structural developments. Fragments of oider soif can be found throughout.

\begin{tabular}{|c|c|c|c|c|}
\hline $\begin{array}{c}\text { Samp. } \\
\text { No. }\end{array}$ & Depth & Horizon & $\mathrm{pH}$ & $\begin{array}{c}\text { EC } \\
(\mathrm{Ms} / \mathrm{cm})\end{array}$ \\
\hline \hline 1 & $0-10$ & $\mathrm{~A}$ & 8.0 & 0.33 \\
\hline 2 & $10-24$ & $\mathrm{Bki}$ & 8.1 & 0.68 \\
\hline 3 & $24-46$ & $\mathrm{Bk} 2$ & 8.8 & 1.69 \\
\hline 4 & $46-78$ & $\mathrm{BC}$ & 8.6 & 5.97 \\
\hline 5 & $78-100$ & $3 \mathrm{BCb}$ & 8.7 & 9.43 \\
\hline 6 & $100-122$ & $4 \mathrm{BCb}$ & 8.6 & 7.6 \\
\hline
\end{tabular}

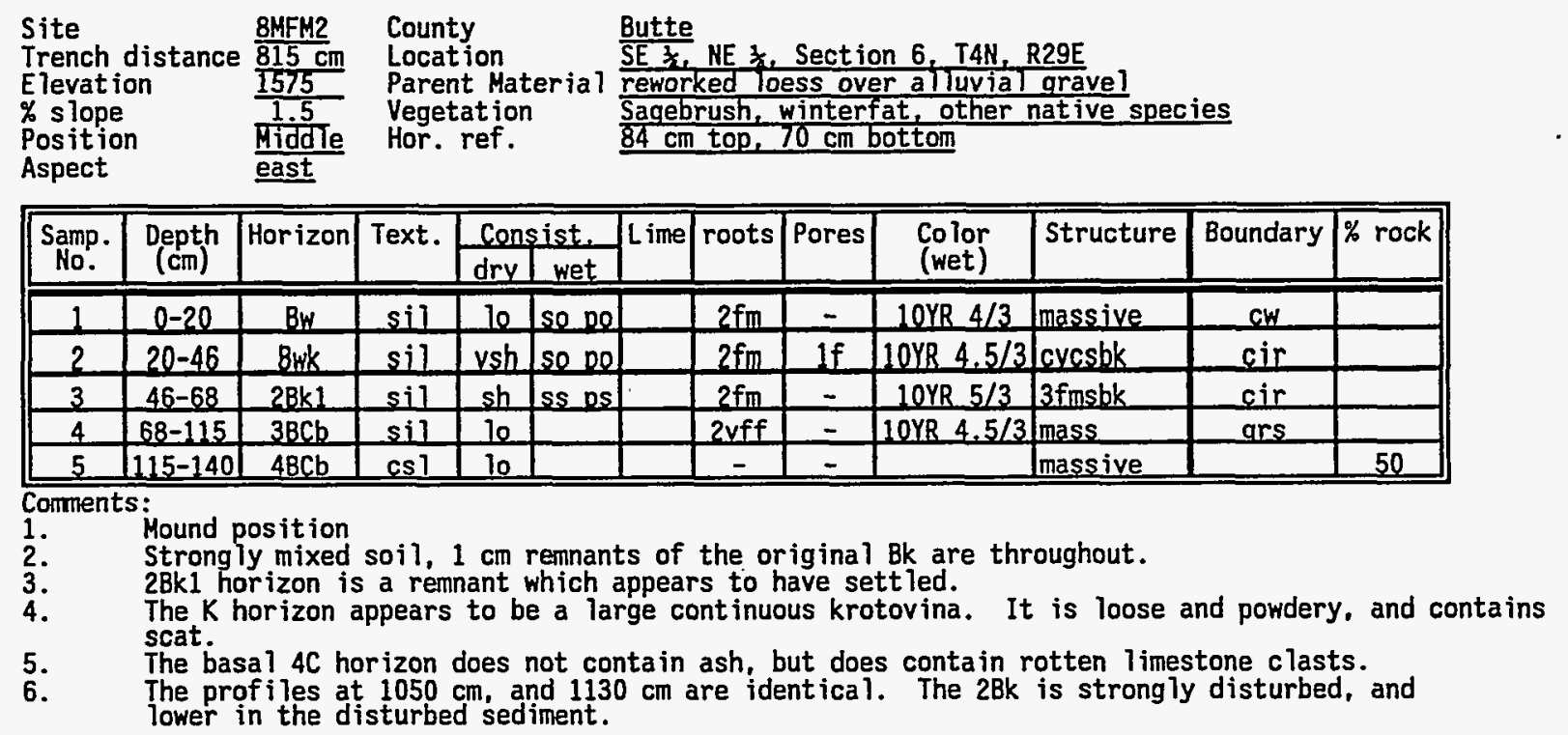




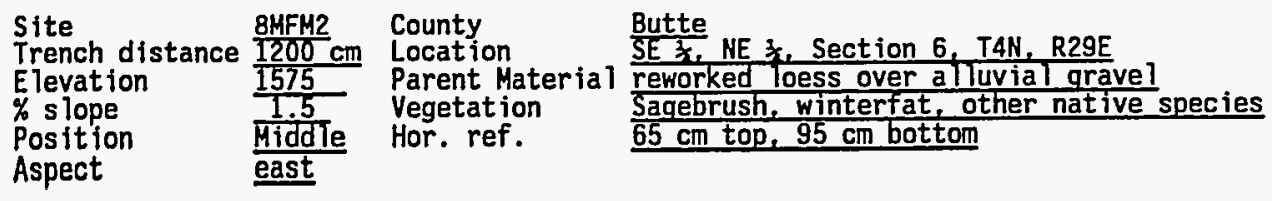

\begin{tabular}{|c|c|c|c|c|c|c|c|c|c|c|c|c|}
\hline Samp. & Depth & Horizon & Text. & Cons & ist. & Lime & roots & Pores & Color & Structure & Boundary & $\%$ rock \\
\hline No. & & & & dry & wet & & & & & & & \\
\hline 1 & $0-7$ & A & & 10 & & & $2 f$ & & & $1 \mathrm{fgr}$ & sir & \\
\hline 2 & $7-30$ & $\mathrm{Bw}$ & & h & & & $2 f$ & & & mass & sir & \\
\hline 3 & $30-45$ & $2 B k 1$ & & $h$ & & & $2 \mathrm{fm}$ & & & 3 fmsble & cir & \\
\hline 4 & $45-70$ & $28 \mathrm{k} 2$ & & vsh & & & if & $2 f$ & & 3 masbk & aws & \\
\hline 5 & $70-112$ & $K$ & & 10 & & & $2 f$ & & & massive & aw & \\
\hline 6 & $112-145$ & $\mathrm{BC}$ & & 10 & & & $=$ & & & massive & gs & 50 \\
\hline 7 & $145-160$ & $2 \mathrm{BCb}$ & & 10 & & & $\underline{-}$ & & & massive & & 50 \\
\hline
\end{tabular}

\section{Comments:}

Site BMFH2 County Butte

Trench distance $\frac{8 M 40}{1340} \mathrm{~cm}$ Location $\frac{\text { BUtte }}{\mathrm{SE} \frac{1}{x}}$ NE 3 , Section 6, T4N, R29E

Elevation Parent Material reworked loess over alluvial aravel

\% slope T.5 Vegetation Sagebrush, winterfat, other native species

Position Middle Hor. ref. $\quad 55 \mathrm{~cm}$ top, $100 \mathrm{~cm}$ bottom

Aspect east

\begin{tabular}{|c|c|c|c|c|c|c|c|c|c|c|c|c|}
\hline \multirow{2}{*}{$\begin{array}{l}\text { Samp. } \\
\text { No. }\end{array}$} & \multirow{2}{*}{$\begin{array}{c}\text { Depth } \\
\text { (cm) }\end{array}$} & \multirow[t]{2}{*}{ Horizon } & \multirow[t]{2}{*}{ Text. } & \multicolumn{2}{|c|}{ Consist. } & \multirow[t]{2}{*}{ Lime } & \multirow[t]{2}{*}{ roots } & \multirow[t]{2}{*}{ Pores } & \multirow{2}{*}{$\begin{array}{l}\text { Color } \\
\text { (wet) }\end{array}$} & \multirow[t]{2}{*}{ Structure } & \multirow[t]{2}{*}{ Boundary } & \multirow[t]{2}{*}{$\%$ rock } \\
\hline & & & & dry & wet & & & & & & & \\
\hline 1 & $0-20$ & $B y$ & sil & ysh & & & $1 \mathrm{vffm}$ & & 10YR $4 / 3$ & massive & $\mathrm{CW}$ & 10 \\
\hline 2 & $20-40$ & $2 \mathrm{BkL}$ & si]/15 & $h$ & ss os & & $2 \mathrm{fm}$ & & & $3 \mathrm{fmsbk}$ & CS & 5 \\
\hline 3 & $40-90$ & $2 \mathrm{Bk}$ ? & sil $/ 15$ & $h$ & ss os & & tr & Ivff & & 2mcsbk & CS & 5 \\
\hline 4 & $90-140$ & $B C$ & sid/25 & & 50 & & - & & & massive & $\mathrm{cW}$ & $<5$ \\
\hline 5 & $140-155$ & $2 \mathrm{BCb}$ & gravel & & & & & & & massive & & 50 \\
\hline
\end{tabular}

Comments:

1. Surface horizon, Bw, is continuation of bioturbated soil.

2. At $1380 \mathrm{~cm}$, a crack extends from the $\mathrm{BC}$ up to the $\mathrm{Bw}$. It is not as clear as the crack at $1210 \mathrm{~cm}$ and trends $N 3 O E$ rather than N3OW. Several clasts appear to be rotated into an orientation paralle to the crack.

3. Krotovina def ine the boundary between the BK2 and the BC from the disturbed zone to $1330 \mathrm{~cm}$. No

\begin{tabular}{|c|c|c|c|c|c|c|c|c|c|c|c|c|}
\hline $\begin{array}{l}\text { Site } \\
\text { Trench } \\
\text { Elevati } \\
\text { \% slope } \\
\text { Positio } \\
\text { Aspect }\end{array}$ & $\begin{array}{l}\text { distance } \\
\text { on } \\
\text { n }\end{array}$ & $\begin{array}{l}\frac{8 \text { MFH2 }}{1510 \mathrm{~cm}} \\
\frac{1575}{1.5} \\
\frac{\text { Middle }}{\text { east }}\end{array}$ & $\begin{array}{l}\text { Count } \\
\text { Locat } \\
\text { Paren } \\
\text { Veget } \\
\text { Hor. }\end{array}$ & $\begin{array}{l}\text { ion } \\
\text { Hat } \\
\text { ation } \\
\text { ref. }\end{array}$ & ial & $\frac{\frac{\text { Butte }}{\text { SE } x_{1}}}{\frac{\text { reworl }}{\text { Sagebr }}}$ & $\frac{\text { NE } \frac{1}{x / 1}}{\frac{\operatorname{ked} l o}{\text { rush, }}}$ & $\frac{\text { Sectio }}{\frac{\text { ess ove }}{\text { winterf }}}$ & \begin{tabular}{l|l}
6, T4N, \\
a
\end{tabular} & $\frac{\text { R29E }}{\frac{\text { gravel }}{\text { native spec }}}$ & ies & \\
\hline $\begin{array}{c}\text { Samp. } \\
\text { Ho. }\end{array}$ & $\begin{array}{l}\text { Depth } \\
(\mathrm{cm})\end{array}$ & Horizon & Text. & $\frac{\text { Cons }}{d r y}$ & wet. & Lime & roots & Pores & $\begin{array}{l}\text { Color } \\
\text { (wet) }\end{array}$ & Structure & Boundary & $\%$ rock \\
\hline 1 & $0-23$ & A & & 10 & & & & & & & & \\
\hline 2 & $23-45$ & $B k 1$ & & & & & & & & $3 \mathrm{fmsbk}$ & & $<5$ \\
\hline 3 & $45-62$ & Bk? & & & & & & & & 2mcsblk & & \\
\hline 4 & $62-89$ & $8 \times 3$ & & & & & & $2 f$ & & Imesblk & & \\
\hline 5 & $89-136$ & $B C$ & & & & & & & & mass & & \\
\hline 6 & $136-140$ & $2 B C$ & gravel & & & & & & & mass & & \\
\hline
\end{tabular}

Comments:

1. Mound position, on the downslope side of the bioturbated zone.

2. Surface sediments are mixed.

\begin{tabular}{|c|c|c|c|c||}
\hline $\begin{array}{c}\text { Samp. } \\
\text { No. }\end{array}$ & Depth & Horizon & $\mathrm{pH}$ & $\begin{array}{c}\mathrm{EC} \\
(\mathrm{mS} / \mathrm{cm})\end{array}$ \\
\hline \hline 1 & $0-23$ & $\mathrm{~A}$ & 7.9 & 0.42 \\
\hline 2 & $23-45$ & $\mathrm{Bk} 1$ & 7.9 & 0.29 \\
\hline 3 & $45-62$ & $\mathrm{Bk} 2$ & 8.2 & 0.33 \\
\hline 4 & $62-87$ & $\mathrm{Bk} 3$ & 8.6 & 0.49 \\
\hline 5 & $87-136$ & $\mathrm{BC}$ & 8.7 & 10.3 \\
\hline 6 & $136-140$ & $2 \mathrm{BC}$ & 8.9 & 8.2 \\
\hline
\end{tabular}




\begin{tabular}{|c|c|c|c|c|c|c|c|c|c|c|c|c|}
\hline $\begin{array}{l}\text { Site } \\
\text { Trench } \\
\text { Elevati } \\
\% \text { slope } \\
\text { Positio } \\
\text { Aspect }\end{array}$ & $\begin{array}{l}\text { distance } \\
\text { on } \\
n\end{array}$ & $\begin{array}{l}\frac{8 M F H 2}{1840 \mathrm{~cm}} \\
\frac{1575}{1.5} \\
\frac{1.5}{\text { Middle }} \\
\text { east }\end{array}$ & $\begin{array}{l}\text { Count } \\
\text { Locat } \\
\text { Paren } \\
\text { Veget } \\
\text { Hor. }\end{array}$ & $\begin{array}{l}\text { Hon } \\
\text { Mat } \\
\text { ation } \\
\text { ref. }\end{array}$ & rial & $\begin{array}{l}\frac{\text { Butte }}{\text { SE } \frac{1}{x_{1}}} \\
\frac{\text { rewor }}{\text { Sageb }} \\
\frac{19 \mathrm{Cm}}{19}\end{array}$ & $\frac{\text { NE } \frac{1}{x}}{\frac{\operatorname{ked} 10}{\text { rush, }}}$ & $\frac{\text { Sectic }}{\text { ess ove }}$ & $\frac{6, \text { T4N, }}{\text { a|luvia }}$ & $\frac{\frac{\mathrm{R} 29 \mathrm{E}}{\text { gravel }}}{\text { native spec }}$ & ies & \\
\hline $\begin{array}{l}\text { Samp. } \\
\text { No. }\end{array}$ & $\begin{array}{l}\text { Depth } \\
(\mathrm{cm})\end{array}$ & Horizon & Text. & Cons & $\begin{array}{l}\text { ist. } \\
\text { wet }\end{array}$ & Lime & roots & Pores & $\begin{array}{l}\text { Color } \\
\text { (wet) }\end{array}$ & Structure & Boundary & $\%$ ro \\
\hline 1 & $0-6$ & $A$ & & & & & & & & Ifar & & \\
\hline 2 & $6-17$ & $\mathrm{Bk} 1$ & & 10 & & & & & & 3 fsbk & & \\
\hline 3 & $17-69$ & Bk? & & & & & & & & 3 mesbk & & \\
\hline 4 & $69-118$ & $B C$ & & $h$ & & & & & & massive & & 5 \\
\hline 5 & $118-136$ & $2 \mathrm{BCb}$ & grave? & & & & & & & & & 50 \\
\hline
\end{tabular}

\section{Comments:}

1. Mound/intermound boundary position.

2. A is discontinuous

3. Ash in the $2 B C$

4. At this point, the Bk units are difficult to differentiate, and transition into a single Bk overlain

5. by a BW and more cont inuous $A$

5. The $B C$ is laterally consistent from the central disturbed zone to the right end of the trench.

\begin{tabular}{|c|c|c|c|c|c|c|c|c|c|c|c|c|}
\hline $\begin{array}{l}\text { Site } \\
\text { Trench } \\
\text { Elevat } \\
\% \text { slope } \\
\text { Positic } \\
\text { Aspect }\end{array}$ & $\begin{array}{l}\text { distance } \\
\text { on } \\
\text { n }\end{array}$ & 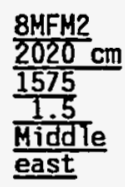 & $\begin{array}{l}\text { Count } \\
\text { Locat } \\
\text { Paren } \\
\text { Veget } \\
\text { Hor. }\end{array}$ & $\begin{array}{l}y \\
\text { ion } \\
t \text { Mat } \\
\text { ation } \\
\text { ref. }\end{array}$ & ial & 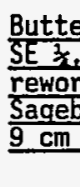 & $\frac{\text { NE } \frac{z_{2}}{\text { ked lo }}}{\text { rush, }}$ & $\frac{\text { Sectic }}{\text { ess ove }}$ & $\begin{array}{l}\text { on } 6 \text {, T4N, } \\
\text { er alluvial } \\
\text { fat, other } \\
\text { bottom }\end{array}$ & $\frac{\frac{\text { R29E }}{\text { gravel }}}{\text { native spe }}$ & ies & \\
\hline Samp. & Depth & Horizon & Text. & Cons & & Lime & roots & Pores & Color & Structure & Boundary & $\%$ rock \\
\hline & & & & dry & wet & & & & (wet) & & & \\
\hline 1 & $0-5$ & A & & & & & & & & $2 f a r$ & & \\
\hline 2 & $5-20$ & $B w$ & & & & & & & & & & \\
\hline 3 & $20-70$ & $8 k 1$ & $\mathrm{sil} / 15$ & h & & & & & 10YR $4 / 3$ & $2-3$ fmsbk & & \\
\hline 4 & $70-125$ & $B C$ & sil & 10 & ss Do & & & & 10 YR $4.5 / 3$ & massive & & 5 \\
\hline 5 & 125-139 & $2 \mathrm{BCb}$ & aravel & & & & & & & & & 50 \\
\hline
\end{tabular}

Comments:

1. Downs lope intermound position.

2. Weaker soil development than ups lope profiles.

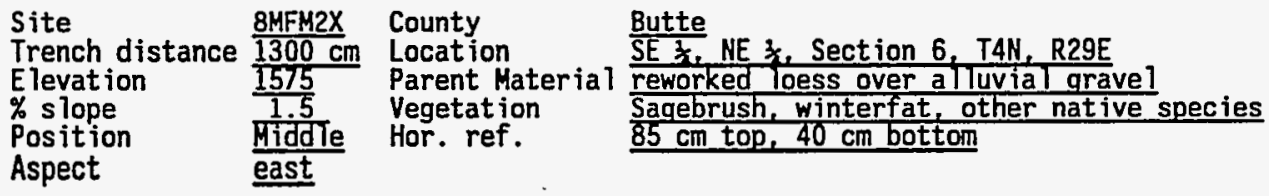

\begin{tabular}{|c|c|c|c|c|c|c|c|c|c|c|c|c|}
\hline $\begin{array}{l}\text { Samp. } \\
\text { No. }\end{array}$ & $\begin{array}{l}\text { Depth } \\
\text { (cm) }\end{array}$ & Horizon & Text. & Con & $\begin{array}{l}\text { ist. } \\
\text { wet }\end{array}$ & Lime & roots & Pores & $\begin{array}{l}\text { Color } \\
\text { (wet) }\end{array}$ & Structure & Boundary & $\%$ rock \\
\hline 1 & $0-28$ & $B W$ & sil & 10 & SS DS & & $3 \mathrm{fm}$ & & 10YR4.5/3 & mass & cS & $<5$ \\
\hline 2 & $28-48$ & $B k 1$ & sil & $h$ & ss os & & $2 f m$ & & 10YR $5.5 / 3$ & 3 fmsbk & cs & $<5$ \\
\hline 3 & $48-86$ & Bk? & sil/15 & sh & $s p$ & & & $2 f$ & 10YR $5.5 / 3$ & $2 \mathrm{fmsbk}$ & cs & $<5$ \\
\hline 4 & $86-103$ & $B C$ & sil & & ss os & & & & $10 Y R 5 / 3$ & massive & $c$ & $<5$ \\
\hline 5 & $103-125$ & $2 \mathrm{BCb}$ & sil/15 & & & & & $3 f$ & 10YR $4.5 / 4$ & $\begin{array}{l}\text { mass/2fma } \\
\text { bk }\end{array}$ & & \\
\hline
\end{tabular}

Comments:

1. 8MFM2X is a cross trench oriented across the slope. This position intersects the 8MFM2 trench

2. The Bk horizons dip toward the intermound, following the surface dip.

3. The surface is highly disturbed and mixed.

4. Units correlate laterally to the $1160 \mathrm{~cm}$ and $1010 \mathrm{~cm}$ positions, except for the presence of a discont inuous $A$ horizon. The $2 B k 1$ dips following the surface. A krotovina has disrupted the $2 B C$. 


\begin{tabular}{||c|c|c|c|c|}
\hline $\begin{array}{c}\text { Samp. } \\
\text { No. }\end{array}$ & Depth & Hor izon & $\mathrm{pH}$ & $\begin{array}{c}\mathrm{EC} \\
(\mathrm{mS} / \mathrm{cm})\end{array}$ \\
\hline \hline 1 & $0-28$ & $\mathrm{BW}$ & 7.9 & 1.02 \\
\hline 2 & 28048 & $\mathrm{BK} 1$ & 8.0 & 0.38 \\
\hline 3 & $48-86$ & $\mathrm{BK} 2$ & 8.1 & 6.02 \\
\hline 4 & $86-103$ & $\mathrm{BC}$ & 8.4 & 7.9 \\
\hline 5 & $103-125$ & $2 \mathrm{BCb}$ & 8.5 & 10.2 \\
\hline
\end{tabular}

\begin{tabular}{|c|c|c|c|c|c|c|c|c|c|c|c|c|}
\hline $\begin{array}{l}\text { Site } \\
\text { Trench } \\
\text { Elevati } \\
\% \text { slope } \\
\text { Positio } \\
\text { Aspect }\end{array}$ & listance & $\begin{array}{l}\frac{8 M F H 2 X}{870 \mathrm{~cm}} \\
\frac{1.5}{\text { Middle }} \\
\frac{\text { east }}{2}\end{array}$ & $\begin{array}{l}\text { Count } \\
\text { Locat } \\
\text { Parer } \\
\text { Veget } \\
\text { Hor. }\end{array}$ & $\begin{array}{l}\text { Mat } \\
\text { Mtion } \\
\text { ref. }\end{array}$ & iaj & $\frac{\frac{\text { Butte }}{\text { SE } x_{1}}}{\frac{\text { rewor }}{\text { Sagebr }}}$ & $\frac{\text { NE } \frac{3}{2}}{\frac{\operatorname{sed} 10}{\text { rush. }}}$ & $\frac{\text { Sectio }}{\text { ess ove }}$ & $\begin{array}{c}6, \text { T4N, } \\
\text { athuvia } \\
\text { t. other } \\
\text { ttom }\end{array}$ & $\frac{\frac{\mathrm{R} 29 \mathrm{E}}{\text { gravel }}}{\text { native spec }}$ & ies & \\
\hline $\begin{array}{c}\text { Samp. } \\
\text { Ho. }\end{array}$ & $\begin{array}{l}\text { Depth } \\
\text { (cm) }\end{array}$ & Horizon & Text. & Cons & $\begin{array}{l}\text { ist. } \\
\text { wet }\end{array}$ & Lime & roots & Pores & $\begin{array}{l}\text { Color } \\
\text { (wet) }\end{array}$ & Structure & Boundary & $\%$ rock \\
\hline 1 & $0-25$ & $A B$ & & 10 & & & & & & & & \\
\hline 2 & $25-54$ & Bu & & ysh & & & & & & & & \\
\hline 3 & $54-82$ & $B k$ & & & & & & & & & & \\
\hline 4 & $82-92$ & $2 B C$ & & & & & & & & & & \\
\hline
\end{tabular}

Comments:

1. $\quad A B$ and $B W$ horizons are comprised of mixed soil.

2. A large krotovina extends from this position to the right end of the trench.

3. The structure of the BK changes, so that on ly one BK unit is recognized.

4. This profile extends to about $630 \mathrm{~cm}$.

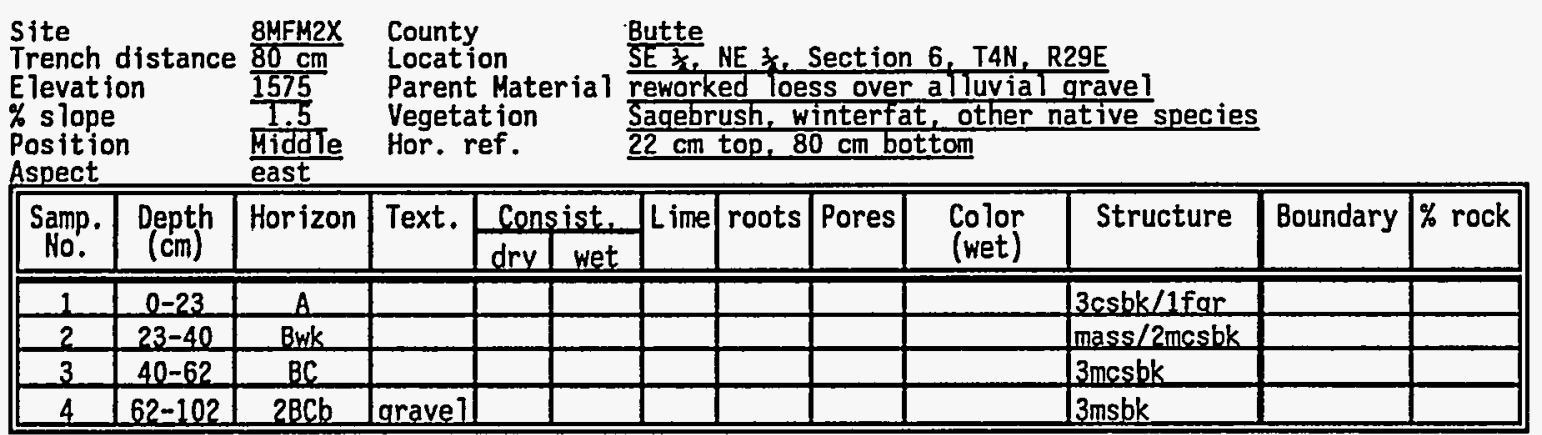

Comments:

1. Intermound position

2. Surface edge of mound is at $630 \mathrm{~cm}$. This profile extends to that point. Between $630 \mathrm{~cm}$ and the

right end of the trench, the surface horizons are comprised of mixed soil.

3. Although the Bk horizon extends into the mound, (rising parallel to the soil surface) the structure is not as well developed here. There is only one BK horizon as opposed to two BK in the mound profiles.

\begin{tabular}{|c|c|c|c|c|c|c|c|c|c|c|c|c|}
\hline $\begin{array}{l}\text { Site } \\
\text { Trench } \\
\text { Elevati } \\
\text { \% s lope } \\
\text { Pos itio } \\
\text { Aspect }\end{array}$ & istance & $\begin{array}{l}\frac{8 M F M 4}{28 \mathrm{~cm}} \\
\frac{1554}{1.5} \\
\frac{\text { Middle }}{\text { east }}\end{array}$ & $\begin{array}{l}\text { Coun } \\
\text { Loca } \\
\text { Pare } \\
\text { Vege } \\
\text { Hor. }\end{array}$ & $\begin{array}{l}\text { ion } \\
\text { Mat } \\
\text { tion } \\
\text { ref. }\end{array}$ & ial & $\frac{\frac{\text { Butte }}{\text { SE } x_{\text {. }}}}{\frac{\text { rewor }}{\text { Sageb }}}$ & 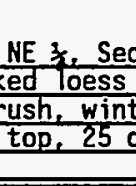 & $\frac{\text { tion }}{\text { over }}$ & 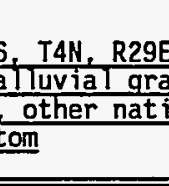 & avel & & \\
\hline $\begin{array}{l}\text { Samp. } \\
\text { No. }\end{array}$ & $\begin{array}{l}\text { Depth } \\
\text { (cm) }\end{array}$ & Horizon & Text. & Cons & ist. & Lime & roots & Pores & $\begin{array}{l}\text { Color } \\
\text { (wet) }\end{array}$ & Structure & Boundary & $\%$ rock \\
\hline 1 & $0-2$ & A & sil & 10 & so no & e & Ivff & & 10YR $3 / 3.5$ & 10 & cs & \\
\hline 2 & $2-16$ & $B y$ & sil & so & ss ns & es & $3 y f f, 2 m$ & & $10 Y R 3 / 3$ & 1 fmsbk & gs & $\leq 10$ \\
\hline 3 & $16-45$ & Buk & sil & sh & SS DS & es & $2 \mathrm{vff}, 1 \mathrm{~m}$ & & 10YR $3 / 4$ & 2 fmsbk & cs & \\
\hline 4 & $45-63$ & $2 B k$ & sil & $h$ & ss ps & es & Ivff & & 10YR $4 / 3$ & 2 fmsbk & & $>60$ \\
\hline
\end{tabular}

Comments:

1. Intermound position

2. Trench floor below $63 \mathrm{~cm}$ is comprised of very hard cemented gravels with/orange tinted caliche

3. Basal gravels are poorly sorted, subrounded, <1m thick caliche coats on bottoms - 7 imestone.

4. Interstices filled with silt. 


\begin{tabular}{|c|c|c|c|c|c|c|c|c|c|c|c|c|}
\hline $\begin{array}{l}\text { Site } \\
\text { Trench } \\
\text { Elevati } \\
\% \text { slope } \\
\text { Positio } \\
\text { Aspect }\end{array}$ & $\begin{array}{l}\text { fistance } \\
\text { in }\end{array}$ & $\frac{\frac{8 M F M 4}{170 \mathrm{~cm}}}{\frac{1554}{1.5}}$ & $\begin{array}{l}\text { Coun } \\
\text { Loca } \\
\text { Pare } \\
\text { Vege } \\
\text { Hor. }\end{array}$ & $\begin{array}{l}\text { Hat } \\
\text { ion } \\
\text { tion } \\
\text { ef. }\end{array}$ & erial & 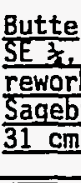 & $\frac{\text { NE } 3, \text { Sed }}{\text { ked loess }} \frac{\text { rush, win }}{\text { top, } 50}$ & over a & 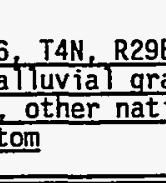 & $\frac{\mathrm{vel}}{\mathrm{ve} \text { spec }}$ & & \\
\hline $\begin{array}{c}\text { Samp. } \\
\text { No. }\end{array}$ & $\begin{array}{l}\text { Depth } \\
(\mathrm{cm})\end{array}$ & Horizon & Text. & Cons & ist. & Lime & roots & Pores & $\begin{array}{l}\text { Color } \\
\text { (wet) }\end{array}$ & Structure & Boundary & $\%$ rock \\
\hline 1 & $0-3$ & A. & sil & 10 & so po & e & lyff & & $10 Y R \quad 3 / 3.5$ & 70 & cs & \\
\hline 2 & $3-14$ & $B w$ & sil & so & ss os & es & 3vff, $2 m$ & & 10YR $3 / 3$ & Ifmsbk & gs & $\leq 10$ \\
\hline 3 & $14-43$ & Butk & sil & sh & ss os & es & $2 \mathrm{vff}, 1 \mathrm{~m}$ & & 10YR $3 / 4$ & 2 fmsbk & cs & \\
\hline 4 & $43-81$ & 2Bk & sil & $h$ & ss os & es & lvff & & 10YR $4 / 3$ & 2 fmsbk & & $\geq 60$ \\
\hline
\end{tabular}

Comments:

1. Intermound position

2. Trench floor below $63 \mathrm{~cm}$ is comprised of very hard cemented gravels with/orange tinted caliche

3. Basal gravels are poorly sorted, subrounded, $<1 \mathrm{~mm}$ thick caliche coats on bottoms - limestone.

4. Interstices filled with silt.

\begin{tabular}{|c|c|c|c|c|}
\hline $\begin{array}{c}\text { Samp. } \\
\text { No. }\end{array}$ & Depth & Horizon & $\mathrm{pH}$ & $\begin{array}{c}\mathrm{EC} \\
(\mathrm{mS} / \mathrm{cm})\end{array}$ \\
\hline \hline 1 & $0-3$ & $\mathrm{~A}$ & 7.6 & 1.050 \\
\hline 2 & $3-14$ & $B w$ & 8.3 & 0.28 \\
\hline 3 & $14-29$ & $B w k$ & 8.2 & 0.22 \\
\hline 4 & $29-43$ & $B$ kw & 8.4 & 0.21 \\
\hline 5 & $43-81$ & $2 B k$ & 8.3 & 0.31 \\
\hline
\end{tabular}

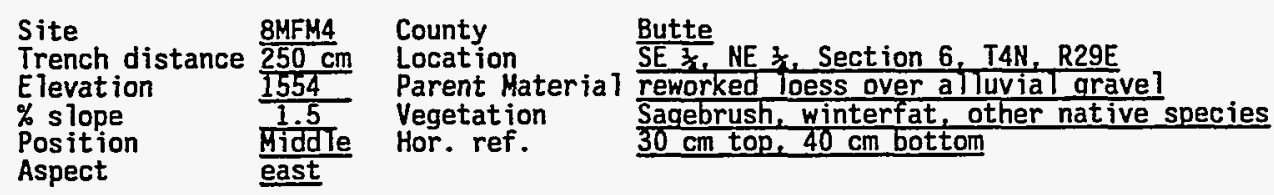

\begin{tabular}{|c|c|c|c|c|c|c|c|c|c|c|c|c|}
\hline $\begin{array}{c}\text { Samp. } \\
\text { No. }\end{array}$ & $\begin{array}{l}\text { Depth } \\
(\mathrm{cm})\end{array}$ & Horizon & Text. & $\frac{\text { Cons }}{d r y}$ & $\begin{array}{l}\text { sist. } \\
\text { wet }\end{array}$ & Lime & roots & Pores & $\begin{array}{l}\text { Color } \\
\text { (wet) }\end{array}$ & Structure & Boundary & $\%$ rock \\
\hline 1 & $0-12$ & $B w$ & sil & so & so no & $e$ & Ivff & & $10 Y R \quad 3 / 3,5$ & 10 & cs & \\
\hline 2 & $12-29$ & Bwk1 & sil & sh & ss os & es & 3vff, $2 m$ & & 10YR $3 / 3$ & $1 \mathrm{fmshk}$ & qs & $\leq 10$ \\
\hline 3 & $29-41$ & Buk? & sil & $h$ & ss ns & es & 2vff $1 \mathrm{~m}$ & & 10YR $3 / 4$ & $2 \mathrm{fmsbk}$ & CS & $>10$ \\
\hline 4 & $41-70$ & $2 B k$ & gravel & & ss os & es & Ivff & & $10 Y R \quad 4 / 3$ & $2 \mathrm{fmsbk}$ & & $>60$ \\
\hline
\end{tabular}

Comments:

1. This profile is the same as those at 28 and $170 \mathrm{~cm}$, however the $A$ horizon is missing, and the Bwk has been split into two units on the bas is of increased gravel content with depth. Gravels have caliche coats mainly on the bottom of clasts. Orientation of clasts with respect to flat sides is random.

2. At $260 \mathrm{~cm}$ the gravel content in the upper horizons increases to $20 \%$. Soil development remains consistent

3. From 220-240 the gravels of the $2 B k$ are disrupted possibly by bioturbation. Loose silt flows out of the interstices. From 240-320 the gravels are present but no longer held together by calcium carbonate. At $370 \mathrm{~cm}$, the bed is sharply truncated.

Site

Trench distance 8MFM

$\frac{350 \mathrm{~cm}}{1554}$

\% slope

Position

$350 \mathrm{~cm}$ Location

Butte

$\frac{1554}{15}$

1.5

Middle

SE NE 3, Section 6, T4N, R29E

Parent Material reworked loess over a luvial aravel

Vegetation Sagebrush, winterfat, other native species

Hor. ref. $34 \mathrm{~cm}$ top $48 \mathrm{~cm}$ bottom

\begin{tabular}{|c|c|c|c|c|c|c|c|c|c|c|c|c|}
\hline $\begin{array}{l}\text { Samp. } \\
\text { No. }\end{array}$ & $\begin{array}{c}\text { Depth } \\
(\mathrm{cm})\end{array}$ & Horizon & Text. & Cons & wet. & Lime & roots & Pores & $\begin{array}{l}\text { Color } \\
\text { (wet) }\end{array}$ & Structure & Boundary & $\%$ rock \\
\hline 1 & $0-3$ & $A$ & sil & 10 & so no & e & if & & $10 Y R \quad 3 / 2.5$ & 170 & CS & \\
\hline 2 & $3-22$ & $B H$ & sil & sh & ss os & es & if & & 10YR $4 / 3$ & Ifmsbk & as & 10 \\
\hline 3 & $22-49$ & Buk & sil & ysh & ss ps & es & if & $\operatorname{trf}$ & 10YR $4 / 3$ & 2 fmsbk & cs & \\
\hline 4 & $49-82$ & $2 B k$ & aravel & 10 & so ps & ev & $\operatorname{trf}$ & & 10YR $4 / 3.5$ & massive & & 50 \\
\hline
\end{tabular}

Comments:

1. Mound/intermound boundary position.

2. The $2 B K$ is disturbed. Silt fiows from between the clasts. 


\begin{tabular}{|c|c|c|c|c|c|c|c|c|c|c|c|c|}
\hline $\begin{array}{l}\text { Site } \\
\text { Trench } \\
\text { Elevati } \\
\% \text { s lope } \\
\text { Positio } \\
\text { Aspect }\end{array}$ & $\begin{array}{l}\text { distance } \\
\text { on } \\
\text { n }\end{array}$ & $\begin{array}{l}\frac{\text { 8MFM4 }}{480 \mathrm{~cm}} \\
\text { T.5 } \\
\text { Middle } \\
\text { east }\end{array}$ & $\begin{array}{l}\text { Coun } \\
\text { Loca } \\
\text { Pare } \\
\text { Vege } \\
\text { Hor. }\end{array}$ & $\begin{array}{l}y \\
\text { ion } \\
t \text { Mat } \\
\text { ation } \\
\text { ref. }\end{array}$ & ial & 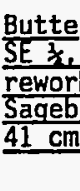 & $\frac{\text { Ne } \frac{1}{2}}{\frac{\text { Ked } \frac{10}{10}}{\text { rush, }}}$ & $\frac{\frac{\text { Secti }}{\text { ess ov }}}{\text { winter }}$ & $\begin{array}{l}\frac{\text { on } 6, \text { TAN, }}{\text { er alluvial }} \\
\text { fat. other } \\
\text { oottom }\end{array}$ & $\frac{\text { R29E }}{\frac{\text { gravel }}{\text { native spec }}}$ & ies & \\
\hline Samp. & Depth & Horizon & Text. & Cons & ist. & Lime & roots & Pores & Color & Structure & Boundary & $\%$ rock \\
\hline & & & & dry & wet & & & & & & & \\
\hline 1 & $0-10$ & A. & sil & 10 & so no & $e$ & lvff & & 10YR $4 / 2$ & 70 & & \\
\hline 2 & $10-32$ & Bw & sil & ysh & sons & es & 2vff & & 10YR $4 / 3$ & $1 \mathrm{fmsbk}$ & & \\
\hline 3 & $32-64$ & Buk & sil & sh & so ns & ey & lyff & & 10YR $4 / 3$ & $1 \mathrm{fmshk}$ & & \\
\hline 4 & $64-106$ & Bk1 & sil & 10 & so ps & $\mathrm{ev}$ & trf & & 10YR $4.5 / 3$ & 3 massive & & \\
\hline
\end{tabular}

Corments:

1. Mound position

2. Gravel is distributed evenly throughout; thin caliche coats on bottoms; no evident bedding.

3. Soil development is very weak.

\begin{tabular}{|c|c|c|c|c|}
\hline $\begin{array}{c}\text { Samp. } \\
\text { No. }\end{array}$ & Depth & Horizon & $\mathrm{pH}$ & $\begin{array}{c}\mathrm{EC} \\
(\mathrm{mS} / \mathrm{cm})\end{array}$ \\
\hline \hline 1 & $0-10$ & $\mathrm{~A}$ & 7.9 & 0.47 \\
\hline 2 & $10-32$ & $\mathrm{Bw}$ & 8.0 & 0.31 \\
\hline 3 & $32-64$ & $\mathrm{Bwk}$ & 8.1 & 0.33 \\
\hline 4 & $64-106$ & $\mathrm{Bkl}$ & 8.3 & 0.31 \\
\hline
\end{tabular}

Trench distance $\frac{8 M F \mathrm{~cm}}{580 \mathrm{~cm}}$ Location Butte

Elevation

\% slope

Position

Aspect

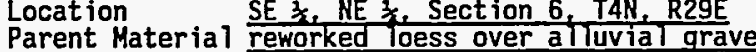

Vegetation Sagebrush, winterfat, other native species

Hor. ref. $\quad 45 \mathrm{~cm}$ top, $75 \mathrm{~cm}$ bottom

\begin{tabular}{|c|c|c|c|c|c|c|c|c|c|c|c|c|}
\hline $\begin{array}{c}\text { Samp. } \\
\text { Ho. }\end{array}$ & $\underset{\text { Depth }}{\text { (cm) }}$ & Horizon & Text. & Con & ist. & Lime & roots & Pores & $\begin{array}{l}\text { Color } \\
\text { (wet) }\end{array}$ & Structure & Boundary & $\%$ rock \\
\hline 1 & $0-3$ & A & sil & 10 & so no & eo & - & & 10YR 2/2 & 10 & cs & 5 \\
\hline 2 & $3-9$ & $A B$ & sil & vsh & so 00 & eo & $2 v f f$ & & 10YR $4 / 2$ & 70 & as & 5 \\
\hline 3 & $9-50$ & BW & sil & vsh & so oo & e & 2yffm & & 10YR $4 / 3$ & $1 \mathrm{fm}$ sbk & as & 15 \\
\hline 4 & $50-70$ & Bk & sil & sh & so_po & es & trf & trf & 10YR $4 / 3$ & 2 fmsbk & cs & 20 \\
\hline 5 & $70-120$ & $B C$ & sil & sh & so 00 & es & trf & trf & 10YR $5 / 3$ & $1 \mathrm{fmsbk}$ & & 20 \\
\hline
\end{tabular}

Comments:

1. Hound position

2. Bioturbated zone extends from $610-820 \mathrm{~cm}$. The section is comprised of massive silt and gravel,

parts have developed a 1 fmsbk structure. $A 10 \mathrm{~cm}$ high remnant of the 2 Bk extends from $725-745 \mathrm{~cm}$.

the remnant contains bedded gravel and calcium carbonate accumulation but is loose.

3. $20 \%$ gravels in the upper soil horizons; oriented at all angles with respect to caliche coats. Very

few gravels $>5 \mathrm{~cm}$ occur in the upper $45 \mathrm{~cm}$.

4. Fine roots are common throughout the bioturbated section.

5. A mammal nest is located at $830 \mathrm{~cm}$; filled with scat and vegetation

3. Soil development is very weak.

\begin{tabular}{|c|c|c|c|c|c|c|c|c|c|c|c|c|}
\hline $\begin{array}{l}\text { Site } \\
\text { Trench } \\
\text { Elevati } \\
\% \text { s lope } \\
\text { Positio } \\
\text { Aspect }\end{array}$ & $\begin{array}{l}\text { Jistance } \\
\text { on }\end{array}$ & 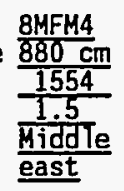 & $\begin{array}{l}\text { Count } \\
\text { Locat } \\
\text { Paren } \\
\text { Veget } \\
\text { Hor. }\end{array}$ & $\begin{array}{l}y \\
\text { ion } \\
t \text { Mat } \\
\text { ation }\end{array}$ & rial & 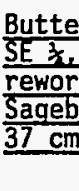 & $\frac{\text { ME }}{\text { ked }}$ & $\frac{\frac{\text { Sect } i}{\text { iess ov }}}{\frac{\text { winter }}{66 \mathrm{~cm}}}$ & $\frac{\frac{n}{6} 6_{\text {IT }} \text { T4N, }}{\text { at a luvia }}$ & $\frac{\frac{\text { R29E }}{\text { gravel }}}{\text { native spe }}$ & & \\
\hline $\begin{array}{c}\text { Samp. } \\
\text { Ho. }\end{array}$ & $\begin{array}{c}\text { Depth } \\
\text { (cm) }\end{array}$ & Horizon & Text. & $\frac{\text { Con }}{d r y}$ & ist. & Lime & roots & Pores & $\begin{array}{l}\text { Color } \\
\text { (wet) }\end{array}$ & Structure & Boundary & $\%$ ro \\
\hline 1 & $0-3$ & $A$ & $\overline{s i l}$ & 70 & so do & & - & & 10YR $3 / 3$ & $a r$ & cs & \\
\hline 2 & $3-35$ & $\mathrm{Bw}$ & sil & 10 & so no & e & $2 \mathrm{fm}^{\prime}$ & & 10YR $3 / 3$ & massive & cs & 20 \\
\hline 3 & $35-45$ & Bwk & sil & sh & so do & es & $\operatorname{trf}$ & & 10YR $4 / 3$ & 1vffsbk & $\mathrm{cW}$ & 20 \\
\hline 4 & $45-79$ & $2 \mathrm{Bk} 1$ & aravel & $h$ & & ev & $\operatorname{trf}$ & & & massive & cs & 50 \\
\hline 5 & $79-103$ & 2Bk2 & gravel & 10 & & es & $1 \mathrm{rf}$ & & & massive & & 50 \\
\hline
\end{tabular}


Comments:

1. Hound position $\quad$ This soil profile extends to the right end of the trench which ends at $1400 \mathrm{~cm}$. The upper soit

horizons. Bw Bwk, are disturbed, gravels are oriented at all angles. These horizons extend

laterally to the right end of the trench, but become indistinct, and the bioturbation gradually

ends. As the soil thins toward the right side of the trench, the boundary between the BW and Bk1 is wavy and indistinct.

3. The A horizon is discontinuous across the entire mound.

4. The basal gravel units contain $\approx 10 \%$ coarse sand which is orange red coated (10YR 5/6). The caliche on the lower gravels gives a very white color in-place.

\begin{tabular}{|c|c|c|c|c|}
\hline $\begin{array}{c}\text { Samp. } \\
\text { No. }\end{array}$ & Depth & Horizon & $\mathrm{pH}$ & $\begin{array}{c}\mathrm{EC} \\
(\mathrm{mS} / \mathrm{cm})\end{array}$ \\
\hline \hline 1 & $0-35$ & $\mathrm{~A}$ & 8.0 & 0.34 \\
\hline 2 & $35-45$ & $\mathrm{BW}$ & 8.0 & 0.39 \\
\hline 3 & $45-79$ & $2 \mathrm{Bk} 1$ & 7.9 & 0.73 \\
\hline 4 & $79-103$ & $2 \mathrm{BkK} 2$ & 8.4 & 0.81 \\
\hline
\end{tabular}

\begin{tabular}{|c|c|c|c|c|c|c|c|c|c|c|c|c|}
\hline $\begin{array}{l}\text { Site } \\
\text { Trench } \\
\text { Elevat } \\
\% \text { slop } \\
\text { Positi } \\
\text { Aspect }\end{array}$ & Jistance & $\begin{array}{l}\frac{\text { 8MFM4 }}{1270 \mathrm{~cm}} \\
\frac{1554}{1.5} \\
\frac{\text { Middle }}{\text { east }}\end{array}$ & $\begin{array}{l}\text { Count } \\
\text { Locat } \\
\text { Parer } \\
\text { Veget } \\
\text { Hor. }\end{array}$ & $\begin{array}{l}y \\
\text { ion } \\
t \text { Mat } \\
\text { ation } \\
\text { ref. }\end{array}$ & ial & $\frac{\frac{\text { Butte }}{\text { SE } \frac{1}{k_{1}}}}{\frac{\text { rewor }}{\text { Sageb }}}$ & $\frac{\text { ME } z_{\text {. }}}{\frac{\text { ked } 10}{\text { rush, }}}$ & $\frac{\text { Sectic }}{\frac{\text { Ss ove }}{\text { intert }}}$ & $\frac{\frac{6}{\text { alluvia }}}{\frac{\text { ThN, }}{\text { other }}}$ & $\begin{array}{l}\text { R29E } \\
\frac{\text { gravel }}{\text { native spec }}\end{array}$ & ies & \\
\hline $\begin{array}{l}\text { Samp. } \\
\text { No. }\end{array}$ & $\begin{array}{l}\text { Depth } \\
\text { (cm) }\end{array}$ & Horizon & Text. & $\frac{\text { Con }}{d r y}$ & $\begin{array}{l}\text { ist. } \\
\text { wet }\end{array}$ & Lime & roots & Pores & $\begin{array}{l}\text { Color } \\
\text { (wet) }\end{array}$ & Structure & Boundary & $\%$ rock \\
\hline 1 & $0-3$ & A & sil & & & & & & & ar & & \\
\hline 2 & $3-20$ & $B$ & sil & 10 & so no & & & & & $1 \mathrm{mcsbk}$ & & 10 \\
\hline 3 & $20-42$ & Buk & sil & sh & so os & & & & & $2 \mathrm{fmsbk}$ & & 50 \\
\hline 4 & $42-63$ & $2 B k i$ & aravel & $h$ & & & $f$ & & & massive & & \\
\hline
\end{tabular}

\section{Comments:}

1. Mound position

2. The $B w$ and Bwk grade into each other and are difficult to differentiate.

3. Strongly developed white color of the basal gravels is greatly decreased by $1100 \mathrm{~cm}$. Gravels are not as strongly cemented at this location.

\begin{tabular}{|c|c|c|c|c|}
\hline $\begin{array}{c}\text { Samp. } \\
\text { No. }\end{array}$ & Depth & Hor izon & $\mathrm{pH}$ & $\begin{array}{c}\mathrm{EC} \\
(\mathrm{mS} / \mathrm{cm})\end{array}$ \\
\hline \hline 1 & $0-3$ & $\mathrm{~A}$ & 7.7 & 0.51 \\
\hline 2 & $3-20$ & $\mathrm{Bw}$ & 8.1 & 0.47 \\
\hline 3 & $20-42$ & $\mathrm{Bwk}$ & 8.2 & 0.26 \\
\hline 4 & $42-63$ & $2 \mathrm{Bkl}$ & 8.0 & 0.21 \\
\hline
\end{tabular}

\begin{tabular}{|c|c|c|c|c|c|c|c|c|c|c|c|c|}
\hline \multicolumn{2}{|c|}{$\begin{array}{l}\text { Site } \\
\text { Trench distance } \\
\text { Elevation } \\
\text { \% s lope } \\
\text { Position } \\
\text { Aspect }\end{array}$} & $\begin{array}{l}\frac{\text { BLRM2 }}{0 \mathrm{~cm}} \\
\frac{1527}{0}\end{array}$ & \multicolumn{3}{|c|}{$\begin{array}{l}\text { County } \\
\text { Location } \\
\text { Parent Material } \\
\text { Vegetation } \\
\text { Hor. ref. }\end{array}$} & \multicolumn{4}{|c|}{$\begin{array}{l}\frac{\text { Butte }}{N W \frac{3}{3} \text { Section } 5, \text { T2N, R29E }} \\
\text { flood overbank deposits } \\
40 \mathrm{~cm} \text { top, } 57 \mathrm{~cm} \text { bottom }\end{array}$} & & & \\
\hline $\begin{array}{c}\text { Samp. } \\
\text { No. }\end{array}$ & $\begin{array}{c}\text { Depth } \\
\text { (cm) }\end{array}$ & Horizon & Text. & $\frac{\text { Con }}{\text { dry }}$ & ist. & Lime & roots & Pores & $\begin{array}{l}\text { Color } \\
\text { (wet) }\end{array}$ & Structure & Boundary & $\%$ rock \\
\hline 1 & $0-6$ & & sand & 10 & & - & $3 \mathrm{fm}$ & & 10YR $3 / 4$ & & cs & 5 \\
\hline 2 & $6-14$ & & ls & sh & so Do & - & $2 f$ & & 10YR $3 / 4$ & $1 \mathrm{mcsbk}$ & cs & 5 \\
\hline 3 & $14-27$ & & ls & sh & so 00 & e & If & & $10 Y R \quad 3 / 4$ & 2mcspbk & cs & 5 \\
\hline 4 & $27-43$ & & ls & $h$ & ss no & es & tf & tf & 10YR $4 / 3$ & $2 m c s b k$ & cs & \\
\hline 5 & $43-63$ & & s] & yh & ss os & es & tf & tf & 10YR $5 / 2$ & $3 m s b k$ & cs & \\
\hline 6 & $63-97$ & & arave & & & & & & & & & \\
\hline
\end{tabular}

Comments:

1. Intermound position

2. Gravels in the soil matrix are evenly distributed, at all angles but mainly flat. Caliche rinds on all sides. 


\begin{tabular}{|c|c|c|c|c|c|c|c|c|c|c|c|c|}
\hline $\begin{array}{l}\text { Site } \\
\text { Trench } \\
\text { Elevati } \\
\% \text { slope } \\
\text { Positio } \\
\text { Aspect }\end{array}$ & $\begin{array}{l}\text { distance } \\
\text { on } \\
\text { n }\end{array}$ & $\frac{\frac{\text { BLRM2 }}{280 \mathrm{~cm}}}{\frac{\frac{1527}{0}}{\frac{1527}{2}}}$ & $\begin{array}{l}\text { Count } \\
\text { Locat } \\
\text { Parer } \\
\text { Veget } \\
\text { Hor. }\end{array}$ & $\begin{array}{l}y \\
\text { ion } \\
t \text { Mat } \\
\text { tion } \\
\text { ref. }\end{array}$ & ia 1 & 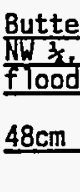 & $\begin{array}{l}\frac{\text { Sectic }}{\text { overb }} \\
\text { top, } 8\end{array}$ & $\frac{2 \mathrm{on} 5}{\mathrm{ank} \text { de }}$ & $\frac{2 N, R 29 E}{\text { tom }}$ & & & \\
\hline $\begin{array}{c}\text { Samp. } \\
\text { No. }\end{array}$ & $\begin{array}{c}\text { Depth } \\
\text { (cm) }\end{array}$ & Horizon & Text. & $\begin{array}{l}\text { Cons } \\
\text { dry }\end{array}$ & ist. & Lime & roots & Pores & $\begin{array}{l}\text { Color } \\
\text { (wet) }\end{array}$ & Structure & Boundary & $\%$ rock \\
\hline 1 & $0-4$ & $A$ & sand & 10 & & - & & & & loose & cs & 10 \\
\hline 2 & $4-13$ & $A B$ & ls & 10 & so vo & - & $2 f$ & & & 1 masbk & cs & 10 \\
\hline 3 & $13-32$ & $2 B \mathrm{~W}$ & ls & sh & so 00 & - & lvff & & & $1 \mathrm{mcsbk}$ & qs & 5 \\
\hline 4 & $32-50$ & $2 B \mathrm{k} 1$ & 1s & h & so no & e & tyff & & & 2mcsbk & qS & 10 \\
\hline 5 & $50-110$ & $2 \mathrm{Bk}$ ? & Is & $h$ & so no & es & $t$ & & 10YR $5 / 2$ & massive & cs & 5 \\
\hline 6 & $110-130$ & $3 C$ & gravel & & & & & & & & & \\
\hline
\end{tabular}

Corments:

1. Horizons 2 and 3 appear bedded.

\begin{tabular}{||c|c|c|c|c|}
\hline $\begin{array}{c}\text { Samp. } \\
\text { No. }\end{array}$ & Depth & Horizon & $\mathrm{pH}$ & $\begin{array}{c}\mathrm{EC} \\
(\mathrm{mS} / \mathrm{cm})\end{array}$ \\
\hline \hline 1 & $0-4$ & $\mathrm{~A}$ & 7.5 & 0.44 \\
\hline 2 & $4-13$ & $\mathrm{AB}$ & 7.7 & 0.30 \\
\hline 3 & $13-32$ & $2 \mathrm{Bw}$ & 8.0 & 0.42 \\
\hline 4 & $32-50$ & $2 \mathrm{Bk} 1$ & 8.2 & 0.19 \\
\hline 5 & $50-110$ & $28 \mathrm{k} 2$ & 8.4 & 0.26 \\
\hline 6 & $110-130$ & $3 \mathrm{C}$ & & \\
\hline
\end{tabular}

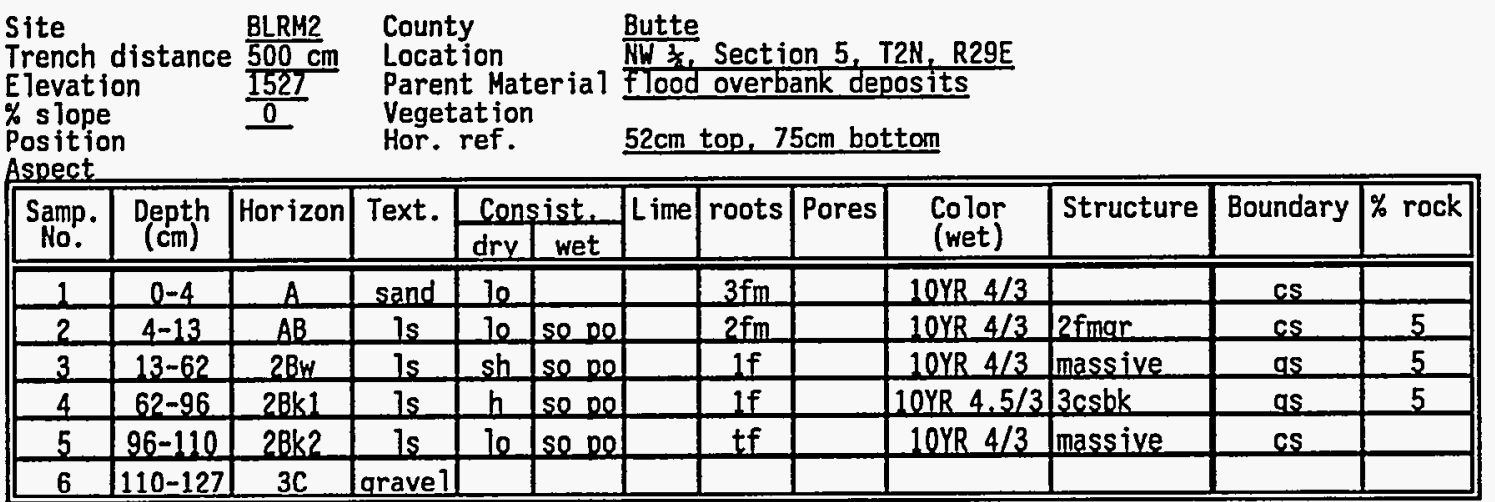

Comments:

1. Position is within the mound near the left side of the disturbed zone.

\begin{tabular}{|c|c|c|c|c|c|c|c|c|c|c|c|c|}
\hline $\begin{array}{l}\text { Site } \\
\text { Trench } \\
\text { Elevati } \\
\text { \% slope } \\
\text { Positio } \\
\text { Aspect }\end{array}$ & $\begin{array}{l}\text { distance } \\
\text { on } \\
n\end{array}$ & $\frac{\frac{B L R H 2}{735 \mathrm{~cm}}}{\frac{1527}{0}}$ & $\begin{array}{l}\text { Coun } \\
\text { Loca } \\
\text { Pare } \\
\text { Vege } \\
\text { Hor. }\end{array}$ & $\begin{array}{l}y \\
\text { ion } \\
t \text { Mat } \\
\text { ation } \\
\text { ref. }\end{array}$ & ia 1 & $\begin{array}{l}\frac{\text { Butte }}{\frac{N 1}{1} \frac{1}{2}} \\
\frac{1000}{66 \mathrm{~cm}}\end{array}$ & $\begin{array}{l}\text { Sect i } \\
\text { overb } \\
\text { top, b }\end{array}$ & $\frac{\text { on } 5 .}{\text { ank der }}$ & $\frac{\text { N, R29E }}{\text { asts }}$ & & & \\
\hline $\begin{array}{l}\text { Samp. } \\
\text { No. }\end{array}$ & $\begin{array}{l}\text { Depth } \\
\text { (cm) }\end{array}$ & Horizon & Text. & $\begin{array}{l}\text { Cons } \\
\text { dry }\end{array}$ & $\begin{array}{l}\text { ist. } \\
\text { wet }\end{array}$ & Lime & roots & Pores & $\begin{array}{l}\text { Color } \\
\text { (wet) }\end{array}$ & Structure & Boundary & $\%$ rock \\
\hline 1 & $0-11$ & A & sand & 10 & & - & $2 \mathrm{fm}$ & & & 10 & cs & $<5$ \\
\hline 2 & $11-44$ & $B w$ & Is & lo & se 00 & $e$ & $2 \mathrm{fm}$ & & & 1csblk & qs & 10 \\
\hline 3 & $44-106$ & Buk & Is & 10 & & es & If & & 10YR $3,5 / 3$ & massive & ci & 20 \\
\hline 4 & $106-118$ & $2 B k 2$ & ls & $h$ & & es & - & & & 2 fmsbk & cs & 10 \\
\hline 5 & $118-126$ & $3 C$ & & & & & & & & & & \\
\hline
\end{tabular}

Comments:

1. Position is within the disturbed zone. Recent, (loose, high organic content) krotovina are within

the Bk2 horizon, which is in remnants only.

2. Gravel content is higher in the mixed soils. 


\begin{tabular}{|c|c|c|c|c|}
\hline $\begin{array}{c}\text { Samp. } \\
\text { No. }\end{array}$ & Depth & Horizon & $\mathrm{pH}$ & $\begin{array}{c}\mathrm{EC} \\
(\mathrm{mS} / \mathrm{cm})\end{array}$ \\
\hline \hline 1 & $0-11$ & $\mathrm{~A}$ & 2.5 & \\
\hline 2 & $106-118$ & $2 \mathrm{Bk2}$ & 8.6 & 1.42 \\
\hline
\end{tabular}

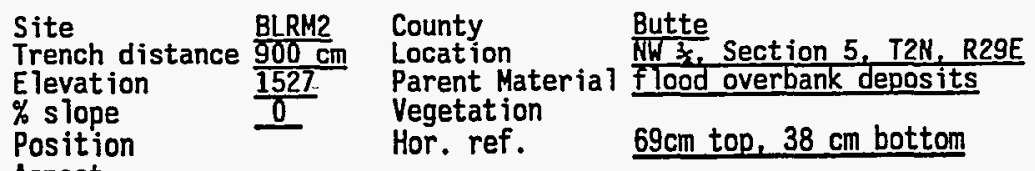

Aspect

\begin{tabular}{|c|c|c|c|c|c|c|c|c|c|c|c|c|}
\hline $\begin{array}{l}\text { Samp. } \\
\text { No. }\end{array}$ & $\begin{array}{c}\text { Depth } \\
\text { (cm) }\end{array}$ & Horizon & Text. & Con & wet & Lime & roots & Pores & $\begin{array}{l}\text { Color } \\
\text { (wet) }\end{array}$ & Structure & Boundary & $\%$ rock \\
\hline 1 & $0-8$ & A & sand & 10 & & & $3 \mathrm{fm}$ & & & 10 & & $<5$ \\
\hline 2 & $8-24$ & Bw & & 10 & & & $3 \mathrm{fm}$ & & & 2mcsblk & & 5 \\
\hline 3 & $24-62$ & Buk & ls & sh & & es & if & & & 1 masbk & & 20 \\
\hline 4 & $62-77$ & $2 \mathrm{Bk} l$ & s] & $h$ & SS Ds & es & tr & & $10 Y R \quad 5 / 3$ & 3 mesbk & - & 10 \\
\hline 5 & $77-94$ & $2 B k ?$ & & 10 & & & tr & & & & & \\
\hline 6 & 94-107 & $3 B k 3$ & & $h$ & & & tr & & $10 Y R \quad 5 / 3$ & & & 50 \\
\hline 7 & $107-118$ & $3 C$ & gravel & & & & & & & & & \\
\hline
\end{tabular}

Comments:

1. Mound position at edge of disturbed/undisturbed zone.

2. The Bw and Bwk horizons are weakly formed in the bioturbated soils. Weak pedogenesis likely indicates old age of disturbance.

3. The 2BKI is whiter than the correlative unit on the opposite side of the disturbed zone.

4. A krotovina extends laterally in horizon 5 from $875-970 \mathrm{~cm}$.

5. The 2BK1 and 2BK2 horizons are remnants.

6. The $3 \mathrm{Bk} 3$ is an accumulation of $\mathrm{CaCO}^{3}$ at the top of the bedded gravels.

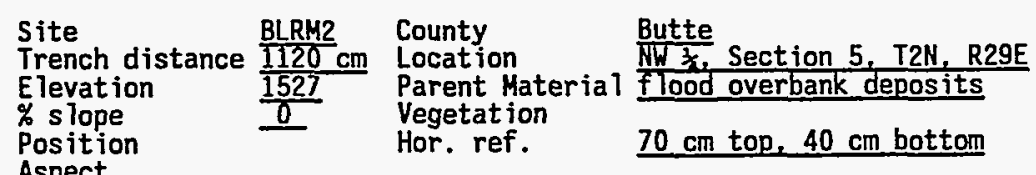

\begin{tabular}{|c|c|c|c|c|c|c|c|c|c|c|c|c|}
\hline Samp. & Depth & Horizon & Text. & Cons & ist. & Lime & roots & Pores & Color & Structure & Boundary & $\%$ rock \\
\hline No. & $(\mathrm{cm})$ & & & dry & wet & & & & (wet) & & & \\
\hline 1 & $0-4$ & A & sand & 10 & & & $2 \mathrm{fm}$ & & & 10 & & 5 \\
\hline 2 & $4-15$ & $A B$ & ls & 10 & so 00 & $e$ & $1 \mathrm{~m}$ & & & Imsbk & & $5-10$ \\
\hline 3 & $15-36$ & $2 \mathrm{BW}$ & 1s & 10 & so $n 0$ & es & tr & & & mass & & $5-10$ \\
\hline 4 & $36-50$ & $2 \mathrm{Bk} 1$ & Is & sh & & es & tr & & & 2mcsblk & & 5 \\
\hline 5 & $50-70$ & $38 \mathrm{k} 2$ & s] & $h$ & & es & tr & & & 3 mesblk & & 50 \\
\hline 6 & $70-93$ & $3 B \mathrm{k} 2$ & aravel & h & & & & & & mass & & \\
\hline 7 & $93-110$ & $3 \mathrm{C}$ & gravel & & & & & & & & & \\
\hline
\end{tabular}

Comments:

1. Mound position; undisturbed profile to the right of the central bioturbation section.

2. The $3 \mathrm{Bk2}, 3 \mathrm{BK} 3$, and $3 \mathrm{C}$ horizons are formed in bedded gravels.

3. The $3 B K 2$ and $3 B k 3$ horizons are separated by a thin sand lens.

\begin{tabular}{|c|c|c|c|c|}
\hline $\begin{array}{c}\text { Samp. } \\
\text { No. }\end{array}$ & Depth & Horizon & pH & $\begin{array}{c}\text { EC } \\
(\mathrm{mS} / \mathrm{cm})\end{array}$ \\
\hline \hline 1 & $0-4$ & $\mathrm{~A}$ & 7.2 & 7.60 \\
\hline 2 & $4-15$ & $\mathrm{AB}$ & 7.8 & 3.07 \\
\hline 3 & $15-36$ & $2 \mathrm{BH}$ & 8.3 & 2.65 \\
\hline 4 & $36-50$ & $2 \mathrm{Bk} 1$ & 8.2 & 2.86 \\
\hline 5 & $50-70$ & $3 \mathrm{Bk} 2$ & 8.2 & 4.24 \\
\hline 6 & $70-93$ & $3 \mathrm{Bk} 3$ & 8.2 & 3.80 \\
\hline
\end{tabular}




\begin{tabular}{|c|c|c|c|c|c|c|c|c|c|c|c|c|}
\hline \multicolumn{2}{|c|}{$\begin{array}{l}\text { Site } \\
\text { Trench distance } \\
\text { Elevation } \\
\text { \% slope } \\
\text { Position } \\
\text { aspect }\end{array}$} & $\frac{\text { BLRM4 }}{\frac{40 \mathrm{~cm}}{1518}}$ & \multicolumn{3}{|c|}{$\begin{array}{l}\text { County } \\
\text { Location } \\
\text { Parent Material } \\
\text { Vegetation } \\
\text { Hor. ref. }\end{array}$} & \multicolumn{7}{|c|}{$\begin{array}{l}\frac{\text { Butte }}{\text { NW3, }} \\
\text { Flood deposits } \\
\text { Artemisia Tridentata, false qlobe mallow, Ha logeton }\end{array}$} \\
\hline \multirow{2}{*}{$\begin{array}{l}\text { Samp. } \\
\text { No. }\end{array}$} & \multirow{2}{*}{$\begin{array}{c}\text { Depth } \\
(\mathrm{cm})\end{array}$} & \multirow[t]{2}{*}{ Horizon } & \multirow[t]{2}{*}{ Text. } & \multicolumn{2}{|c|}{ Consist. } & \multirow[t]{2}{*}{ Lime } & \multirow[t]{2}{*}{ roots } & \multirow[t]{2}{*}{ Pores } & \multirow{2}{*}{$\begin{array}{l}\text { Color } \\
\text { (wet) }\end{array}$} & \multirow[t]{2}{*}{ Structure } & \multirow[t]{2}{*}{ Boundary } & \multirow[t]{2}{*}{$\%$ rock } \\
\hline & & & & dry & Het & & & & & & & \\
\hline 1 & $0-23$ & $A$ & $7 \mathrm{~s}$ & 10 & se no & eo & $1 \mathrm{fm}$ & - & 10YR3/2 & $1 \mathrm{sbk} / 3 \mathrm{mar}$ & cs. & 35 \\
\hline 2 & $23-?$ & $2 C$ & aravel & & & & & & & & & \\
\hline
\end{tabular}

Comments:

1. Intermound position

2. Horizon 2 is comprised of bedded gravels and matrix sands.

3. Gravels have caliche coats $0-1 \mathrm{~mm}$ thick, on bottom of clasts.

4. Ground surface is gravel armored in intermound area, less dense on mound.

5. Parent material is alluvial gravel, overlain by flood overbank deposits.

\begin{tabular}{|c|c|c|c|c|c|c|c|c|c|c|c|c|}
\hline $\begin{array}{l}\text { Site } \\
\text { Trench } \\
\text { Elevat } \\
\text { \% slope } \\
\text { Positic } \\
\text { aspect }\end{array}$ & Iistance & $\frac{\frac{B L R H 4}{85 \mathrm{~cm}}}{\frac{1518}{0}}$ & $\begin{array}{l}\text { Count } \\
\text { Locat } \\
\text { Paren } \\
\text { Veget } \\
\text { Hor. }\end{array}$ & $\begin{array}{l}\text { ion } \\
t \text { Mat } \\
\text { ation } \\
\text { ref. }\end{array}$ & erial & $\frac{\frac{\text { Butt }}{\frac{163}{6}}}{\frac{\text { Flood }}{\text { Artem }}} \frac{\text { mallo }}{\frac{23 \mathrm{~cm}}{23}}$ & $\frac{\frac{e}{W_{3},} \text { s }}{\text { depos }}$ & $\frac{\text { ection }}{\frac{\text { its }}{\text { rident }}} \frac{\text { geton }}{\frac{\text { cm do }}{2}}$ & 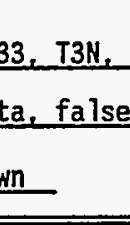 & lobe & & \\
\hline $\begin{array}{l}\text { Samp. } \\
\text { No. }\end{array}$ & $\begin{array}{c}\text { Depth } \\
(\mathrm{cm})\end{array}$ & Horizon & Text. & $\begin{array}{l}\text { Con } \\
\text { dry }\end{array}$ & $\begin{array}{l}\text { ist. } \\
\text { wet }\end{array}$ & lime & roots & Pores & $\begin{array}{l}\text { Color } \\
\text { (wet) }\end{array}$ & Structure & Boundary & $\%$ rock \\
\hline 1 & $0-12$ & A & 1s & 10 & so po & eo & $1 \mathrm{fm}$ & - & 10YR3/2 & $1 \mathrm{shk} / 3 \mathrm{mar}$ & cs. & 35 \\
\hline 2 & $12-25$ & $B W$ & s] & sh & so po & eo & $1 \mathrm{fm}$ & - & 10YRZ/3 & massive & ars & 20 \\
\hline 3 & $25-80$ & C & gravel & & & & & & & & & \\
\hline
\end{tabular}

Comments:

1. Intermound position.

2. Horizon 3 is bedded gravels, lightly cemented from $46-51 \mathrm{~cm}$. Distinct beds with different clast sizes are evident.

\begin{tabular}{|c|c|c|c|c|c|c|c|c|c|c|c|c|}
\hline $\begin{array}{l}\text { Site } \\
\text { Trench } \\
\text { Elevat } \\
\% \text { s lop } \\
\text { Positi } \\
\text { aspect }\end{array}$ & $\begin{array}{l}\text { distance } \\
\text { on }\end{array}$ & $\frac{\frac{\text { BLRH4 }}{105 \mathrm{~cm}}}{\frac{1518}{0}}$ & $\begin{array}{l}\text { Coun } \\
\text { Loca } \\
\text { Pare } \\
\text { Vege } \\
\text { Hor. }\end{array}$ & $\begin{array}{l}\text { ion } \\
\text { Mat } \\
\text { tior } \\
\text { ef. }\end{array}$ & rial? & $\frac{\frac{\text { Butt }}{\frac{14 \sqrt{3}}{N_{1}}}}{\frac{\text { Flood }}{\text { Artem }}}$ & $\frac{\frac{e}{N_{i x}, S}}{\text { depos }}$ & $\frac{\text { ection }}{\text { its }} \frac{\text { rident }}{0 \mathrm{~cm} \mathrm{dd}}$ & $\begin{array}{l}3, \mathrm{~T} 3 \mathrm{~N} \\
\mathrm{a}, \mathrm{fals} \\
\mathrm{n}\end{array}$ & $\begin{array}{l}29 \mathrm{E} \\
\text { qlobe ma } 110\end{array}$ & $N$, Ha logeto & \\
\hline $\begin{array}{l}\text { Samp. } \\
\text { No. }\end{array}$ & $\begin{array}{c}\text { Depth } \\
(\mathrm{cm})\end{array}$ & Horizon & Text. & & & Lime & roots & Pores & $\begin{array}{l}\text { Color } \\
\text { (wet) }\end{array}$ & Structure & Boundary & $\%$ rock \\
\hline 1 & $0-6$ & A1 & sand & 10 & So $\mathrm{Dol}$ & & $1 \mathrm{fm}$ & & 10YR3/2 & loose & CS & \\
\hline 2 & $6-15$ & $A 2$ & ls & 10 & so 00 & eo & $1 \mathrm{fm}$ & & 10YR3/2 & $1 \mathrm{sbk} / 3 \mathrm{mar}$ & cs & 35 \\
\hline 3 & $15-30$ & Bw & s] & sh & so 00 & eo & $1 \mathrm{fm}$ & & 10YR7/3 & massive & $\mathrm{cW}$ & 20 \\
\hline 4 & $30-68$ & C & gravel & & & & & & & & & \\
\hline
\end{tabular}

Corments :

1. Mound/intermound boundary.

2. Horizon 4 is bedded gravels with interstitial sand. The contact between the gravels and above soil

3. is clear and irregular to the point where the krotovina mask the boundary.

3. Gravel within the upper soils have no $\mathrm{CaCO}^{3}$ coats.

4. Position is exactly at the mound/intermound interface on the left side of the trench.

5. Al is a thin layer of eolian sand. 


\begin{tabular}{|c|c|c|c|c|c|c|c|c|c|c|c|c|}
\hline $\begin{array}{l}\text { Site } \\
\text { Trench } \\
\text { Elevat } \\
\% \text { slope } \\
\text { Posit ic } \\
\text { aspect }\end{array}$ & $\begin{array}{l}\text { distance } \\
\text { on } \\
\mathrm{n}_{0}\end{array}$ & $\frac{\frac{\text { BLRM4 }}{183 \mathrm{~cm}}}{\underline{1518}}$ & $\begin{array}{l}\text { Count } \\
\text { Locat } \\
\text { Paren } \\
\text { Veget } \\
\text { Hor. }\end{array}$ & $\begin{array}{l}\text { ion } \\
\text { Mat } \\
\text { ation } \\
\text { ref. }\end{array}$ & erial & $\frac{\frac{\text { Butt }}{\text { NWhte }}}{\frac{\text { Flood }}{\text { Flood }}}$ & $\frac{\frac{e}{12}, s}{\text { depos }}$ & $\frac{\text { ection }}{\frac{\text { its }}{\text { ridenta }}}$ & $\begin{array}{l}\text { 33, T3N, } \\
\frac{\mathrm{ta}, \mathrm{fa} \text { is }}{\mathrm{n}}\end{array}$ & $\begin{array}{l}\text { 229E } \\
\text { globe mallo }\end{array}$ & $4, \mathrm{Ha}$ logeto & \\
\hline Samp. & Depth & Horizon & Text. & Cons & ist. & Lime & roots & Pores & Color & Structure & Boundary & $\%$ rock \\
\hline & & & & $\square$ & & & & & & & & \\
\hline 1 & $0-10$ & $A$ & ls & 10 & so 0 & - & $1 \mathrm{fm}$ & & & 10/trmar & cs & 25 \\
\hline 2 & $10-32$ & $2 \mathrm{Bw}$ & is & so & & - & $2 \mathrm{fm}$ & $1 \mathrm{~m}$ & & $\operatorname{massive/1}_{\mathrm{sbk}}$ & grs & 25 \\
\hline 3 & $32-41$ & 2Bk1 & st & sh & ss $s p$ & - & trf & Im & & $\operatorname{massive/1~}_{\text {sbk }}$ & grs & 10 \\
\hline 4 & $41-56$ & $2 \mathrm{Bk} 2$ & $\operatorname{csl}$ & sh & ss $s p$ & es & $\operatorname{trf}$ & tf & & $\operatorname{massive/3}_{\text {sbk }}$ & cir & 25 \\
\hline 5 & $56-121$ & $3 C$ & gravel & & & - & trf & & & & & \\
\hline
\end{tabular}

\section{Comments:}

1. Mound position

2. Bedded grave is as previously described. There is a lens of large clasts up to $15 \mathrm{~cm}$, along the bottom of the trench.

Site BLRM4 County Butte

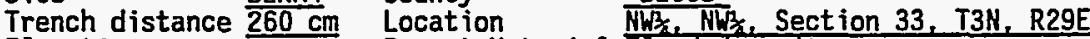

Elevation Parent Material Flood deposits

$\%$ slope $\quad 0 \quad$ Vegetation Artemisia Tridentata, false globe mallow, Ha logeton

Position Hor. ref. $\quad \frac{0}{43 \mathrm{~cm} \mathrm{Up}, 73 \mathrm{~cm} \text { down }}$

aspect

\begin{tabular}{|c|c|c|c|c|c|c|c|c|c|c|c|c|}
\hline $\begin{array}{l}\text { Samp. } \\
\text { No. }\end{array}$ & $\begin{array}{c}\text { Depth } \\
\text { (cm) }\end{array}$ & Horizon & Text. & $\frac{\text { Con }}{d r y}$ & sist. & Lime & roots & Pores & $\begin{array}{l}\text { Color } \\
\text { (wet) }\end{array}$ & Structure & Boundary & $\%$ rock \\
\hline 1 & $0-8$ & A & 1s & 10 & so_no & $=$ & $1 \mathrm{fm}$ & & & massive & cs & 15 \\
\hline 2 & $8-36$ & $2 B w$ & ls & so & so Do & - & $2 \mathrm{fm}$ & & $10 Y R 3 / 3$ & lesbk & ars & 15 \\
\hline 3 & $36-54$ & $2 B k 1$ & si & sh & ss $\mathrm{sp}$ & $e$ & $1 m$ & trf & 10YR4/2 & $\begin{array}{l}\text { mass ive } / 3 \\
\text { mcsbk }\end{array}$ & grs & 10 \\
\hline 4 & $54-76$ & $2 B k 2$ & $\operatorname{cs1}$ & $\bar{h}$ & , & $\overline{\text { es }}$ & trfm & & & $\begin{array}{l}\text { massive/3 } \\
\text { fmsbk }\end{array}$ & CW & 25 \\
\hline 5 & $76-116$ & $3 C$ & & & & & trm & & & & & \\
\hline
\end{tabular}

Comments:

1. Mound position

Site BLRH4

Trench distance $370 \mathrm{~cm}$

Elevation

s lope 0

Position

aspect

\begin{tabular}{|c|c|c|c|c|c|c|c|c|c|c|c|c|}
\hline Samp. & Depth & Horizon & Text. & Con & ist. & Lime & roots & Pores & Color & Structure & Boundary & $\%$ rock \\
\hline & & & & & & & & & & & & \\
\hline 1 & $0-6$ & A & ls & le & so no & - & $2 \mathrm{fm}$ & & 10YR3/2 & 10 & CS & \\
\hline 2 & $6-54$ & $2 B W$ & $7 s$ & sh & so sp & - & $2 \mathrm{fmc}$ & & 10YR3/4 & mass/2mcs & CW & 15 \\
\hline 3 & $54-85$ & $2 \mathrm{Bk} 1$ & s] & $h$ & ss so & es & $\operatorname{trf}$ & & 10YR3/3 & 3 fmsbl & $\mathrm{CW}$ & 10 \\
\hline 4 & $85-120$ & $3 C$ & gravel & & & - & & & & & & \\
\hline
\end{tabular}

Conments:

1. Mound position

2. Horizon 4 is bedded gravel.

2. Krotovina from $340-370 \mathrm{~cm}, 20 \mathrm{~cm}$ high; starts at base of horizon 3 , extends down into the gravels.

Filled with gravel and sand. Roots in krotovina: $2 \mathrm{fm}$.

\begin{tabular}{|c|c|c|c|c|c|c|}
\hline $\begin{array}{c}\text { Samp. } \\
\text { No. }\end{array}$ & $\begin{array}{c}\text { Depth } \\
(\mathrm{cm})\end{array}$ & Horizon & $\begin{array}{c}\text { sat } \% \\
\text { water }\end{array}$ & $\mathrm{pH}$ & $\begin{array}{c}\mathrm{EC} \\
(\mathrm{mS} / \mathrm{cm})\end{array}$ & $\begin{array}{c}\mathrm{CaC03} \\
\%\end{array}$ \\
\hline 1 & $0-6$ & $\mathrm{~A}$ & 48.1 & 5.9 & 1.73 & 0.6 \\
\hline 2 & $6-54$ & $28 \mathrm{w}$ & 33.6 & 7.8 & 1.3 & 0.9 \\
\hline 3 & $54-85$ & $2 \mathrm{Bk} 1$ & $\% 36.0$ & 8.4 & 0.41 & 14.8 \\
\hline
\end{tabular}




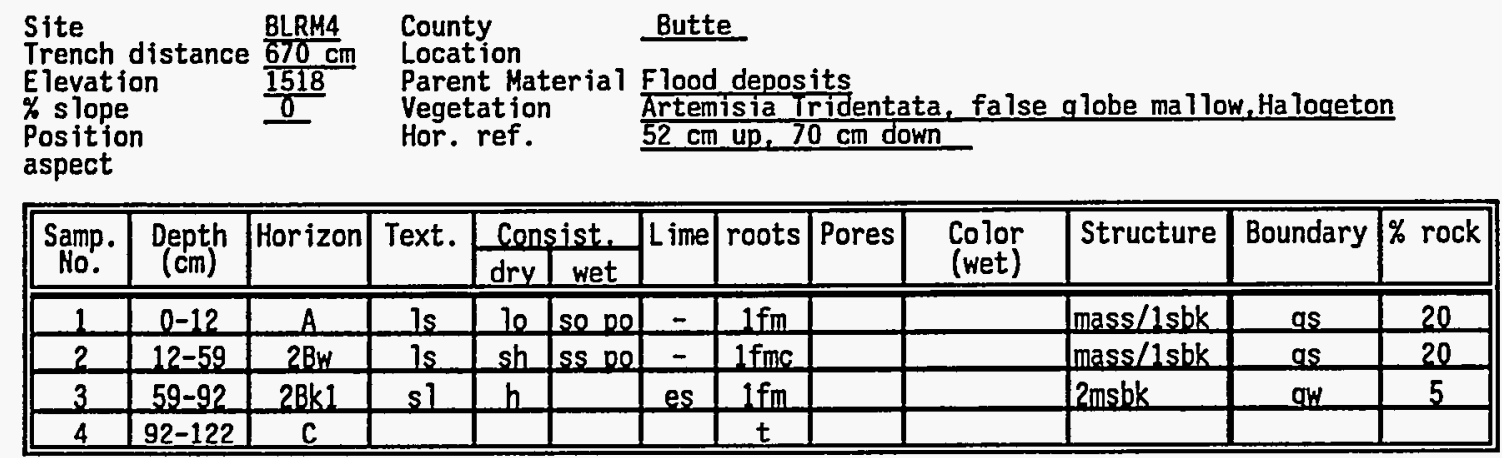

Comments:

\begin{tabular}{|c|c|c|c|c|c|c|c|c|c|c|}
\hline \multirow{2}{*}{$\begin{array}{c}\text { Samp. } \\
\text { No. }\end{array}$} & \multirow{2}{*}{$\begin{array}{c}\text { Depth } \\
\text { (cm) }\end{array}$} & \multirow[t]{2}{*}{ Horizon } & \multicolumn{3}{|c|}{ Particle size } & \multirow{2}{*}{$\begin{array}{l}\text { Text. } \\
\text { class }\end{array}$} & \multirow{2}{*}{$\begin{array}{l}\text { sat \% } \\
\text { water }\end{array}$} & \multirow[t]{2}{*}{$\mathrm{pH}$} & \multirow{2}{*}{$\underset{(\mathrm{m} S / \mathrm{cm})^{2}}{E C}$} & \multirow{2}{*}{$\underset{\%}{\mathrm{CaC03}}$} \\
\hline & & & $\%$ sand & $\%$ silt & \% clay & & & & & \\
\hline 1 & $0-12$ & A & 73.18 & $20 / 36$ & 6.46 & ls & 31.0 & 6.9 & $1.78^{1}$ & 1.1 \\
\hline 2 & $12-59$ & $2 B \mathrm{BH}$ & 66.34 & 27.51 & 5.93 & s] & 36.2 & 8.3 & $0.47^{1}$ & 1.9 \\
\hline 3 & $59-92$ & $2 \mathrm{Bk} 1$ & 26.09 & 63,18 & 10,73 & sil & 41.9 & 8.3 & $0.29^{2}$ & 15.9 \\
\hline 4 & $92-122$ & C & & & & & & & & \\
\hline
\end{tabular}

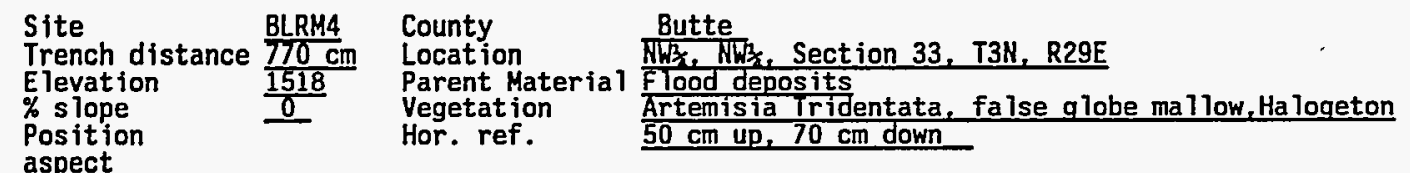

\begin{tabular}{|c|c|c|c|c|c|c|c|c|c|c|c|c|}
\hline $\begin{array}{c}\text { Samp. } \\
\text { No. }\end{array}$ & $\begin{array}{c}\text { Depth } \\
\text { (cm) }\end{array}$ & Horizon & Text. & $\frac{\text { Con }}{d r y}$ & $\begin{array}{l}\text { ist. } \\
\text { wet }\end{array}$ & Lime & roots & Pores & $\begin{array}{l}\text { Color } \\
\text { (wet) }\end{array}$ & Structure & Boundary & $\%$ rock \\
\hline 1 & $0-12$ & A & sand & 10 & so no & - & $1 \mathrm{fm}$ & & & Ifmar & as & 10 \\
\hline 2 & $12-27$ & $B w$ & ls & sh & so 00 & $=$ & $1 \mathrm{fmc}$ & & & $2 m c s b k$ & as & 10 \\
\hline 3 & $27-42$ & $2 B W$ & $1 \mathrm{~s}$ & sh & so Do & $e$ & $1 \mathrm{fmc}$ & & & 2msbk & as & 5 \\
\hline 4 & $42-80$ & $2 B \mathrm{~B} 1$ & s] & $h$ & so so & es & $t$ & & & 2msbk & $a_{W}$ & 5 \\
\hline 5 & $80-120$ & $3 C$ & grave1 & & & & $t$ & & & & & \\
\hline
\end{tabular}

Comments:

1. Mound position

2. Coarse gravel surface mantle.

\begin{tabular}{|c|c|c|c|c|c|c|c|c|c|c|}
\hline \multirow[t]{2}{*}{$\begin{array}{c}\text { Samp. } \\
\text { No. }\end{array}$} & \multirow[t]{2}{*}{$\begin{array}{l}\text { Depth } \\
\text { (cm) }\end{array}$} & \multirow[t]{2}{*}{ Horizon } & & $\begin{array}{c}\text { Particle } \\
\text { sjize } \\
\text { analysis }\end{array}$ & & \multirow[t]{2}{*}{ Texture } & \multirow[t]{2}{*}{$\begin{array}{l}\text { sat \% } \\
\text { water }\end{array}$} & \multirow[t]{2}{*}{$\mathrm{pH}$} & \multirow[t]{2}{*}{$\underset{(\mathrm{ms} / \mathrm{cm})^{2}}{\mathrm{EC}}$} & \multirow[t]{2}{*}{$\underset{\%}{\mathrm{CaCO} 3}$} \\
\hline & & & Sand & Silt & Clay & & & & & \\
\hline 1 & $0-12$ & A & 78.42 & 16.25 & 5.3 & ls. & 34.8 & 7.2 & $0.69^{1}$ & 0.6 \\
\hline 2 & $12-27$ & $\mathrm{Bw}$ & 73,92 & 19.33 & 6.74 & Is & 24.1 & 8.0 & $0.59^{1}$ & 0.6 \\
\hline 3 & $27-42$ & $2 \mathrm{BW}$ & & & & & 29.0 & 8.3 & $0,34^{1,3}$ & 5.1 \\
\hline 4 & $42-80$ & 2Bk1 & & & & & 38.3 & 8.4 & & 14.9 \\
\hline
\end{tabular}

Sample not stabilized - suspect reading 


\begin{tabular}{|c|c|c|c|c|c|c|c|c|c|c|c|c|}
\hline $\begin{array}{l}\text { Site } \\
\text { Trench } \\
\text { Elevati } \\
\text { \% slope } \\
\text { Positio } \\
\text { aspect }\end{array}$ & $\begin{array}{l}\text { distance } \\
\text { on } \\
\text { n }\end{array}$ & $\frac{\frac{\text { BLRM4 }}{880 \mathrm{~cm}}}{\frac{880}{1518}}$ & $\begin{array}{l}\text { Count } \\
\text { Locat } \\
\text { Parer } \\
\text { Veget } \\
\text { Hor. }\end{array}$ & $\begin{array}{l}\text { yon } \\
\text { ion Mat } \\
\text { ation } \\
\text { ref. }\end{array}$ & rial & $\begin{array}{l}\text { Butt } \\
\frac{\text { Flood }}{\text { Artem }} \\
\frac{36 \mathrm{~cm}}{6}\end{array}$ & $\begin{array}{l}\frac{e}{\text { depos }} \\
\frac{15 i a t}{40,8}\end{array}$ & $\frac{\text { its }}{\text { rident }}$ & $\mathrm{fals}$ & globe mallo & $\mathrm{A}, \mathrm{Ha}$ logeto & \\
\hline $\begin{array}{c}\text { Samp. } \\
\text { No. }\end{array}$ & $\begin{array}{l}\text { Depth } \\
\text { (cm) }\end{array}$ & Horizon & Text. & $\frac{\text { Con }}{d r y}$ & & Lime & roots & Pores & $\begin{array}{l}\text { Color } \\
\text { (wet) }\end{array}$ & Structure & Boundary & $\%$ rock \\
\hline 1 & $0-13$ & $\bar{A}$ & $7 \mathrm{~s}$ & 10 & so no & - & - & & & $12 \mathrm{fmar}$ & cs & 15 \\
\hline 2 & $13-37$ & $8 w$ & s1 & $h$ & so sp & - & $1 m c$ & & & $\operatorname{massive/c}_{\mathrm{sbk}}$ & gs & 5 \\
\hline 3 & $37-65$ & $2 \mathrm{Bk} 1$ & fs] & $h$ & ss_so & $e$ & tf & & & & cW & 5 \\
\hline 4 & $65-124$ & C & gravel & & & & & & & & & \\
\hline
\end{tabular}

Comments:

1. $\quad$ Mound position
2. Fine gravel surface mantle.
3. Combined the Bw and $2 \mathrm{Bw}$ horizons.

\begin{tabular}{|c|c|c|c|c|c|c|c|c|c|c|c|c|}
\hline $\begin{array}{l}\text { Site } \\
\text { Trench } \\
\text { Elevati } \\
\% \text { slope } \\
\text { Positio } \\
\text { aspect }\end{array}$ & $\begin{array}{l}\text { Jistance } \\
\text { n }\end{array}$ & $\frac{\frac{\mathrm{BLRH4}}{960 \mathrm{~cm}}}{0}$ & $\begin{array}{l}\text { Coun } \\
\text { Loca } \\
\text { Pare } \\
\text { Vege } \\
\text { Hor. }\end{array}$ & $\begin{array}{l}y \\
\text { ion } \\
\text { t Mat } \\
\text { atior } \\
\text { ref. }\end{array}$ & ial & 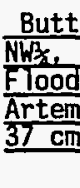 & $\frac{\frac{e}{N W_{3}, S}}{\text { depos }}$ & $\begin{array}{l}\frac{\text { ection }}{\text { its }} \\
\frac{\text { rident }}{0 \mathrm{~cm} d \mathrm{~d}}\end{array}$ & $\frac{3, \mathrm{~T} 3 \mathrm{~N}}{\mathrm{a}, \mathrm{fal}}$ & globe ma 110 & Ha logetor & \\
\hline $\begin{array}{c}\text { Samp. } \\
\text { No. }\end{array}$ & $\begin{array}{c}\text { Depth } \\
\text { (cm) }\end{array}$ & Horizon & Text. & $\frac{\text { Con }}{d r y}$ & ist. & Lime & roots & Pores & $\begin{array}{l}\text { Color } \\
\text { (wet) }\end{array}$ & Structure & Boundary & $\%$ rock \\
\hline 1 & $0-8$ & A & sand & 10 & SO DO & - & - & & & 1 far & gs & 10 \\
\hline 2 & $8-22$ & $B w$ & ls & sh & SS DO & - & $\mathrm{tm}$ & & & lcssh & cs & 5 \\
\hline 3 & $22-32$ & $2 B \mathrm{~W}$ & 15 & sh & SO DO & - & $2 m c$ & & & $1 \mathrm{csbk}$ & $\mathrm{CW}$ & 5 \\
\hline 4 & $32-42$ & $2 B k 1$ & ls & $\mathrm{h}$ & so po & $e$ & if & & & $3 c s b k$ & CW & 5 \\
\hline 5 & $42-127$ & $3 c$ & Gravel & & & & $1 f$ & & & & & \\
\hline
\end{tabular}

\section{Comments:}

1. Hound/intermound boundary
2. Horizon 3 contains a smal1 $(10 \times 20 \mathrm{~cm})$ pocket of gravel with $\mathrm{CaCO}^{3}$ on the bottom of the clasts.

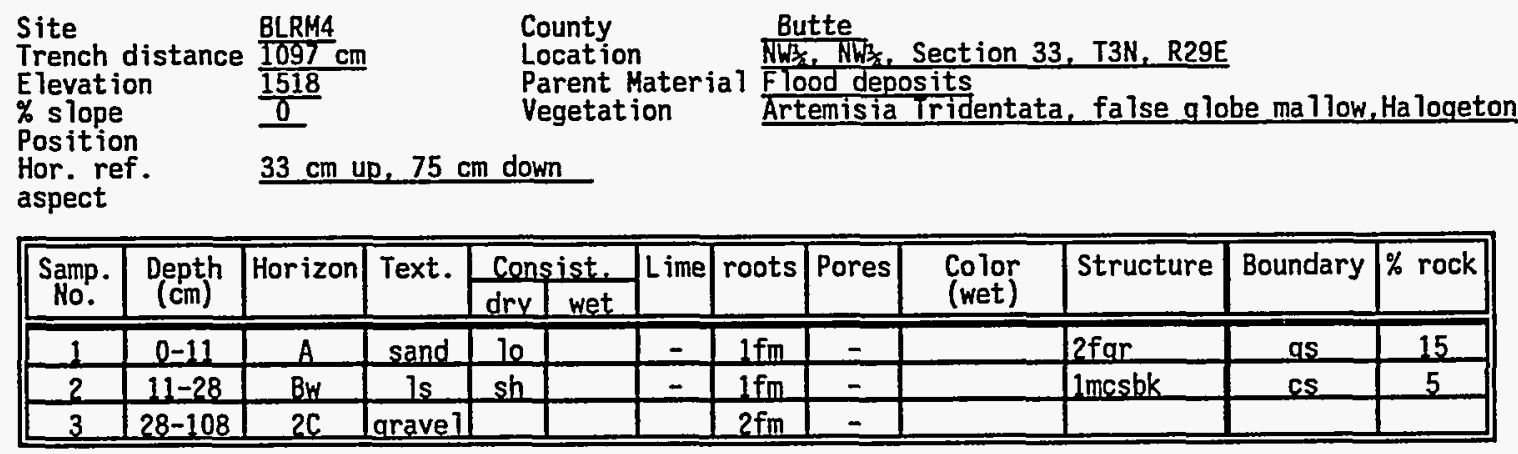

Comments:

1. Intermound position

2. Horizon 3 is comprised of bedded gravel with sand matrix. Gravels are coarser at this end of the trench, and have thicker caliche coats.

\begin{tabular}{|c|c|c|c|c|c|c|c|c|c|c|}
\hline \multirow{2}{*}{$\begin{array}{c}\text { Samp. } \\
\text { No. }\end{array}$} & \multirow{2}{*}{$\begin{array}{l}\text { Depth } \\
\text { (cm) }\end{array}$} & \multirow[t]{2}{*}{ Horizon } & \multicolumn{3}{|c|}{ Particle size } & \multirow{2}{*}{$\begin{array}{l}\text { Text. } \\
\text { class }\end{array}$} & \multirow{2}{*}{$\begin{array}{l}\text { sat } \% \\
\text { water }\end{array}$} & \multirow[t]{2}{*}{$\mathrm{pH}$} & \multirow{2}{*}{$\begin{array}{c}E C \\
(\mathrm{mS} / \mathrm{cm})\end{array}$} & \multirow{2}{*}{$\begin{array}{c}\mathrm{CaCO} 3 \\
\%\end{array}$} \\
\hline & & & $\%$ sand & $\%$ silt & $\%$ clay & & & & & \\
\hline 1 & $0-11$ & $A$ & 76.82 & 19.94 & 3.24 & Is & 23.6 & 6.5 & 0.60 & 0.7 \\
\hline 2 & $11-28$ & $B w$ & 66.2 & 26.1 & 7.7 & s] & 30.3 & 7.6 & 0.32 & 1.3 \\
\hline 3 & $28-108$ & $2 \mathrm{C}$ & 92.2 & 3.6 & 4.3 & sand & 22.3 & 8.2 & 0.22 & 2.7 \\
\hline
\end{tabular}




\begin{tabular}{|c|c|c|c|c|c|c|c|c|c|c|c|c|}
\hline $\begin{array}{l}\text { Site } \\
\text { Trench } \\
\text { Elevat } \\
\text { \% slop } \\
\text { Positi } \\
\text { aspect }\end{array}$ & distance & $\frac{\frac{\text { RWMCM1 }}{100 \mathrm{Cm}}}{\frac{5020}{\frac{5}{\text { near to }}}} \frac{\text { west fa }}{\text { we }}$ & $\frac{\mathrm{e} \text { of } \mathrm{s}}{\text { cing }}$ & ope & & $\begin{array}{l}\text { Coun } \\
\text { Loca } \\
\text { Pare } \\
\text { Vege } \\
\text { Hor. }\end{array}$ & $\begin{array}{l}\text { Ey } \\
\text { eion } \\
\text { it Hat } \\
\text { tation } \\
\text { ref. }\end{array}$ & rial? & 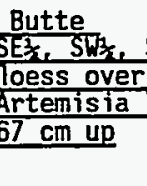 & $\begin{array}{l}\text { jection } 18, T \\
\frac{\text { basalt }}{\text { ridentata, }}\end{array}$ & R29E & \\
\hline $\begin{array}{l}\text { Samp. } \\
\text { No. }\end{array}$ & $\begin{array}{c}\text { Depth } \\
\text { (cm) }\end{array}$ & Horizon & Text. & Cor & ist. & Lime & roots & Pores & $\begin{array}{l}\text { Color } \\
\text { (wet) }\end{array}$ & Structure & Boundary & $\%$ rock \\
\hline 1 & $0-9$ & $A$ & sil & 10 & so 00 & e & 2 vff & yes & 10YR3/4 & 1fmar & cs & \\
\hline 2 & $9-36$ & $\mathrm{AB}$ & sil & 10 & ss Do & e & lvff & Ivffm & 10YR3/4 & 1-2msbk & cs & \\
\hline 3 & $36-81$ & Bk1 & sil & $y h$ & so so & es & $\mathrm{tfm}$ & 3vffm & 10YR5/3 & 3 fmabk & qs & \\
\hline 4 & $81-118$ & Bk? & sil & vh & so $\mathrm{sp}$ & es & tf & 2vffm & 10YR5/3 & 2 fmsbk & as & \\
\hline 5 & $\begin{array}{l}118- \\
140+\end{array}$ & $\mathrm{BC}$ & 1 & $\mathrm{~h}$ & so po & es & - & $2 \mathrm{fm}$ & 10YR4/4 & mass/1fmsbk & & \\
\hline
\end{tabular}

Comments:

1. Intermound position at toe of slope.

2. Basalt rubble up to $30 \mathrm{~cm}$ in diameter are mixed in with the Bk1 and Bk2 horizons within a meter from the end of the trench.

\begin{tabular}{|c|c|c|c|c|c|c|c|c|c|c|c|c|}
\hline $\begin{array}{l}\text { Site } \\
\text { Trench } \\
\text { Elevati } \\
\% \text { slope } \\
\text { Positio } \\
\text { aspect }\end{array}$ & $\begin{array}{l}\text { distance } \\
\text { on } \\
n\end{array}$ & $\begin{array}{l}\frac{\text { RWMCM1 }}{515 \mathrm{Cm}} \\
\frac{5020}{5} \\
\frac{\text { near to }}{\text { slope t }}\end{array}$ & $\begin{array}{l}\text { Count } \\
\text { Locat } \\
\text { Parer } \\
\text { Veget } \\
\text { of } \mathbf{s} \\
\text { aced } w e\end{array}$ & $\begin{array}{l}\text { Hat } \\
\text { Mtion } \\
\text { ape } \\
\text { st }\end{array}$ & erial & $\frac{\frac{\text { Butt }}{\text { SEt. }^{\frac{1}{2}}}}{\frac{\text { Ioess }}{\text { Artem }}}$ & $\frac{\frac{e}{\text { SWres, }}}{\text { over }}$ & 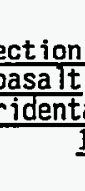 & $\begin{array}{l}18, \mathrm{~T}_{2} \mathrm{~N} \\
5 \mathrm{~cm} \text { up } \\
\mathrm{a}, \mathrm{c}\end{array}$ & & & \\
\hline $\begin{array}{l}\text { Samp. } \\
\text { No. }\end{array}$ & $\begin{array}{c}\text { Depth } \\
\text { (cm) }\end{array}$ & Horizon & Text. & Cons & $\begin{array}{l}\text { ist. } \\
\text { wet }\end{array}$ & Lime & roots & Pores & $\begin{array}{l}\text { Color } \\
\text { (wet) }\end{array}$ & Structure & Boundary & $\%$ rock \\
\hline 1 & $0-75$ & $\begin{array}{c}A B \\
\text { mixed }\end{array}$ & sil & so & ss sp & es & $\begin{array}{c}2 v f f / \\
1 \mathrm{~m}\end{array}$ & $\begin{array}{c}3 \mathrm{vff} / \\
1 \mathrm{~m}\end{array}$ & 10YR3/3 & mass/1fmsbk & $\mathbf{C H}$ & \\
\hline 2 & $75-109$ & Bk1 & sil & $h$ & ss sp & es & tyff & Ivff & 10YR5/3 & 3 msbk & qW & \\
\hline 3 & $109-139$ & Bk? & sil & h & ss so & es & $\operatorname{trf}$ & lyff & $10 Y R 4 / 3$ & 2 fmabk & qw & $5-10$ \\
\hline 4 & $139-162$ & Bk3 3 & & sh & so 0 & es & tyff & 2vff & 10YR4/4 & $2 \mathrm{fmsbk}$ & CW & 30 \\
\hline 5 & $\begin{array}{l}162- \\
190+ \\
\end{array}$ & Btkb & & sh & ss $s p$ & es & $t$ & $2 v f f$ & 10YR4/3 & mass/2fmsbk & & \\
\hline
\end{tabular}

\section{Comments:}

1. Profile position is downslope of a highly bioturbated zone, and within the mound soil.

2. The $A B$ horizon is mixed $A, A B$, and some $B k$ due to bioturbation. The horizon exhibits a relict $A$ horizon platy vesicular structure in places. Relict $A B$ and $B K$ horizons are also recognizable in a very few places with in the horizon $(5-10 \%)$.

3. $20 \%$ krotovinas $2-5 \mathrm{~cm}$ diameter in the $\mathrm{BK}$ horizons.

4. Gravels in the BK2 are up to $5-10 \%$, and in the BK3 up to $30 \%$.

5. A large animal burrow occupies the Bk3. Dimensions are $\approx 150-180 \mathrm{~cm}$ high and $50 \mathrm{~cm}$ wide. Filled with loose soil, bones, and organic matter.

6. Top of Btkb horizon at base of shovel pit.

\begin{tabular}{|c|c|c|c|c|c|c|c|c|c|c|c|c|}
\hline $\begin{array}{l}\text { Site } \\
\text { Trench } \\
\text { Elevati } \\
\% \text { slope } \\
\text { Positio } \\
\text { Aspect }\end{array}$ & $\begin{array}{l}\text { distance } \\
\text { on }\end{array}$ & $\frac{\frac{\text { RWMCM1 }}{1120 \mathrm{~cm}}}{\frac{5020}{\frac{5}{\text { near to }}}}$ & of $s$ & ope & & $\begin{array}{l}\text { Coun } \\
\text { Loca } \\
\text { Pare } \\
\text { Vege } \\
\text { Hor. }\end{array}$ & $\begin{array}{l}\text { y } \\
\text { it Mate } \\
\text { it Mation } \\
\text { ref. }\end{array}$ & ial $\frac{\bar{S}}{\underline{A}}$ & 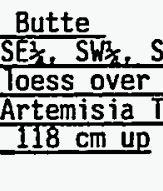 & $\frac{\text { Section } 18, \text { T2N }}{\text { basalt }}$ & R29E & \\
\hline $\begin{array}{l}\text { Samp. } \\
\text { No. }\end{array}$ & $\begin{array}{c}\text { Depth } \\
(\mathrm{cm})\end{array}$ & Horizon & Text. & $\frac{\text { Con }}{d r y}$ & $\begin{array}{l}\text { ist. } \\
\text { wet }\end{array}$ & Lime & roots & Pores & $\begin{array}{l}\text { Color } \\
\text { (wet) }\end{array}$ & Structure & Boundary & $\%$ rock \\
\hline 1 & $0-8$ & A & & 10 & ss ps & eo & $2 v f f m$ & $3 v f f$ & & & & \\
\hline 2 & $8-20$ & $\overline{A B}$ & sil & 10 & ss ns & $e$ & $2 v f f m$ & $3 v f f$ & $10 Y R 3 / 3$ & $1 \mathrm{msbk} / 1 \mathrm{fmgr}$ & & \\
\hline 3 & $20-40$ & $8 \mathrm{k} 1$ & sil & 10 & ss os & es & 2vffm & 3vff & $10 Y R 4 / 4$ & $1 \mathrm{mcsbk}$ & cW & \\
\hline 4 & $40-67$ & $\mathrm{Bk} 2$ & sil & vh & ss ns & ev & 2vffm & $2 v \mathrm{ffm}$ & 10YR5/4 & 2 fmabk & aw & \\
\hline 5 & $67-85$ & & & & & es & & & & & aw & \\
\hline 6 & $85-110$ & Bkom & & & & es & & & & mass/2mcol & ai & \\
\hline 7 & $\begin{array}{l}110- \\
140+\end{array}$ & Bkq & & & & es & tvff & $2 v f f$ & 10YR4/3 & mass/2mcp 1 & $a i$ & \\
\hline
\end{tabular}


Corments:

1. Ups lope intermound position.

2. The BK horizons are discont inuous due to bioturbation.

3. Bkqm is indurated, as is the bottom of the Bkq. These horizons are following the slope of the

basalt rubble, which is interpreted as an old soil surface.

4. $67-85 \mathrm{~cm}$ is a large krotovina which disturbed the top of the Bkqm.

\begin{tabular}{|c|c|c|c|c|c|c|c|c|c|c|c|c|}
\hline $\begin{array}{l}\text { Site } \\
\text { Trench } \\
\text { Elevati } \\
\text { \% slope } \\
\text { Positio } \\
\text { Aspect }\end{array}$ & $\begin{array}{l}\text { distance } \\
\text { on } \\
\text { n }\end{array}$ & $\begin{array}{l}\frac{\text { IPH2 }}{50 \mathrm{~cm}} \\
\frac{5060}{1} \\
\frac{1}{\text { near to }} \\
\text { slope f }\end{array}$ & $\frac{e \text { of } s 1}{\text { aced } e a}$ & & & $\begin{array}{l}\text { Count } \\
\text { Locat } \\
\text { Paren } \\
\text { Veget } \\
\text { Hor. }\end{array}$ & $\begin{array}{l}\text { y } \\
\text { it Mate } \\
\text { tation } \\
\text { ref. }\end{array}$ & ial & 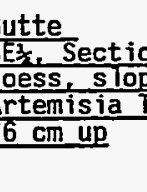 & $\begin{array}{l}\text { 19, T2N, R } \\
\text { ewash(?) ove } \\
\text { ridentata, }\end{array}$ & $\frac{29 E}{2 \text { basa } 7 t}$ & \\
\hline $\begin{array}{l}\text { Samp. } \\
\text { Ho. }\end{array}$ & $\begin{array}{l}\text { Depth } \\
\text { (cm) }\end{array}$ & Horizon & Text. & Cons & ist & Lime & roots & Pores & $\begin{array}{l}\text { Color } \\
\text { (wet) }\end{array}$ & Structure & Boundary & $\%$ rock \\
\hline 1 & $0-9$ & A & sil & so & so no & eo & $3 v f f m$ & & 10YR $4 / 3$ & 3vffmar & cs & \\
\hline 2 & $9-22$ & $B w$ & sil/15 & so & ss_ps & eo & 2yffm & & $10 Y R 4 / 3$ & $2 \mathrm{fmsbk}$ & cs & \\
\hline 3 & $22-45$ & Bk1 & sil $/ 15$ & sh & Sens & eo & $1 \mathrm{fm}$ & & $10 Y R 4 / 3$ & $3 m c s b k$ & gs & \\
\hline 4 & $45-63$ & Bk? & sil & sh & & ev & trfm & & 10YR5/3 & $3 \mathrm{fmabk}$ & vas & \\
\hline 5 & $63-90$ & 2Bk1 & vfs? & sh & & ev & trf & & 10YR5/3 & $\operatorname{mass}_{\mathrm{bk}} / 1 \mathrm{fms}$ & vgs & \\
\hline 6 & $90-103$ & $2 \mathrm{Bk} 2$ & vfs I & sh & & ev & - & & $10 Y R 5 / 3$ & $\operatorname{mass}_{\mathrm{bk}} / 1 \mathrm{fms}$ & vgw & \\
\hline 7 & $103-130$ & $2 \mathrm{Bk} 3$ & s] & So & & ev & $=$ & & 10YR4/4 & Imass/2far & $C$ & \\
\hline
\end{tabular}

Comments:

1. Ups lope intermound position.

2. The $2 B \mathrm{~K}$ and $3 \mathrm{BK} 1$ contain rounded basalt clasts up to $2 \mathrm{~mm}$ diameter $(<1 \%)$.

3. The $3 B k 1$ is tricky to texture. It gets heavier with continued work.

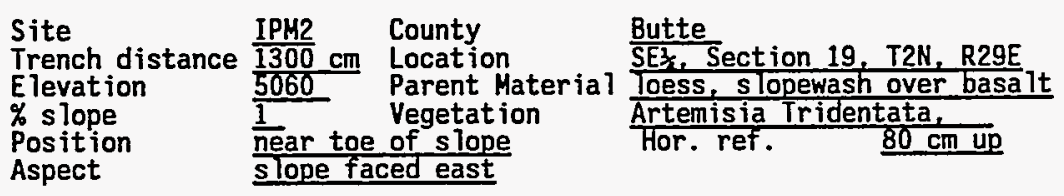

\begin{tabular}{|c|c|c|c|c|c|c|c|c|c|c|c|c|}
\hline $\begin{array}{l}\text { Samp. } \\
\text { No. }\end{array}$ & $\begin{array}{c}\text { Depth } \\
\text { (cm) }\end{array}$ & Horizon & Text. & Cons & ist & Lime & roots & Pores & $\begin{array}{l}\text { Color } \\
\text { (wet) }\end{array}$ & Structure & Boundary & $\%$ rock \\
\hline 1 & $0-7$ & A & 1 & so & ss os & eo & $3 \mathrm{fc}$ & & $10 Y R 3 / 3$ & $1 \mathrm{fmar}$ & cs & \\
\hline 2 & $7-21$ & $A B$ & sil & so & ss os & eo & $3 f c$ & & 10YR $4 / 3$ & 2mcsbk & cs & \\
\hline 3 & $21-42$ & Bk1 & sil & sh & ss ns & e & $2 \mathrm{fm}$ & & $10 Y R 4 / 3$ & $2 \mathrm{fmsbk}$ & aw & \\
\hline 4 & $42-61$ & Bk? & sil & sh & ss ps & es & $1 \mathrm{fm}$ & & $10 Y R 4 / 3$ & 3 masble & $a_{y-}$ & \\
\hline 5 & $61-98$ & $2 \mathrm{Bk} 1$ & vfs l & sh & so po & es & trfm & & $10 Y R 5 / 3$ & massive & ci & \\
\hline 6 & $98-112$ & $2 B k 2$ & vfs l & h & so po & es & trfm & $2 \mathrm{fm}$ & 10YR6/4 & $\operatorname{mass}_{\mathrm{bk}} / 2 \mathrm{fma}$ & $c \mathfrak{i}$ & \\
\hline 7 & $112-140$ & $2 \mathrm{Bk} 3$ & vfs 1 & $\overline{v h}$ & so po & e & - & & $7.5 Y R 4 / 4$ & $\operatorname{mass}_{\mathrm{bk}} / 2 \mathrm{fma}$ & & \\
\hline
\end{tabular}

Comments:

1. Downs lope intermound position.

2. The Bk1 has $1 \%$ rounded basalt clasts up to $2 \mathrm{~mm}$ diameter.

3. The $2 B K 1$ has basalt sand visible without a lens.

4. Horizon 2Bk2 breaks up int coarse and very coarse granular peds that are difficult to texture. The

5. The $2 \mathrm{Bk} 3$ has secondary $\mathrm{CaCO}^{3}$ stringers in root veins. The horizon is mottled with a light rust

6. The $2 B k 2$ and $2 B k 3$ have basalt clasts $15-40 \mathrm{~cm}$ in diameter oriented as upright columns

7. Paul Benedict from the SCS (Pocatel lo office) noted an unusual fragipan character to the $2 B k 2$ and $2 B k 3$ horizons. 


\section{Site}

rench distance $\frac{260 \mathrm{~cm}}{2600}$

Elevation

\% slope

Position

Aspect SW
County

Location

Parent Material slopewash

Vegetation

Big Saqebrus

Hor. ref.

Butte intertat
Mound: Halogeton: Intermound: Crested wheatgrass,

near outcrop at top

\begin{tabular}{|c|c|c|c|c|c|c|c|c|c|c|c|c|}
\hline $\begin{array}{l}\text { Samp. } \\
\text { No. }\end{array}$ & $\begin{array}{l}\text { Depth } \\
\text { (cm) }\end{array}$ & Horizon & Text. & $\frac{\text { Con }}{d r y}$ & wet & Lime & roots & Pores & $\begin{array}{l}\text { Color } \\
\text { (wet) }\end{array}$ & Structure & Boundary & $\%$ rock \\
\hline 1 & $0-15$ & $\bar{A}$ & fs] & 10 & ss so & es & $3 \times f, f$ & - & 10YR $4.5 / 3$ & $2 \mathrm{fm}$ ar & - & - \\
\hline 2 & $15-24$ & $B k$ & $\operatorname{sil} / 30$ & sh & ss sp & es & $2 v f . f$ & - & 10YR $6 / 3$ & $3 \mathrm{fm}$ ar & $=$ & - \\
\hline 3 & $24-34$ & Btk & sil $/ 35$ & sh & ss sp & es & livff & $2 y f f$ & 10YR $6 / 3$ & $3 f$ sbk & - & - \\
\hline 4 & $34-60$ & 28tklb & sil $/ 35$ & h & ss sp & es & lvf $f$ & $2 x f, f$ & $10 Y R 6 / 3$ & $3 m-c$ sbk & $=$ & $=$ \\
\hline 5 & $60-99$ & $2 B t k 2 b$ & sicl & sh & - & es & $t$ & $3 v f, f$ & 10YR $7 / 3$ & $\begin{array}{l}\operatorname{mass} / f m \\
\text { sbk }\end{array}$ & - & - \\
\hline
\end{tabular}

Comments:

1. Profile is an intermound position.

2. All horizons contain basalt sand and appear to be slopewash.

3. At $225-255 \mathrm{~cm}$ (left of profile) is a dark wedge, filled with sil/25, in the Btk and $2 \mathrm{Btk} 1 \mathrm{~b}$ units The wedge is $30 \mathrm{~cm}$ wide at the top to a position $27 \mathrm{~cm}$ below the reference 1 ine where it thins to $1 \mathrm{~cm}$ to the bedrock at the bottom of the trench.

4. A second $f j$ lied structure is at $280-308 \mathrm{~cm}$ occupying part of the $2 B$ tk1b and $2 B+k 2 b$. This structure is rounded with a narrow pipe at the upper surface extending to the top of the 28 tk 16 . The filing is the same darker color and texture as the wedge left of the profile. It does not extend to bedrock, and is interpreted to be a krotovina.

\begin{tabular}{|c|c|c|c|c|c|}
\hline $\begin{array}{c}\text { Samp. } \\
\text { No. }\end{array}$ & $\begin{array}{c}\text { Depth } \\
(\mathrm{cm})\end{array}$ & Horizon & $\mathrm{pH}$ & $\mathrm{EC}$ & CaC03 \% \\
\hline 1 & $0-15$ & $\mathrm{~A}$ & 8.0 & 0.51 & 14.7 \\
\hline 2 & $15-24$ & Bk & 8.3 & 0.96 & 14.6 \\
\hline 3 & $24-34$ & Btk & & & \\
\hline 4 & $34-60$ & 28 tk1b & 7.7 & 2.03 & 21 \\
\hline 5 & $60-99$ & 2 Btk2b & 8.3 & 14.5 & 15.8 \\
\hline
\end{tabular}

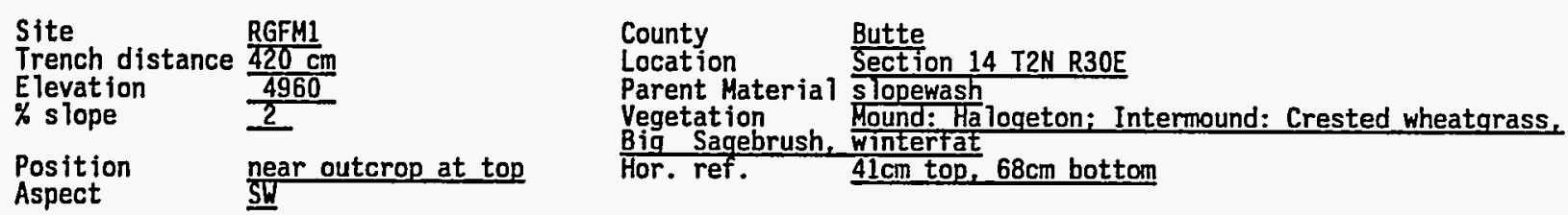

\begin{tabular}{|c|c|c|c|c|c|c|c|c|c|c|c|c|}
\hline $\begin{array}{l}\text { Samp. } \\
\text { No. }\end{array}$ & $\begin{array}{c}\text { Depth } \\
\text { (cm) }\end{array}$ & Horizon & Text. & $\frac{\text { Con }}{d r y}$ & $\begin{array}{l}\text { sist. } \\
\text { wet }\end{array}$ & Lime & roots & Pores & $\begin{array}{l}\text { Color } \\
\text { (wet) }\end{array}$ & Structure & Boundary & $\%$ rock \\
\hline 1 & $0-10$ & A & fs] & 10 & Ss Do & es & $2 f, m$ & - & 10YR $5 / 3$ & $2 \mathrm{fm}$ or & cW & - \\
\hline 2 & $10-20$ & Btk & $\operatorname{sil} / 30$ & $\mathrm{~h}$ & ss sp & es & $2 f, m$ & 2yfif & 10YR $6 / 3$ & $3 \mathrm{fm} s \mathrm{sk}$ & $\mathrm{cW}$ & - \\
\hline 3 & $20-46$ & $2 B+k 1 b$ & sil/35 & $\mathrm{h}$ & ss 0 & es & Ifm & $2 v f f$ & 10YR $6 / 3$ & $2 m-c$ sbl & qw & - \\
\hline 4 & $46-56$ & $2 B+k 1 b$ & $\mathrm{sil} / 35$ & $h$ & so & es & tr & $3 \times f, f$ & 10YR $6 / 3$ & $1 m-c$ sbk & gs & - \\
\hline 5 & $56-109$ & 2Btk2b & cl & sh & - & $\begin{array}{l}\text { es- } \\
\text { ev }\end{array}$ & - & $3 v f, f$ & 10YR $7.5 / 3$ & $\operatorname{lfm}_{\text {sbk }} \mathrm{p} 1 / 2 \mathrm{~m}$ & & - \\
\hline
\end{tabular}

Coments:

1. Intermound position, significant bioturbation on the moundward side of the profile.

2. $30 \%$ cicadas in 28 tki. Color is blotchy - filled burrows, wedge fillings, or convolutions?

3. Basal unit is platy in place but breaks into sbk. $<5 \%$ basalt clasts to $3 \mathrm{~cm}$.

4. Sediment directly on top and in the surface cracks in the basalt bedrock has a reddish color. 


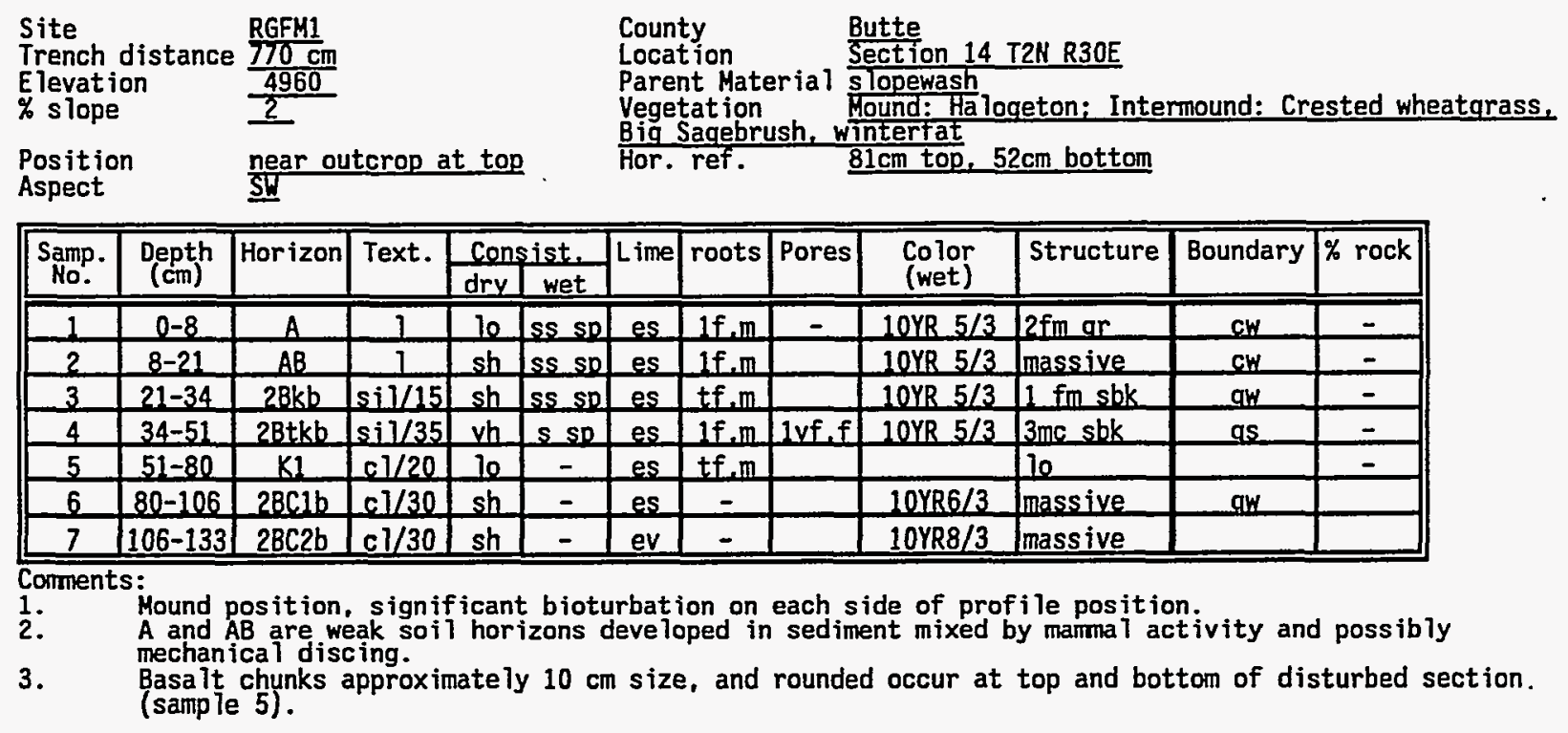

\begin{tabular}{|c|c|c|c|c|c|c|c|c|c|c|c|c|}
\hline \multicolumn{2}{|c|}{$\begin{array}{l}\text { Site } \\
\text { Trench distance } \\
\text { Elevation } \\
\text { \% slope } \\
\text { Position } \\
\text { Aspect SW }\end{array}$} & $\frac{\frac{\text { RGFH1 }}{930 \mathrm{~cm}}}{\frac{4960}{2}}$ & tcrop a & it top & & \multicolumn{3}{|c|}{$\begin{array}{l}\text { County } \\
\text { Location } \\
\text { Parent Material } \\
\text { Vegetation } \\
\text { Big Sagebrush, } \\
\text { Hor. ref. }\end{array}$} & \multicolumn{2}{|c|}{$\begin{array}{l}\text { Butte } \\
\text { Section } 14 \text { T2N R3OE } \\
\text { Slopewash } \\
\text { Hound: Halogeton: Inte } \\
94 \mathrm{~cm} \text { top, } 35 \mathrm{~cm} \text { bottom }\end{array}$} & \multicolumn{2}{|c|}{$\begin{array}{l}\text { mound: Crested wheatgrass, } \\
\text { winterfat }\end{array}$} \\
\hline \begin{tabular}{c|} 
Samp. \\
No.
\end{tabular} & $\begin{array}{l}\text { Depth } \\
\text { (cm) }\end{array}$ & Horizon & Text. & \begin{tabular}{|c|} 
Cons \\
dry \\
\end{tabular} & ist. & Lime & roots & Pores & $\begin{array}{l}\text { Color } \\
\text { (wet) }\end{array}$ & Structure & Boundary & $\%$ rock \\
\hline 1 & $0-26$ & $A w$ & 1 & 10 & ss $\mathrm{sp}$ & es & Ivf,f & & & $\operatorname{massive/f}_{\mathrm{ar}}$ & $\mathrm{CW}$ & - \\
\hline 2 & $26-42$ & $2 B k 1 b$ & sil & sh & ss_sp & es & lvfef & lvf,f & & $2 \mathrm{fm}$ sbk & CH & - \\
\hline 3 & $42-56$ & $2 \mathrm{Bk} 2 \mathrm{~b}$ & c] $1 / 35$ & sh & $s$ so & es & lvf.f & 1vfif & & $2 m$ sbk & $g_{w}$ & - \\
\hline 4 & $56-75$ & $2 \mathrm{Bk} 3 \mathrm{~b}$ & c] $1 / 35$ & $h$ & s so & es & lvf,f & $2 v f, f$ & & $2 m$ sbk & qs & - \\
\hline 5 & $75=104$ & 2Btk1b & c] $1 / 25$ & sh & ss 0 & es & - & $2 v f, f$ & & massive & & - \\
\hline 6 & 104-129 & 2Btk2b & c) $1 / 30$ & sh & $s \mathbf{s p}$ & ev & - & $2 v f, f$ & & massive & qW & . \\
\hline $\begin{array}{l}1 . \\
2 . \\
3 . \\
4 .\end{array}$ & $\begin{array}{l}\text { Round } \\
\text { No be } \\
\text { Preci } \\
\text { The A } \\
\text { prism }\end{array}$ & izol & $f$ & & ixe & soi & . & a & $20 \mathrm{~cm}$ & levelope & andoma & very co \\
\hline
\end{tabular}

\begin{tabular}{|c|c|c|c|c|c|c|c|c|c|}
\hline \multirow{2}{*}{$\begin{array}{l}\text { Samp. } \\
\text { No. }\end{array}$} & \multirow[t]{2}{*}{ Depth } & \multirow[t]{2}{*}{ Horizon } & \multicolumn{3}{|c|}{ Particle size } & \multirow{2}{*}{$\begin{array}{l}\text { Text. } \\
\text { class }\end{array}$} & \multirow[t]{2}{*}{$\mathrm{pH}$} & \multirow[t]{2}{*}{$E C$} & \multirow{2}{*}{$\underset{\%}{\mathrm{CaCO} 3}$} \\
\hline & & & $\%$ sand & $\%$ silt & \% clay & & & & \\
\hline 1 & $0-26$ & Aw & 49.3 & 23.4 & 24.5 & $\mathrm{sc}]$ & 8.3 & 1.81 & 14.7 \\
\hline 2 & $26-42$ & $2 B k 1 b$ & & & & & 7.9 & 14.3 & 14.6 \\
\hline 3 & $42-56$ & $2 B k 2 b$ & & & & & 7.8 & 22.6 & \\
\hline 4 & $56-75$ & $2 \mathrm{Bk} 3 \mathrm{~b}$ & 36.9 & 39,9 & 23.2 & 1 & 7.9 & 29.1 & 21 \\
\hline 5 & $75-104$ & 2Btkib & & & & & 8.1 & 29.7 & 15.8 \\
\hline 6 & 104-129 & $2 B+k 2 b$ & 16.6 & 25.4 & 55.3 & clay & 8,1 & 48.0 & \\
\hline
\end{tabular}




\begin{tabular}{|c|c|c|c|c|c|c|c|c|c|c|c|c|}
\hline $\begin{array}{l}\text { Site } \\
\text { Trench } \\
\text { Elevat } \\
\% \text { slope }\end{array}$ & $\begin{array}{l}\text { distance } \\
\text { ion }\end{array}$ & $\frac{\frac{\text { RGFM1 }}{1160 \mathrm{~cm}}}{\frac{4960}{2}}$ & n & & & $\begin{array}{l}\text { Coun } \\
\text { Loca } \\
\text { Parer } \\
\text { Veget } \\
\text { Big }\end{array}$ & $\begin{array}{l}\text { ty } \\
\text { tion } \\
\text { nt Mate } \\
\text { tation }\end{array}$ & erial & 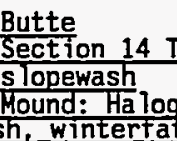 & $\frac{\text { I2N R3OE }}{\text { geton: Inter }}$ & rmound: $\mathrm{Cr}$ & ested wheatgrass, \\
\hline $\begin{array}{l}\text { Positic } \\
\text { Aspect }\end{array}$ & & $\begin{array}{l}\text { near ou } \\
\underline{\text { SW }}\end{array}$ & Itcrop a & $t$ tor & & Hor. & ref. & Din & $95 \mathrm{~cm}$ top, 46 & $\frac{\mathrm{c}}{\mathrm{c}} \mathrm{cm}$ bottom & & \\
\hline $\begin{array}{l}\text { Samp. } \\
\text { No. }\end{array}$ & $\begin{array}{l}\text { Depth } \\
\text { (cm) }\end{array}$ & Horizon & Text. & Con & sist. & Lime & roots & Pores & Color & Structure & Boundary & $\%$ rock \\
\hline 1 & $0-10$ & $\bar{A}$ & 1 & so & Iss so & es & $2 f . m$ & $1 f$ & 10YR $5 / 3$ & 2c sbk & cs & \\
\hline 2 & $10-47$ & BW & 1 & so & ss so & es & tyf.f & - & 10YR $5 / 3$ & $1 f-c$ sbk & - & \\
\hline 3 & $47-60$ & $28 \mathrm{k} 1 \mathrm{~B}$ & sil/20 & h & ss sp & es & $1 \mathrm{f}, \mathrm{m}$ & If & 10YR $5 / 3.5$ & $2 f$.m_sbk & $=$ & \\
\hline 4 & $60-79$ & $28 \mathrm{k} 2 \mathrm{~B}$ & $\mathrm{sil} / 20$ & h & ss $\mathrm{sp}$ & es & tf & - & 10YR $6.5 / 4$ & $\begin{array}{l}\operatorname{mass}_{\mathrm{sbk}} / 2 \mathrm{f}-\mathrm{c} \\
\end{array}$ & - & \\
\hline 5 & $79-114$ & $2 B t B$ & sicl & h & - & es & - & $2 f$ & 10YR $6 / 3.5$ & $\begin{array}{l}\operatorname{mass}_{\mathrm{shk}} / 2 \mathrm{f}-\mathrm{c} \\
\end{array}$ & - & \\
\hline 6 & 114-141 & 2BkB & sil/25 & sh & ss sp & es & - & $2 f$ & 10YR6/3.5 & $2 f-c$ sbk & - & \\
\hline $\begin{array}{l}\text { Commel } \\
1 . \\
2 . \\
3 . \\
4 . \\
5 . \\
6 .\end{array}$ & $\begin{array}{l}\text { S: } \\
\text { This pr } \\
\text { through } \\
\text { increas } \\
\text { Stringe } \\
\text { Units } 1 \\
\text { Unit } 3 \\
\text { Unit } 4 \\
A \text { and } B\end{array}$ & $\begin{array}{l}\text { hout the } \\
\text { se sign } \\
\text { ers of } \\
\text { and } 2 \\
\text { has } 40 \\
\text { has } 20 \%\end{array}$ & of & & $\begin{array}{l}\text { ith la } \\
\text { soi } \\
\text { che st } \\
\text { im are } \\
\text { iotur }\end{array}$ & $\begin{array}{l}\text { ged } \\
\text { exte } \\
\text { uctu } \\
\text { very } \\
\text { jated }\end{array}$ & $\begin{array}{l}\text { Jistur } \\
\text { ands } \\
\text { ure ch } \\
\text { evic }\end{array}$ & $\begin{array}{l}\text { d are } \\
\text { eral1 } \\
\text { ges. } \\
t \text { in }\end{array}$ & $\begin{array}{l}\text { eas on both } \\
\text { ly to } 1260 \mathrm{cr} \\
\text { The } 2 \mathrm{Btb} r \\
\text { units } 3-6 \text {. }\end{array}$ & $\begin{array}{l}\text { sides. } \\
\text { m, at whic } \\
\text { eplaces th }\end{array}$ & $\begin{array}{l}\text { rous kro } \\
\text { point th } \\
\text { platy ur }\end{array}$ & $\begin{array}{l}\text { ovinas are evident } \\
\text { krotovina } \\
\text { t seen laterally. }\end{array}$ \\
\hline
\end{tabular}

\begin{tabular}{|c|c|c|c|c|c|c|c|c|c|}
\hline \multirow{2}{*}{$\begin{array}{c}\text { Samp. } \\
\text { No. }\end{array}$} & \multirow[t]{2}{*}{ Depth } & \multirow[t]{2}{*}{ Horizon } & \multicolumn{3}{|c|}{ Particle size } & \multirow{2}{*}{$\begin{array}{l}\text { Text. } \\
\text { c lass }\end{array}$} & \multirow[t]{2}{*}{$\mathrm{pH}$} & \multirow[t]{2}{*}{$E C$} & \multirow{2}{*}{$\underset{\%}{\mathrm{CaCO3}}$} \\
\hline & & & $\%$ sand & $\%$ silt & $\%$ clay & & & & \\
\hline 1 & $0-47$ & A \& BW & & & & & 8.3 & 3.1 & \\
\hline 3 & $47-60$ & $2 \mathrm{Bk} 1 \mathrm{~b}$ & & & & & 7.5 & 17.9 & \\
\hline 4 & $60-79$ & $2 \mathrm{Bk} 2 \mathrm{~b}$ & 49.3 & 39,0 & 8.6 & 1 & 8.0 & 29.1 & \\
\hline 5 & $79-114$ & $28+b$ & & & & & 7.5 & 33.8 & \\
\hline 6 & $114-141$ & $2 \mathrm{Bkb}$ & & & & & 8.0 & 40.5 & \\
\hline
\end{tabular}

\begin{tabular}{|c|c|c|c|c|c|c|c|c|c|c|c|c|}
\hline \multirow{2}{*}{\multicolumn{2}{|c|}{$\begin{array}{l}\text { Site } \\
\text { Trench distance } \\
\text { Elevation } \\
\% \text { slope } \\
\text { Position } \\
\text { Aspect }\end{array}$}} & \multirow{2}{*}{\multicolumn{4}{|c|}{$\begin{array}{l}\frac{\frac{R G F M 1}{1310} \mathrm{~cm}}{4960} \\
\frac{2}{2} \\
\frac{\text { near outcrop at top }}{\text { SW }}\end{array}$}} & \multirow{2}{*}{\multicolumn{3}{|c|}{$\begin{array}{l}\text { County } \\
\text { Location } \\
\text { Parent Haterial } \\
\text { Vegetation } \\
\text { Bige Sagebrush, W } \\
\text { Hor. ref. }\end{array}$}} & \multirow{2}{*}{\multicolumn{2}{|c|}{$\begin{array}{l}\text { Butte } \\
\text { Section } 14 \text { T2N R31E } \\
\text { Slopewash } \\
\text { Mound: Ha logeton; Int } \\
\text { Wintertat } \\
\text { 92cm top, } 46 \mathrm{~cm} \text { bottom }\end{array}$}} & \multirow{2}{*}{\multicolumn{2}{|c|}{ Crested wh }} \\
\hline & & & & & & & & & & & & \\
\hline \multirow{2}{*}{$\begin{array}{c}\text { Samp. } \\
\text { No. }\end{array}$} & \multirow{2}{*}{$\begin{array}{c}\text { Depth } \\
\text { (cm) }\end{array}$} & \multirow[t]{2}{*}{ Horizon } & \multirow[t]{2}{*}{ Text. } & \multicolumn{2}{|c|}{ Consist. } & \multirow[t]{2}{*}{ Lime } & \multirow[t]{2}{*}{ roots } & \multirow[t]{2}{*}{ Pores } & \multirow{2}{*}{$\begin{array}{l}\text { Color } \\
\text { (wet) }\end{array}$} & \multirow[t]{2}{*}{ Structure } & \multirow[t]{2}{*}{ Boundary } & \multirow[t]{2}{*}{$\%$ rock } \\
\hline & & & & & & & & & & & & \\
\hline 1 & $0-18$ & Aw & - & & - & - & - & - & - & L- & & \\
\hline 2 & $18-45$ & Bw & - & & $=$ & - & - & if & - & E & & \\
\hline 3 & $45-63$ & $28 \mathrm{k} 1 \mathrm{~b}$ & sil/20 & sh & - & - & - & $-1 f$ & - & - & - & \\
\hline 4 & $63-88$ & $2 B \mathrm{k} 2 \mathrm{~b}$ & $\mathrm{sil} / 20$ & sh & ss os & - & - & $-2 f$ & $2 \mathrm{fmsbk}$ & L- & - & \\
\hline 5 & $88-132$ & $28 k 1 b$ & - & & - & - & - & $=$ & - & - & & \\
\hline 6 & $132-138$ & $2 k 2 b$ & - & & - & - & - & - & - & E & & \\
\hline
\end{tabular}

Comments:
1. Units 1 and 2 are strongly mixed as in the Bw1 and Bw2 units at the $1520 \mathrm{~cm}$ profile.
2. Units 3 and 4 correlate to the $2 B k 1 b$ at $1520 \mathrm{~cm}$.
3. Unit 5 correlates to the $28 \mathrm{klb}$ at $1520 \mathrm{~cm}$.
4. Unit 6 correlates to the $2 B k 2 b$ at $1520 \mathrm{~cm}$. 


\begin{tabular}{|c|c|c|c|c|c|c|c|c|c|c|c|c|}
\hline $\begin{array}{l}\text { Site } \\
\text { Trench } \\
\text { Elevati } \\
\text { \% slope } \\
\text { Positin }\end{array}$ & $\begin{array}{l}\text { distance } \\
\text { on }\end{array}$ & $\frac{\frac{\text { RGFM1 }}{1520 \mathrm{~cm}}}{\frac{4960}{2}}$ & & & & $\begin{array}{l}\text { Coun } \\
\text { Loca } \\
\text { Pare } \\
\text { Vege } \\
\text { Big } \\
\text { Hor }\end{array}$ & $\begin{array}{l}\text { Ey } \\
\text { Eion } \\
\text { it Hate } \\
\text { tation } \\
\text { Saget } \\
\text { ref }\end{array}$ & erial & $\begin{array}{l}\text { Butte } \\
\text { Section } 14 \mathrm{~T} \\
\text { Slopewash } \\
\text { Mound: Ha log } \\
\frac{\text { Hintertat }}{\text { T4cm ton }}\end{array}$ & $\begin{array}{l}\text { T2N R3OE } \\
\text { geton: Inte } \\
\text { 8cm bottom }\end{array}$ & mound: $\mathrm{Cr}$ & ested wheatgrass, \\
\hline $\begin{array}{l}\text { Positio } \\
\text { Aspect }\end{array}$ & & $\begin{array}{l}\text { near ou } \\
\underline{\text { SW }}\end{array}$ & tcrop a & top & & & & & $74 \mathrm{~cm}$ top, 68 & $8 \mathrm{~cm}$ bottom & & \\
\hline Samp. & Depth & Horizon & Text. & Con & ist. & Lime & roots & Pores & Color & Structure & Boundary & $\%$ rock \\
\hline & & & & & & & 1. $f$ & tf & 1040 & I0nast & & \\
\hline$\frac{1}{2}$ & $0=10$ & OR & $\frac{1}{1}$ & Sin & 促 & es & 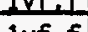 & L & Wins $4 / 2$ & fas sold & $\mathrm{E}$ & \\
\hline$\frac{2}{3}$ & $10-44$ & BW? & لـ & so & iss so & es & lytit & $=$ & 10YK $4 / 3$ & HIm sok & $\mathrm{CH}$ & \\
\hline 3 & $44-65$ & $2 \mathrm{Bk} 1 \mathrm{~b}$ & sil $/ 20$ & h & ss sn & es. & tyfif & $=$ & LOYR $5.5 / 3$ & $3 \mathrm{fm}$ sbk & CS & \\
\hline 4 & $65-100$ & $3 B k 1 b$ & sl & sh & so $s p$ & es & tvf.f & - & 10YR $5.5 / 3$ & $\operatorname{mass}_{\mathrm{D}]} / 2 \mathrm{mc}$ & cs & \\
\hline 5 & $100-118$ & $38 k 2 b$ & fsl & so & so po & es & - & - & 10YR $6 / 3.5$ & $\operatorname{mass}_{\mathrm{sbk}} / 2 \mathrm{fm}$ & & \\
\hline 6 & $118-127$ & Krot. & fs l & so & so no & es & $=$ & - & & massive & & \\
\hline 7 & $127-132$ & $38 \mathrm{k} 3 \mathrm{~b}$ & $s 1 / 20$ & h & & es & & - & 10YR $6 / 3$ & $\begin{array}{l}3 \mathrm{fm} \\
\mathrm{sbk} / \mathrm{abk}\end{array}$ & & \\
\hline $\begin{array}{l}\text { Comm } \\
1 . \\
2 . \\
3 . \\
4 . \\
5 . \\
6 .\end{array}$ & $\begin{array}{l}\text { Boundar } \\
\text { Bw1 and } \\
\text { through } \\
2 \text { Bklb } \\
\text { Krotovi } \\
\text { 2BkI an }\end{array}$ & $\begin{array}{l}\text { is } 40-50 \\
\text { ina exte } \\
\text { nd } 3 B \mathrm{~B} \text { u }\end{array}$ & 4 & & 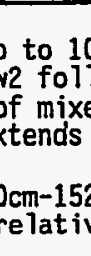 & to & r & $\begin{array}{l}\text { er s } \\
\text { Bk } \\
16\end{array}$ & $\begin{array}{l}\text { face of the } \\
\text { rizons. } 1- \\
\mathrm{cm} \text { where th }\end{array}$ & $\begin{array}{l}\text { mound. } \\
\text { 2mim clast } \\
\text { A. BW, }\end{array}$ & $\begin{array}{l}\text { of Bk are } \\
\text { sequence }\end{array}$ & $\begin{array}{l}\text { recognizable } \\
\text { is in-place. }\end{array}$ \\
\hline
\end{tabular}

\begin{tabular}{||c|c|c|c|c|}
\hline $\begin{array}{c}\text { Samp. } \\
\text { No. }\end{array}$ & Depth & Horizon & pH & EC \\
\hline 1 & $0-10$ & Bwl & 8.5 & 1.5 \\
\hline 2 & $10-44$ & $B w 2$ & 8.6 & \\
\hline 3 & $44-65$ & $28 \mathrm{k} 1 \mathrm{~b}$ & 7.8 & 9.6 \\
\hline 4 & $65-100$ & $3 \mathrm{Bk} 2 \mathrm{bl}$ & 7.7 & 20.5 \\
\hline 5 & $100-118$ & $3 \mathrm{Bk} 2$ & 7.7 & 28.2 \\
\hline 6 & $118-132$ & mixed & 7.7 & 46.3 \\
\hline
\end{tabular}

\begin{tabular}{|c|c|c|c|c|c|c|c|c|c|c|c|c|}
\hline \multirow{2}{*}{\multicolumn{2}{|c|}{$\begin{array}{l}\text { Site } \\
\text { Trench distance } \\
\text { Elevation } \\
\% \text { slope } \\
\text { Position } \\
\text { Aspect }\end{array}$}} & \multirow{2}{*}{\multicolumn{4}{|c|}{$\begin{array}{l}\frac{\frac{\text { RGFM1 }}{1645 \mathrm{~cm}}}{4960} \\
\frac{2}{\text { near outcrop at top }} \\
\text { SW }\end{array}$}} & \multirow{2}{*}{\multicolumn{3}{|c|}{$\begin{array}{l}\text { County } \\
\text { Location } \\
\text { Parent Material } \\
\text { Vegetation } \\
\text { Bia Sagebrush, } \\
\text { Hor. ref. }\end{array}$}} & \multirow{2}{*}{$\begin{array}{l}\text { Butte } \\
\text { Section } 1 \\
\frac{\text { Slopewash }}{\text { Mound: Ha }} \\
\text { Wintertat } \\
\text { Slcm top. }\end{array}$} & $\begin{array}{l}\text { T2N R30E } \\
\text { geton: In }\end{array}$ & err & ted \\
\hline & & & & & & & & & & $69 \mathrm{~cm}$ botto & & \\
\hline $\begin{array}{c}\text { Samp. } \\
\text { No. }\end{array}$ & $\begin{array}{c}\text { Depth } \\
\text { (cm) }\end{array}$ & Horizon & Text. & \multicolumn{2}{|c|}{ Consist. } & Lime & roots & Pores & $\begin{array}{l}\text { Color } \\
\text { (wet) }\end{array}$ & Structure & Boundary & $\%$ rock \\
\hline 1 & $0-10$ & $A$ & fs] & so & so no & es & $3 v f f$ & - & $10 Y 83 / 3$ & lfm_sbk & CS & \\
\hline 2 & $10-22$ & $B w 1$ & sil & sh & ss po & es & 1vf,f & - & 10YR $4 / 3$ & 3 fsbk (cgr & grw & \\
\hline 3 & $22-37$ & Bw2 & sil & sh & so po & es & $\begin{array}{c}1 v f, f \\
t-c\end{array}$ & $1 f, m$ & 10YR $4 / 3$ & $2 \mathrm{fm} \mathrm{sbk}$ & cs & \\
\hline 4 & $37-52$ & $\mathrm{Bk} 1$ & $\operatorname{sil} / 20$ & $h$ & ss & es & $1 v f f$ & tvf.f & $10 Y R 5 / 3$ & $3 \mathrm{fm}$ sbk & cs & \\
\hline 5 & $52-101$ & 2BkIb & 1 & $h$ & so po & es & tvf,f & $2 v f, f$ & 10YR $6 / 3$ & $\begin{array}{l}\operatorname{mass} / 2 m c \\
\text { pl }\end{array}$ & cs & \\
\hline 6 & $101-121$ & 2Bk2b & sI & sh & so po & es & $=$ & $E$ & 10YR 6/3 & $2 f-c$ sbk & & \\
\hline
\end{tabular}

Comments:

1. Intermound position, just outside the surface expression of the mound. Soils are undisturbed.

2. Surface horizons developed in undisturbed sediment.

pedestals, but is eroded away in much of the intermound areas.

3. The $2 B k 1 b$ is divided on the trench log into the $2 B k 1 b$ and $2 B k 2 b$. 


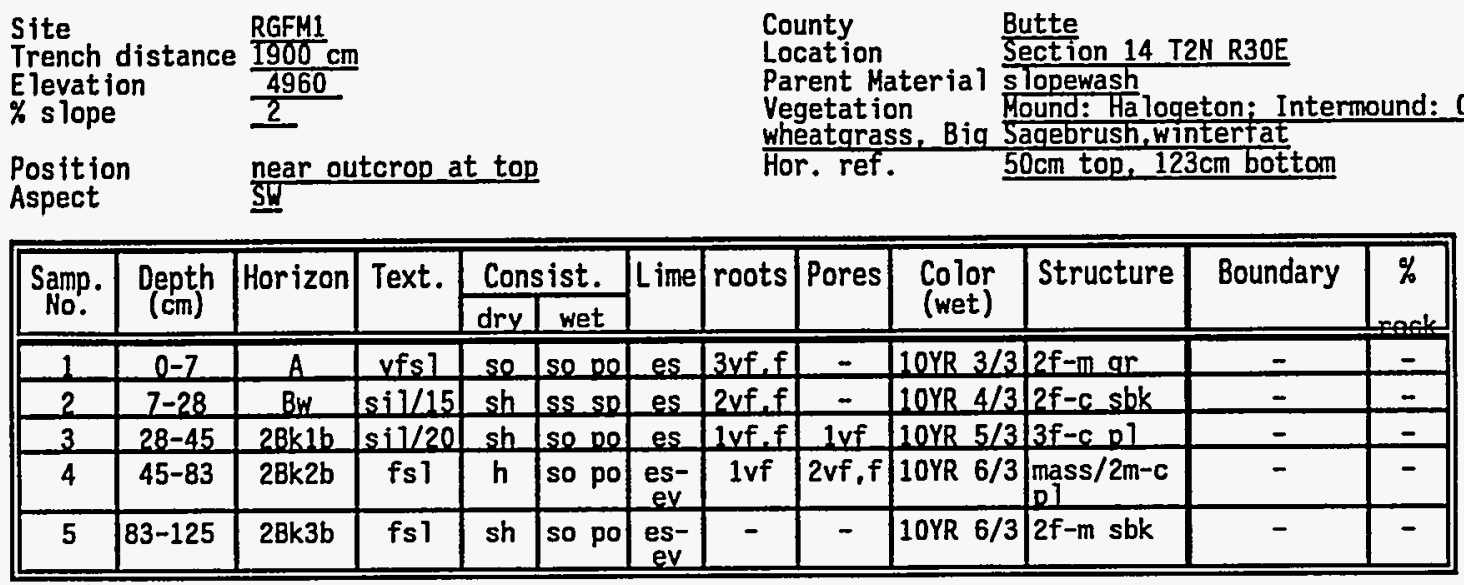

Remarks:

1. Intermound position.

2. The surface is $40 \%$ covered with basalt clasts up to $3 \mathrm{~mm}$ diameter.

3. Near vertical fractures extend from the 2Bk1 into the 28k2. Roots grow in the fractures. Planar orientation varies.

4. Basalt clasts $6 \times 8 \mathrm{~cm}$ and $5 \times 5 \mathrm{~cm}$ at $1820-1830$ at a depth of $66 \mathrm{~cm}$ from top.

5. Parent material is slopewash, w/increasing basalt sand in the $28 \mathrm{k} 2$ and $28 \mathrm{~B} 3$.

\begin{tabular}{|c|c|c|c|c|c|c|c|c|c|c|}
\hline \multirow{2}{*}{ Samp. } & \multirow{2}{*}{$\begin{array}{c}\text { Depth } \\
(\mathrm{cm})\end{array}$} & \multirow[t]{2}{*}{ Horizon } & \multicolumn{3}{|c|}{ Particle size } & \multirow{2}{*}{$\begin{array}{l}\text { Text. } \\
\text { c.lass }\end{array}$} & \multirow{2}{*}{$\begin{array}{l}\text { sat \% } \\
\text { water }\end{array}$} & \multirow[t]{2}{*}{$\mathrm{pH}$} & \multirow{2}{*}{$\underset{\text { (mv) }}{E C}$} & \multirow{2}{*}{$\begin{array}{c}\mathrm{CaCO} 3 \\
\%\end{array}$} \\
\hline & & & $\%$ sand & $\%$ silt & \% clay & & & & & \\
\hline 1 & $0-7$ & $\bar{A}$ & 48.8 & 35.6 & 9.6 & sl & 4.9 & 7.6 & 2.4 & 9.07 \\
\hline 2 & $7-28$ & $B w$ & 31.9 & 38.8 & 23.8 & 1 & 39.7 & 7.8 & 1.4 & 14.8 \\
\hline 3 & $28-45$ & $28 \mathrm{k} 1 \mathrm{~b}$ & 48.4 & 39.9 & 7.6 & 1 & 48.1 & 8.0 & 1.7 & 16.8 \\
\hline 4 & $45-83$ & $28 \mathrm{k} 2 \mathrm{~b}$ & & & & & 46.6 & 8.2 & 0.3 & 10.2 \\
\hline 5 & $83-125$ & $28 \mathrm{k} 3 \mathrm{~b}$ & & & & & 48.7 & 8.4 & 0.47 & \\
\hline
\end{tabular}




\section{Appendix C}

Site Location and Surficial Characteristics 


\section{Appendix C}

\section{Site Location and Surficial Characteristics}

\section{Mound: 8MFM2}

Location: NW 1/4, NE 1/4, Section 7, T4N, R29E

Parent Material: Reworked loess over fan gravels

Site description: High geomorphic position on the center of the fan, $1 / 3$ of the way from the apex, af3 surface (Bull Lake age) (Scott, 1982). Trench is on an interfluve with a well-defined drainage on the north side.

Slope (\%): 2

Diameter: $13.5 \mathrm{~m}$

Nearest Neighbors: $\approx 15 \mathrm{~m}$, mounds are aligned downslope along an interfluve.

Vegetation Mound: Sagebrush species (Artemesia sp.), Winterfat (Ceratoides lanata)

Vegetation Intermound: Sagebrush (Artemesia sp.), Winterfat (Ceratoides lanata), Prickly Pear Cactus (Opuntia polycantha).

Vegetation general comments: The vegetation species are the same on the mounds and intermounds. The height and density of vegetation is increased on the mounds vs intermounds. More sagebrush is dead on the mounds than the intermounds.

Surface morphology mounds: Very similar to intermound surfaces, but with evidence of old mammal burrows. Very few fresh burrows were observed in this area.

Surface morphology intermounds: Rocky (mostly clasts $<10 \mathrm{~cm}$ ), crusted surface soils, some development of biogenic crusts.

Other: Mound edges are very diffuse and difficult to delineate. 
Mound: 8MFM4

Location: SE 1/4, NE 1/4, Section 6, T4N, R29E

Parent Material: Reworked loess over fan gravels

Site description: Low geomorphic position on the north flank of the fan, half way down from the apex, af 2 surface (Pinedale age). Trench is on a smooth slope with no well-defined drainages.

Slope (\%): 1.5

Diameter: $12 \mathrm{~m}$

Nearest Neighbors: not measured. The af 2 surface has a lower density of mounds than the af3 surface.

Vegetation Mound: Sagebrush species (Artemesia sp.), Winterfat (Ceratoides lanata), other unidentified native species

Vegetation Intermound: Sagebrush (Artemesia sp.), Winterfat (Ceratoides lanata), Prickly Pear Cactus (Opuntia polycantha), other unidentified native species.

Vegetation general comments: The vegetation species are the same on the mounds and intermounds. The main difference is the increased height and density of sagebrush on the mounds. More sagebrush is dead on the mounds than the intermounds.

Surface morphology mounds: Very similar to intermound surfaces, but may have signs of old mammal burrows. Fresh burrows were observed on most af 3 surface mounds.

Surface morphology intermounds: Rocky (mostly clasts $<10 \mathrm{~cm}$ ), crusted surface soils, some development of biogenic crusts.

Other: Mound edges are very diffuse and difficult to delineate. 


\section{Mound: BLRM2}

Location: NW 1/4, Section 5, T2N, R29E

\section{Parent Material: Alluvial terrace, Qa}

Site description: Closest basalt outcrop is $0.6 \mathrm{~km}$ west, river channel is $0.2 \mathrm{~km}$ north. A manmade canal with elevated berms is $40 \mathrm{~m}$ away, and a small gravel road is $25 \mathrm{~m}$ away.

\section{Slope (\%): 0}

\section{Diameter: $12.5 \mathrm{~m} \times 13 \mathrm{~m}$}

Nearest Neighbors: $30 \mathrm{~m}$ and $58 \mathrm{~m}$

Vegetation Mound: Big Sage (Artemesia Tridentata), Green Rabbitbrush (Chrysothamnus viscidiflonus), Prickly Pear Cactus (Opuntia polycantha), False Globe Mallow, Annual mustard species

Vegetation Intermound: Big Sage (Artemesia Tridentata), Green Rabbitbrush (Chrysothamnus viscidiflorus), Needle and thread grass (Stipa comata), Great Basin Wildrye (Elymus cinereus), Indian Rice Grass (Oryzopsis hymenoides), Prickly Pear Cactus (Opuntia polycantha), Desert Paintbrush (Castelleja angustifolia) and other wildflower species.

Vegetation general comments: The density and size of Big Sage, mustard species, and Green rabbitbrush on the mounds is noticeably greater than in the intermounds. The number of plant species is greater in intermound areas. The spring of 1993 was quite wet, and many species of annual and perennial wildflowers emerged and bloomed. Spring, 1994 was dry and vegetation was sparse.

Surface morphology mounds: $30-50 \%$ alluvial gravels up to $3 \mathrm{~cm}$ diameter. Anthills of 1-2 mm gravels on mound flanks.

Surface morphology intermounds: well-developed gravel pavement, up to $90 \%$ density in nonvegetated areas. Common anthills. Small, unstabilized sand dunes surrounding low shrubs and other dense vegetation.

Other: A large ( $\approx 50 \times 70 \mathrm{~cm}$ ), rounded basalt boulder sits on the intermound surface near the trench. The boulder was probably transported by a glacial-outburst flood. 


\section{Mound: BLRM4}

Location: NW 1/4, NW 1/4, Section 33, T3N, R29E

Parent Material: Alluvial terrace, Qb

Site description: Closest river channel is $0.4 \mathrm{~km}$ west, US 20 is $\approx 0.6 \mathrm{~km}$ east. BLRM4 is in the center of a meander scar.

Slope (\%): 0

Diameter: $12 \mathrm{~m} \times 7.5 \mathrm{~m}$. Long diameter oriented N85W.

Nearest Neighbors: $24 \mathrm{~m}$ and $24 \mathrm{~m}$. Both on opposite sides of meander channel.

Vegetation Mound: Big Sage (Artemesia Tridentata) 50\% dead, Green Rabbitbrush (Chrysothamnus viscidiflorus), Prickly Pear Cactus (Opuntia polycantha), False Globe Mallow (Sphaeralcea sp.), Needle and thread grass (Stipa comata), Halogeton.

Vegetation Intermound: Sagebrush species (Artemesia sp.), Green Rabbitbrush (Chrysothamnus viscidiflorus), Needle and thread grass (Stipa comata), Indian Rice Grass (Oryzopsis hymenoides), Prickly Pear Cactus (Opuntia polycantha), Buckwheat (Eriogonum microthecum), Desert parsley (Lomatium dissectum), other wildflower species.

Vegetation general comments: Sagebrush was short, typically $10 \mathrm{~cm}$ in height with taller flower stalks. Big Sage on the mounds was considerably taller, but $50 \%$ of it appeared dead.

Surface morphology mounds: $30-50 \%$ alluvial gravels up to $3 \mathrm{~cm}$ diameter. Anthills of 1-2 mm gravels on mound flanks.

Surface morphology intermounds: well-developed gravel pavement, up to $90 \%$ density in nonvegetated areas. Common anthills. Small, unstabilized sand dunes surrounding low shrubs and other dense vegetation. 


\section{Mound: RWMCM1}

Location: center, SW 1/4, Section 18, T2N, R29E

Parent Material: Loess over basalt. Mapped as el2, Middle to Upper Pleistocene loess, by Scott (1982).

Site description: Located on a short slope with bedrock outcrop just upslope, and flattening near the lowest point of the mound. The nearest road is $\mathbf{1 0}$ meters from the toe of the slope.

Slope (\%): $<5$

Height: $0.5 \mathrm{~m}$

Diameter: $12.2 \mathrm{~m}$

Nearest Neighbors: not measured

Vegetation Mound: Big Sage (Artemesia sp.), Green Rabbitbrush (Chrysothamnus viscidiflonus), Prickly Pear Cactus (Opuntia polycantha)

Vegetation Intermound: Sagebrush species (Artemesia sp.), Green Rabbitbrush (Chrysothamnus viscidiflorus), Winterfat (Ceratoides lanata), Prickly Pear Cactus (Opuntia polycantha), Squirreltail grass (Sitanion hystrix), Indian ricegrass (Oryzopsis hymenoides).

Vegetation general comments: Big sage is larger on the mound than on the intermound areas.

Surface morphology mounds: Similar to intermounds, fewer basalt clasts, fresh and old burrow piles evident.

Surface morphology intermounds: Soil/vegetated surface, basalt rocks, especially upslope closer to outcrops. Soils have polygonal fracture patterns from freeze/thaw processes. Some small $(\approx 10 \mathrm{~cm}$ diameter) sorted stone circles around the polygonal cracks.

Other: Mound edges are diffuse and grade into the intermound. The upslope side of the mound has no topographic delineation, the toe of the mound is well defined. 
Mound: IPM2

Location: NW 1/4, NW 1/4, Section 29, T2N, R29E

Parent Material: Loess over basalt

Site description: Shallow basin formed within low basalt ridges. Scott (1982) mapped the area as el2, Upper and Middle Pleistocene silt and sandy silt, up to 3 m thick.

Slope (\%): $<1$

Diameter: $11.5 \mathrm{~m}$

Nearest Neighbors: not measured.

Vegetation Mound: Sagebrush species (Artemesia sp.), Squirreltail grass (Sitanion hystrix), annual mustard species, phlox (Phlox sp.).

Vegetation Intermound: Sagebrush (Artemesia sp.), Winterfat (Ceratoides lanata), Prickly Pear Cactus (Opuntia polycantha), other unidentified native species.

Vegetation general comments: Striking increase in annual mustard species on the mounds.

Surface morphology mounds: Very similar to intermound surfaces, with evidence of mammal burrows.

Surface morphology intermounds: Crusted surface soils, some development of biogenic crusts.

Other: Mound edges are very diffuse and difficult to delineate. 
Mound: RGFM1

Location: NW 1/4 NW 1/4, Section 14, T2N, R30E

Parent Material: Loess and slopewash over basalt

Site description: Upper section of a broad bowl oriented to the southwest. Basalt outcrops around the top of the bowl, and within $40 \mathrm{~m}$ of the trench.

Slope (\%): 2

Diameter: $11 \mathrm{~m} \times 14 \mathrm{~m}$, long dimension was N120E.

Nearest Neighbors: $12 \mathrm{~m}$ and $29.5 \mathrm{~m}$

Vegetation Mound: Halogeton

Vegetation Intermound: Wheatgrass species (Agropyron sp), Sagebrush (Artemesia sp.), Winterfat (Ceratoides lanata), Milkvetch (Astragalus sp.) Prickly Pear Cactus (Opuntia polycantha).

Vegetation general comments: Wheatgrass is the dominant species in the intermound areas. It was planted in the mid-1900's to revegetate a firescar area. It is unclear if the area was plowed or disced prior to drilling seeds. Halogeton is the only vegetation on the mounds, and has spread several meters into the intermound vegetation.

Surface morphology mounds: Smooth bare soil. Very few basalt clasts found on mound surfaces, none on RGFM1. Soil shows weak development of polygonal cracking after a rain. Many animal burrows.

Surface morphology intermounds: Mainly smooth soil surface except where vegetated. Soil pedestals up to $8 \mathrm{~cm}$ have formed around wheatgrass clumps. Basalts ranging in size from a few $\mathrm{cm}$ to $40 \mathrm{~cm}$ are frequent, the density varies depending on proximity to outcrops, and perhaps depth to bedrock.

Other: Basalt boulders at the surface lie at all orientations with respect to their most stable configuration. Calcium carbonate coats are exposed at various orientations, and lichen are growing on exposed sides which used to be buried. The disoriented boulders are reasonable evidence of discing, but they also occur on very thin soils near outcrops. 


\section{MF!}

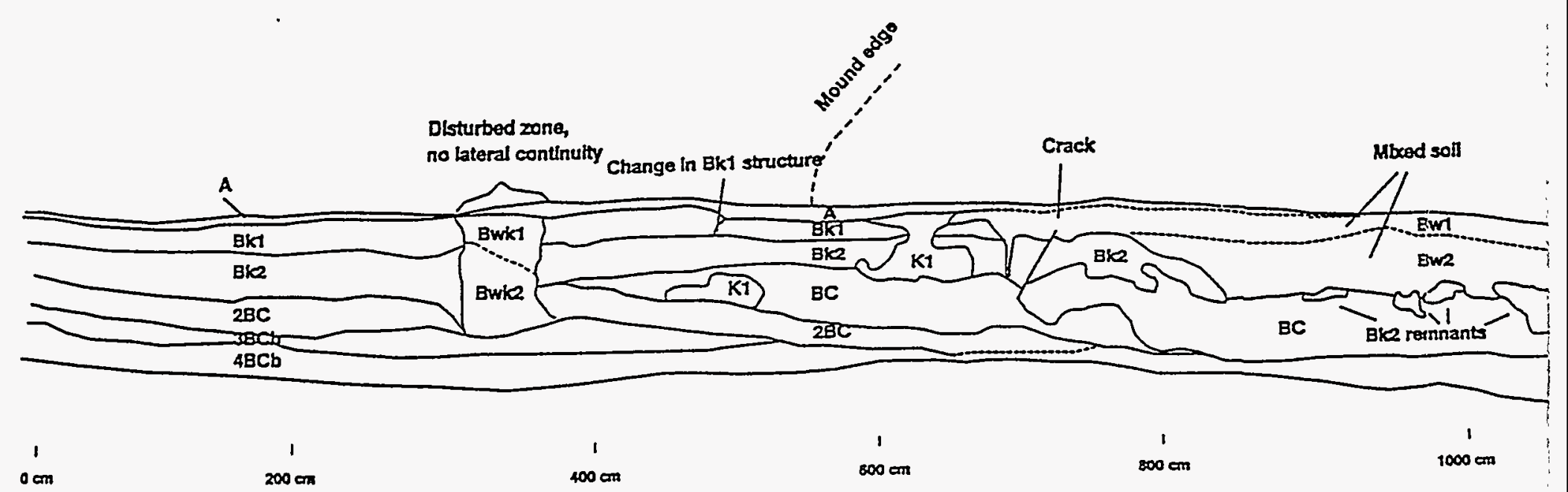

Figure $5 \quad$ Profile log of 8MFM2 


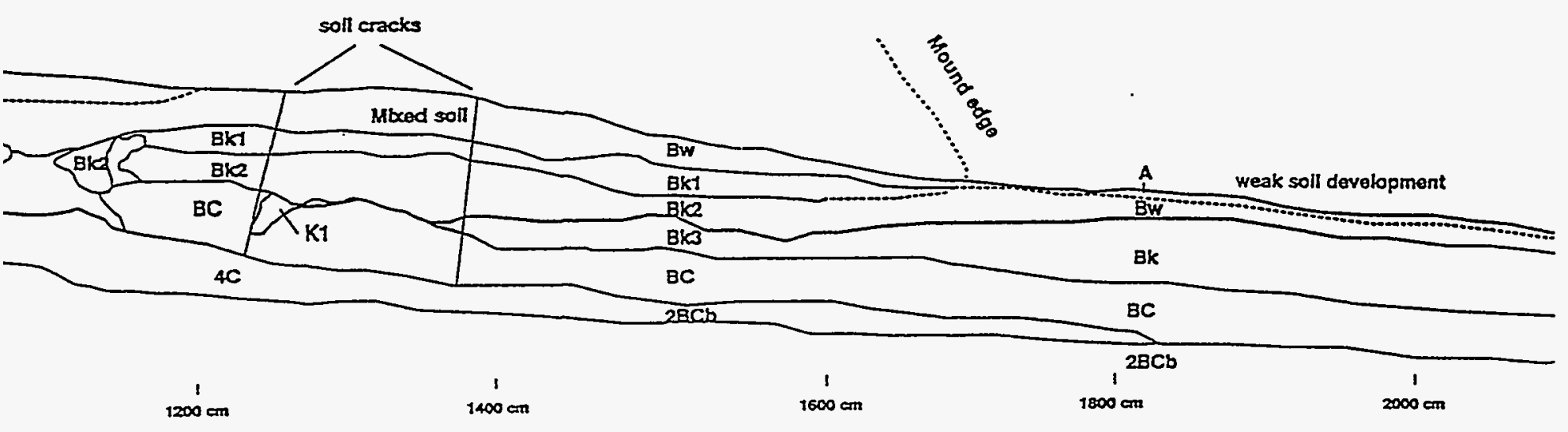



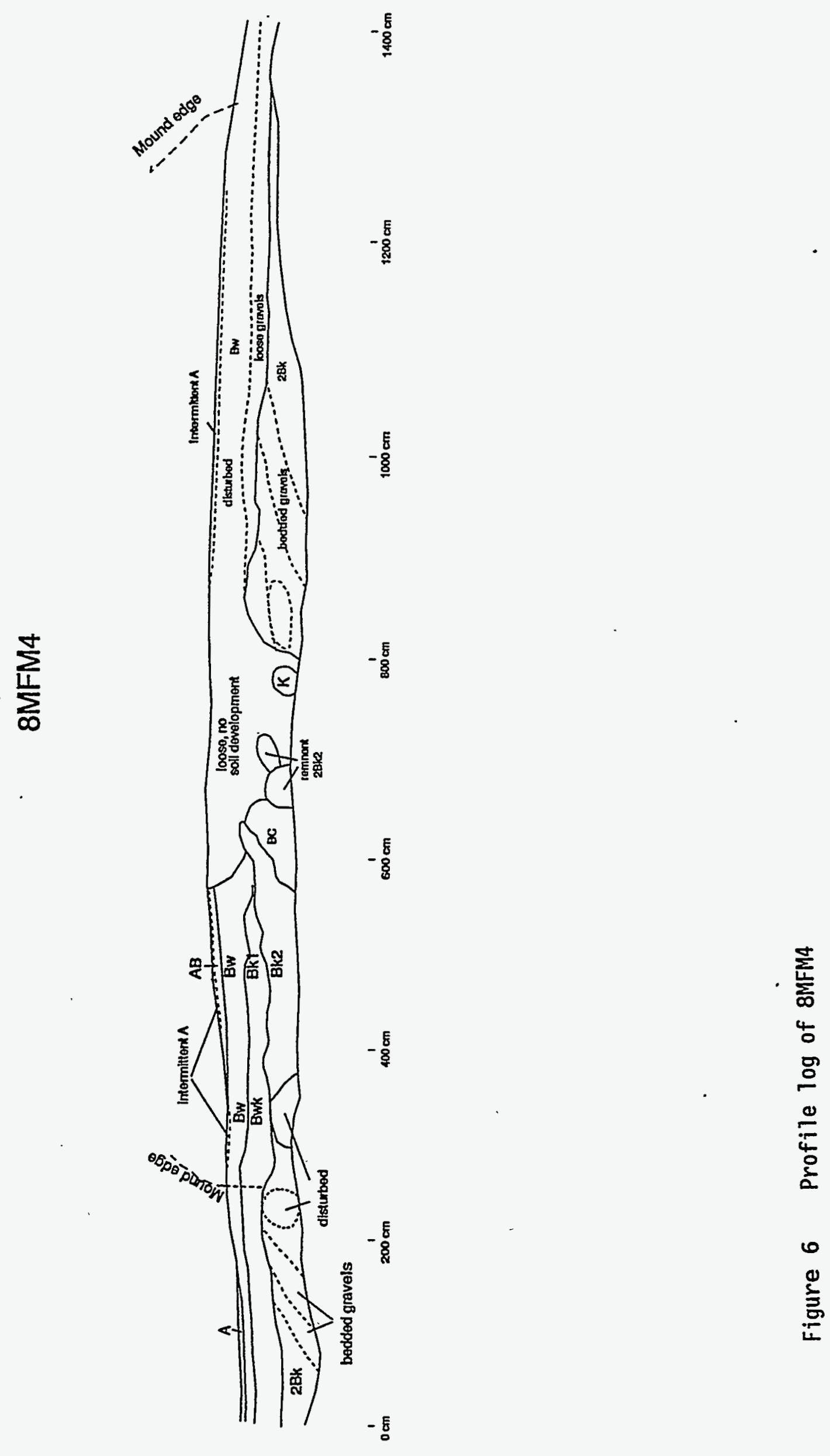


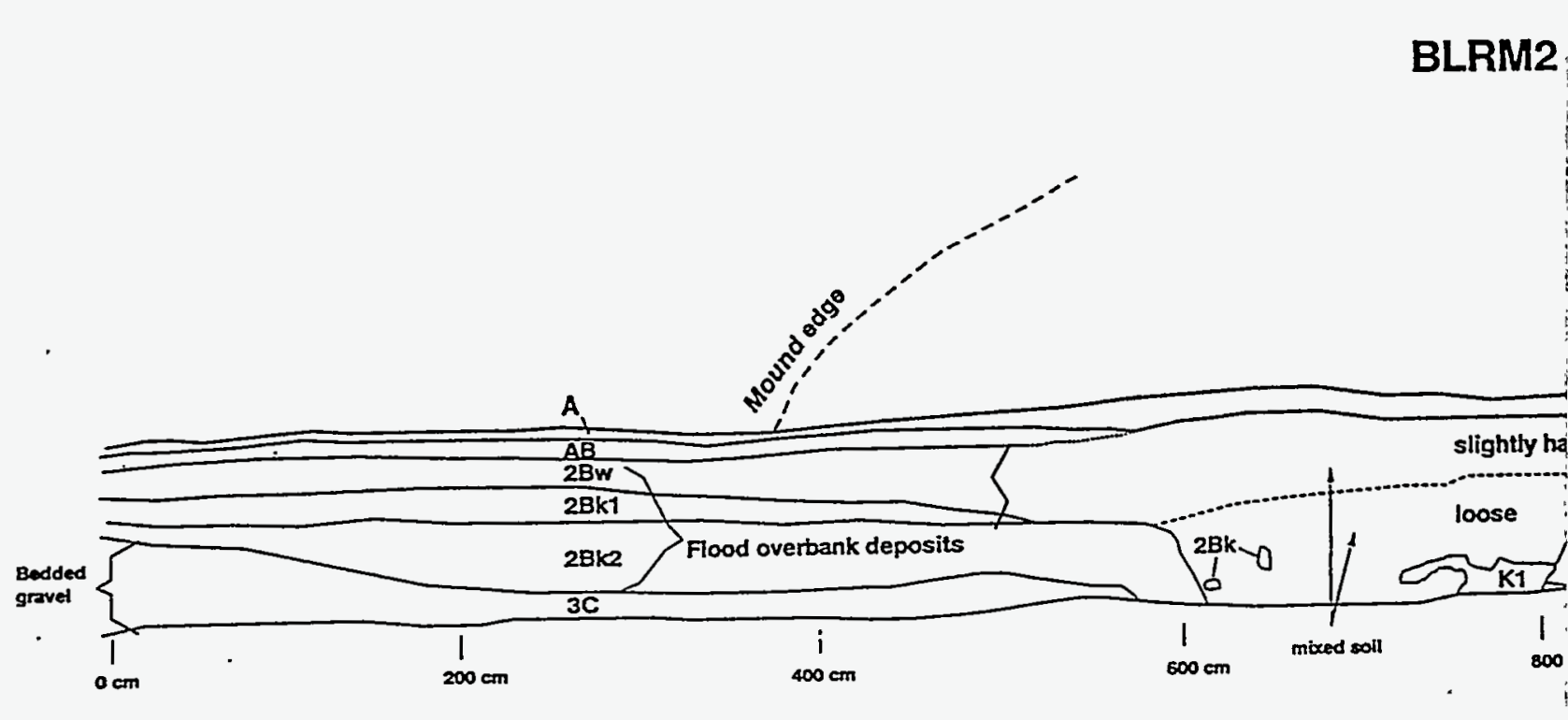

Figure 8 Profile $10 \mathrm{~g}$ of BLRM2 


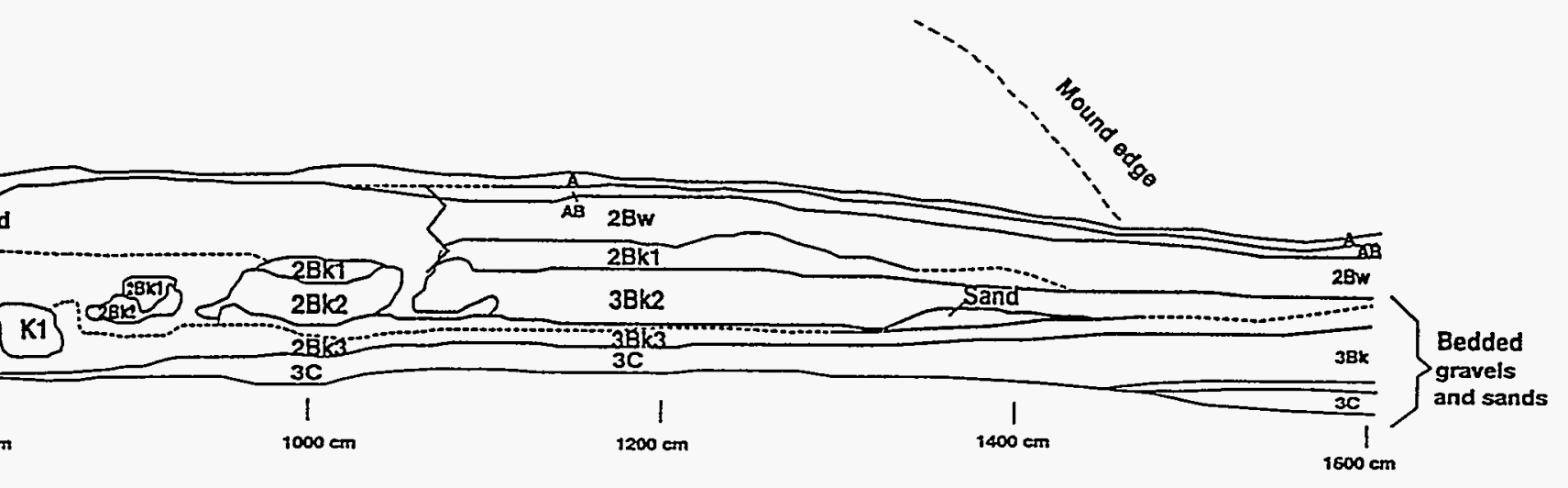




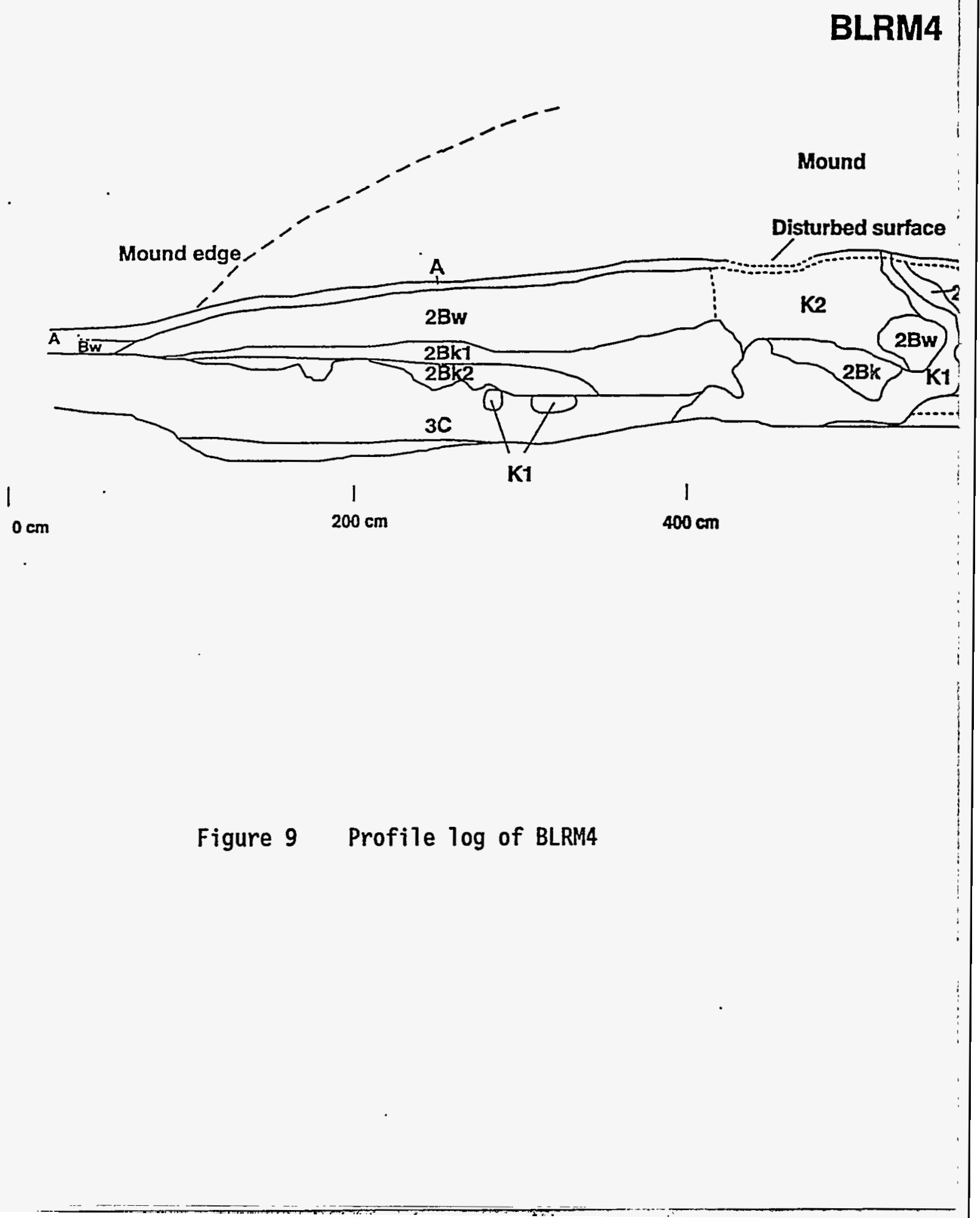




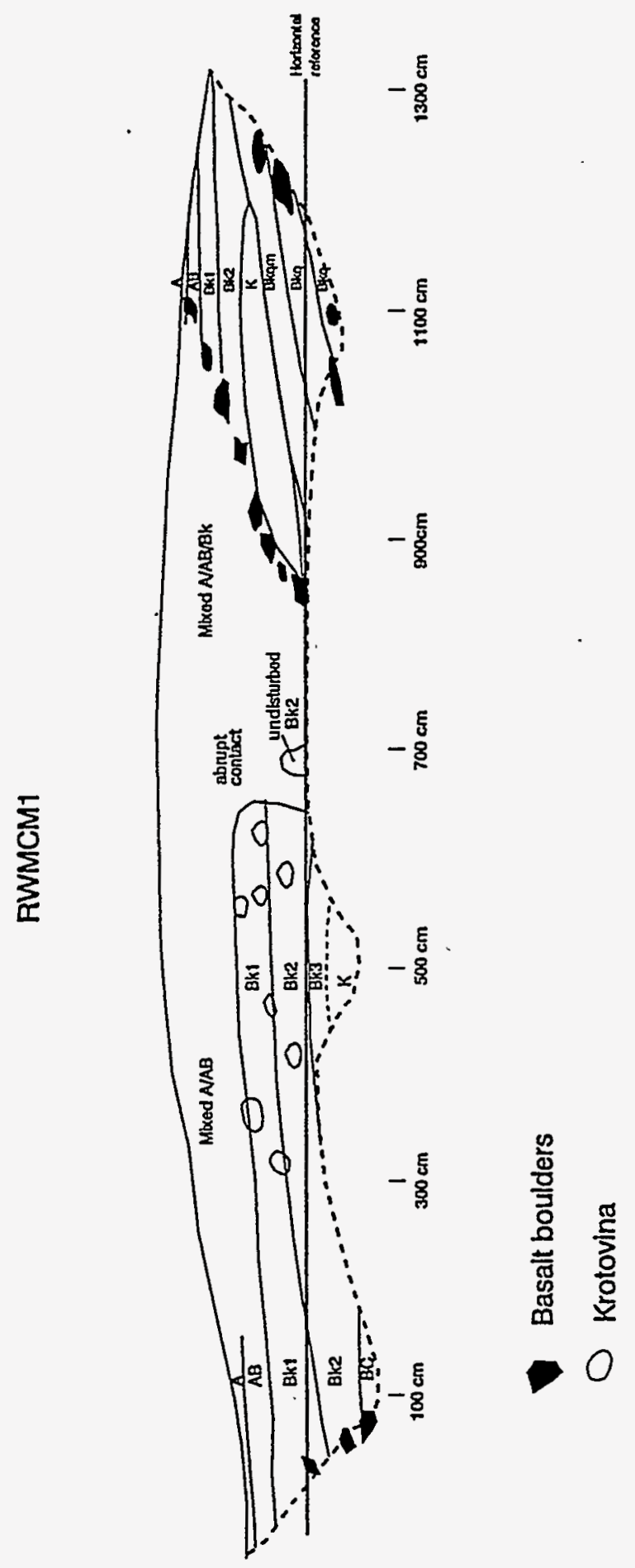

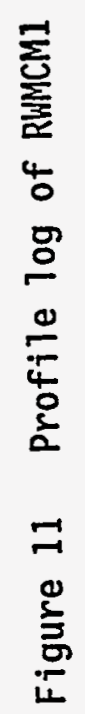




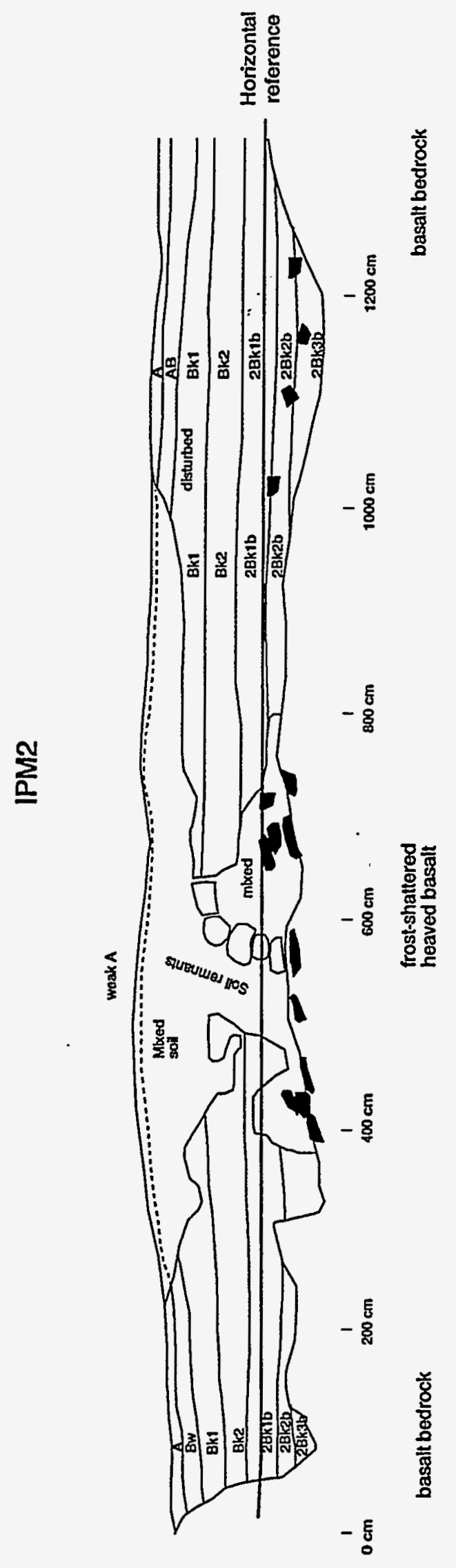

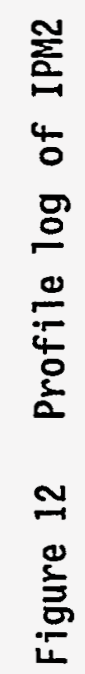




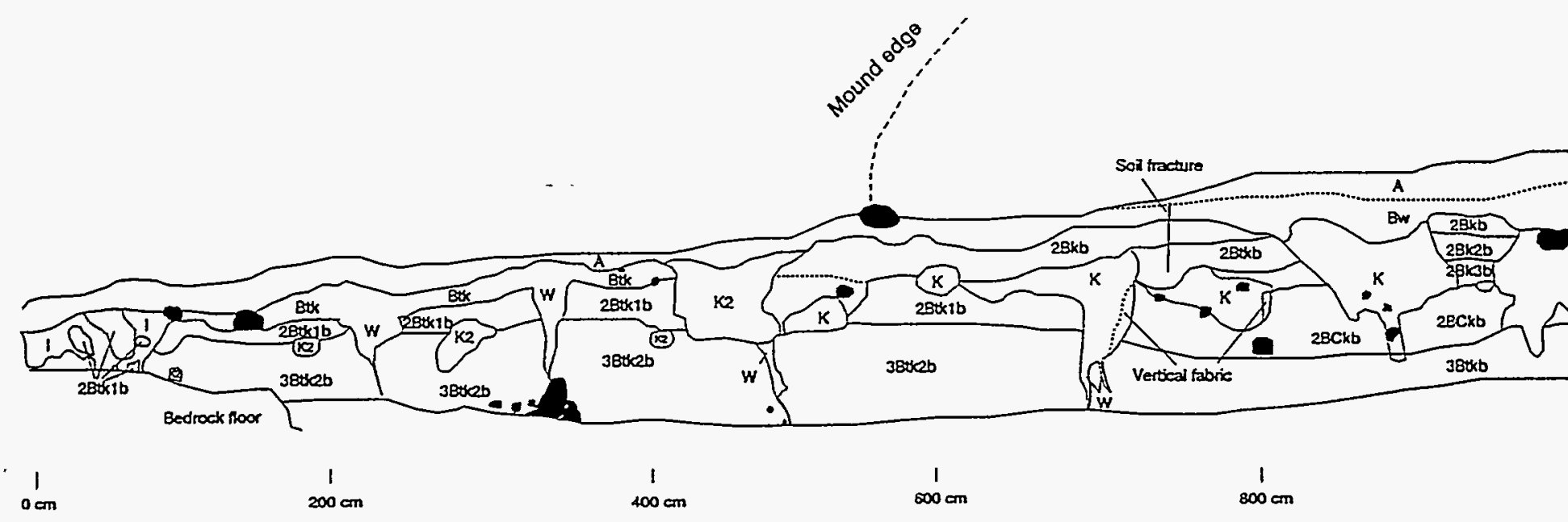

Figure 14 Profile log of RGFM1 
